Historic, Archive Document

Do not assume content reflects current

scientific knowledge, policies, or practices. 



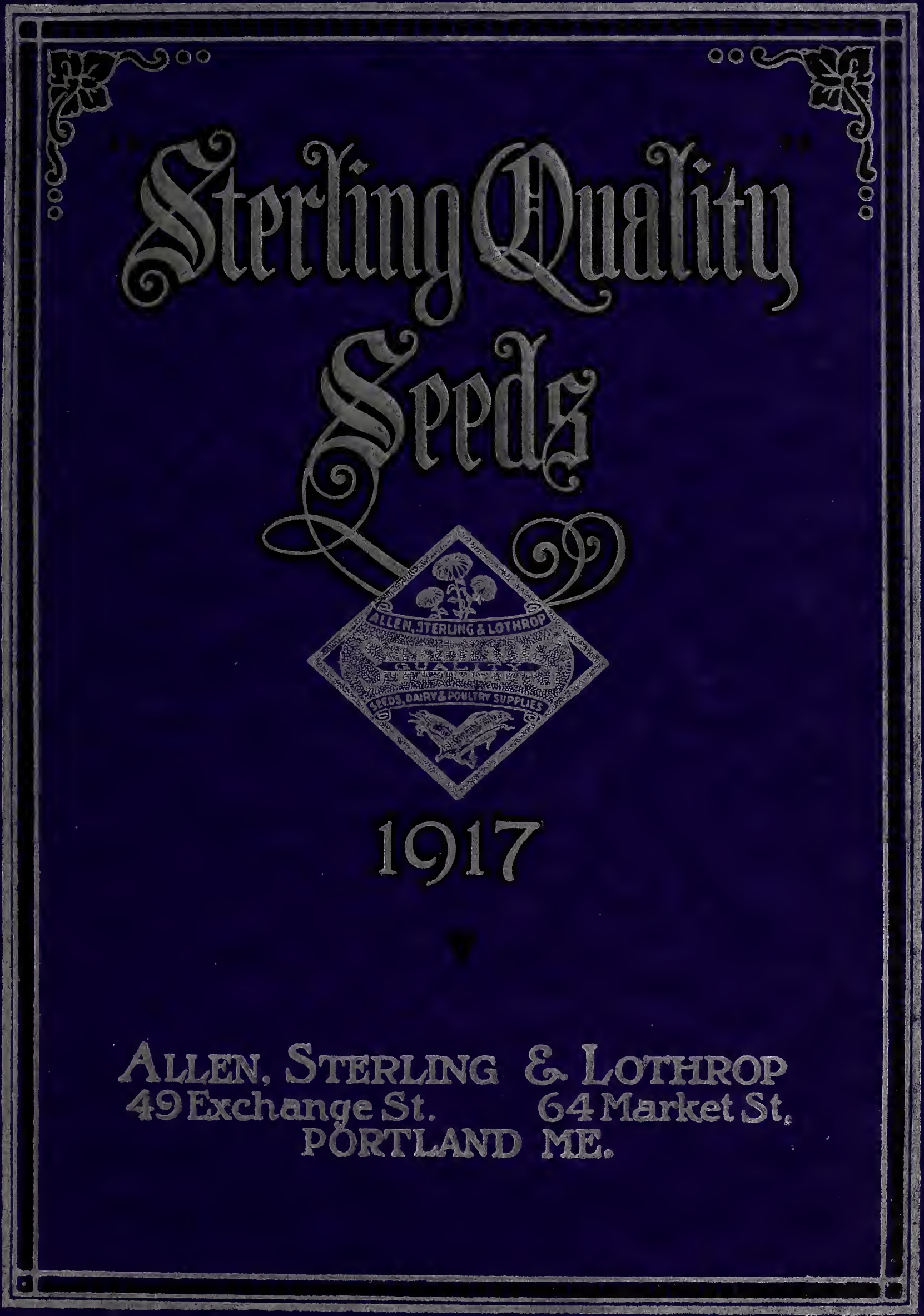




\section{Information and Suǵgestions to Customers}

The world is now facing a SCARCITY OF FOOD PRODUCTS. This is realized more definitely each day as farm products soar to the highest prices eoer known. Market gardeners, farmers, and food producers in general cannot supply all that will be needed this year. The National and State Experiment Stations are urging a oery heavy planting; but one serious drawback to this is the scarcity of a great many of the ordinary varieties of seed. The demand for seed will probably exceed the supply. If you delay ordering you are taking the chance of not getting half your needs. We are stating to you the true conditions in a spirit of co-operation. Write us at once, sending us your order, and we will use every effort to fill same completely with our "Sterling Quality" Seeds.

Caution

g "Sterling Quality" Seeds are the highest grade obtainable and intended for the particular market gardener, florist and individual. We do not sell to dealers. "Sterling Quality" Seeds can be procured only directly from us.

Free Delivery $\quad$ I We deliver "Sterling Quality" flower and vegetable seeds free to any address in the United States when purchased by the packet, ounce, half pound and pound.

Orders $\quad$ Should be written on our order sheet or on a blank sheet separate from letter, preferably in ink. Be sure to sign your name and give your address.

Remittances ICan be safely sent by Bank Check, Post Office Order, Registered Letter or Express Money Order. Postage Stamp remittances taken in amounts less than $\$ 1.00$.

New Customers I Will kindly remit the amount with their orders, or name business references, as customary before opening new accounts.

Market

Gardeners

I Farmers' Clubs and Institutions purchasing Seeds in large quantities should write for special prices. Send a list of quantities and varieties required and we will return list promptly with quotations.

No Charge

for Packing

Telephone

Orders

q But bags billed at cost. If returned in good condition free of expense, they will be credited at price charged.

Non-Warranty

I Will be given immediate attention. Call Portland 625.

I There are many contingencies constantly arising to prevent the best seeds from giving satisfaction. We aim to supply only the best quality of seeds and to be as represented; but it is impossible to guarantee seeds under all circumstances. We give no warranty, expressed or implied, as to description, quality or productiveness of any seeds, bulbs or plants, and will not in any way be responsible for the crop. If the purchaser does not accept the goods on these terms, they are at once to be returned.

Prices quoted in our Catalogue are subject to change without notice

\section{ALLEN, STERLING \& LOTHROP PORTLAND, MAINE}




\section{GENERAL LIST OF SELECT VEGETABLE SEEDS}

WE PREPAY POSTAGE OR EXPRESS GHARGES ON ALL SEEDS ORDERED BY THE PACKET, OUNCE, QUARTER POUND OR POUNDS.

\section{ASPARAGUS}

Sow the seeds thinly in April or May in rows one foot apart and one inch deep; when the plants are well up, thin to 3 or 4 inches apart in the rows.

The next season plant in rows 3 feet apart and 1 foot in the rows, covering the plants about 6 inches.

The soil should be thoroughly manured and trenched, at least 2 feet.

One ounce will sow 50 feet of drill.

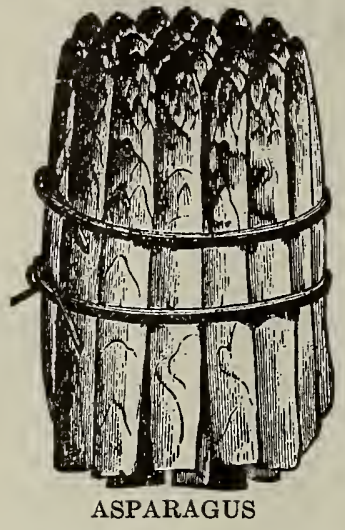

Columbian Mammoth. A large white variety of fine flavor. Pkt 5c., oz. 10c., 2 oz. 15c., 1/4 lb. 25 c.

Conover's Colossal. A standard sort of large size and excellent quality. Pkt. 5c., oz. 10c., 1/4 lb. $20 \mathrm{c}$.

Early Giant Argenteuil. An early variety, being ten days earlier than the Palmetto, of larger size and superior flavor. One of the finest sorts in cultivation Pkt. 5c., oz. 10c., 2 oz. 15c., 1/4 lb. 30c.

Palmetto. A standard light green variety. Pkt. 5c., oz. 10c., 2 oz. 15 c., $1 / 4$ lb. 20 c.

\section{BEANS, Dwarf}

Plant in light, warm soil in the spring, when danger from frost is past, in drills from 2 to 3 feet apart, covering about 2 inches deep. Sow every two weeks for a succession. Cultivate frequently until they blossom, but only when dry.

One quart is sufficient for 100 feet of drill; $11 / 4$ bu. for 1 acre.

Pkts. 10c. each, prepaid. If other quantities are wanted by mail, add at the rate of $5 c$. per qt., half pks. and half bus. at pk. and bu. rates.

\section{BEANS, Green Podded}

Bountiful. Early and prolific, flat green pods, cook tender. $1 / 2$ pt. 10 c., pt. 20 c., qt. 35 c., 2 qts., 65 c., $1 / 2$ pk. $\$ 1.30, \mathrm{pk}$., $\$ 2.50$.

Burpee's Improved Bush Lima. Compared with Burpee's Bush Lima, both pods and beans are very much larger, while the beans, either green or dry, are nearly twice as thick and ready to market eight to ten days earlier. Pkt. 10c., pt. 20c., qt. 35c., $1 / 2$ pk. $\$ 1.15$, pk. $\$ 2.50$.

Goddard or Boston Favorite. Fine shell bean. Pods and beans similar in color, larger and longer than the Dwarf Horticultural. Very prolific. I/2 pt. 10c., pt. 20 c., qt. 35 c., 2 qts. 70 c., $1 / 2$ pk. $\$ 1.30$, pk. $\$ 2.50$.
FRENCH HORTICULTURAL DWARF.

This is a bean of the Horticultural type. Pods remarkably large, many containing seven beans, beautifully splashed with bright crimson. Never spots or rusts. The vines are vigorous and productive, inclined to send out runners, but do not affect the bean in any way. Very popular with market gardeners. $1 / 2$ pt. 20 cts., pt. 35 cts., qt. 55 cts., $1 / 2$ pk. $\$ 1.75$, pk. $\$ 3.00$.

Dwarf Horticultural. A fine shell bean with long green pods, very productive. $1 / 2$ pt. $10 \mathrm{c}$., pt. $20 \mathrm{c}$., qt. $35 \mathrm{c}$., 2 qts. 70 c., I $/ 2$ pk. $\$ 1.30$, pk., $\$ 2.50$.

Burpee's Stringless Green Pod. Combines unusual hardiness, extreme earliness and wonderful productiveness. The pods are tender, brittle and of the finest flavor; always entirely stringless. $1 / 2$ pt. $10 \mathrm{c}$., pt. 20 c., qt. 35 c., 2 qts. 70 c., t/2 pk. $\$ 1.30$, pk. $\$ 2.50$.

Keeney's Stringless Green Refugee. The plant grows to a large size and is very productive. The pods are round, 5 to 6 inches long, medium green in color and are perfectly stringless at all stages of development, even when the beans are old enough to shell. Grop failed.

Long Yellow Six Weeks. A leading market sort, long green pod, I $/ 2$ pt. 10 c., pt. 20 c., qt. $35 \mathrm{c}$, 2 qts. 65 c., I $/ 2$ pk. $\$ 1.25$, pk. $\$ 2.50$.

Low's Champion. Very early, absolutely stringless, exquisite flavor, very productive. One of the finest snap beans, an excellent shell bean, and is of splendid flavor when cooked dry. $1 / 2$ pt. 10c., pt. 15 c., qt. 30 c., 2 qts. 65 c., $1 / 2$ pk. $\$ 1.00$, pk. $\$ 1.75$.

Red Kidney. Fine for baking and a good shell bean. Price quoted on application.

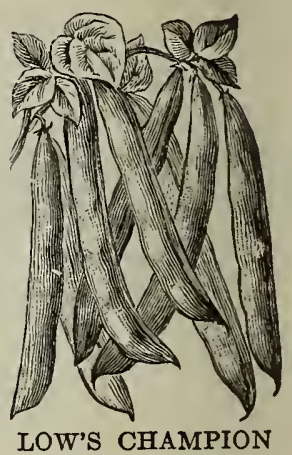

BUSH BEAN
Golden California Pea. The best sort for baking; a very hardy and prolific variety, having the richness and flavor not found in other varieties. Price quoted on application.

Snowflake Pea. The best small white pea bean, early and productive. Price quoted on application.

Yellow-Eyed (Old-fashioned). Very productive. Fine for baking, extensively grown as a dry bean for winter use. Price quoted on application. 


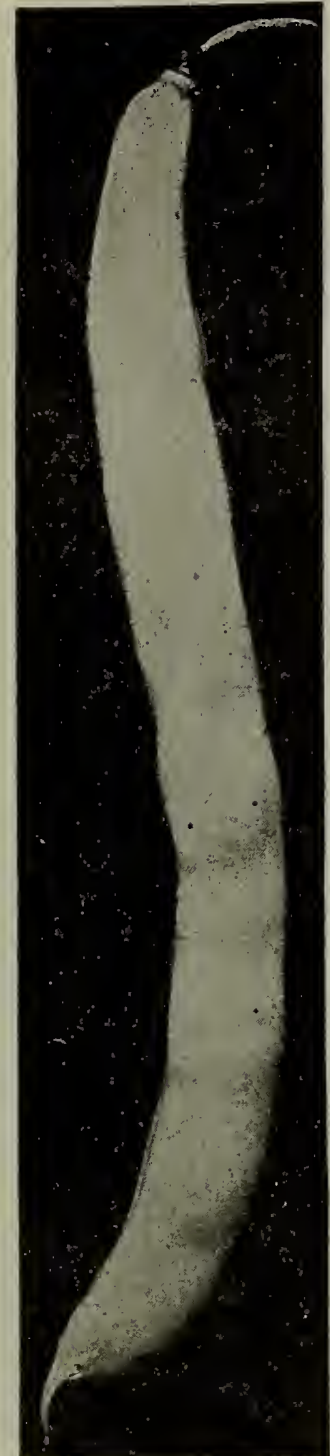

SURE CROP STRINGLESS WAX BEAN

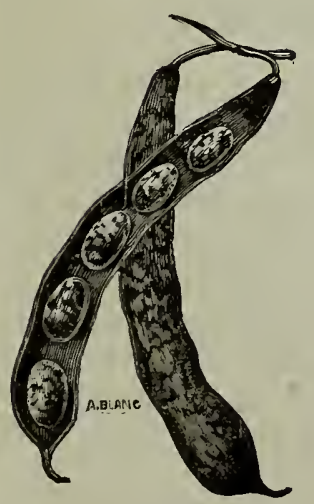

LONDON HORTICULTURAL POLE BEAN

\section{BEANS, Wax Podded (Dwarf)}

Black Wax, Pencil Pod. Pods are long, pencil like, tender and brittle. In color they are a rich, dark yellow, hardy and productive. $1 / 2$ pt. $15 \mathrm{c}$., pt. 25c., qt. 40c.: $1 / 2$ pk. $\$ 1.50$, pk. $\$ 3.00$

Burpee's Kidney Wax. More productive than Wardwell's Kidney Wax; longer pods which are entirely stringless and are much finer quality. Free from blight and rust. $1 / 2$ pt. 15 c., pt. 25 c., qt. 50 c., 2 qts. 90 c., $1 / 2$ pk. $\$ 1.75$, pk. $\$ 3.25$.

Improved Golden Wax. An early, hardy variety, flat, golden-yellow pods. 1/2 pt. 15c., pt. 25c., qt. 40c., $1 / 2 \mathrm{pk}$. $\$ 1.50$, pk. $\$ 3.00$.

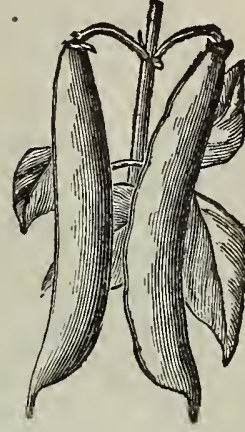

KIDNEY WAX BEAN

Sure Crop Stringless Wax. A wax-podded variety of remarkable growth and productiveness. Plants hardy and prolific; pods $71 / 2$ inches long and about $1 / 2$ inch wide, of a rich yellow color, perfectly stringless, excellent for home and market gardens. 1 1/2 pt. 15c., pt. 25c., qt. 50c., 1/2 pk. $\$ 1.75$, pk. $\$ 3.25$.

Wardwell's Kidney Wax. A favorite variety bearing long, flat pods of excellent quality. $\quad 1 / 2$ pt. $15 \mathrm{c}$., pt. $25 \mathrm{c}$., qt. 40 c., $1 / 2$ pk. $\$ 1.75$, pk. $\$ 3.25$.

\section{BROAD WINDSOR (English)}

The largest and best sort, very hardy. Plant as early in the spring as the ground can be worked, from 2 to 4 inches apart, in drills 3 feet apart. Cover the seed about 4 inches. Pt. 20 c., qt. 35 c., 2 qts. 60 c., $1 / 2$ pk. $\$ 1.10$., pk. $\$ 2.00$.

\section{BEANS, Pole}

Plant in hills 4 feet apart, 4 or 5 beans to a hill. Poles should be firmly set before planting.

Carmine Podded Horticultural. Pods bright carmine. Both pods and beans are much larger than the London Horticultural. An excellent variety for the market or the home garden. $1 / 2$ pt. 10c., pt. 20c., qt., 35c., 2 qts. 60 c., $1 / 2$ pk. $\$ 1.00$, pk. $\$ 1.85$.

Horticultural, or Speckled Cranberry. An old favorite, early and prolific; excellent quality either as a snap or shell bean or for cooking dry. $1 / 2$ pt. 10c., pt. 20c., qt. 30 c., 2 qts. 50 c., $1 / 2$ pk. 90 c., pk. $\$ 1.75$.

Kentucky Wonder, or Old Homestead. A long, green podded variety, very prolific and of fine quality. $1 / 2 \mathrm{pt}$. 10 c., pt. 15 c., qt. 30 c., 2 qts. 55 c., pk. $\$ 2.00$.

King of the Garden Lima. Large fine pods, vigorous and productive. The beans are of good size and of excellent quality: $1 / 2$ pt. $15 \mathrm{c}$., pt. 20 c., qt. 35 c., 2 qts. $65 \mathrm{c} ., \mathrm{t} / 2 \mathrm{pk} . \$ 1.10$, pk. $\$ 1.85$.

Large White Lima. A very popular variety. Beans are large and tender and of excellent flavor. $1 / 2 \mathrm{pt}$. 10c., pt. 20 c., qt. 35 c., 2 qts. 65 c., $1 / 2$ pk. $\$ 1.20$, pk. $\$ 2.25$.

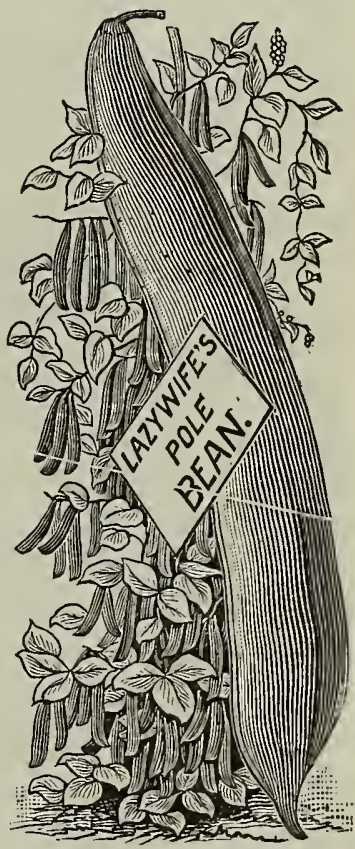

Small White Lima. Early and hardy. Beans small, good quality. T/2 pt. 15c., pt. 20 c., qt. 35 c., 2 qts. 65 c., $1 / 2$ pk. $\$ 1.20$., pk. $\$ 2.25$.

Lazy Wife's. Beans white; pods green, very thick, meaty, entirely stringless; very productive. $\quad 1 / 2$ pt. 10c., pt. 20 c., qt. 35 c., 2 qts. 65 c., $1 / 2$ pk. $\$ 1.20$, pk. $\$ 2.25$.

Red Cranberry. The pods are green, large and tender; one of the best snap beans. I/2 pt. 10c., pt. 20c., qt. 30c.

Scarlet Runner. An ornamental climber with bright scarlet flowers. $1 / 2$ pt. 15c., pt. 20 c., qt. 35 c., 2 qts. 60 c., $1 / 2$ pk. $\$ 1.00$.

White Runner. Similar to the Scarlet Runner, flowers being white. $1 / 2$ pt. $15 \mathrm{c}$., pt. 20 c., qt. 35 c., 2 qts. 60 c., $1 / 2$ pk. $\$ 1.00$. 


\section{BEET}

Sow as early in the spring as the ground can be worked. For successsion sow at intervals until the first of July. The soil should be well enriched with stable manure and plowed and harrowed until very fine. Sow in drills 15 inches apart and cover one inch. When well up thin out to 4 inches apart in the rows.

One ounce to fifty feet of drill; six pounds to the acre.

\section{EARLY WONDER.}

A fine early variety, the market gardener's favorite on account

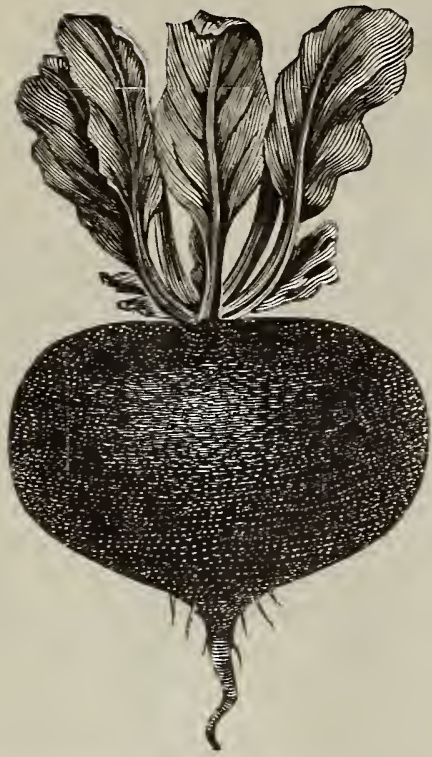

EDMAND'S BLOOD BEET of its symmetrical

form, dark color, small top and early maturity. We buy our seed of the originator. Pkt. 5c., oz, 10c., 2 oz, 20c., I $/ 4$ 1b. 30c., 1b. $\$ 1.00$.

Crosby's Egyptian. The roots are flattened, globe shaped and very smooth. Exterior color of root bright red. The flesh is bright vermillion red, zoned with a lighter shade, very sweet, tender and of excellent quality. Pkt. 5c., oz. 10c., 2 oz. 20c., 1/4 lb. 30c., 1b. $\$ 1.00$.

Detroit Dark Red. The best beet for the market and home garden. Tops small, upright in growth. Root medium-sized, globular or nearly round, very smooth, and of dark blood red color. Very desirable for bunching. Uniform in growth and unsurpassed in quality. Pkt. 5c., oz. 10c., 2 oz. 20c., 1/4 lb. 35c., lb. \$1.25.

Edmand's Blood Turnip. A medium early sort, deep red, popular with market gardeners. Our seed is grown from selected roots saved for seed. Pkt. 5c., oz. 10c., 2 oz. 15c., 1/4 lb. 25 c., lb. 75 c.

Crimson Globe. Second early globe shape and deep crimson flesh. Pkt. 5c., oz. 15c., 1/4 lb. 40c., lb. $\$ 1.25$.

Dewing's Blood Turnip. A standard variety. Pkt. 5c., oz. 10c., 2 oz. 15c., 1/4 lb. 20c., lb. 65 c.

Long Smooth Blood Red. A large late sort. Pkt. 5c., oz. 10c., I/4 lb. 20c., lb. 60 c.

\section{Swiss Chard or Spinach Beet}

The leaves are used as greens and served like spinach. The mid-ribs may be cooked like asparagus. Cuttings may be used all summer, as it can be cut down to the ground and new shoots will soon spring up and make fast growth.

Lucullus. The largest and best. Pkt. 5c., oz. 10c., 2 oz. 15c., $1 / 4$ lb. 20 ., lb. 60 c.

\section{Sugar Beets}

Sow 6 lbs. to acre. Sow in May or June in drills 2 inches deep, about 2 feet apart; thin out to 10 inches apart.

Giant Feeding

Sugar Beet, or

Half Sugar

Mangel.

strain of beets very desirable for stock feeding, affording not only a very large crop much easier to harvest than other sorts, but also having a higher nutritive value, being especially rich in sugar. Roots light bronze green above ground, grayish white below, with white flesh. On account of growing partly out of the ground and the long ovoid shape, the crop can be harvested and stored easily and at less expense than any other root crop. Oz. 5c., $\mathrm{t} / 4 \mathrm{lb}$. 15c., lb. 40c.

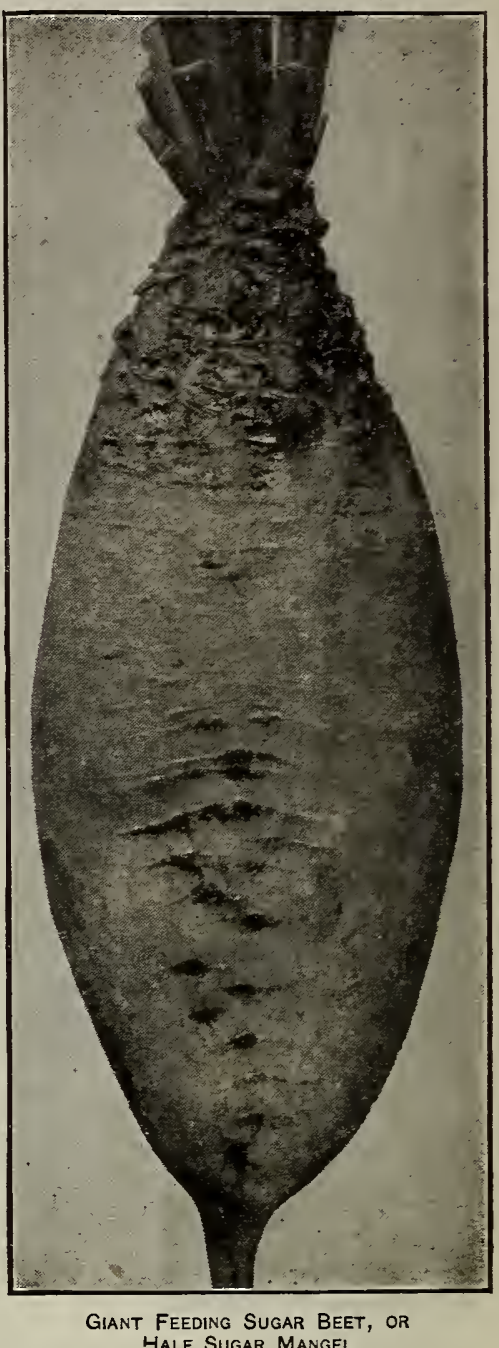

By parcel post, 5 lbs. $\$ 1.75$.

Lane's Imperial Sugar Beet. A hardy and productive variety; flesh snow white. Oz. 5c., 1/4 lb. 15c., lb. 35c. By parcel post, 5 lbs. $\$ 1.50$.

\section{Mangel Wurzel}

Mammoth Long Red. This variety produces roots of mammoth size and is enormously productive. Yielding from thirty to forty tons per acre on well prepared land. oz. 5c., I $/ 4$ lb. 15c., lb. 40c. By parcel post, 5 lbs. $\$ 1.75$.

Norbiton Giant. A standard variety. Oz. 5̌c., $1 / 4 \mathrm{lb}$. 15c., 1b. 40c.

Kelway's "Best of All." The largest and best of all yellow mangels. An improvement on all stocks of Yellow Mangels, one of the heaviest croppers and of very fine quality. Pkt. 5c., 1/4 lb. 20c., lb. 60c. By parcel post, 5 lbs. $\$ 2.50$.

Golden Tankard. Recommended for dairymen on account of its milk-producing properties. The flesh is a rich, golden yellow; very productive. $\mathrm{Oz} .5 \mathrm{c}$., $1 / 4 \mathrm{lb} .15 \mathrm{c}$., lb. 35c. By parcel post, 5 lbs. $\$ 1.50$. 


\section{CABBAGE}

The cabbage is an important crop and should be planted in fresh, rich soil, well manured and deeply dug or plowed. For early use sow in a hotbed in March, transplant to the open ground when danger from frost is past. Plant the early sorts about 18 inches in the rows and the late sorts about 2 feet in the rows and the rows about 3 feet apart. For the late crops sow in the open ground in June. Our cabbage seed is grown from selected stock and is equal to any offered in the market.

One ounce will produce about 2,000 plants.

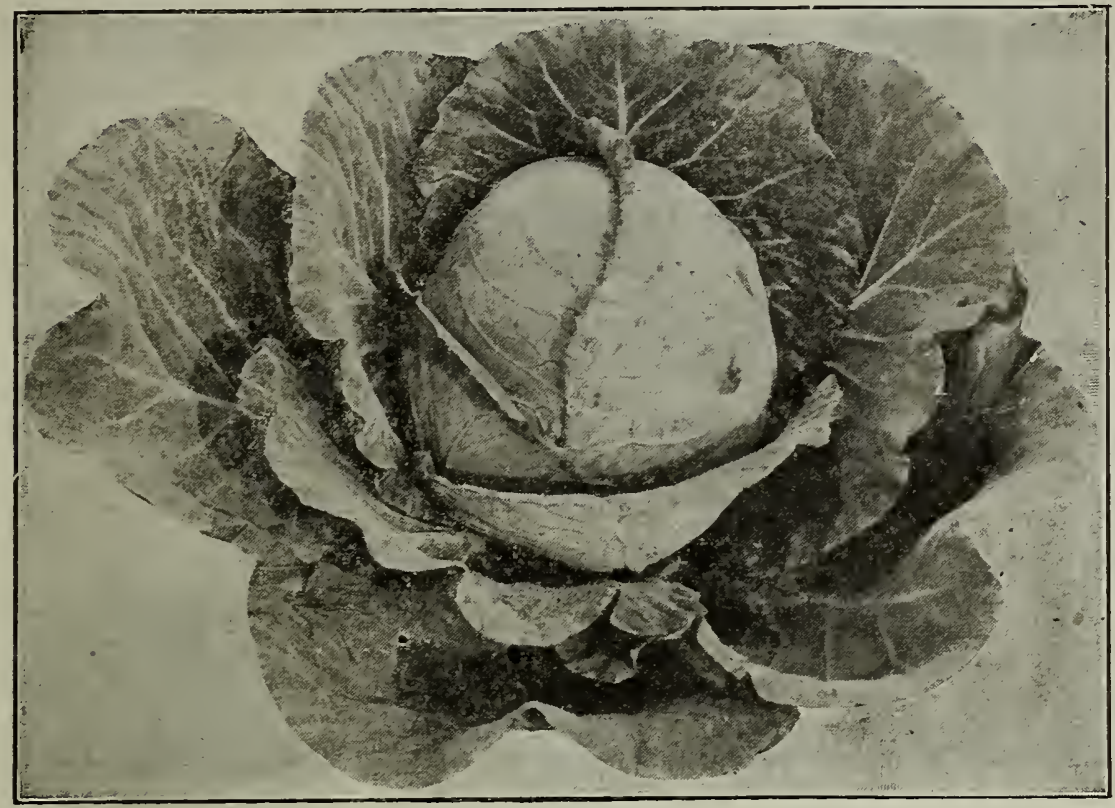

COPENHAGEN MARKET CABBAGE
COPENHAGEN MARKET.

An extra early variety: heads ball-shaped, large and solid, averaging in weight about 10 pounds. It will give perfect satisfaction both as to quality and yield, having few outside leaves. The plants can be set closer than most varieties. The most evenly-maturing and large-heading early cabbage in cultivation. Pkt. $5 \mathrm{c}$., $1 / 2$ oz. 20c., oz. 35c., 2 oz. 60c., $1 / 4$ lb. $\$ 1.00,1 b . \$ 3.50$.

Early Jersey Wakefield. A standard early market variety, conical in shape and good quality; heads uniform and solid. Pkt. 5c., I/2 oz. 15c., oz. 25c., 2 oz. $40 \mathrm{c}$., $1 / 4 \mathrm{lb} .75 \mathrm{c}$.

Henderson's Early Summer. A popular second early sort, heads round, medium size very solid and compact. Pkt. 5c., $1 / 2$ oz. 12c., oz. 20 c., 2 oz. 35 c., $1 / 4$ lb. $60 \mathrm{c}$.

Early Winningstadt. A hardy sort. heads conical shape, solid. Pkt. 5c., 1/2 oz. 10c., oz. 15c., $1 / 4$ lb. $45 \mathrm{c}$.

Fottler's Improved Brunswick. A fine summer or early fall variety, producing large, solid heads of fine quality with few outer leaves. Pkt. 5c., 1/2 oz. 12c., oz. 20 c., 2 oz. 35 c., I $/ 4$ lb. 60 c., lb. $\$ 2.00$.

All Seasons. Large heads, round and very solid and sure heading; nearly as early as the Early Summer. Pkt. 5c., 1/2 oz. 12c., oz. 20 c., 2 oz. 35 c., 1 $/ 4$ lb. 60 c., lb. $\$ 2.00$.

Succession. A good second early cabbage; similar to All Seasons. Pkt. 5c., I/2 oz. 12c., oz. 20c., 2 oz. 35 c., I $/ 4$ lb. 60 c., lb. $\$ 2.00$.

A. S. \& L., CAPE ELIZABETH.

Heads hard, solid, tender and crisp. It is remarkable for its long-keeping qualities. One of the best shipping varieties. Pkt. 10c., 1/2 oz. 25c., oz. 40 c., 2 oz., 70 c., 1/4 1b. $\$ 1.25,1$ b. $\$ 4.00$.

Warren's Stone Mason. An improvement on Stone Mason, round, medium-sized, solid heads, a good keeper. Pkt. 5c., 1/2 oz. 15c., oz. 25c., 2 oz. 40 c., 1/4 lb. 65 c., lb. $\$ 2.25$.

DANISH BALL HEAD.

This variety produces large, round and compact heads. One of the best keepers; plants vigorous and hardy, resisting cold and dry weather. Pkt. 5c., I $/ 2$ oz. 15c., oz. 25 c., 2 oz. 40c., I $/ 4$ 1b. 70 c., 1b. $\$ 2.25$

Marblehead Mammoth. The largest variety of Drumheads. Pkt. 5c., I/2 oz. 12c., oz. 20c., 2 oz. 35c., 1/4 lb. $60 \mathrm{c}$.

Improved American Savoy. Large, solid round heads, of superior quality, tender and good flavor, the best variety for family use. Pkt. 5 c., $1 / 2$ oz. 12 c., oz. 20 c., 2 oz. 35 c., $1 / 4$ lb. 60 c.

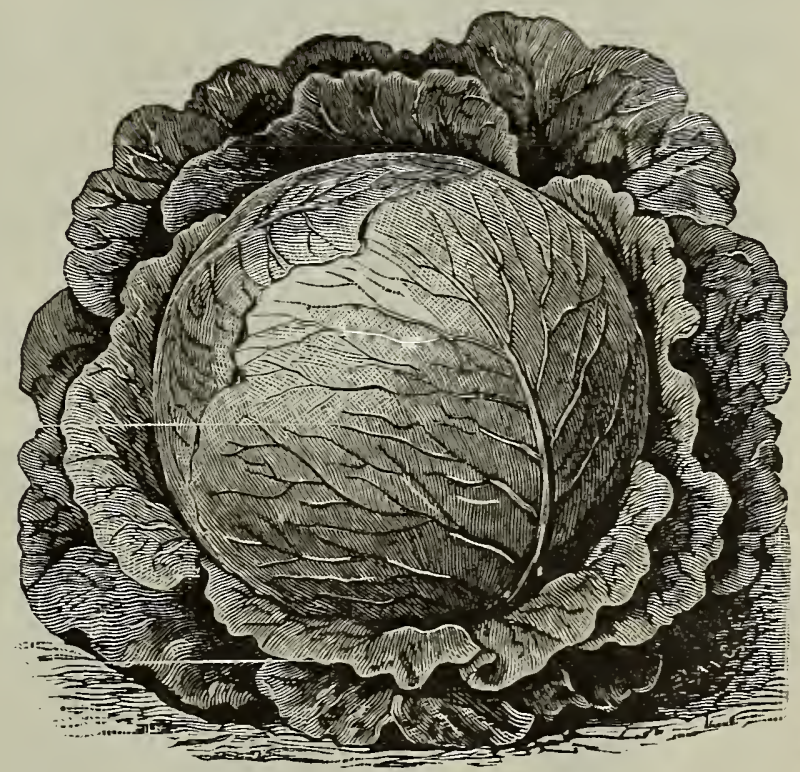

DANISH BALL HEAD CABBAGE

Red Danish Stone Head (New).

One of the largest and most solid and compact of the red varieties, sure heading and tender. $\mathrm{Pkt} 10 \mathrm{c}$., $1 / 2$ oz. 25 c., oz. 40 c., 2 oz. 75 c., I/4 lb. $\$ 1.25$.

Mammoth Red Rock. Heads dark red and solid, fine for pickling. Pkt. 5c., I/2 oz. 15c., oz. 25 c., 2 oz. 40 c., $1 / 4$ 1b. $70 \mathrm{c}$. 


\section{CAULIFLOWER}

The soil that will grow cabbage will grow cauliflower. It should be made richer and thoroughly worked before planting. For the early crop sow the seeds in a hotbed in February or March and transplant to cold frames 2 or 3 inches apart each way. They should be planted in the garden early in May. For the late cauliflower, plant in the open ground in June and transplant. in July.

One ounce will produce 2,000 plants.
Extra Early Dwarf Erfurt. Of dwarf growth with large, snow-white heads of regular shape; good for forcing. Pkt. 10c., $1 / 4$ oz. 40c., oz. $\$ 1.50$.

Earliest Dwarf Snowball. The earliest cauliflower in cultivation, absolutely sure to head when conditions are ordinarily favorable. Plants are very dwarf and of compact growth, with large, firm, snow-white heads. Pkt. 10c., I/4 oz. 40c., oz. $\$ 1.50$.

Thorburn's Gilt Edge. Produces large, solid, white heads of finest quality. Pkt. 10c., $1 / 4 \mathrm{oz} .75 \mathrm{c}$., oz. $\$ 2.00$.

Danish Giant or Dry Weather. This variety is about two weeks later than the Snowball. It is of dwarf growth, producing large, hard and snow-white heads, fully protected by its foliage. Pkt. $10 \mathrm{c}$., $1 / 4 \mathrm{oz} .75 \mathrm{c}$, oz. $\$ 2.25$.

Veitch's Autumn Giant. A large, late sort. Pkt. 5c., $1 / 2$ oz. 20c., oz. 35 c.

\section{CELERY}

For early celery sow the seed of the self-blanching sorts in a hotbed early in the spring. As soon as the plants are 3 inches high, transplant into frames in well-enriched soil 4 inches apart. Cut them once or twice before setting them out in May or June to make them stocky. When about six inches high transplant into trenches wide enough to hold two rows. The rows should be about 1 foot apart and the plants set about 8 inches apart. For winter celery start the seeds in flats as for early, only a little later. As the plants grow they should be earthed up to blanch, taking care not to cover the center of the plant.

One ounce of seed will produce about 4,000 plants

Paris Golden Self-Blanching. (French grown, special gardeners' strain). The finest early celery grown, easily blanched and of excellent flavor, solid and crisp. Pkt. 10c., 1/2 oz. 75 c., oz. $\$ 1.25,1 / 4$ lb. $\$ 4.25$.

Golden Self-Blanching. Seed grown in California. Pkt. 5c., 1/2 oz. 30c., oz. 50c., $1 / 4 \mathrm{lb} . \$ 1.50$.

White Plume. A desirable early variety, requiring very little labor in blanching. Pkt. 5c., 1/2 oz. 15c., oz. 25c., 1/4 lb. 60c.

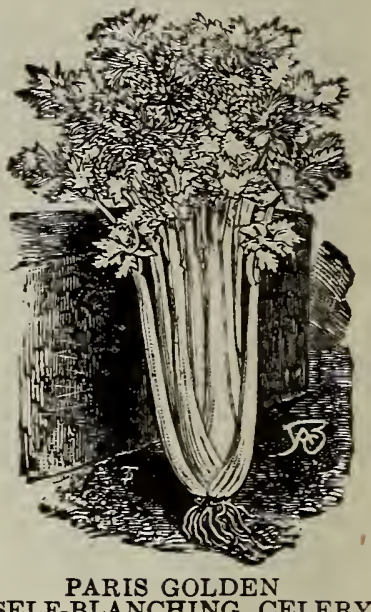

SELF-BLANCHING CELERY

Boston Market. White, solid, crisp and tender, the best late variety. Pkt. 10c., 1/2 oz. 30c., oz. 50c., 1/4 lb. \$1.50. Giant Pascal. A tall-growing sort, blanches early and keeps well. Pkt. 5c., $1 / 2$ oz. 10c., oz. 20c., 1/4 lb. 60c.

Soup Celery. For flavoring. Oz. 5c., 1/4 lb. 10c., lb. 30c.

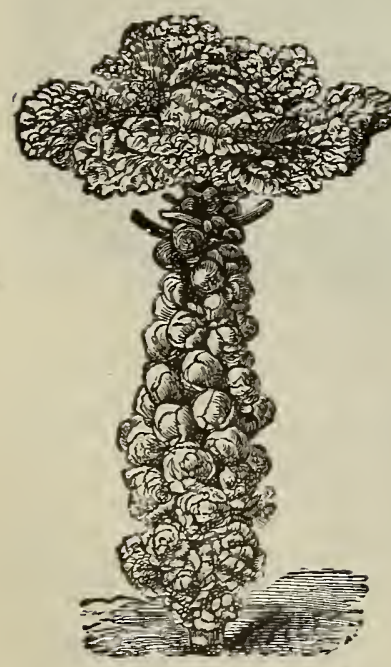

\section{Brussels Sprouts}

Cultivate the same as cabbage. The sprouts resemble miniature cabbage and are very tender.

Improved Dwarf. A standard sort. Pkt. 5c., oz. 15c. 2 oz. $25 \mathrm{c}$., $1 / 4 \mathrm{lb} .40 \mathrm{c}$.

Improved Long Island. The finest variety, very compact sprouts. Pkt. 5c. oz. 20 c., 2 oz. 35 c., $1 / 4 \mathrm{lb}$. $60 \mathrm{c}$.

\section{Broccoli}

A vegetable much resembling cauliflower.

White Cape. The most desirable variety. Pkt. 5c., oz. $35 \mathrm{c}$., $1 / 4 \mathrm{lb}$. $\$ 1.00$.

\section{Chives}

Hardy perennial plants grown for their tops, which are used as a salad and for flavoring soups. Seed, per pkt. 10c., oz. 50c. Roots 15c. per bunch, 25c. by mail prepaid.

\section{Chervil}

An aromatic sweet herb used for flavoring and garnishing.

Curled. Pkt. 5c., oz. 10c., 2 oz. 20c., 1/4 lb. 30c.

\section{Chicory}

The roots when dried and ground are used as a substitute for coffee; cultivation the same as the carrot.

Large Rooted. Pkt. 5c., oz. 10c., 1/4 lb. 25c.

\section{Cress or Peppergrass}

Sow early in the spring on rich soil in drills 10 or 12 inches apart and make frequent sowings every two weeks. Cover seed about $1 / 4$ inch.

Extra Curled. Fine flavor, may be cut several times. Pkt. 5c., oz. 10c., 2 oz. 15c., 1/4 lb. 20c., lb. 50c.

Water Cress. Sow in the spring near the margin of ponds or running streams. Pkt. $10 \mathrm{c}$., $1 / 2$ oz. $20 \mathrm{c}$, oz. $35 \mathrm{c}$., I/4 lb. $\$ 1.00$. 


\section{CORN, Sweet}

Plant in hills 3 to 4 feet apart each way, dropping 6 seeds in each hill, or in drills 3 to 4 feet apart. The seeds should be covered about 2 inches. In this climate Sweet Corn should not be planted before the middle of May. One quart will plant 200 hills.

Pkts. 10c. each prepaid. If other quantities are wanted by mail, add at the rate of $5 c$. per quart; half pecks and half-bushels at peck and bushel rates.

\section{Sweetser's Sunrise (New)}

An extra early variety with good sized ears. 10 to 12 rows, free f rom smut and filled out to the tip. The stalks are short with little foliage, 5 to 6 feet high; the sweetest and most tender of the early varieties. Our seed was grown by the originator in Cumberland County (Maine), always first in the Portland market. We are confident that this corn will be a money maker for the market gardener. Pkt. 10c., pt. 25c., qt. 40c., I $/ 2$ pk. $\$ 1,25, \mathrm{pk}$. $\$ 2.25$.

Burpee's Golden Bantam. Early, hardy and of the most delicious flavor; being of a dwarf growth, the stalks can be grown closely together in the row. Pkt. 10c., pt. 15c., qt. 25c.

Extra Early Mayflower. This variety is extremely early, being fit to use 60 days from planting. It is from 8 to 12 rowed, running mostly 10 rows. It is about the same size stalk as the Cory. Pkt. 10c., pt. 15 c., qt. 25 c., $1 / 2$ pk. 90 c., pk. $\$ 1.50$.

Ellis-Crosby Extra Early. An extra early and productive variety, ripening nearly as early as the Cory, growing very dwarf with ears set low, averaging from 16 to 20 rows; very sweet and tender. Desirable for both the market and private garden. The seed we offer was specially grown for us in New England for our retail trade. Pkt. 10c., pt. 15 c., qt. 25 c., 2 qts. 45 c., T/2 pk. 90c., pk. $\$ 1.75$.

Early Crosby (Selected). About ten days later than the Ellis-Crosby; largely used for canning. Pkt. 8c., pt. 12c., qt. 20c.

Peep-O'-Day. Extra Early and sweet, 2 to 3 ears to the stalk. Pkt. 10c., pt. 15 c., qt. 25 c., 2 qts. 40 c., $1 / 2$ pk. 75 c., pk. $\$ 1.50$.

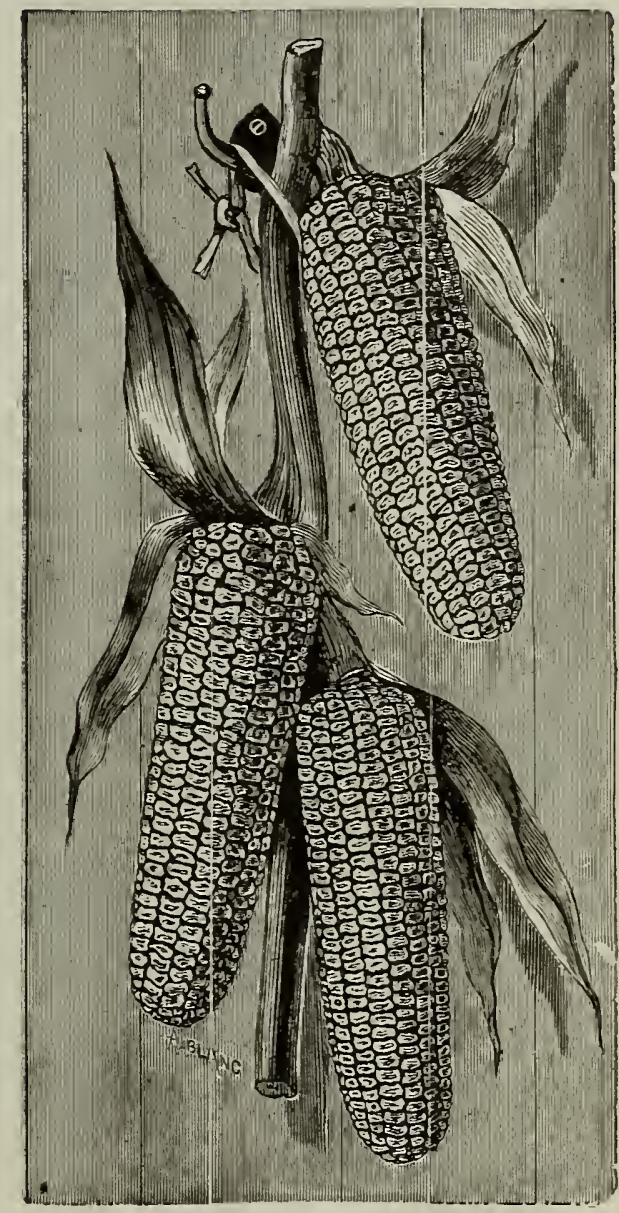

EILLIS-CROSBY SWEET CORN
Early Red Cory. A popular early variety. Pkt. 10c., pt. 15 c., qt. 20 c., 2 qts. 35 c., $1 / 2$ pk. 60 c., pk. $\$ 1.10$.

Early White Cory. Differs from the above in color of cob. Pkt. 10c., pt. 15c., qt. 20c., 2 qts. 35 c., $1 / 2$ pk. 60c., pk. \$1.10.

Bantam Evergreen. A cross between Stowell's Evergreen and Golden Bantam. Kernels are plump and full. The quality is very fine, being exceedingly sweet and tender. Ears 5 to 7 inches long. Pkt. 10c., pt. 20c., qt. 30c.

Black Mexican. Very sweet and tender, medium early. Pkt. 10c., pt. 15c., qt. 20c., 2 qts. 35 c., 1/2 pk. 65c., pk. $\$ 1.25$.

SEND US YOUR MAIL ORDERS.
Stowell's Evergreen. A late standard sort of excellent quality. Pkt. 10c., pt. 15c., qt. 25c., 2 qts. 40 c., $1 / 2$ pk. 70c., pk. $\$ 1.25$.

Country Gentleman. A large, late variety of excellent quality. Pkt. 10c., pt. 15c., qt. 20c., 2 qts. 35 c., $1 / 2$ pk. $65 \mathrm{c}$., pk. \$1.25.

Morse's Golden Gream. A cross between Country Gentleman and Golden Bantam, early, and prolific. The flavor is rich and delicious; seed, yellow. The habit of growth is rather dwarf, and the stalks bear 2 to 4 ears. Pkt. 12c., pt. 20c., qt. 30c., 2 qts. 50c., $1 / 2$ pk. 90 c., pk. $\$ 1.50$. 


\section{CUCUMBER}

For general crop plant when the ground has become warm, in hills 4 feet apart each way. Thin out to 4 plants to each hill after all danger of insects is over. For very early cucumbers sow about April 1st, in a hotbed on a piece of sod, grass side down so that they can be easily transplanted to the open ground when danger of frost is over. One ounce will plant fifty hills; two pounds will plant an acre.

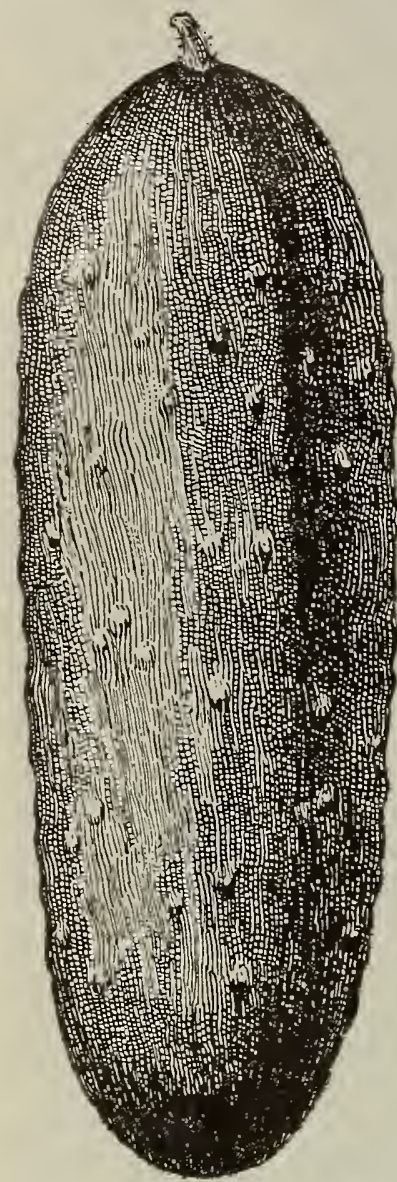

KLONDIKE CUCUMBER
Improved White Spine. One of the most popular varieties in cultivation. The fruit is light green with white spines, uniform in size and very productive. Pkt. 5c., oz. 10c., 2 oz. $15 \mathrm{c}$., $1 / 4$ lb. $25 \mathrm{c}$., 1b. $75 \mathrm{c}$.

Klondike. A medium early cucumber of very dark green color and an excellent quality for slicing; vine very hardy and productive. The fruits when mature are about 8 inches long. Its uniform size and shape and splendid color make this variety very popular as a shipping sort. Pkt. 5c., oz. 10c., 2 oz. 15c., $1 / 4$ lb. 25c., 1b. 75 c.

Boston Pickling. This variety is largely planted for pickles. Fruit medium size, smooth, light green and very productive. Pkt. 5c., oz. 10 c., 2 oz. 15 c., 1 $1 / 4$ lb. 25 c., lb. 75 c.

Cumberland. Fine variety for pickling or slicing. Vines are of strong growth and prolific and continue in bearing a long time. Pkt. 5c., oz. 10c., 2 oz. 15c., 1/4 lb. 25 c., lb. $75 \mathrm{c}$.

Davis Perfect. For forcing or outdoors. The fruit is of fine form, of a rich dark green color, very few seeds, tender, brittle and of fine flavor. Pkt. 5c., oz. 15 c., 2 oz. 20 c., $1 / 4 \mathrm{lb}$. 30c., lb. $\$ 1.00$.

Early Cluster. An early sort growing in clusters. Pkt. 5c., oz. 10c., 2 oz. 15c., $1 / 4$ lb. 25c., lb. 75 c.

Early Frame or Short Green. A well-known variety used for slicing and pickling. Pkt. 5c., oz. 10c., 2 oz. 15c., 1/4 lb. 25c., lb. 75c.

Early Russian. One of the earliest varieties, grows from 3 to 4 inches long. Pkt. 5c., oz. 10c., 2 oz. 15c., 1/4 lb. 25 c., lb. 85 c.

Long Green. An old standard variety. Fruit from 10 to 12 inches long, dark green and crisp. Pkt. 5c., oz. 10c., 2 oz. 15c., 1/4 lb. 25c., lb. $85 \mathrm{c}$.

Japanese Climbing. A quick-growing sort, throwing out tendrils which enable them to climb poles or trellises. Fruit from 12 to 16 inches long. Pkt. 5c., oz., 10c., 2 oz. 20c., 1/4 lb. 30c., 1b. $\$ 1.00$.

West India Gherkin. A small prickly variety grown only for pickles. Pkt. 5c., oz. 15c., 1/4 lb. $40 \mathrm{c}$.

\section{ENGLISH FRAME CUCUMBERS}

Kelway's "Freedom". An extraordinary cropper, and of first-rate quality; medium dark skin, 15 to 18 inches

Kelway's Extra Selected Telegraph. A popular varielong, per pkt. 25c.

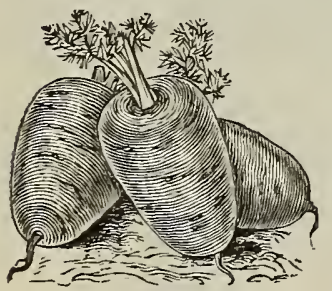

OXHEART CARROTS

\section{CARROT}

Carrots do best in a good, light and rich soil. Sow in April or May for the early crop, and for the main crop sow in May or June in drills about $1 / 2$ inch deep, in rows 14 inches apart, and thin plants to 3 or 4 inches in the rows. One ounce to 100 feet of drill; four pounds to an acre.

Early Scarlet Forcing. The earliest variety for forcing, small round roots and excellent flavor. Pkt. 5c., oz. 10c., I/4 Ib. 30c., lb. $\$ 1.00$.

Early Scarlet Horn. A favorite early variety, of fine flavor and excellent for the table. Roots grow about three inches long. Pkt. 5c., oz. 10c., 1/4 lb. 30c., lb. $\$ 1.00$.

Danvers' Half-Long. The best sort for the main crop, dark orange color, growing very smooth, yielding large crops, and is a splendid keeper; roots medium length, tapering uniformly to a blunt point. Pkt. 5c., oz. 10 c., 2 oz. 15 c., I/4 lb. 25 c., lb. 75 c.

Danvers' Half-Long. Special Market Gardeners' Strain. Pkt. 5c., oz. 15c., 1/4 lb. 50c., lb. $\$ 1.50$.

Wood's Selected Danvers' Half-Long. A superior strain of seed. Grow to a large size, small tap root and of the finest quality. Color a rich orange. Length, 8 to 10 in. Pkt. 5 c., oz, 20c., 1/4 lb. 60c., lb. $\$ 2.00$.
Chantenay. A medium early, half-long variety. The flesh is crisp and tender. Oz. 10c., $2 \mathrm{oz} .15 \mathrm{c}$., I/4 lb. $25 \mathrm{c}$., lb. $85 \mathrm{c}$.

Improved Long Orange. Deep orange color, roots of large size and a good keeper. Pkt. 5c., oz. 10c., 2 oz. 15 c., $1 / 4$ lb. 25 c., lb. 85 c.

Guerande or Oxheart. Medium early roots, short and thick. The flesh is bright orange, fine grained and tender. Pkt. 5c., oz. 10c., 2 oz. 15c., 1/4 lb. 25c., lb. $85 \mathrm{c}$.

Large White Belgian. Very productive and largely used for feeding stock. Pkt. 5c., oz. 10c., 2 oz. 15c., I $/ 4$ lb. 20c., lb. 60c. 


\section{DANDELION}

One of the earliest and most popular of spring greens. Sow in May in drills 12 inches apart; cover the seed $1 / 4$ of an inch deep. The following spring the plants will be ready for cutting.

One ounce for 200 feet of drill.

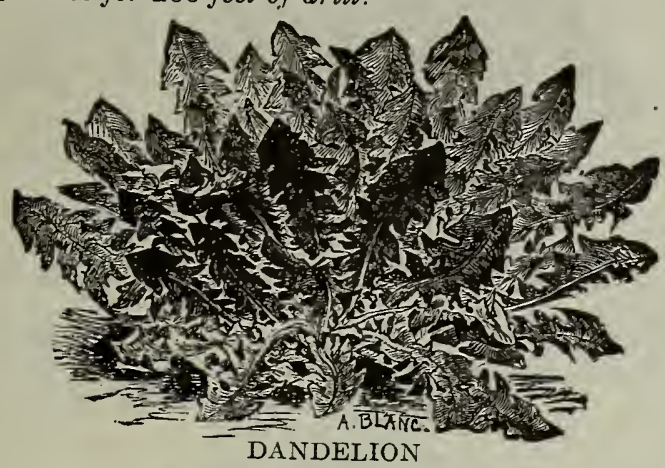

Improved Thick-Leaved. A carefully selected strain; popular with market gardeners. Pkt. 10c., $1 / 2$ oz. $25 \mathrm{c}$, oz. 40 c., 2 oz. 70 c., $1 / 4$ lb. $\$ 1.25$, lb. $\$ 4.50$.

\section{Egg Plant}

Sow the seeds in hotbeds very early in the spring and transplant when about three inches high into small pots or another hotbed. Do not plant out in the open ground until the weather has become warm and settled.

One ounce will produce about 1,000 plants.

New York Improved Purple. This variety produces fruit of large size, nearly round, dark purple and excellent quality. Pkt. 5c., r/2 oz. 20c., oz. 35c., 1/4 lb. $\$ 1.00$.

Black Beauty. A valuable early sort, about ten days earlier than the New York Improved; color a rich purplish black. Pkt. 5c., 1/2 oz. 20c., oz. 35c., 1/4 lb. $\$ 1.00$.

\section{Endive}

For early use sow as early in the spring as the ground can be worked in drills 15 inches apart. Transplant to 1 foot each way. When full grown tie the outer leaves at the top to blanch them.

One ounce will produce 2,000 plants.

Green Curled. A standard sort for fall and winter. Pkt. 5c., oz. 10c., 2 oz. 15c., 1/4 lb. 30c.

White Curled. A fine, white, curled variety, self-blanching. Pkt. 5c., oz. 10c., 2 oz. $15 \mathrm{c}$., I $/ 4 \mathrm{lb}$ l $30 \mathrm{c}$.

Broad-Leaved Batavian. A variety growing very compact, very tender and of fine flavor. Pkt. 5c., oz. 10c. 2 oz. $15 \mathrm{c} ., \mathrm{T} / 4 \mathrm{lb} .30 \mathrm{c}$.

French Endive (Witloof Chicory). Plant the seed in drills 10 inches apart, in deep, rich soil. Thin to six inches apart. One of the finest winter salads grown. Pkt. 5c., oz. 20c., r $/ 4$ lb. 40 c.

\section{Kale}

Sow from May to June, broadcast or in drills, cover $1 / 2$ inch, cultivate the same as cabbage.

One ounce to 150 feet of drill.

Dwarf Green Curled Scotch. A fine, low-growing variety, the leaves densely crimped and curled; very hardy and productive. Pkt. 5c., oz. 10c., $1 / 4 \mathrm{lb}, 25 \mathrm{c}$.$$
\text { Kohl Rabi }
$$

Seed should be sown in drills as early in the spring as possible. When well established, thin to 6 inches apart. The bulb grows entirely out of the ground.

Early White Vienna. A very early sort, excellent quality, flesh white and tender. Pkt. 5c., 1/2 oz. 10c., oz. $15 \mathrm{c}$., $1 / 4$ lb. $50 \mathrm{c}$.

Early Purple. Similar to the above except in color. Pkt. 5c., oz. 20 c., $1 / 4$ lb. 50 c.

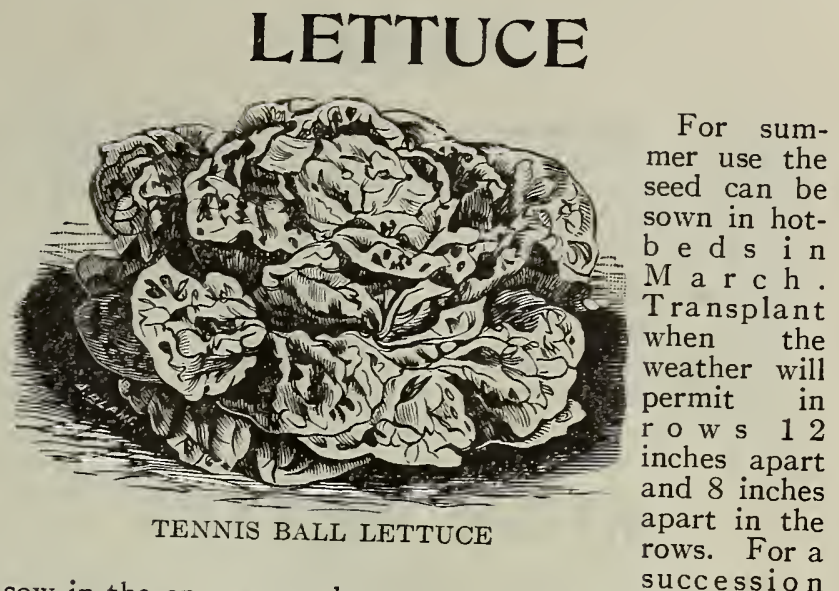

sow in the open ground every two weeks succession tuce requir a race requires a rich and a rather moist soil. The more apid the growth, the better the quality.

One ounce of seed will produce about 3,000 plants.

Big Boston. Fine for forcing or open-ground planting; large, solid heads. Pkt. 5c., 0z. 15c., 1/4 lb. 35c.

Boston Curled. Leaves beautifully curled, very attractive on table. Pkt 5c., oz. 10c., 1/4 lb. 30c.

Brown Dutch. An early sort with loose heads tinged with brown. Pkt. 5c., oz. 10c., $1 / 4$ lb. 30c.

Crisp as Ice. Large, solid heads, yellow heart, outside dark green and bronze. Pkt. 5c., $1 / 2$ oz. 10c., oz. $15 \mathrm{c}$.,

Early Curled Simpson. Very early, forms a close, compact mass of leaves. Pkt. 5c., oz. 10c., 1/4 lb. 30c.

Giant White Crystal. Solid head, excellent quality, crimpled. Pkt. 5c., oz. 15c., 2 oz. 20 c., $1 / 4$ lb. 30c.

Grand Rapids. A very popular variety, leaves crimpled, very attractive, matures quickly; the heads are dark green, very crisp and tender. Pkt. 5c., $1 / 2$ oz. 10c.,
oz. 15c., $1 / 4$ lb. 40 c.

Hanson. A large, solid variety. Pkt. 5c., oz. 10c., I/4 lb. $30 \mathrm{c}$

Hittinger's Belmont Forcing. Heads of larger size than the White-Seeded Tennis Ball, nearly as early and of crisp and tender quality; a superior forcing variety. Pkt. 10c., 1/2 oz. 25c., oz. 40c., 1/4 lb. $\$ 1.25$.

Market Gardener's Private Stock. A strain of BlackSeeded Tennis Ball, very desirable for hot bed culture in winter and for withstanding heat in summer. A light green, cabbage sort, forming hard heads. Pkt. 5c., $1 / 2$ oz. 10c., oz. 15 c., 2 oz. 25 c., $1 / 4$ lb. 40 c.

May King. Large, round, solid heads, one of the best varieties for planting in open ground. Pkt. $5 \mathrm{c}$., $1 / 2 \mathrm{oz}$. 10c., oz. $15 \mathrm{c} ., 1 / 4$ lb. $35 \mathrm{c}$.

Mignonette. Small, solid, compact, creamy yellow heads; leaves russet colored; very early and hardy, splendid quality. Pkt. 5c., oz. 10c., 2 oz. 15c., $1 / 4 \mathrm{lb}$. $35 \mathrm{c}$.

New York or Wonderful. The largest head lettuce, crisp and tender. Pkt. 5c., 1/2 oz. $10 \mathrm{c}$., oz. $15 \mathrm{c} ., 2 \mathrm{oz}$ 25c., $1 / 4$ lb. $40 \mathrm{c}$.

Tennis Ball, Black Seeded. A favorite variety for outdoor crop; forms close, hard heads that are crisp and tender. Pkt. 5c., oz. 15c., 2 oz. 20c., $1 / 4$ lb. 30 c.

Tennis Ball, White Seeded. A well-known forcing variety. Pkt. 5c., oz. 10c., 1/4 lb. 30c.

\section{Romaine or Cos Varieties}

Paris White Cos. An early sort with long, narrow leaves. Pkt. 5c., 1/2 oz. 10c., oz. 15c., 1/4 lb. 40c.

Trianon, Self-Folding Cos. Requires no tying to blanch, very crisp and tender. Pkt. 5c., I/2 oz. $15 \mathrm{c} ., \mathrm{oz}$. 


\section{LEEK}

Plant in the spring in a light, well-enriched soil in drills 1 foot apart. Cover the seed about 1 inch and thin to 9 inches apart in the drills. Draw earth up to them as they grow.

One ounce of seed to 150 feet of drill.

American Broad Flag. A strong-growing sort with broad leaves. Pkt. 5c., oz. 15c., 1/4 lb. 35c., lb. $\$ 1.25$.

Musselburgh. This variety grows to a large size, blanches well and is of superior flavor. Pkt. $5 \mathrm{c}$., oz. $15 \mathrm{c}$, , $1 / 4$ lb. $35 \mathrm{c}$., lb. $\$ 1.25$.

\section{MUSK MELON}

Melons succeed best in light, sandy, rich soil. After all danger of frost is past plant in hills 4 to 6 feet apart each way, six to ten seeds to a hill. When about 3 inches high and all danger from insects is past thin out to 3 or 4 plants to a hill.

One ounce to 60 hills; two to three pounds to an acre.

Burrell's Gem. Dark salmon flesh, delicious flavor. Pkt. 5c., oz. 10 c., $1 / 4$ lb. 30 c.

Emerald Gem. Fruit of medium size, very early and of fine flavor; flesh deep orange. Pkt. 5c., oz. 10c., $1 / 4 \mathrm{lb}$. $30 \mathrm{c}$.

Long Yellow. Very large, slightly ribbed and thickly netted; flesh salmon-yellow and sweet. Pkt. 5c., oz. 10c., 1/4 lb. 30c., lb. $\$ 1,00$.

Miller's Cream or Osage. Most delicious flavor, flesh salmon color, very thick and finely netted. Pkt $5 \mathrm{c}$., oz. 10c., $1 / 4$ lb. $30 \mathrm{c}$.

Montreal Market. A large-fruited variety, nearly round; skin dark green, heavily netted; flesh light green. Pkt. 5c., oz. 10c., $1 / 4$ lb. 30c.

Rockyford. A popular market variety. The fruit is oval, medium size, finely netted; flesh light green and very sweet. Pkt. 5c., oz. 10c., I $/ 4$ lb. 30 c.

\section{WATER MELON}

Plant in hills about 8 feet apart and cultivate the same as for Musk Melon.

One ounce for 30 hills; four pounds for one acre.

Cole's Early. One of the best early varieties, medium size, nearly round, flesh dark red and excellent quality. Pkt. 5c., oz. 10c., 1/4 lb. 25c.

Fordhook Early. Very early, good size, color medium green, flesh red and of good quality. Pkt 5c., oz. 10c. $1 / 4 \mathrm{lb} .25 \mathrm{c}$.

Mountain Sweet. An old variety, flesh red. Pkt. 5c., oz. 10c., $1 / 4 \mathrm{lb} .25 \mathrm{c}$.

Phinney's Early. Early and productive, flesh red. Pkt. 5c., oz. 10c., $1 / 4$ lb. 25 c.

Citron. Used for preserves; white flesh, hardy and productive. Pkt. 5c., oz. 10c., I/4 lb. $25 \mathrm{c}$.

\section{Martynia}

The seed pods which are produced in great abundance are gathered when young and tender for pickling. Sow in the open ground in May, 3 feet apart each way.

Proboscidea. The most productive variety. Pkt 5c., $1 / 2$ oz. 15 c., oz. 25 c., I $/ 4$ lb. 75 c.

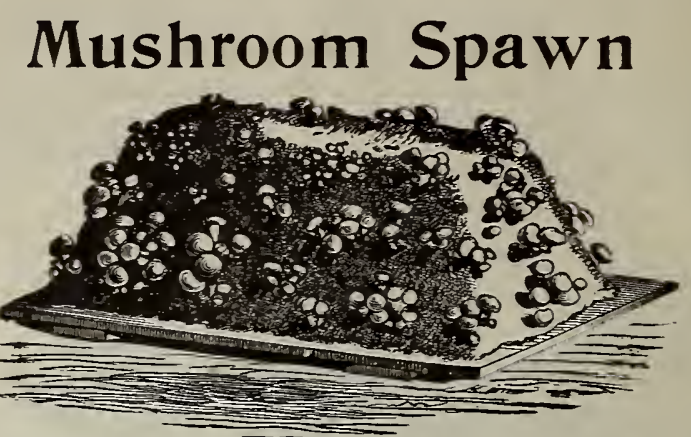

Mushrooms can be grown in cellars, in sheds, or in hotbeds where a temperature of 50 to 70 degrees is easily maintained.

English Spawn. In bricks 15c. per lb., 8 lbs. for $\$ 1.00$. If wanted by mail, add 10 cents per lb.

Books on Growing Mushrooms. Robinson's Book 50c., Falconer's Book $\$ 1.00$ postpaid.

\section{MUSTARD}

Sow thickly in early spring in shallow drills or in bo:es during the winter. Successive sowings may be made every ten days.

One ounce will sow about 75 feet of drill.

Black or Brown. Oz. 5c., 1/4 lb. 10c., lb. 30c.

Chinese. Leaves twice the size of the ordinary White

Mustard, which are curled and eaten boiled like spinach.

Pkt. 5c., oz. 10c., 1/4 lb. 20c.

White London. The best for salads and flavoring. $\mathrm{Oz}$. 5c., I/4 lb. 10c., lb. 25 c.

\section{Okra}

Sow the seeds late in the spring after the ground has become warm in rows about 3 feet apart, 1 inch deep, thinning out to about 9 inches apart in the rows.

Improved Dwarf Green. Very productive, long green pods. Pkt. 5c., oz. 10c., 1/4 lb. 20 c.

White Velvet. Large pods, smooth and free from ridges. Pkt. 5c., oz. 10 c., $1 / 4$ lb. 25 c.

\section{Pepper}

Sow the seeds in hotbeds early in April. Transplant when 2 or 3 inches high to 3 inches apart. Transplant to the open ground about the first of June, in rows 2 feet apart and 18 inches apart in the rows. The soil should be rich and mellow.

One ounce will produce about 2,000 plants.

Large Bell or Bull Nose. Large and of mild flavor, largely used for pickling. Pkt. 5c., I/2 oz. 15c., oz. 25c., 2 oz. 40 c., $1 / 4$ lb. 75 c.

Long Red Cayenne. Bright red, long, slender pods, very pungent. Pkt. 5c., 1/2 oz. 15c., oz. $25 \mathrm{c}$., 2 oz. 40 c., $1 / 4$ lb. $75 \mathrm{c}$.

Red Cherry. Small, round variety, bright scarlet fruit. Pkt. 5c., 1/2 oz. 15c., oz. 25c., 2 oz: 40 c., $1 / 4$ lb. 75 c.

Red Chili. Used for seasoning and for making pepper sauce. Pkt. 5c., I/2 oz. 15c., oz. $25 \mathrm{c}$., 2 oz. 40 c., $1 / 4 \mathrm{lb}$. $75 \mathrm{c}$.

Squash or Tomato-Shaped. Fruit medium size, early and productive. Pkt. 5c., $1 / 2$ oz. 15 c., oz. $25 \mathrm{c}$., $2 \mathrm{oz}$. $40 \mathrm{c}, 1 / 4 \mathrm{lb}, 75 \mathrm{c}$.

Sweet Mountain. The fruit is very large and smooth, flesh very tender and mild flavored. Pkt. $5 \mathrm{c} ., 1 / 2 \mathrm{oz}$. 15 c., oz. 25 c.; 2 oz. 40 c., $1 / 4$ lb. 75 c. 


\section{ONION}

Sow the seeds as early in the spring as the ground can be worked in drills about 1 foot apart and cover about $1 / 2$ inch. Thin plants to stand from 2 to 3 inches apart in the drills. The soil should be made very rich and kept free from weeds.

One ounce to 100 feet of drill; five pounds to the acre.

Danvers Yellow Globe. The most profitable variety to grow, producing bulbs of globular form which ripen early and uniformly, producing large crops. The seed we offer was grown in New England from selected bulbs by a reliable grower of long experience. We cannot recommend this strain of seed too highly, not only on account of its great yield but also of its superior keeping qualities. Pkt. 5c., oz. $25 \mathrm{c} ., 2$ oz. 40 c., $1 / 4$ lb. 65 c., 1b. $\$ 2.00$.

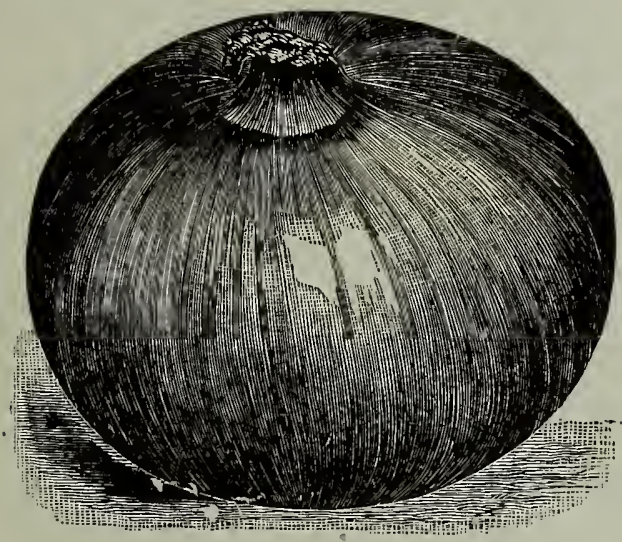

DANVERS' YELLOW GLOBE ONION

Extra Early Red Flat. About ten days earlier than the Red Wethersfield, medium size and a good keeper. Pkt. 5c., oz. 15c., 2 oz. 25 c., 1/4 lb. 45 c., lb. $\$ 1.75$.

Large Red Wethersfield. The standard red, flat variety, large size, skin deep purplish red, a good keeper. Pkt. 5c., oz. 15c., 2 oz. 25 c., 1/4 lb. 40 c., lb., $\$ 1.50$.

New Queen. A pure white variety of rapid growth; fine for pickling. Pkt. 5c., oz. 20c., $2 \mathrm{oz}$. $35 \mathrm{c}$., $1 / 4 \mathrm{lb}$. 60 c., lb. $\$ 2.00$.

Prizetaker. The largest yellow onion, flesh white and of mild flavor. Pkt. 5c., oz. 20c., 2 oz. 35 c., $1 / 4 \mathrm{lb}$. 50c., lb. $\$ 1.75$.

White Portugal. One of the best white sorts; bulbs mature early, very mild flavor, the best to grow for sets. Pkt. 5c., oz. 20c., 2 oz. 35 c., I $/ 4$ lb. 60 c., lb. $\$ 2.00$.

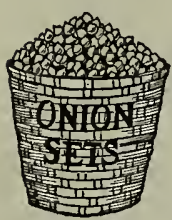

Onion Sets (Re-cleaned). Onion Sets should be planted as early in the spring as the ground is dry enough to work, in rows 12 inches apart and 2 to 4 inches apart in the rows.

Add $10 \mathrm{c}$. per quart if sent by mail.

White Sets. Qt. $25 \mathrm{c}$., $1 / 2 \mathrm{pk} .80 \mathrm{c}$., pk $\$ 1.50$.

Yellow Sets. Qt. 20c., I/2 pk. 65c., pk. $\$ 1.25$

Potato Onion Sets. Qt. 25 c., pk. $\$ 1.25$.

For larger quantities prices will be quoted on application.

\section{PARSNIP}

Sow as early in the spring as the weather will permit in deep, rich soil in drills 18 inches apart, covering the seed slightly; thin to 5 or 6 inches apart in the rows.

One ounce to 100 feet of drill; five pounds to the acre.

Abbott's Improved Hollow Grown. The roots are smooth, large, tender and sugary; a heavy cropper. Pkt. 5c., oz. 10c., 2 oz. 15c., 1/4 lb. 20c., lb. 50c.

Arlington Long Smooth. Roots long and smooth; a good market sort. Pkt. 5c., oz. $10 \mathrm{c} ., 2$ oz. $15 \mathrm{c}$., I/4 $\mathrm{lb}$. 20 c., lb. 50c.

Kelway's Don. A half-long variety, flesh very white, solid, recommended for market use. Pkt. 5c., oz. 10c., 2 oz. 20 c., $1 / 4$ lb. 30 c., lb. $\$ 1.00$.

\section{PUMPKIN}

Same cultivation as for squash. hills.

One ounce will plant 20 hills; one pound will plant_250

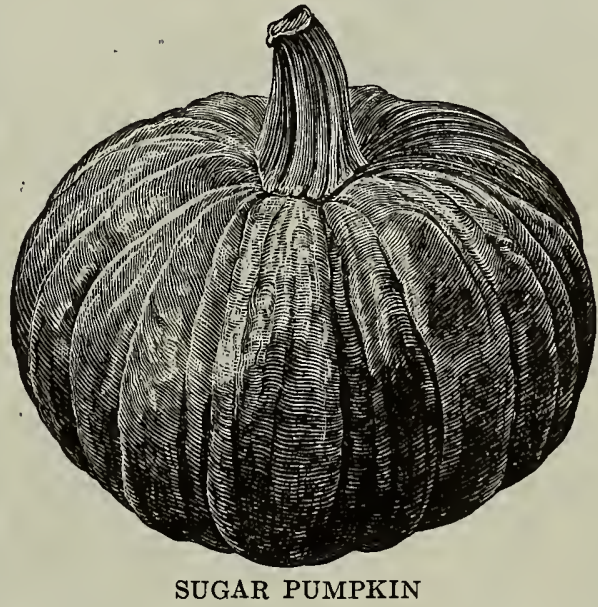

Connecticut Field. Very productive, usually grown in fields with corn for feeding stock. Oz. 5 c., $1 / 4$ lb. 10 c., lb. $40 \mathrm{c}$.

Large Cheese. A flat, yellow sort, very hardy and productive. Pkt. 5c., oz. 10c., 2 oz. 15c., $1 / 4$ lb. 20c., lb. 60c.

Mammoth Tours. Very large size, oblong in shape, largely used for feeding stock. Pkt. 5c., oz. 10c., $2 \mathrm{oz}$. 15c., 1/4 lb. 30c., lb. $\$ 1.00$.

Small Sugar. Very sweet and fine grained, a good keeper, best sort for family use. Pkt. 5c., oz. 10c., 2 oz. 15 c., $1 / 4$ lb. 20 c., lb. 60 c.

\section{PARSLEY}

Soak the seeds a few hours in lukewarm water and sow early in the spring in rich soil in drills one foot apart; thin out the plants to 4 inches apart in the rows.

One ounce to 150 feet of drill.

Double Curled or Covent Garden. One of the best sorts, handsome bright green color; leaves finely crimped and curley. Pkt. 5c., oz. 10c., 2 oz. 15c., r 14 lb. 25c., lb. 75 c.

Fern Leaved. A fine strain, very dark green. Pkt. 5c. oz. 10c., 2 oz. 15c., I/4 lb. $25 \mathrm{c}$, l lb. $75 \mathrm{c}$.

Hamburg or Turnip-Rooted. The roots resemble a small parsnip; used for flavoring soups, etc. Pkt. 5c., oz. $10 \mathrm{c}$., 2 oz., $15 \mathrm{c}$., 1/4 lb. $25 \mathrm{c}$., lb. $75 \mathrm{c}$.

"STERLING QUALITY" SEEDS MEAN THE BEST 


\section{PEAS}

Sow the early, smooth, round sorts as early in the spring as the ground can be worked in light, dry, rich, loamy soil. The wrinkled varieties are more tender and the seed is more liable to rot and should not be planted when the ground is cold and wet. The late varieties do not require as rich soil as the early and dwarf sizes. Sow in rows 3 to 4 feet apart and about 1 inch apart in the rows, 3 to 4 inches deep. Peas grown as a market crop are never staked, but when the taller sorts are grown for private use they are generally sown in double rows, 6 to 8 inches apart, and staked with brush. For best results all garden peas require good, strong fertile soil.

One quart will plant about 100 feet of drill; $1 \mathrm{I} / 2$ bushels to the acre.

Those marked with a (*) are wrinkled varieties.

If wanted by mail, add at the rate of $5 c$. per pt., 10c. per qt., half pks. and half bus. at pk. and bu. rates.

\section{Extra Early Varieties}

Alaska. One of the earliest blue peas, pods dark green, of medium size and uniform in growth; height $2 \mathrm{r} / 2$ feet. Pkt. 10c., pt. 15c., qt. $25 \mathrm{c} ., 1 / 2$ pk. 80 c., pk. $\$ 1.50$.

*Gradus or Prosperity. The earliest and most popular of the large-podded, wrinkled peas; vines vigorous, bearing large pods from 4 to $4 \mathrm{r} / 2$ inches in length, filled with large peas of the finest quality and delicious flavor; height 3 feet. $1 / 2$ pt. 10 c., pt. 15 c., qt. 25 c., $1 / 2$ pk. 95 c., pk. $\$ 1.75$, bu. $\$ 6.50$.

*Laxtonian. One of the most remarkable varieties yet introduced; very dwarf, growing only 12 to 15 inches high, producing pods in great abundance; nearly as large as the Telephone. The peas are large with a flavor the very sweetest and best. $1 / 2$ pt. $12 \mathrm{c}$., pt. $20 \mathrm{c}$., qt. 35 c., 2 qts. 65 c., $1 / 2$ pk. $\$ 1.25$, pk. $\$ 2.25$. bu. $\$ 8.00$.

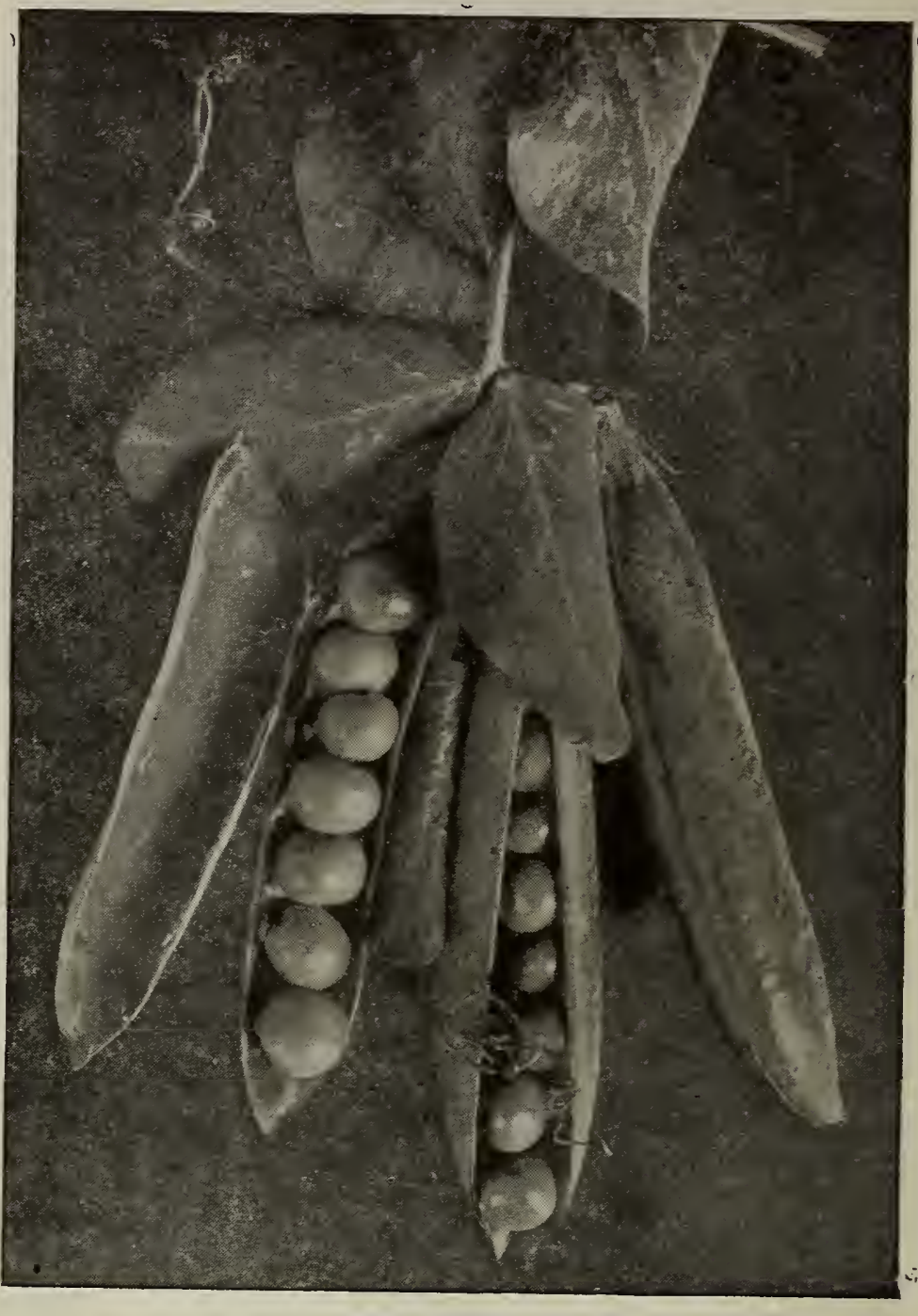

Little Marvel. A dwarf variety of even growth, about 18 inches in height; pods dark green, medium size, often produced in pairs; as early as Nott's Excelsior or American Wonder, equal in flavor and more prolific. $1 / 2 \mathrm{pt}$. 10 c., pt. 15 c., qt. 25 c., 2 qts. 45 c., r $/ 2$ pk. 90 c., pk. $\$ 1.75$, bu. $\$ 6.50$.

*Nott's Excelsior. A splendid early sort; pods are always well filled with large peas of delicious flavor. The vines are more vigorous than the American Wonder; height 15 inches. I $/ 2$ pt. 10 c., pt. 15 c., qt. 25 c., 2 qts. 45 c., I/2 pk. 90c., pk. $\$ 1.75$, bu. $\$ 6.00$.

Pedigree. A quick-growing, white, round pea; pods good size, well filled, nearly all maturing at one time; height $2 \mathrm{r} / 2$ feet. $1 / 2$ pt. $10 \mathrm{c}$., pt. $15 \mathrm{c}$., qt. $25 \mathrm{c}$., $1 / 2 \mathrm{pk}$. 90c., pk. $\$ 1.70$, bu. $\$ 5.00$.

*Sutton's Excelsior. As early as Nott's Excelsior, with much larger pods, a large cropper and of rich flavor; height $11 / 2$ feet. $1 / 2$ pt. $10 \mathrm{c}$., pt. $15 \mathrm{c}$., qt. $25 \mathrm{c}$., 2 qts. $45 \mathrm{c}$., $\mathrm{x} / 2$ pk. $90 \mathrm{c}$., pk. $\$ 1.75$, bu. $\$ 6.00$.

*Sutton's World's Record. Habit very prolific; pods long, dark green, filled with peas of superb flavor; height 3 feet. $1 / 2$ pt. $10 \mathrm{c}$., pt. $15 \mathrm{c}$., qt. $25 \mathrm{c} ., 2$ qts. $45 \mathrm{c}$., 1/2 pk. 95c., pk. $\$ 1.85$, bu. $\$ 6.75$.

*Thomas Laxton. Similar to Gradus. The pods are long, straight, with square ends, and contain 7 or 8 peas of the finest flavor; hardy and productive; height

3 feet. $\quad$ I $/ 2$ pt. 10 c., pt. 15 c., qt. 25 c., 2 qts. 45 c., $1 / 2$ pk. 90 c., pk. $\$ 1.75$, bu. $\$ 6.50$.

*Burpee's "Blue Bantam." An extra early variety of the finest quality. The vines average fifteen inches in height. The pods average nearly as large as the Gradus. Pkt. 10c., r/2 pt. 15c., pt. 25c., qt. 40 c.

\section{Second Early and Medium Varieties}

\section{*BUTTER CUP.}

A hardy variety of robust habit, vines bearing from 6 to 12 pods, each pod containing from 6 to 8 peas of excellent flavor. One of the best second early varieties for garden use. Height 2 feet. $1 / 2$ pt. 10c., pt. 20c., qt. 35 c., 2 qts. 65 c., $1 / 2$ pk. $\$ 1.25$, pk. $\$ 2.00$.

*Admiral Dewey. One of the finest and most desirable of the large-podded varieties. The vines are of vigorous growth; the pods are always of good size, well filled with peas of the highest quality; specially recommended for the home garden and market growing; height 4 feet. $\quad \mathrm{r} / 2$ pt. $10 \mathrm{c}$., pt. $15 \mathrm{c}$., qt. $25 \mathrm{c}$., 2 qts. $45 \mathrm{c}$., ז $/ 2$ pk. 90c., pk. $\$ 1.75$, bu. $\$ 6.00$.

PRICE IS SEGONDARY TO QUALITY. 


\section{PEAS-Continued}

\section{GENERAL GROP}

*Carter's Quite Content. The largest-podded variety yet introduced, vines and pods deep green, pods 7 to $7 \mathrm{I} / 2$ inches long, hanging mostly in pairs and contain 9 to 11 large peas of excellent flavor; recommended for the market or private garden; a large cropper; height 3 to 4 feet. $\quad 1 / 2$ pt. 15 c., pt. 25 c., qt. 50 c., 2 qts. 95 c., $1 / 2$ pk. $\$ 1.75$, pk. $\$ 3.25$, bu. $\$ 12.00$.

*Everbearing. Very prolific, pods about 3 inches long, peas large and of good quality; height $21 / 2$ feet. $1 / 2 \mathrm{pt}$. 10c., pt. 15 c., qt. 25 c., r $1 / 2$ pk. 75 c., pk. $\$ 1.35$, bu. $\$ 4.75$.

*Improved Telephone. An improvement on Carter's Telephone for purity and uniformity of habits, bearing in great abundance large, dark-green pods containing peas of fine flavor; height 4 feet. $1 / 2$ pt. 10c., pt. 15c., qt. 25 c., 2 qts. 45 c., I $/ 2$ pk. 90 c., pk. $\$ 1.75$, bu. $\$ 6.00$.

Dwarf Gray Sugar (Edible Pods). Height 2 feet. $1 / 2$ pt. 10c., pt. 20c., qt. 35c., pk. $\$ 2.00$.

Mammoth Podded Sugar (Edible Pods). Large, broad pods; cooked as string beans, they are sweet and tender; height 4 feet. $1 / 2$ pt. $10 \mathrm{c}$., pt. 20 c., qt. $35 \mathrm{c}$., pk. $\$ 2.00$.

Black-Eyed Marrowfat. Largely grown as a field crop; height 4 feet. Qt. $15 \mathrm{c}$., pk. $\$ 1.25$, bu. $\$ 4.50$.

White Marrowfat. Very hardy and prolific; height 4 feet. Qt. 15c., pk. $\$ 1.25$, bu. $\$ 4.50$.

White Canada Field. Valuable for sowing with oats for cattle feeding and for green soiling. $\mathrm{Pk} . \$ 1.00$, bu. $\$ 3.85$.

Any of the following Standard Varieties. Pkt. 10c., pt. 12c., qt. 20c., 1/2 pk. 70c., pk. $\$ 1.35$.

If wanted by mail, add at the rate of $5 \mathrm{c}$. per pt., $10 \mathrm{c}$. per qt.

\section{*American Wonder \\ *Duke of Albany \\ *Premium Gem}

*Champion of England

*McLean's Advancer

\section{Salsify or Vegetable Oyster}

One of the most delicious and nutritious of vegetables.

Sow early in the spring in drills 14 inches apart and 1 inch deep. Cultivate the same as for carrots and parsnips. They can be left in the ground until spring.

One ounce to 50 feet of drill.

Mammoth Sandwich Island. This variety grows to a large size and is superior in quality to the Long White. Pkt. 5c., oz. 15c., 2 oz. 25c., 1/4 lb. 40 c.

Read about these Specialties and Novelties. recommend them to our customers.

BEANS-Sure Crop Stringless Wax

Burpee's Kidney Wax-Burpee's Stringless Green Pod. French Horticultural Bush.

BEET-Detroit Dark Red. Early Wonder.

CABBAGE-Copenhagen Market.

Red Danish Stonehead

Danish Giant.

CELERY-Paris Golden Self-Blanching (French grown).

CAULIFLOWER-Danish Giant.

CARROT-Wood's Selected Danvers.
RADISH

The seeds should be sown in light, rich, sandy loam. For an early supply, sow in a hotbed in rows 4 inches apart. Sow in the open ground as soon as the ground can be worked in rows 8 to 12 inches apart, $1 / 2$ inch deep. If the radish makes rapid growth it will be crisp and tender. Sow every week or ten days for succession.

One ounce for 100 feet of drill.

Non Plus Ultra. The earliest forcing variety, round, red, maturing in about twenty days. Pkt. 5c., oz. 10c., 2 oz. 15c., 1/4 lb. 25c., lb. 65 c.

Crimson Giant. An extra early, turnip-shaped variety, growing very large, yet never pithy, always hard and solid; good for forcing and equally as good if grown in the open ground. Pkt. 5c., oz. 10c., 2 oz. 15c., $1 / 4$ lb. 25 c., lb. 70 c.

Early Scarlet WhiteTipped. Small, round, red, short tops, crisp and tender. Pkt. 5c., oz. 10c., 2 oz. 15 c., $1 / 4$ lb. 20 c., lb. $50 \mathrm{c}$.

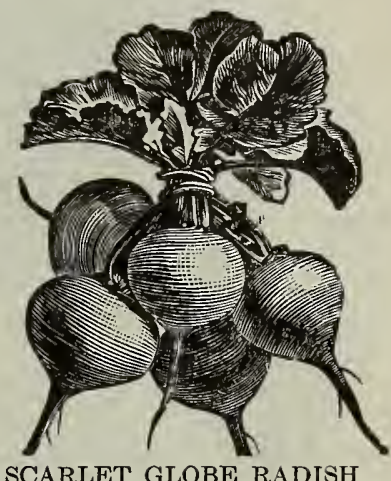

Scarlet Globe. One of the best varieties for forcing or sowing in the open ground; globe shaped, scarlet color, crisp and tender. Pkt. 5c., oz. 10c., 2 oz. 15c., $1 / 4 \mathrm{lb}$. 20c., lb. 50c.

French Breakfast. Oblong shaped, color scarlet, white-tipped, rapid grower, mild and tender. Pkt. 5c., oz. 10c., 2 oz. 15c., I/4 lb. 20 c., lb. $50 \mathrm{c}$.

Long Scarlet Short Top. Long and crisp, for frames or open ground. Pkt. 5c., oz. 10c., 2 oz. 15 c., I $/ 4$ lb. 20c., lb. 50c.

White Vienna. Finest white radish. It is long, slender, pure white, roots of excellent quality. Fine for forcing. Pkt. 5c., oz. 10c., 2 oz. 15 c., I $/ 4$ lb. 25 c., 1b. 60 c.

Early White Turnip. Flesh pure white and sweet, a fine forcer. Pkt. 5c., oz. 10c., 2 oz. 15c., $1 / 4$ lb. 20 c., lb. 50 c.

Long Black Spanish. A good winter variety. Pkt. 5 c., oz. $10 \mathrm{c}$ 2 oz. 15 c., $1 / 4$ lb. 20 c., lb. 50 c.

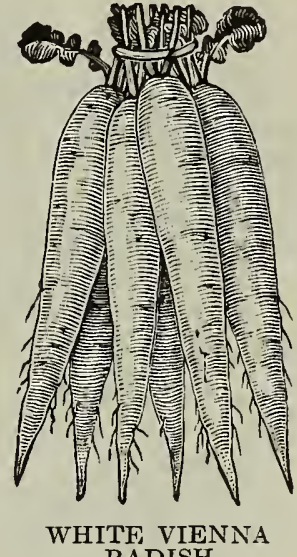

RADISH

They have all proven very satisfactory and we can

CORN-Ellis-Crosby (Sweet) Morse's Golden Cream (Sweet) Sweetser's Sunrise

CUCUMBER-Klondike. Wood's Hybrid. ONION-Danvers Yellow Globe (New England grown)

PEAS-Little Marvel Carter's Quite Content

Laxtonian

PARSNIP-Kelway's Don.

Buttercup

SWEDE TURNIP-Perfect Model.

TOMATO-Early Detroit

John Baer 


\section{SPINACH}

Sow early in the spring in drills one foot apart, covering the seed one inch deep, thinning out as it grows. For a succession sow every two weeks. For winter and early spring use, sow in August; cover with straw on the_approach of severe cold weather. acre.

One ounce to 50 feet of drill; ten to twelve pounds to the

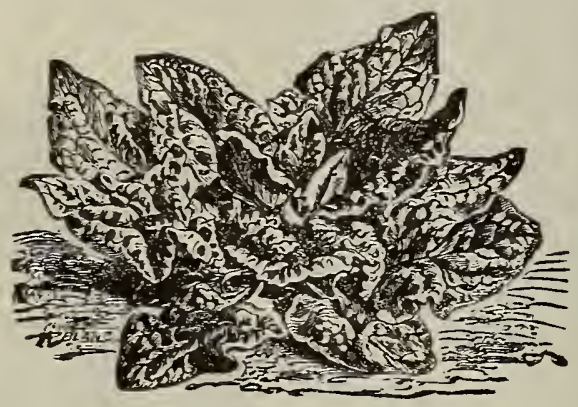

VICTORIA SPINACH

Giant Thick-Leaved. A large, dark-green, thick-leaved variety; stands a long time before running to seed. Pkt. 5c., oz. 10c. 1/4 lb. 30c., 1b. $\$ 1.00$.

Victoria. A variety of dense foliage, leaves thick and of a dark-green color. Pkt. 5c., oz. 10c., 1/4 lb. 30c., 1b. $\$ 1.00$.

Long Season. A dark-green, crumpled variety which withstands the hot weather without shooting to seed for a long time; very desirable for spring planting and of excellent quality. Pkt. 5c., oz. 10c., I/4 lb. 30c., lb. $\$ 1.00$.

Bloomsdale. A very hardy variety; large, thick, crumpled leaves, a favorite with Market Gardeners. The best for early spring or fall. Pkt. 5c., oz. 10c., I $/ 4$ lb. 30c., lb. $\$ 1.00$

Prickly or Winter. The hardiest variety for fall planting. Pkt. 5c., oz. 10c., 1/4 lb. 30c., lb. $\$ 1.00$.

New Zealand. A plant of branching habits which stands drought. Soak the seeds in warm water before planting. Plants should not be closer than 2 feet apart each way. Pkt. 5c., oz. 10c., 2 oz. 15 c., $1 / 4$ lb. 25 c., lb. 75 c.

"STERLING QUALITY" SEEDS MEAN THE BEST

PRICE IS SECONDARY TO QUALITY

SEND US YOUR MAIL ORDERS

ORDER EARLY TO AVOID DISAPPOINTMENT

\section{SQUASH}

Squashes are quite tender and should not be planted until the ground has become thoroughly warm and all danger of frost is past. Plant in light, rich soil, well pulverized. Bush varieties should be planted about 4 feet apart and the running varieties about 8 feet.

Bush varieties, one ounce to 40 hills; running varieties, one ounce to 15 hills, three to four pounds per acre.

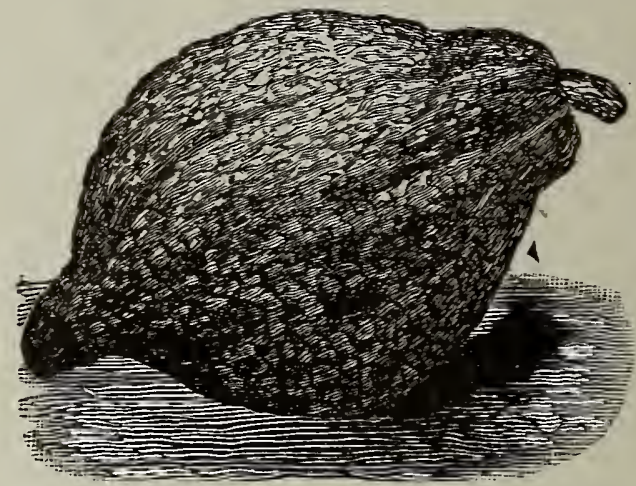

HUBBARD SQUASH

Early Summer Crookneck. A desirable table sort, bright yellow and attractive. Pkt. 5c., oz. 10c., I/4 lb. 20c., lb. 60c.

Giant Summer Crookneck. Large size, nearly double the size of the above. The flesh is thick, yellow and of fine quality. One of the best market varieties. Pkt. 5c., oz. 10c., I/4 lb. 20c., lb. 60c.

Yellow Bush Scallop. An early variety, very prolific. Pkt. 5c., oz. 10c., I/4 1b. 20c., 1b. 60c.

Mammoth White Bush Scallop. Pure white, producing large, thick fruit of fine flavor, early and productive. Pkt. 5c., oz. 10c., 1/4 lb. 20c., lb. 70c.

Delicious. Fine grained, sweet and dry, no other squash can equal it in sweetness and richness of flavor. In shape and color it is similar to the Hubbard. Weighs from five to ten pounds. Pkt. 5c., oz. 10c., 2 oz. 15c., I $/ 4$ lb. 25 c., 1b. 85 c.

Early Prolific Marrow. The earliest of the running varieties, maturing ten days earlier than the Boston Marrow; color a bright orange red; keeps well. Pkt. 5c., oz. 8 c., 2 oz. 15c., 1/4 lb. 20 c., lb. 65 c.

Boston Marrow. A standard fall variety of a bright yellow color, an excellent sort for pies and largely used by canners. Pkt. 5c., oz. 8c., 2 oz., 15c., 1/4 lb. 20c., lb. $65 \mathrm{c}$.

Turban. Orange yellow, fine grained and of good flavor. Pkt. 5c., oz. 10c., 2 oz. 15c., 1/4 lb. 25c., lb. 85c.

Warren. Has a shell harder than the Essex Hybrid and the color is of a deeper orange; the quality is superior. Pkt. 5c., oz. 10c., 2 oz. 15c., 1/4 lb. 25c., lb. 85c.

Hubbard. The standard winter squash, more largely grown than any other late variety, dark green skin and rich flesh, an excellent keeper. Pkt. 5c., oz. 10c., 2 oz. 15 c., $1 / 4$ lb. 25 c., 1b. 75 c.

Golden Hubbard. Same type as the Green Hubbard but of rich orange red color and earlier to mature. Pkt. 5 c., oz. 10 c., 2 oz. 15 c., I $/ 4$ lb. 25 c., lb. 75 c.

Mammoth Chili. Grows to an enormous size; color orange yellow. Pkt. 5c., oz. 10c., 2 oz. 15c., 1/4 lb. 30c., lb. 90c. 


\section{TOMATO}

Sow the seeds about the first week in March in a hotbed, greenhouse or in shallow boxes in a window. When the plants are about three inches high transplant to cold frames, setting the plants about 4 inches apart or in pots singly. Transplant to the open ground when all danger of frost is past. Set in rows 4 feet apart each way, using a shovelful of rotted manure in each hill. One ounce will produce about 1,500 plants.

Our Tomato Seeds are grown from selected Stocks.

John Baer. This new tomato is described by the originator as "the earliest tomato on earth." It produces perfect, solid, high crown, beautiful, brilliant red tomatoes, is almost seedless, and has a mild, deliciously sweet flavor. "'John Baer' Tomato is the offspring of two marvelous tomatoes, one great specialist having devoted ten years in selecting and improving one parent and another expert devoted five years in selecting and improving the other parent. The 'John Baer' Tomato is, therefore, the result of fifteen generations of improvement and selection for earliness, quality, shape, fruit, color and shipping quality. Will stand plenty of manuring without going to vine." Set plants $21 / 2 \times 3$ feet. Pkt. 5c., 1/4 oz. 20c., oz. 60c.

Early Detroit. Fruit very smooth, uniform in size, nearly globe shaped, firm and of excellent quality; color purplish pink; vine vigorous and productive. Pkt. 5c., $1 / 2$ oz. 20 c., oz. 35 c., 1/4 lb. $\$ 1.00$.

Earliana. The best extra early variety. It is the earliest large tomato; color bright red, growing in clusters of medium size, smooth, solid, and of fine flavor; excellent for the market and home garden. Pkt. $5 \mathrm{c}$., $1 / 2 \mathrm{oz}$. 15 c., oz. 25c., 2 oz. 40 c., $1 / 4$ lb. $75 \mathrm{c}$.

Chalk's Jewel. Color bright red; flesh thick and solid, good quality. Pkt. 5c., 1/2 oz. 15c., oz. 25c., 2 oz. 40 c., $1 / 4$ lb. $75 \mathrm{c}$.

Bonney Best. Early and prolific; fruit is smooth, round, scarlet, of fine flavor. Pkt. 5 c., $1 / 2$ oz. 15 c., oz. $25 \mathrm{c}$., 2 oz. $40 \mathrm{c}$., $1 / 4$ lb. $75 \mathrm{c}$.

Stone. The most reliable of the main crop, very large, bright scarlet, smooth, solid and very productive; is a good shipper. Pkt. 5c., 1/2 oz. 15c., oz. 25c., 2 oz. 40 c., $1 / 4 \mathrm{lb} .75 \mathrm{c}$.

Dwarf Champion. Plant dwarf and compact, medium size, good quality, color purplish pink. Pkt. 5 c., $1 / 2 \mathrm{oz}$. 15c., oz. $25 \mathrm{c}$., 2 oz. 40 c., $1 / 4$ lb. 75 c.

Dwarf Stone. Dwarf and compact growing, plant resembling Dwarf Champion but is of a stronger growth, yielding a large crop of very smooth, solid tomatoes of the finest quality, color bright scarlet. Pkt. 5c., $1 / 2 \mathrm{oz}$. 15c., oz. $25 \mathrm{c}$, 2 oz. $40 \mathrm{c}$., $1 / 4$ lb. $75 \mathrm{c}$.

Beauty (Livingston's). One of the best main crop tomatoes, vine large and vigorous, fruit purplish pink, smooth, large, solid and of excellent flavor. Grows in clusters of 4 to 6 and seldom cracks. Pkt. 5 c., $1 / 2 \mathrm{oz}$. 15c., oz. $25 \mathrm{c}$., 2 oz. 40 c., I $/ 4$ lb. 75 c.

Livingston's Perfection. Dark red, smooth, solid and productive. Pkt. 5c., 1/2 oz. 15c., oz. $25 \mathrm{c} ., 2$ oz. 40 c., $1 / 4 \mathrm{lb} .75 \mathrm{c}$.

Scarlet Globe. A desirable sort for both home and market use. Pkt. 5c., $1 / 2$ oz. 15c., oz. $25 \mathrm{c}$., 2 oz. $40 \mathrm{c}$, $1 / 4$ lb. $75 \mathrm{c}$.

Ponderosa. One of the largest varieties, flesh solid and of fine quality. Pkt. 5c., I/2 oz. 18c., oz. 30c., $2 \mathrm{oz}$. $50 \mathrm{c}$, $1 / 4$ lb. $90 \mathrm{c}$.

Acme. The fruit is a bright pink color, medium size, smooth and solid. Pkt. 5c., 1/2 oz. 15c., oz. 25c., 2 oz. 40c., $1 / 4$ lb. $70 \mathrm{c}$.

Red Cherry. Scarlet fruit about the size of a cherry, used for pickling. Pkt. 5c., 1/2 oz. 15c., oz. $25 \mathrm{c}$.

Yellow Cherry. Bright yellow, best for preserving. Pkt. 5c., 1/2 oz. 15c., oz. 25c.

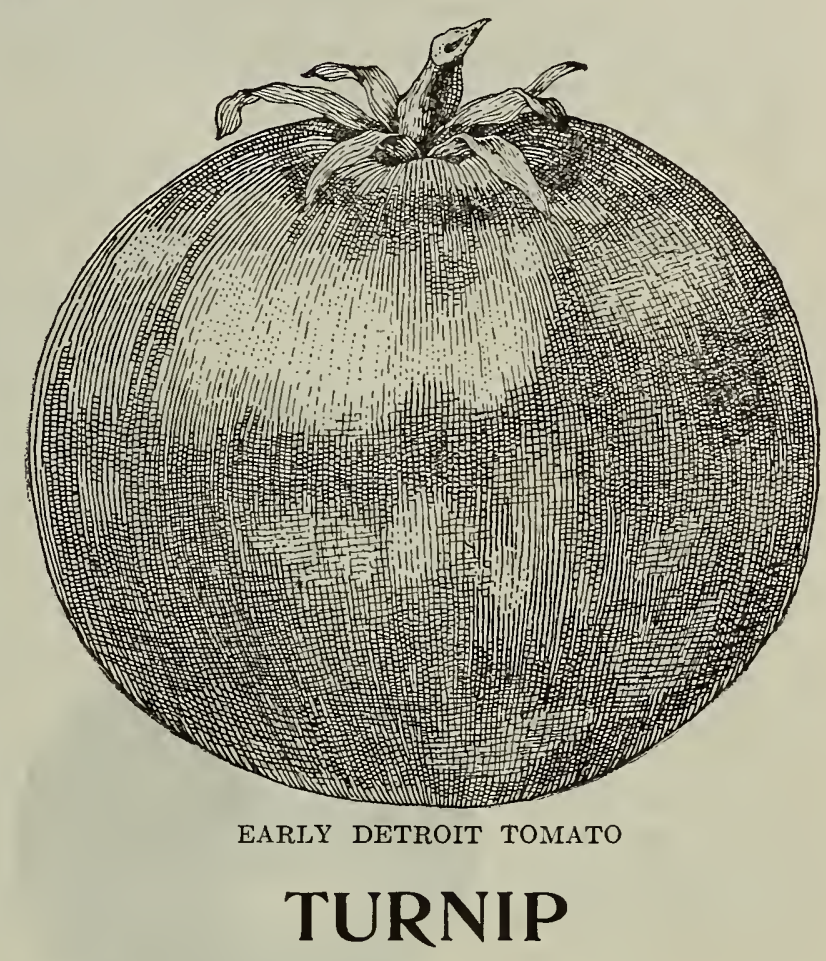

Turnips do best in rich, light, sandy soil. For early use, sow in the spring as soon as the ground can be worked in drills 1 foot apart. Cover $1 / 2$ inch deep. Thin plants to 6 inches apart. For a succession, sow every two weeks until August. Rutabagas are usually sown broadcast, but larger crops are obtained if the seed is sown in drills 18 inches apart and thinned out to 8 or 10 inches in the rows. Sow from June to the middle of July.

One ounce will sow 150 feet of drill; one to two pounds to an acre.

Early Purple Top Milan. One of the earliest flat turnips; flesh solid and of good quality. Pkt. 5c., oz. 10c., 2 oz. 15c., I/4 lb. 25c., lb. $75 \mathrm{c}$.

Early White Milan. Extra early; roots of medium size, pure white, sweet and tender. It is a rapid grower and desirable for early use. Pkt. 5c., oz. 10 c., 2 oz. 15 c., I $/ 4$ lb. 25 c., lb. $75 \mathrm{c}$.

Purple Top Strap Leaf. A $_{i}$ well-known and popular variety for the main crop, largely grown for both table and stock. 12c., $1 / 4$ lb. 15c., lb. $45 \mathrm{c}$.

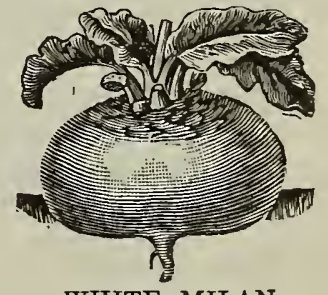

WHITE MILAN TURNIP

Pkt. 5c., oz. 8c., 2 oz.

Purple Top White Globe. An early variety, of superior quality, globe-shaped, white flesh, tender and sweet, one of the best for table use. Pkt. 5c., oz. 8c., 2 oz. 12c., $1 / 4$ lb. 15c., lb. 50 c.

White Egg. A pure white, egg-shaped variety of rapid growth; flesh firm, sweet and mild. Pkt. 5c., oz. 8c., 2 oz. 12 c., $1 / 4$ lb. 15 c., lb. 50 c.

Golden Stone. Flesh yellow, firm and fine grained, of fine quality, an excellent keeper. Pkt. 5c., oz. 8c., 2 oz. $12 \mathrm{c} ., 1 / 4$ lb. $15 \mathrm{c}$., lb. $50 \mathrm{c}$. 


\section{TURNIP_Continued}

Golden Ball. Very early, fine quality and of excellent flavor. Pkt. 5c., oz. 8c., 2 oz. 12c., I/4 lb. 15c., lb. 50c.

Cow Horn or Long White. A very productive, quickgrowing turnip, carrot-like in form, growing nearly half out of the ground. Pkt. 5c., oz. 8c., 2 oz. 12c., 1/4 lb. 15c., lb. 50c.

\section{Rutabaga or Swede Turnip}

\section{American Purple \\ Top. Very hardy, productive, and a good keeper; flesh yellow and solid, a fine variety $f$ or table use. Pkt. 5c., oz. 8c., 2 oz. 12c., 1/4 lb. 15c., lb. 50 c. \\ Carter's Imperial Purple Top. Very large and produc- tive; smooth, round heads, yellow flesh, and of good quality. Pkt. 5c., oz. 8c., 2 oz. 12c., I/4 lb. 15c., lb. $45 \mathrm{c}$.}

\section{Skirving's P u r ple} Top. A standard variety and a good keeper. Pkt. 5c., oz. 8 c., 2 oz. 12 c., $1 / 4$ lb. $15 \mathrm{c} .$, lb. $45 \mathrm{c}$.

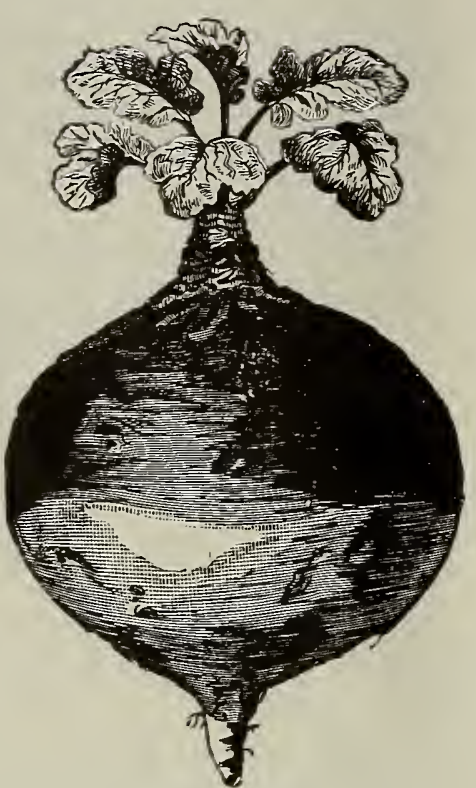

AMERICAN PURPLE TOP RUTABAGA

\section{Sweet and Medicinal Herbs}

Sow in the spring in shallow drills, 1 foot apart; when up a few inches thin out to proper distances, or transplant; cut the herbs when in flower, tie them up in small bunches and hang in the shade to dry.

Anise Annual.
Balm Perennial
Bassil, Sweet Annual
Caraway Biennial.
Catnip Perennial.
Coriander Annual.
Dill Biennial.
Fennel, Sweet Perennial.
Horehound Perennial.
Hyssop Perennial.
Lavender Perennial.
Marjoram, Sweet Annual.
Rue Perennial.
Saffron Annual.
Sage Annual. Per lb. $\$ 1.50$,
Summer Savory Annual.
Thyme Perennial.
Wormwood Perennial.
Mint Perennial

Per oz. 10c., pkt. jc. Per oz. 30c., pkt. 5 c. Per oz. 20c., pkt. 5c. Per oz. 10c., pkt. óc. Per oz. 40c., pkt. 5́c. Per oz. 10c., pkt. 5c. Per oz. 10c., pkt. óc. Per oz. 10c., pkt. 5c. Per oz. 25c., pkt. 5c. Per oz. 25c., pkt. 5 c. Per oz. 10c., pkt. 5 c. Per oz. 20c., pkt. 5c. Per oz. 20c., pkt. 5c. Per oz. 10c., pkt. 5c. Per oz. 15c., pkt. 5 c. Per oz. 15c., pkt. כ̌c. Per oz. 40c., pkt. 5 c. Per oz. 25c., pkt. כ̌c. pkt. $25 \mathrm{c}$.

\section{A., S. \& L. PERMANENT PASTURE MIXTURE}

This is a mixture composed of the best varieties of the different perennial Grasses and Clovers blended in the right proportions for giving a fine, heavy growth of pasture throughout the season, and which will last in the ground for many years.

The different varieties of Seeds for this mixture are selected with the view of combining in proper proportions varieties that will start early in the spring and those that will last late in the fall, and also those that will furnish good pasture during the hot, dry periods of summer. It is a mixture that has been highly recommended by expert Agriculturists.

One of the chief objections in the past to prepared mixtures has been that the quality of the different varieties of Seeds has been very inferior.

We can assure our customers that this mixture is made from only the very highest quality of Seeds which the market affords. Sow at the rate of $35 \mathrm{lbs}$. to the acre.

Price per acre, $\$ 8.00$, f. o. b. Portland. 


\section{FIELD CORN}

\section{Prices Subject to Market Changes}

Prices do not include delivery. Add cost of bags when ordering, as follows: $1 / 2$ bush., 10 cents; 2 bush., 20 cents. If ordered by mail add 10 cents per quart for postage.

Plant eight to ten quarts per acre in hills, one and one-half to two bushels broadcast, one bushel in drills.

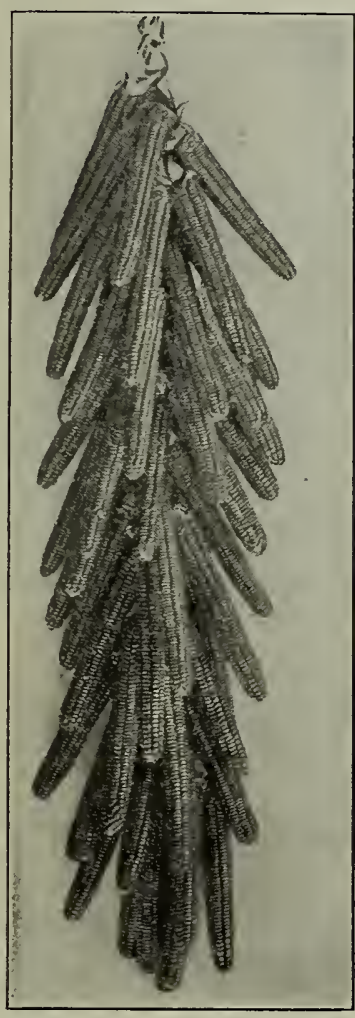

\section{ASHMONT GOLDEN FLINT}

A carefully selected strain of the Stickney Flint. By careful selection the time of maturity has been shortened from one to two weeks. A fine ensilage corn, growing, under even fair conditions, from 8 to 11 feet in height. Very heavy growth of luxuriant green leaves and stalks. Awarded first Premium at the annual exhibition of the Maine Seed Improvement Association held at Bangor, December, 1914, and at Lewiston, December, 1915. Qt. 25c., I/2 pk. 80c., pk. $\$ 1.50$, bu. $\$ 5.50$.

Genuine Eureka Ensilage. The corn that grows more ensilage to the acre than any other variety. It grows very tall, attaining a height of 12 to 15 feet and makes a heavy, thick growth of fodder. Qt. 15c., 1/2 pk. 40 c., pk. 75 c., bu. $\$ 2.25$.

\section{MOULTON'S NORTHERN KING FLINT}

This corn produces a large crop of fodder containing a good percentage of grain. Under favorable conditions it will grow from 12 to 20 tons per acre, growing from 10 to 12 feet high.

Qt. 20c., I/2 pk. 70c., pk. $\$ 1.25$, bu. $\$ 4.00$.

\section{MOULTON'S NORTHERN QUEEN FLINT}

An Early Flint Corn. Matures early and produces large crops. Qt. 20c., I/2 pk. 50c., pk. 90c., bu. $\$ 3.00$.

Mortgage Lifter. A heavy yielding, Yellow Dent Corn. Stocks are quite tall and furnish a large amount of fodder. Qt. 15c., pk. 65c., bu. $\$ 2.00$.

Watson's Early 8-Rowed Yellow Flint. The earliest yellow variety. Matures in about 90 days. Seed stock grown in Maine. Qt. 20c., pk. $\$ 1.00$, bu. $\$ 3.50$.

Longfellow. Eight-rowed, yellow kernel. Ears long, with small cob. Qt. 15c., pk. 65c., bu. $\$ 2.25$.

Leaming. Large deep grains, very early; stalks are leafy and make excellent fodder. Qt. 20c., pk. 50c., bu. $\$ 1.75$.
Red Cob Ensilage. White corn with red cob; matures late. $\mathrm{Pk} .50 \mathrm{c}$., bu. $\$ 1.75$.

Sanford. An early white flint, eight-rowed variety, largely grown for ensilage. Qt. 15c., pk. 60 c., bu. $\$ 2.00$.

Stickney Prize Yellow Flint. A fine corn for ensilage, grows from 10 to 12 feet high. Qt. 20c., pk. $\$ 1.00,{ }_{1} / 2$ bu. $\$ 1.75$, bu._ $\$ 3.00$.

Sweet Fodder. For ensilage, and a green summer food for stock. Qt. 15c., pk. 50c., bu. $\$ 2.00$.

White Rice Pop Corn. The most popular for general use. $1 / 2$ pt. $15 \mathrm{c}$, pt. 20c., qt. $35 \mathrm{c}$. 


\section{GRASS SEEDS, GRAINS, ETC. PRICES OF GRASS SEEDS SUBJECT TO CHANGE SPECIAL QUOTATIONS WITH SAMPLES ON APPLICATION}

Prices do not include delivery. Add cost of bags when ordering, as follows: $1 / 2$ bush., 10 cents; 2 bush., 20 cents. If ordered by mail add 10 cents per quart for postage.

Creeping Bent. A variety of rapid growth and spreading habit, fine for lawns and putting greens.

Italian Rye Grass. A variety that thrives in almost any soil and yields abundant crops.

Kentucky Blue Grass. An excellent grass for pastures and lawns.

Meadow Foxtail. Valuable for permanent pastures.

Meadow Fescue. An excellent pasture grass.

Orchard Grass. Yields large crops of excellent hay, also valuable for pastures, and also succeeds in shady situations better than most other grasses.

Perennial Rye Grass. Grows rapidly, making a good growth within a month from time of sowing.

Rhode Island Bent Grass. A valuable perennial for lawns.

Sheep's Fescue. A small tufted, hardy grass, thrives on light, dry soils and in shady locations where other grasses would fail.

Sweet Vernal (Annual). Lasts only one season. Imparts a fragrant odor to grass while being cut.

Sweet Vernal (Perennial) Same as the annual variety. with the exception that it is of a perennial nature.

Tall Meadow Oat Grass. It is recommended for hay and for a soiling crop.

Washington Oats. A fine, heavy oat, originating in New York. One of the best and most reliable of spring oats. It is an open-headed or tree type of oats, thin hulls making them especially valuable as a feeding oat. They are less liable to rust than most any other sort. Weight, 36 to 40 lbs. measured bushel. Crop failed.

American Banner Oats. This variety makes a strong growth of straw. The heads are large and bushy, yielding large crops of oats of fine quality. Per pk. $35 \mathrm{c}$., bu. $\$ 1.25$, bags included.

Barley, Chevalier. A two-rowed variety, very hardy and productive. The grain is large and plump.

Barley, Beardless. Pk. 60c., bu. $\$ 2.00$.

Spring Wheat (Fife). A red, beardless variety, hardy and productive.

Spring ${ }^{\nabla}$ Rye. An excellent crop for fodder or grain. Write for prices.

Winter Rye. The ordinary variety for fall sowing. Write for prices.

Buckwheat (Japanese). The best and most profitable variety. It is earlier and more productive than the Silver Hull. Pk. 50c., bu. $\$ 1.75$.

Buckwheat (Silver Hull). A very good variety. Grain is light gray in color. $\mathrm{Pk}$. 50c., bu. $\$ 1.75$.

"STERLING QUALITY"
Tall Fescue. A valuable perennial grass. Succeeds best on moist soil.

Timothy. One of the most important of hay grasses, producing a larger crop than any other grass when sown on rich loamy or clayey soils. We sell only the purest and best seed obtainable.

Wood Meadow Grass. Of early growth and thriving well under trees where other grasses will not grow.

Alsike Clover. A hardy variety and one of the best for sowing with other clovers or grasses. The blossoms are fragrant and are much liked by bees.

Alfalfa or Lucerne Clover. Valuable as a hay and forage crop.

Crimson Clover. An annual variety growing about one foot high.

White Clover. Largely used in lawn and pasture mixtures.

Red Clover. Excellent for pastures and hay. Adds humus to the soil wherever it is sown.

Hungarian. A popular annual used for hay and forage, yielding two or three tons of hay per acre.

Golden Millet. Grown for hay or green fodder.

Japanese or Barnyard Millet. A popular forage plant of excellent quality, growing 6 to 8 feet in height and yielding 10 to 20 tons per acre.

Sweet Clover, Bokhara (Melilotus Alba). Used as a soil-improving crop.

Dwarf Essex Rape. A forage plant of great value, furnishing rich pasturage for sheep, hogs or cattle within six weeks from the time of sowing. It also makes splendid green feed for poultry. It is sown broadcast at the rate of 4 to 6 lbs. to the acre, but will yield much better when sown in drills, pat the rate of 2 to 3 lbs. per acre. Per lb. 12c., by mail 15c.; per 100 lbs. $\$ 9.00$.

Soja Beans. Valuable as a forage crop or green manure; also as a green fodder and silo plant. Early Hollybrook, qt. 20 c., pk. $\$ 1.00$, bu. $\$ 3.50$. Early Green, qt. 20c., pk. $\$ 1.25$, bu. $\$ 4.50$.

Velvet Beans. Used in the South as a forage plant, also an excellent fertilizing plant for plowing under. Qt. 25c., pk. $\$ 1.50$, bu. $\$ 5.00$.

Southern Cow Peas. One of the largest yielding forage crops grown. New Era. An early maturing variety. Qt. 20c., pk. $\$ 1.00$, bu. $\$ 3.50$.

Spring Vetches or Tares. Valuable for soiling, also grown with oats for feeding to stock. Lb. 8c.; per 100 lbs. $\$ 6.50$.

Winter Vetches or Tares. Very hardy, recommended for fall sowing with rye. Lb. $25 \mathrm{c}$.

Kaffir Corn. Makes a large growth of forage. The grain makes an excellent feed for poultry. Lb. Sc.; per 100 lbs. $\$ 5.00$. 


\section{LAWN GRASS SEED}

Lawns made from seed are generally superior to those made by laying turf, and there is a large saving in the expense. The soil should be carefully prepared, made firm and smooth, well drained, and enriched with commercial fertilizer or well-rotted manure.

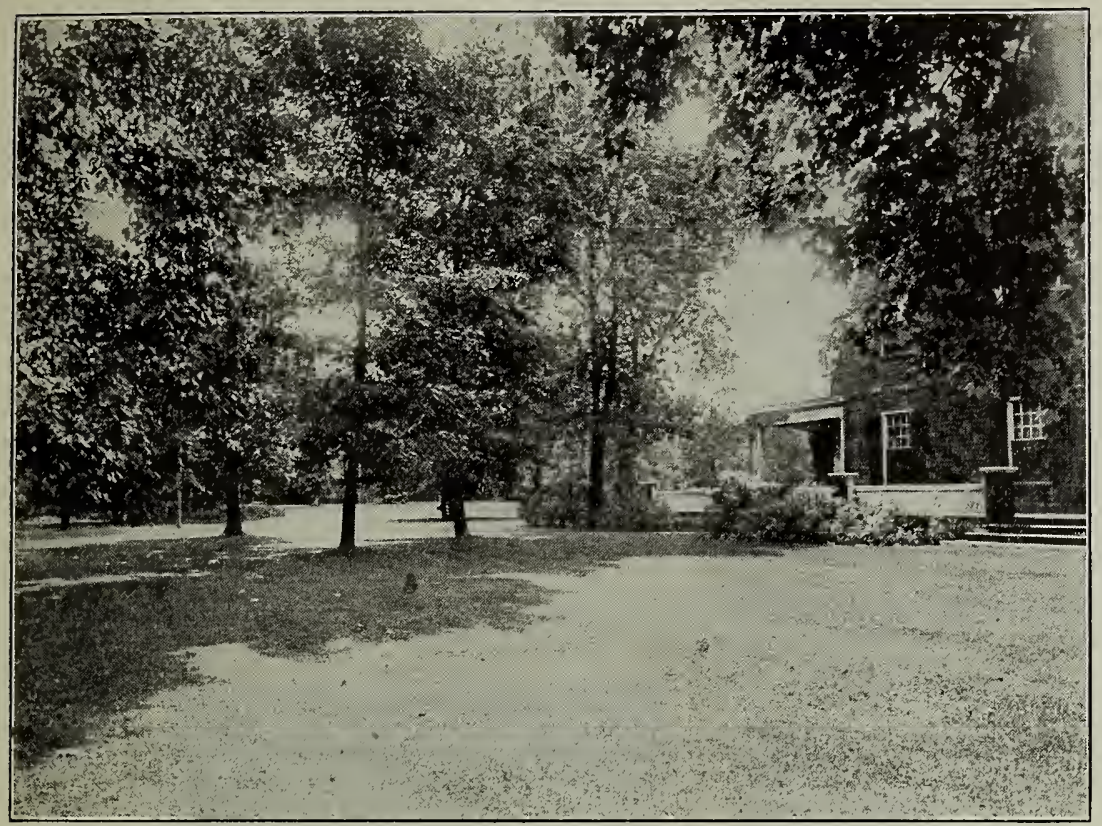

A., S. \& L. EXTRA FINE MIXED. A combination of the finest and purest grasses best adapted for a permanent lawn. For beautiful, velvety lawns, the "A., S. \& L." Lawn Grass is the best that can be used. We have received many complimentary reports from customers who have used this Lawn Seed. Lb. 25c., by mail 30c.

Pinetree. This mixture is composed of grasses adapted to general lawn purposes. Lb. 20c., by mail 25c.

\section{A., S. \& L. Golf Links Mixture.} Made from a formula that will produce a turf which will withstand rough usage. Lb. 35 c., by mail 40 c.

A., S. \& L. Putting Green Mixture. The varieties in this mixture are the finest, low growing and most hardy kinds. Lb. 35c., by mail 40c.

TABLE SHOWING THE QUANTITY OF SEED USUALLY SOWN UPON AN ACRE

Lbs. per bush.

Barley, broadcast

Beans, Dwarf, in drills

Beans, Pole, in hills

Beets, Table, in drills

Beets, Mangel-Wurzel

Buckwheat

Cabbage, in beds to transplant

Carrot, in drills

Clover, Red

Clover, White

Clover, Alsike

Clover, Lucerne or Alfalfa

Corn, in hills

Corn, for fodder

Cucumber, in hills

Grass, Kentucky Blue

Grass, Orchard

Grass, Red Top (Recleaned)

Grass, Timothy

Grass, Hungarian

Grass, Lawn

Melon, Musk, in hills

Lbs, per bush.

482 to 3 bush.

$6011 / 4$ bush.

6010 to 12 qts. 6 lbs.

6 lbs.

481 bush.

I $/ 4 \mathrm{lb}$.

3 to 4 lbs.

6015 to $20 \mathrm{lbs}$.

6012 to $15 \mathrm{lbs}$.

6010 lbs.

6030 lbs.

10 qts.

3 bush.

2 lbs.

143 bush.

143 bush.

406 lbs.

$45 \mathrm{r} / 2$ bush.

481 bush.

253 bush.

2 to 3 lbs.
Melon, Water, in hills

Millet, Japanese

Millet, German

Oats, broadcast

Onion, in drills

Onion Sets, in drills

Parsnip, in drills

Peas, broadcast

Peas, in drills

Potatoes (Cut Tubers)

Pumpkins, in hills

Radish, in drills

Rye, broadcast

Sage, in drills

Spinach, in drills

Squash, (Bush Varieties), in hills

Squash, (Running Varieties), in hills

Tomato, to transplant

Turnip, broadcast

Turnip, in drills

Vetches, broadcast

Wheat, broadcast
4 to 5 lbs.

4025 lbs.

501 bush.

322 to 3 bush.

5 lbs.

8 bush.

5 lbs.

3 bush.

$11 / 2$ bush.

608 bush.

4 lbs.

8 lbs.

$561 \frac{1}{2}$ bush.

8 lbs.

10 lbs.

2 lbs.

3 lbs.

$\mathrm{I} / 4 \mathrm{lb}$.

2 lbs.

$11 / 2 \mathrm{lbs}$

2 to 3 bush.

$601 \frac{1}{2}$ to 2 bush.

\section{QUANTITY OF SEEDS REQUIRED FOR A GIVEN NUMBER OF HILLS OR LENGTH OF DRILL}

\author{
Asparagus \\ Beet \\ Beans, Dwarf \\ Beans, Pole \\ Carrot \\ Cucumber \\ Corn \\ Dandelion \\ Melon, Water \\ Melon, Musk \\ Onion
}

\begin{tabular}{|c|c|c|}
\hline 1 ounce & 50 feet of drill & Onion Sets \\
\hline $1 " 1$ & 50 “ “" “ & Parsley \\
\hline 1 quart & $100 "$ " & Pumpkin \\
\hline & 150 hills & Parsnip \\
\hline 1 ounce & 100 feet of drill & Peas \\
\hline 1 " & 50 hills & Radish \\
\hline 1 quart & $200 "$ & Spinach \\
\hline 1 ounce & 100 feet of drill & Squash, Early \\
\hline $\begin{array}{lll}1 & \text { " } \\
1 & \text { " }\end{array}$ & 30 hills & Squash, Late \\
\hline “" & $60 " “$ & Turnip \\
\hline & $100 \mathrm{fe}$ & \\
\hline
\end{tabular}

40 feet of drill

20 hills

100 feet of drill

100 " " "

100 " " "

50 “" " "

50 “" “ "

15 “ ، “ ، 


\title{
A Descriptive List of
}

\section{CHOICE FLOWER SEEDS}

\author{
With General Directions For Cultivation
}

A rich, sandy loam is the best for most flowering plants. The soil of a good garden should be deep, well pulverized, and if fertilizers are used they should be thoroughly mixed with the soil.

It is best in practically all instances except hardy annuals to start the seed in boxes, preferably a box about $18 \mathrm{x} 24$ inches and 4 inches deep, using very sandy soil with leaf-mold that will not bake, and provide for drainage by boring some holes in the bottom of the box. It is best not to put any fertilizer in the seed box, since it is only necessary to bring the plants to the third or fourth leaf, when they should be pricked out and reset in another box, in which the soil should be loam mixed with leaf-mold. It is important that the plant be of good size, strong and sturdy, when finally transplanted in the garden.

If the seed be sown directly in the garden, it should be sown in the spring after the soil is well worked and fertilized. When up, the plants must be thinned from two to twelve inches, depending on the variety, otherwise they will be weak and spindling. It is a mistake to leave plants too thick. A common mistake in sowing flower as well as other seeds is covering too deep. As a general rule, cover only to the depth of the thickness of the seeds, or with medium-sized seeds, like Balsams, Zinnias, etc., half an inch or less is the proper depth. Such fine seeds as Portulaca, Nicotiana, etc., need only to be pressed into the soil with a piece of board or palm of the hand. Always press the earth down firmly after sowing all flower seeds, else there is danger of their drying up before the roots can get firm hold of the soil. Seeds of the hardier annuals may be sown where they are to grow; but, as a rule, it is preferable to transplant, as the plants are generally stronger and stand the drought better. During very dry weather, and when the seedlings are first set out, they should be watered frequently. Provide some support for all such annuals as require it.

The weeds should be kept down and the ground loosened often, so that the plants will receive the full benefit of the rains and dews, which they will not if the ground is allowed to become hard and baked.

ABUTILON (Flowering Maple). Free-flowering, perennial shrubs of strong growth and easy cultivation; drooping, bell-shaped flowers of various

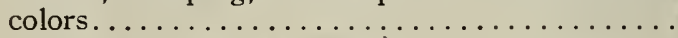

ACONITUM (Monk's Head). Hardy perennial, with helmet-shaped flowers; growing in any good garden soil. Thrives best when planted among shrubbery or in shady situations. 4 feet. Nappellus. Large, blue .............. Nappellus White. Large IVhite.......... Finest Mixed. $1 / 4$ oz. $35 \mathrm{c}$.

ACROCLINIUM. A half-hardy annual, bearing white and rose-colored flowers which are used when dried for winter bouquets. $1 \mathrm{I} / 2$ feet.

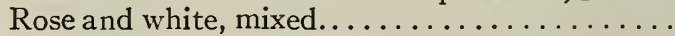

AGERATUM. A beautiful, hardy annual. The flowers, which are produced in clusters, are very attractive in the garden and are very useful for bouquets.

Little Blue Star. Bright blue flowers, 6 inches Blue Perfection. Dark Blue. $11 / 2$ feet.....

ALYSSUM. A fragrant, hardy annual, bearing spikes of small, white flowers in great profusion throughout the summer and autumn. Useful for borders and for cutting.

Sweet Alyssum. Flowers small and sweet. Oz. 25c..

Little Dorrit. Pure white, very dwarf and sweet scented $\ldots \ldots \ldots \ldots \ldots \ldots \ldots \ldots$ Little Gem. Pure white. 6 inches........... Saxatile Compactum. Perennial, 10 inches high, compact habit, yellow flowers.........

AMARANTHUS. Hardy annuals, grown especially for their brilliant foliage.

Tricolor (Joseph's Coat). The plant is 3 feet high, with brilliant leaves in variegated red, yellow, green, etc.

AMMOBIUM (Alatum Grandiflorum). A hardy annual, with white everlasting flowers; useful as bouquets and as dried flowers.

AMPELOPSIS VEITCHII (Boston Ivy). The best hardy vine for covering brick or stone buildings, etc.; foliage turning to scarlet in the autumn.

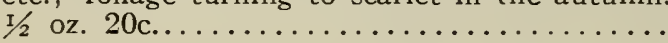

er Pkt.

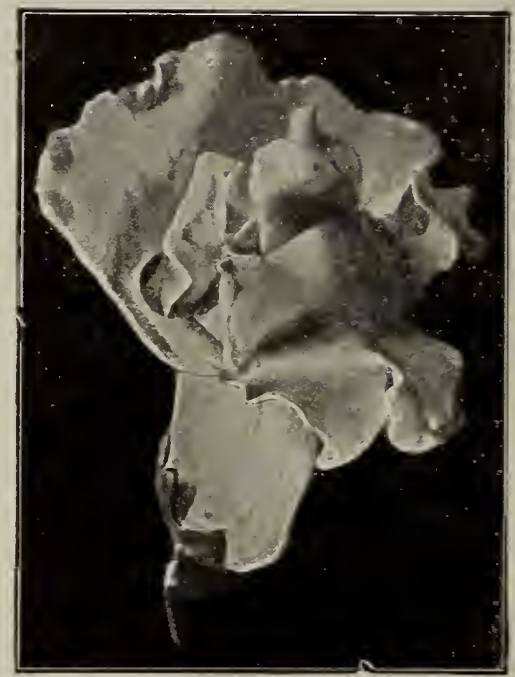

ANTIRRHINIUM (SNAPDRAGON)

ANTIRRHINIUM (Snapdragon). A half-hardy perennial, easily raised from seed. Bloom profusely the first season from midsummer till fall.

\section{TALL，LARGE，FLOWERING VARIETIES}

Defiance. Brilliant scarlet. $1 / 4 \mathrm{oz} .35 \mathrm{c}$ Per Pkt.

Fire King. Orange-scarlet, with white throat

Firefly. Scarlet and white $1 / 4 \mathrm{oz} .35 \mathrm{c}$.

Galathee. Crimson and white...... $1 / 4$ oz. $35 \mathrm{c}$.

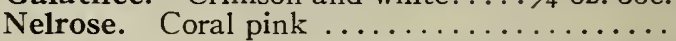

Othello (New). A very distinct large-flowering Snapdragon which produces flowers of a rich, dark maroon color.......... I/4 oz. 75c. Silver Pink. Delicate rosy pink ......... Victoria. Pure white......... $1 / 4$ oz. $25 \mathrm{c}$. Venus (New). Delicate Pink, with white throat............... ${ }^{\frac{1}{8}}$ oz. 35c. Large Yellow............. . . . . oz. 35c.

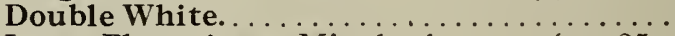
Large Flowering. Mixed colors .. $1 / 4$ oz. $25 \mathrm{c}$. Semi Dwarf. Finest Mixed....... . 1/4 oz. 25c. 


\section{ASTERS}

A popular half-hardy annual produced in a great variety of classes and an almost endless number of colors. The tallest varieties grow about two feet high and some varieties of dwarfs are not six inches high. The best method of culture is to sow the seed in boxes in March or April. Cover the seeds about one-fourth inch deep with rich, light soil, and when the plants have three or four leaves transplant about 15 inches apart each way. The seed can be sown in rows where the plants are to remain, thinning them from six to twelve inches apart, according to variety. One of the best annuals for cut flowers.

Vick's Lavender and Purple Rochesters. New colors in this splendid type of aster. The flowers are of immense size, often 5 inches across, with petals that are very long and narrow, and gracefully recurved.

Vick's Lavender Rochester. A clear light lavender color ............\$0.15

Vick's Purple Rochester. A deep rich

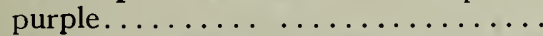

Vick's Non-lateral Lavender Pink. The entire strength of the plant is given to the production of six or eight immense, wonderfully double flowers which are held erect at all times by the stiff, semi-upright stems ..........

Vick's White Perfection. The finest mid-season White Aster in cultivation. The plants are extremely vigorous, with unusually broad dark green leaves and stout stems. They carry about twelve large flowers on long stems free from side branches...

Vick's Pink Enchantress. The plants are tall and strong, and the flowers are the size of those of the largest Branching Asters. The color is that of the popular "Pink Enchantress" Carnation. This color, although very delicate, does

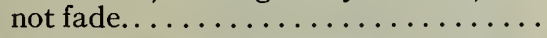

Vick's Imperial Daybreak. Flowers very large and double; color a shell pink. The plant flowers very early and is a continuous free bloomer. Height 15 to 20 inches.......... 10

Vick's Imperial Purity. Similar to Daybreak in form and habit of growth; the blooms

p are pure white.................\$0.10

Vick's Imperial Lavender. The form of the flower the habit of the plant and the time of blooming are identical with Daybreak, but the color is a delicate lavender

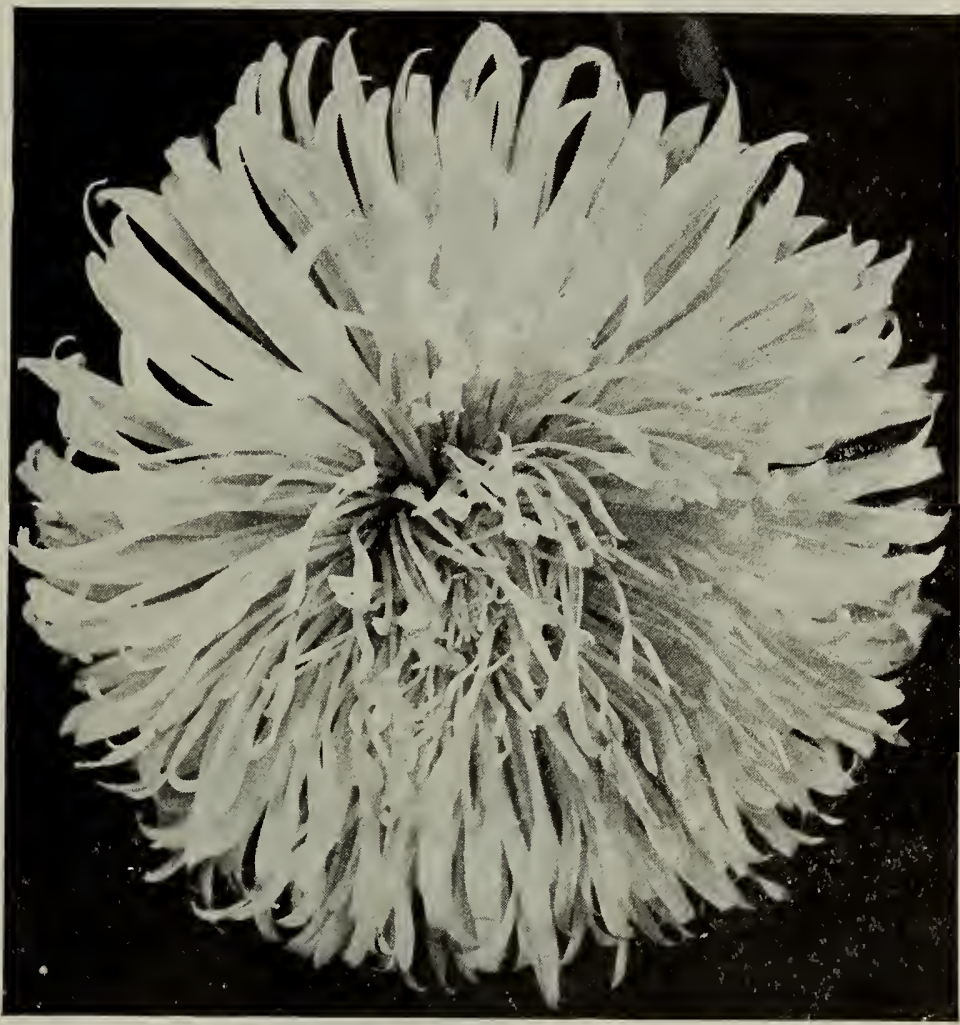

Vick's Imperial Yellow. A pale lemon yellow,

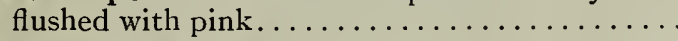

Vick's Violet King. In form the flower petals somewhat resemble the quilled varieties, but are much larger and broader. The bloom is round, full and very large, many of the flowers measuring from four to five inches in diameter. Its color is a soft violet-lilac...............

Vick's Cardinal. This variety is particularly adapted for bedding, owing to its free-blooming qualities and brilliant coloring..........

Vick's Royal Purple. A variety of dwarf growth; flowers large, color a rich shade of purple......

Crego's Giant. One of the finest varieties of asters, flowers very large, often five inches across, with long, stout stems. Keep longer in good condition when cut than any other variety. Bloom August and September.

White $\ldots \ldots \ldots \ldots \ldots \ldots \ldots \ldots \ldots \ldots \ldots \ldots \ldots . .10$

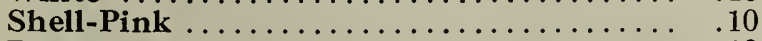

Rose ....................... 10

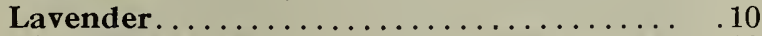

All Colors Mixed............

Semple's Branching. The plant grows 18 inches high. The blossoms, which are large and fullpetalled, are borne on long stems or branches; flowers late in the autumn.

Lavender

Shell-Pink

$\$ 0.10$

Pure White.

Finest Mixed............

Single Japanese. This new variety of Single Asters bears large, star-shaped flowers. The yellow central disk is encircled by a wreath of long, quilled petals. Of branching habits, the plants throw up a large number of strong side stocks from the base of the main stem.

White

Delicate Rose

Truffaut's Peony-Flowered Perfection. This variety has brilliant and showy assortment of colors. Flowers, medium size; plant about 18 inches high.

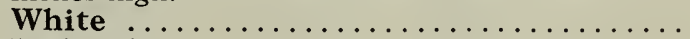

Light Blue $\quad \ldots \ldots \ldots \ldots \ldots \ldots \ldots \ldots \ldots \ldots \ldots \ldots$

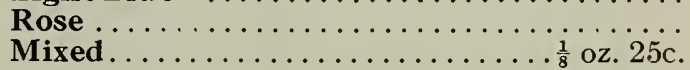

Giant Comet. A fine variety, with large blossoms. White ................

Finest Mixed................ 


\section{ASTERS - Continued}

Queen of the Market. One of the earliestblooming varieties. The plants are about 1 foot high, bearing from ten to fifteen finely formed flowers on long and graceful stems.

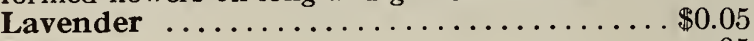

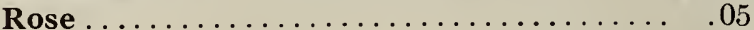

White $\ldots \ldots \ldots \ldots \ldots \ldots \ldots \ldots \ldots \ldots \ldots \ldots \ldots . .05$

Mixed. Aill colors..............

Dwarf Chyrsanthemum Flowered.

Finest Mixed............... $\frac{1}{8}$ oz. 25c. .10

Ball or Jewel. A dwarf, fall-flowering variety; flowers quite round.

Fine Mixed.............. $\frac{1}{8}$ oz. 20c.

Quilled German. A showy class from $11 / 2$ to 2 feet high, with quilled flowers and branching habit. Mixed colors ............... $\frac{1}{8}$ oz. 20c.

Cocardeau or Crown. A variety producing very showy and bright-colored flowers with white centers; $1 \mathrm{I} / 2$ feet.

Finest Mixed............. $\frac{1}{8}$ oz. 20c.

Mixed Asters. Tall varieties, mixed..... $\frac{1}{8}$ oz. 15c.

Asparagus Plumosus Nanus. A tender perennial for greenhouse or potted plant use, with long, fine, feathery foliage ............. Sprengeri. Excellent plants for table decoration $\ldots \ldots \ldots \ldots \ldots \ldots \ldots \ldots \ldots \ldots \ldots$

As perula Azurea Setosa. Sweet-scented annual with light blue flowers. It will grow in shaded places; $1 \mathrm{ft} . \ldots \ldots \ldots \ldots \ldots \ldots \mathrm{I} / 4 \mathrm{oz} .15 \mathrm{c}$

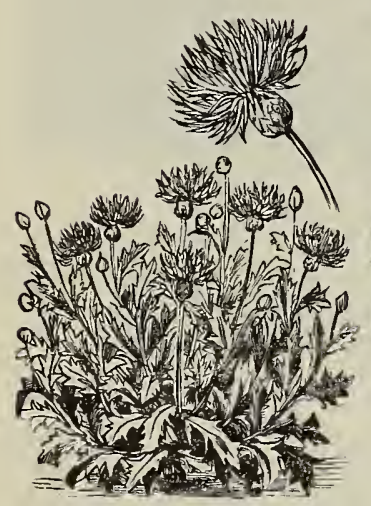

BACHELOR'S BUTTON

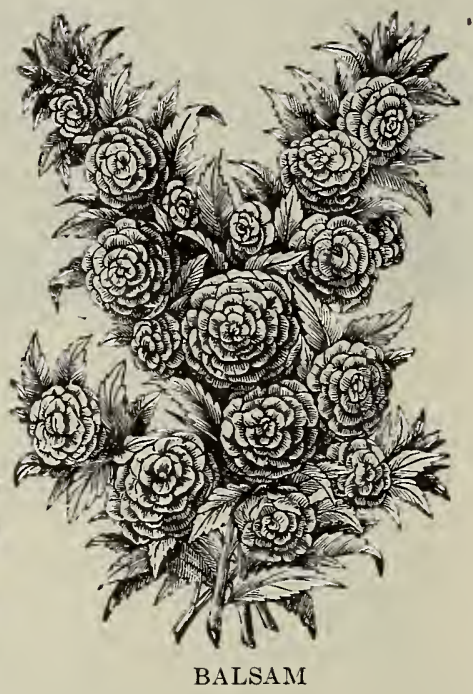

BALSAM
BACHELOR'S BUTTON. Hardy annual of easy culture, one of the most attractive of all the oldfashioned flowers. Sow the seed where it is to remain and thin to six inches.

Emperor William. Fine dark blue....

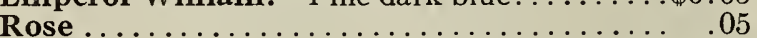

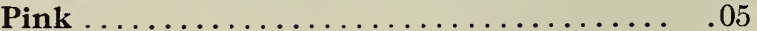

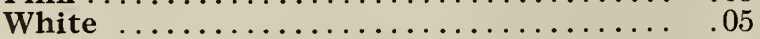

Finest Mixed ................ $1 / 2$ oz. 10c. .05

Semi-double Mixed Colors............ . 05

BALSAM. A favorite garden flower, producing masses of beautiful, brilliant-colored, double flowers of easy culture; succeeds in a good rich soil; set the plants one foot apart; tender annuals; 2 feet................. $\frac{1}{8}$ oz. $25 \mathrm{c}$. Double Camellia-Flowered. Finest mixed.. Double Rose-Flowered. Finest Mixed.

White Perfection. Double pure white. . . . . .
BARTONIA AUREA. A free-blooming, showy plant with large, golden-yellow flowers; 18 inches ......................\$0.05

B E A N S , Flowering. Popular ornamental climbers, 6 to 8 feet.

Butterfly Runner $\quad \ldots \ldots \ldots \ldots \mathrm{r} / 2 \mathrm{pt} .15 \mathrm{c}$.

Scarlet Runner. ............ . $1 / 2$ pt. 15c.

White Runner............. I/2 pt. 15c.

BEGONIA SEMPERFLORENS. A variety adapted for house or outdoor culture; easily grown. Seed sown in February or March makes fine plants for bedding out in June. Height 8 to 12 inches.

Choicest Mixed..................

BEGONIA, Tuberous Rooted Varieties. Very popular and showy plants for summer decoration or window gardening. Sow the seed indoors in February or March.

Single Choice Mixed.

Double Choice Mixed.

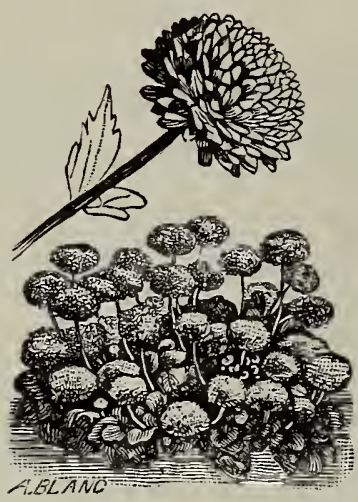

BELLIS PERENNIS

BELLIS PERENNIS (Double Daisy). Sow the seed very early. The flowers are abundant in early spring and may be continued later by the use of water. Set about six inches apart in a cool border. Perennial.

Longfellow. Large, rose-colored flowers. $\frac{1}{8}$

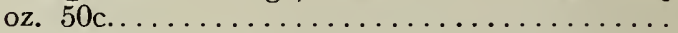
Snowball. Large, double, pure white, with long, stiff stems............. $\frac{1}{8}$ oz. $50 \mathrm{c}$. Finest Mixed.............. $\frac{1}{8}$ oz. $25 \mathrm{c}$.

SHASTA DAISY. Fine, hardy perennial, producing large flowers which are very desirable for cutting. Height 2 feet.

Alaska. Pure white. Extra...........

BROWALLIA. Very handsome, free-flowering plants. $1 \frac{1}{2}$ feet high.

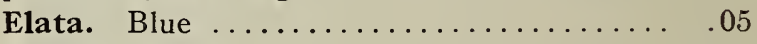

Alba. White $\ldots \ldots \ldots \ldots \ldots \ldots \ldots \ldots \ldots \ldots . .65$

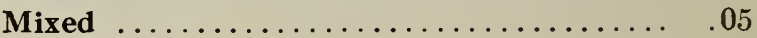

CALCEOLARIA. A tender perennial, used largely in greenhouses and conservatories.

Carter's Victoria Prize. Mixed, all colors... 


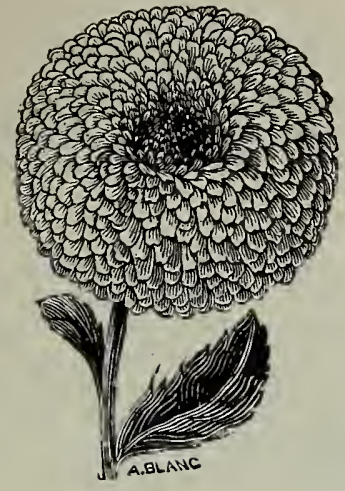

CALENDULA

Per Plit.

CALENDULA. Profuse-blooming, dwarf annuals; of easy culture and flowering until frost.

Meteor. Handsome, double and beautifully striped, the petals having a creamy center edged with orange-yellow. . . . . . . . . . \$0.05

Prince of Orange. Fine orange. Double... . 05

Mixed Varieties............ I $/ 2$ oz. 10c. .05

CALLIOPSIS (or Coreopsis). A hardy annual growing about 2 feet high, valuable for bright bedding effects or for cutting. Blooms from June until September.

Drummondi. Yellow, with maroon center... Cloth of Gold. Flowers golden yellow....... Nigra Speciosa. Dark Maroon........... Mixed. Fine Varieties.......... I/4 oz. 10c.

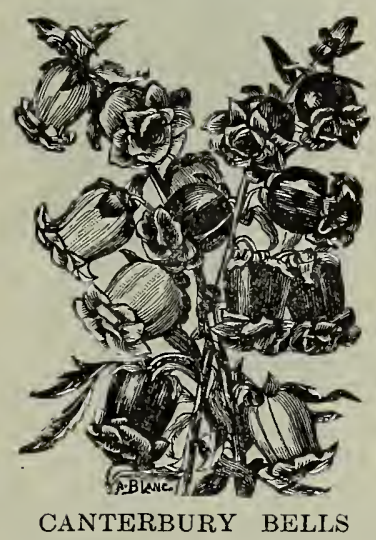

CANTERBURY BELLS. Hardy biennials of rich color and profuse bloom. Succeeds best in light, rich soil and in the fall should be transplanted two feet apart and given some protection in severe winter weather; large bell-shaped flowers which are very effective. Height 2 to 4 feet.

Single Blue.....................

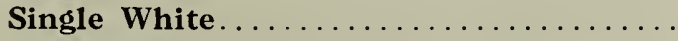

Single Rose. . . . . . . . . . . . . . . . . .

Single, Fine Mixed . . . . . . . . . . $\frac{1}{8}$ oz. 15c.

Double, Fine Mixed. . . . . . . . . $\frac{1}{8}$ oz. 15c.

CANARY BIRD VINE. Half-hardy, climbing annual, bearing an abundance of bright yellow, fringed flowers............ $1 / 2 \mathrm{oz} .15 \mathrm{c}$.
CANDYTUFT. A hardy annual of easy culture and valuable for bedding or massing.

Giant Hyacinth Flowered. Very large heads and long spikes of white flowers. 1 foot. I $/ 2$ oz. $25 \mathrm{c} . \$ 0.05$

Empress. Pure white pyramidal; fine for forc-

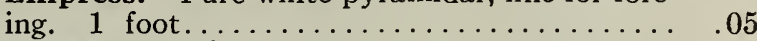

Crimson. 1 foot ................ 05

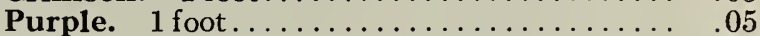

Rose. 1 foot.................... 05

White. 1 foot .................... 05

Finest Mixed. 1 foot.... oz. 15c., $1 / 2$ oz. 10c. $\quad .05$

Little Prince. Dwarf, white. 6 inches..... .10

CANNA. The Canna will bloom from seed the first year if the seed is sown early. Seeds should be soaked for twenty-four hours in warm water before sowing.

Crozy's Varieties. Mixed. New large-flowered and free-blooming sorts...... $1 / 2$ oz. 20c.

CATCHFLY. Free-blooming, hardy plants of easiest cultivation, useful for beds and borders. 6 inches.

Mixed Colors ......................

CENTAUREA (Dusty Miller). Half-hardy perennial, used for borders or edgings.

Candidissima. Silvery white foliage, deeply cut; about 1 foot high. ................. Gymnocarpa. Leaves silver gray, with graceful, drooping habit. $11 / 2$ feet............

CHRYSANTHEMUM (Annual). Summerblooming annuals, growing 12 to 18 inches high, very effective for beds or cut blooms.

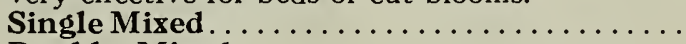

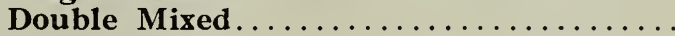

CINERARIA. Magnificent flowering plant for spring decoration for the conservatory or window garden. The flowers measure 2 to 3 inches across; are of white, blue, violet and crimson shades.

Carter's Brilliant Prize. Large flowering,

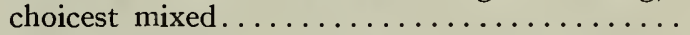

CLARKIA. Beautiful, hardy annuals with rosecolored, white and purple flowers in very brilliant shades. About $1 \frac{1}{2}$ to 2 feet high and profuse bloomers.

Single Mixed .............. I/2 oz. 15c.

Double Mixed.............. I oz. 15c.

COBAEA. A rapid-growing climber, with handsome foliage and large, bell-shaped flowers. half-hardy perennial. $20 \mathrm{ft}$.

Scandens. Purple ............ $\frac{1}{8}$ oz. 15c.

COCKSCOMB. Very popular annuals of the easiest culture, producing large, ornamental comb-like heads; useful both for summer bedding and pot plants.

Glasgow Prize. Brilliant, deep purplish-red combs, dark foliage. Height about 1 foot . . . . . Finest Dwarf Mixed. $\ldots . . \ldots \ldots$

COLEUS. A tender perennial, growing about 10 to 18 inches high, and grown for its beautiful, bright-colored, velvety leaves.

Mixed Hybrids. Finest Mixed varieties..... .

COLUMBINE. Well-known hardy perennials, bearing in great profusion, through May and June, exquisite flowers greatly varied in coloring; of easy culture, thriving best in dry soil and growing well in partial shade. 1 to 3 feet. Single, Mixed Colors ................ Double, Mixed Colors . . . . . . . . . . . 
GONVOLVULUS major (Morning Glory). A handsome, showy climber of easy culture and suitable for covering windows, trellises, etc. The flowers are most brilliant in the morning and run through many shades from white to dark blue, red and striped. Hardy annuals 10 feet high.

Finest Mixed....... 1/4 lb. 20c., 1 oz. 10c. $\$ 0.05$

Imperial Japanese. Handsome flowers of gigantic size and in colors ranging from snow white to carmine, through every shade of blue and purple to nearly black, and striped

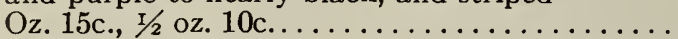

COSMOS. A very effective flowering plant, quite hardy and rapid growing, forming bush-like plants 4 to 6 feet high and covered with large, single, dahlia-like flowers. Start in March and transplant to open ground about June first.

Early Flowering, Mixed Colors . . $1 / 2$ oz. 25c. "، $\quad$ " $\quad$ White $\ldots \ldots \ldots \ldots \ldots 1 / 2$ oz. $25 \mathrm{c}$. "، $\quad$ "6 $\quad$ Pink .......... Grimson $\ldots \ldots \ldots$ oz. $25 \mathrm{c}$.

Lady Lenox. Late Flowering. Color, shellpink. Plants strong and vigorous, growing 6 to 7 feet high ............

GYCLAMEN. A tender perennial for greenhouses and window gardens. Easily grown from seed. Sow in August or September.

Persicum Giganteum. Large flowers, choice mixed.$\ldots \ldots \ldots \ldots \ldots \ldots \ldots \ldots \ldots \ldots \ldots \ldots \ldots$

CYPRESS VINE. A summer, climbing annual with fine, feathery foliage and pretty, starshaped flowers.

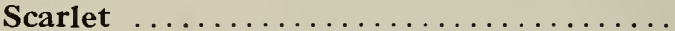

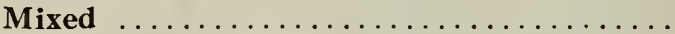

DIANTHUS or Pinks. Hardy biennials that bloom the first season, remaining green all winter and blooming the next year also if lightly protected. Old plants flower the earliest, but as young ones give the largest, finest flowers, sowings are made every year. Seed can be sown under glass in the spring, or in an open, sheltered bed. The seedlings are easily transplanted. Average height, 1 foot.

Chinese Double Mixed. A mixture of brilliant coloring and marking................

Heddewigi Luteolus. A novelty producing double, light yellow flowers. Hardy annual...

Heddewigi. Very large-flowering, double, choicest mixed, extra fine strain..........

Double Clove. A hardy perennial, pink, very fragrant, choice colors.................

Marguerite, Giant Mixed. The flowers are of brilliant colors, ranging through many beautiful shades of red, pink, white, variegated, etc.; they are of perfect form and large size. Those sown in the spring commence flowering in early summer and continue to bloom until checked by frost...................

Marguerite. Dark red..............

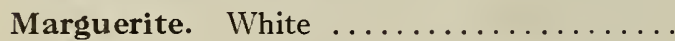

Carter's Choice Double Mixed Carnation. Beautiful variety, producing very double flowers of various shades and colors. Seed saved from choicest double flowers. ..............

\section{DIANTHUS - Continued}

Plumarius (Grass Pink, or Pheasant-eye Pink). A single hardy Pink, with fringededged, fragrant flowers, mixed colors ......\$0.0.5

DAHLIA. A popular late summer and autumn flowering plant. Is grown from seed or propagated from the bulbous roots. The seed may be planted early in the hotbed and the plants set out in May after all danger of frost is over. By sowing the seed early the plants may be made to bloom the first year.

Double Mixed...................... 10

Single Mixed ....................... .10

DATURA. Large, strong-growing plants, with large, trumpet-shaped flowers. 3 feet.

Finest Mixed.

DELPHINIUM. Hardy perennials, with splendid flowers, very showy and indispensible for hardy beds or borders.

Formosum. Deep blue............... .0

Double Hybrids, Finest Mixed . . . . . . . . . 10

DRACAENA. Ornamental plants for vases, baskets and house decorations.

Indivisa. Narrow green leaves............ . 10

Veitchi. Variegated foliage, brilliant colors... . .15

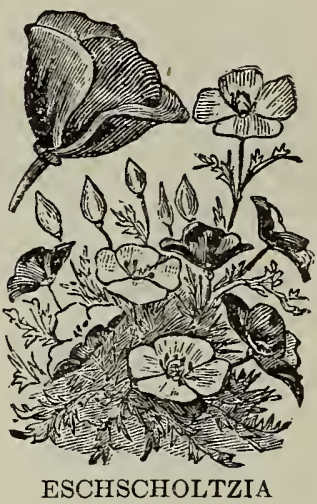

FEVERFEW. Free-flowering annuals for bed, borders and pot culture.

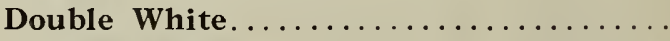
Golden Feather. Very popular for edgings.

ESGHSCHOLTZIA (California Poppy). The foliage is finely cut and has a blush tinge, delicate and very attractive. The large, handsome flowers, two inches or more in diameter, are produced in great profusion all summer. Seeds can be sown where the plants are to bloom. Hardy annual; height, 1 foot.

Californica. Deep yellow, orange center. Oz. $15 \mathrm{c} \ldots \ldots \ldots \ldots \ldots \ldots \ldots \ldots \ldots \ldots \ldots . . \ldots \ldots$

Mandarin. Deep orange............. 05

White ....................... 05

Carmine King. Carmine-rose........... . 10

Mixed..................... 15z. .05

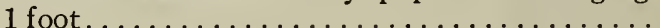




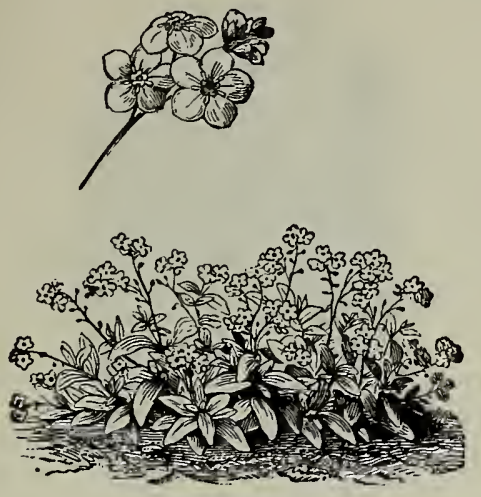

FORGET-ME-NOT
Per Pkt.

FORGET-ME-NOT. A hardy perennial, growing 6 to 12 inches high. Small, star-like flowers are borne in clusters on long stems. The plant is of easy culture and blooms the first year if seed is sown early.

Indigo Blue. Large, dark blue flowers.

$\frac{1}{8}$ oz. 15 c. . . . . . . . . . . . . . . $\$ 0.05$

Victoria. Large flowers, bright azure blue; dwarf habit; fine for borders ........ $\frac{1}{8}$ oz. 15c. Fine Mixed ............... $\frac{1}{8}$ oz. 15c.

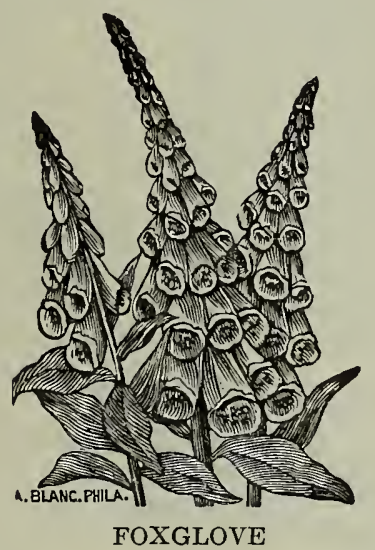

FOXGLOVE. The Foxgloves are highly ornamental plants. They are fine for the mixed border or planted singly in half-shady places near a walk or drive. The spikes of flowers are often two feet in length, containing scores of the prettily-spotted, thimble-shaped flowers. Perfectly hardy. Sow seed in spring in the garden and transplant as desired. Perennial. Mixed varieties............... $1 / 4$ oz. 20c.

FRENCH HONEYSUCKLE (Hedysarum). Very handsome, free-flowering plants; well adapted for borders or rock-work. Hardy perennial; 4 feet high.

Scarlet

Album.

GAILLARDIA. Very showy plants with brilliant flowers. Hardy annuals and perennials, 1 to $1 \pi / 2$ feet high.

Double Mixed. Annual......... I/4 oz. 20c. Finest Mixed. Perennial.......... . . oz. 15c.

GLOBE AMARANTH. Globe-shaped, everlasting flowers. If cut when well matured, will retain their beauty through the winter. Tender annuals; 12 to 18 inches high.

Fine Mixed.
GLOXINIA. Greenhouse perennial plants, producPer Pkt. ing soft, velvety green leaves and rich, beautifully colored flowers.

Carter's Invincible Prize. Superb mixture . . $\$ 0.25$

GODETIA. Beautiful garden plants, having large, delicately shaded blossoms. Easily cultivated in garden soil. Hardy annual; about 1 foot high.

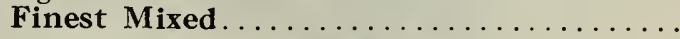

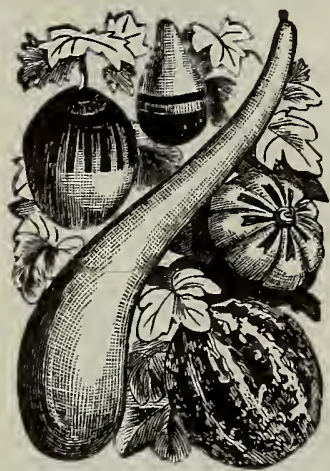

GOURDS

GOURDS. Ornamental, rapid-growing, trailing annuals, with curiously-shaped, highly-colored fruits. Cultivate the same as melons or squashes; 10 to 20 feet.

Dipper or Calabash . . . . . . . . . . . . . .05

Hercules' Club. Club-shaped. 4 feet long.. .05

Egg-shaped. Fruit white like an egg...... .05

Orange-shaped (Mock Orange).......... .05

Bottle-shaped ............... 05

Pear-shaped. Striped, very showy....... . 05

Luffa (Dish-cloth or Bonnet Gourd) ....... . 05

Sugar Trough $\ldots \ldots \ldots \ldots \ldots \ldots \ldots \ldots \ldots . . \ldots 5$

Mixed Varieties............. 1/2 oz. 15c. .05

GRASSES (Ornamental). Ornamental grasses serve the double purpose of rendering the mixed flower bed or border attractive during the summer and for the use of the spikes or panicles in a dried state in winter bouquets.

Avena Sterilis (Animated Oats). Drooping, very graceful. Annual. 2 feet... . . . . . . . . . .

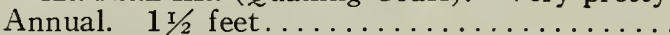
Coix Lacryma (Job's Tears). Grows 2 feet

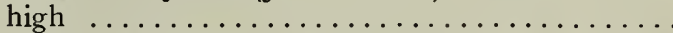

Eulalia Japonica. One of the most beautiful of the tall-growing grasses. 5 feet............ Gynerium Argenteum (Pampas Grass). The finest ornamental grass in cultivation. Half-hardy perennial. 10 feet............. Hordeum Jubatum (Squirrel Tail Grass). Annual. ................................ Stipa Pennata (Feather Grass). One of the
prettiest and most interesting. Perennial. 2 feet $\ldots \ldots \ldots \ldots \ldots \ldots \ldots \ldots \ldots \ldots$

GREVILEA ROBUSTA. A graceful, decorative plant with fern-like foliage; excellent for table decoration; easily raised from seed..........

GYPSOPHILIA. Free-flowering, elegant plants, succeeding in any garden soil.

Elegans. A hardy annual, large white flowers. Paniculata (Baby's Breath). Fine for bouquets; white flowers. Perennial............

5

5

5




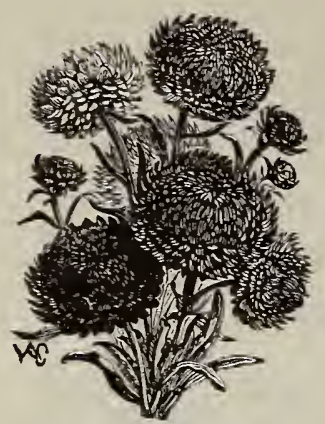

HELICHRYSUM

HELICHRYSUM. The well-known E Flower. It is everywhere prized for winter decoration. Hardy annual.

Finest Double Mixed

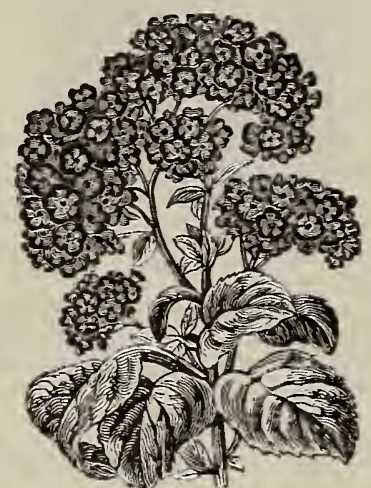

HELIOTROPE

HELIOTROPE. This class of plants is one of the finest for cutting, as the delicious fragrance of all the varieties is very durable. For the same reason they make excellent house plants. Seed sown early in the spring in the house will make fine plants for summer bedding.

Queen Marguerite. Bears immense clusters of large deep dark-blue flowers. Very fragrant. .

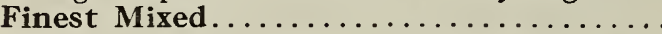

HONESTY (Satin Flower). The flat, silvery seed pods are used for winter decoration. Very handsome, free-flowering. Hardy biennial. 2

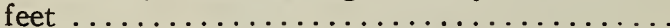

HUMULUS JAPONICUS (Japanese Hop). Fastgrowing, annual climber. 12 feet............

HYACINTH BEAN. Tender, climbing annual. Grows rapidly and is valuable for covering a trellis. The shining purple seed pods are very ornamental. Tender annual, growing 6 to 8 feet.

Finest Mixed.................. 15.

ICE PLANT (Mesembryanthemum Crystallinum). A pretty, half-hardy annual, with delicate, succulent, almost transparent branches and leaves. Useful for baskets, vase work, and

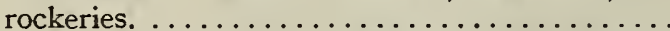

JACOBAEA (Senecio). A showy, free-flowering hardy annual. It produces in great profusion branching spikes of bright Cineraria-like double flowers one and one-half inches in diameter. Excellent for bouquets. Mixed

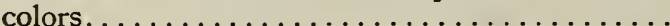

KOCHIA TRICOPHYLLA (Summer Cypress). A splendid ornamental annual plant, forming dense oval bushes 2 to $21 / 2$ feet high, of small, feathery, light green foliage. As summer advances, this changes to a carmine hue and finally to a fiery red. A very attractive plant.
$\$ 0.05$

Per Pkt.

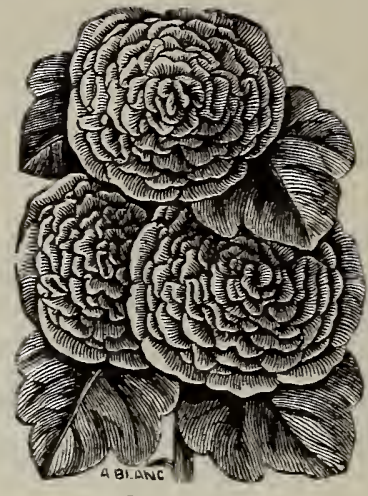

HOLLYHOCK

EVERBLOOMING ANNUAL HOLLYHOCK.

Hardy annuals, blooming the first season.

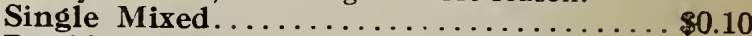

Double Mixed .......................... 10

Allegheny. A semi-double, fringed variety.

Finest Mixed............... I/4 oz. $25 \mathrm{c}$

HOLL YHOCK. (Perennial) Plants of upright, stately growth, 5 to 8 feet high. The double varieties are the most desirable. Very effective when planted in long rows with a background of shrubbery.

Ghater's Double Grimson........ $\frac{1}{8}$ oz. 30c. .10

Ghater's Double Pink............ $\frac{1}{8}$ oz. 30c. $\quad .10$

Chater's Double Yellow............ $1 \frac{1}{8}$ oz. 30c. $\quad .10$

Chater's Double White........... $\frac{1}{8}$ oz. 30c. $\quad .10$

Ghater's Double Rose.............. oz. 30c. .10

Ghater's Double Scarlet. . . . . . . . . oz. 30c. $\quad .10$

Chater's Double Mixed............ $\frac{1}{8}$ oz. 30c. $\quad .10$

Finest Mixed. Single........... 1/4 oz. 15c. .10

LANTANA. Very rapid-growing, free-flowering plants that bloom through the latter part of summer and autumn. The plants form small shrubs, producing in abundance clusters of single, fragrant flowers that continually change color.

Finest French Hybrids Mixed.... . 1/4 oz. 20c.

LARKSPUR. Very ornamental plants, producing, in great variety of form and colors, some of the most beautiful flowers in cultivation.

Double Dwarf Rocket. 1 foot in height. Mixed colors............... 1/4 oz. 10c Stock-Flowered. Double, branching; fine for cutting. 2 feet. Mixed colors...... I $/ 4$ oz. $10 \mathrm{c}$.

LAVATERA (Mallow). Beautiful hardy annuals covered the entire summer with saucer-shaped flowers. The seed may be sown where they are to bloom. Height 2 to 3 feet.

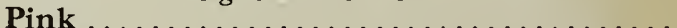

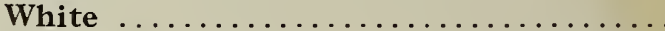

Semi-Dwarf Mixed .......... $1 / 4$ oz. $15 \mathrm{c}$

LAVENDER. Chiefly cultivated for the delicious and lasting fragrance of its flowers; succeeds in any common garden soil. Perennial $1 / 4 \mathrm{oz} .15 \mathrm{c}$.

LINARIA Cymbalaria (Kenilworth Ivy). A charming, neat, hardy, perennial trailing plant, suitable for baskets, vases and rock work. Lavender and Purple....................

LINUM Grandiflorum Rubrum (Scarlet Flax). A beautiful and effective plant of slender and delicate growth, having a profusion of bright flowers. Hardy annual; about $11 / 2$ feet high...

LOBELIA. The dwarf varieties are very useful for edging, and the trailing varieties for hanging baskets and window-boxes.

Erinus gracilis. Blue trailing..... $\frac{1}{8}$ oz. 15c. White Gem. Snow-white flowers..... $\frac{1}{8}$ oz. 15c. Crystal Palace Compacta. 6 inches. Dark blue bedding variety............ $\frac{1}{8}$ oz. $40 c$. 10 


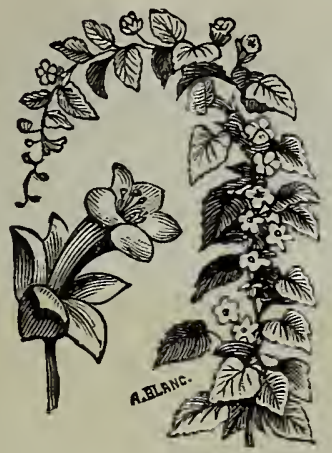

LOPHOSPERMLIM

LOPHOSPERMUM SCANDENS. An ornamental annual climber, growing 10 to 12 feet long, with showy, purplish-rose blossoms resembling Foxgloves ............................... $\$ 0.10$

LOVE-IN-A-MIST. A hardy annual, 1 foot high, with finely cut foliage. Oddly shaped blossoms in blue and white, and curious seed pods. Of easy culture.

Mixed. Blue and white shades............

LOVE LIES BLEEDING. Light yellowish green foliage; long, drooping, crimson flower spikes. Plant 3 to 4 feet high. Hardy annual. ........

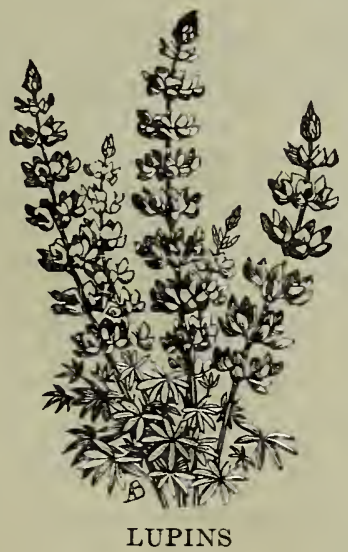

MARIGOLD (Tagetes). A hardy annual plant, in dwarf and tall varieties, growing from 6 inches to 2 feet high: foliage bright green, deeply cut and graceful. The flowers are various shades of yellow and brown. The tall varieties are very valuable for large bedding or background work, and the dwarf varieties for borders. Seeds can be sown in a cold frame or in the open border, and the plants transplanted late in the spring to where they are to remain.

\section{DOUBLE AFRICAN VARIETIES}

Orange Quilled. A double variety with quilled petals; flowers showy, bloom very early; $1 / 4 \mathrm{Oz} .15 \mathrm{c}$. $\$ 0.05$ Lemon Queen. Large, lemon-colored flowers. .05 Finest Mixed .................. $1 / 2$ oz. 15c. $\quad .05$ Dwarf Mixed. 1 foot........... $1 / 2$ oz. 15c. .05

\section{FRENCH VARIETIES}

Tall Double Mixed............. I $/ 2$ oz. 15̃c. .05

.10

.05

.05

.05

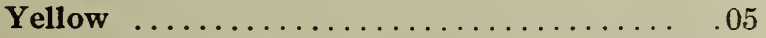

Mixed, All colors............1 oz. 25c. .05

MALOPE. Free-blooming, hardy annuals suitable for mixed borders and fine for cutting. Height 3 feet.

Grandiflora Mixed......................

MARVEL OF PERU. The flowers of this oldfashioned favorite open about four o'clock in the afternoon and fade the next morning. 2 feet high, with bright foliage and fragrant flowers of desirable colors. Set plants 2 feet apart; makes a nice hedge if set a foot apart. Seed should be planted in the open ground where plants are desired.

Mixed colors

oz. $15 \mathrm{c}$. Dwarf Double Mixed............... Gold Striped. Double variety, brilliantly marked and striped. $1 \mathrm{ft} \ldots \ldots \ldots, 1 / 4 \mathrm{oz} .15 \mathrm{c}$. Legion of Honor. A single, dwarf variety, desirable for borders; rich golden-yellow flowers with garnet blotches in center of each petal.....

MAURANDIA. Graceful climber for greenhouse, basket or outdoor purposes. The vines are covered with rich purple, white or rose-colored foxglove-shaped blossoms. Tender perennial, blooming the first season. Usually about 6 feet high.

Fine Mixed ........................

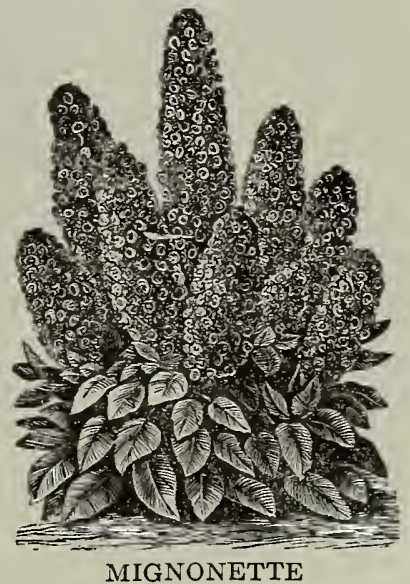

MIGNONETTE (Reseda). A hardy annual, growing 6 to 12 inches high and bearing pyramidal-shaped flower spikes, which are exceedingly fragrant. Grows easily from boxes or sown out in the garden and thinned to 4 or 6 inches. Valuable for potting, for bedding or for border.

Large Flowered. Very sweet...... Oz. 15c. Goliath. A giant, red-flowered variety richly scented .............. $1 / 4$ oz. 50c. Defiance. Immense spikes 12 to 15 inches long, very fragrant........... $1 / 4$ oz. $20 \mathrm{c}$. White Pearl. Long spikes of fragrant white flowers..................

MOONFLOWER. A beautiful vine which grows very rapidly, attaining a height of 50 feet in a season, producing flowers 3 to 4 inches across. Blossoms evenings and cloudy days. Soak the seeds in warm water 24 hours before planting. Grandiflora Alba. Large white flowers.

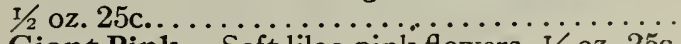


MOURNING BRIDE (Scabiosa). A very showy free-flowering plant, producing a great profusion of beautiful and richly-colored flowers. Beautiful in the garden and excellent for bouquets. 12 to 18 inches high. Annual.

The Fairy. Fine azure-blue............\$0.05

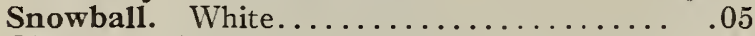

Cherry-Red $\ldots \ldots \ldots \ldots \ldots . \ldots \ldots$

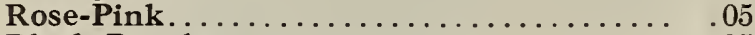

Black-Purple ................... .0. 05

Large Flowering Double, Mixed. . $1 / 4 \mathrm{oz} .20 \mathrm{c}$.

MIMULUS (Monkey Flower). Handsome flowers of easy cultivation. Perennial in the greenhouse, annual in the open air.

Mixed Spotted Varieties. .

MUSK PLANT. Fragrant plant, with small yellow blossoms, spotted lightly with brown.

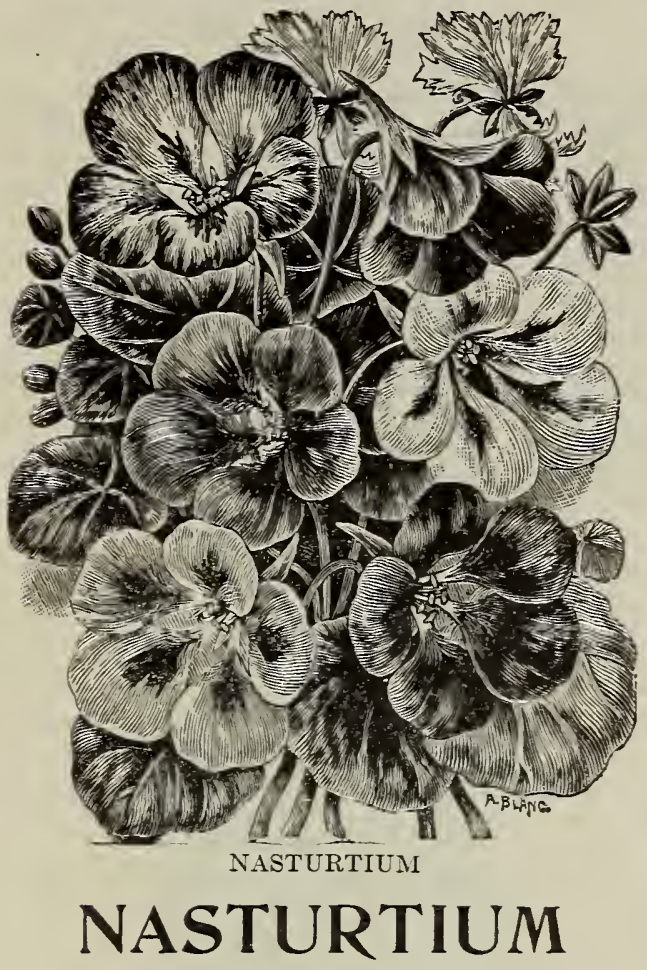

A popular flower which is in constant bloom throughout the season, making a better display than almost any other plant. New colors are being developed, and in our list will be found all the best varieties that have been introduced.

Nasturtiums are of the easiest culture and require very little care after the seed is sown, merely weeding and the seed-balls picked off. If these are permitted to mature, the beauty of the plant is soon lost. Plant the seed one inch deep in moderately good soil. The tall sorts are specially adapted for covering unsightly fences or trailing over rocks and rough ground. Hardy annual.

\section{DWARF VARIETIES}

Of dwarf, compact growth; bloom in two months from sowing and most profusely the whole season. Height 1 foot.

Aurora. Light reddish-orange, veined Pkt. Oz. $\frac{2}{6} \mathrm{lb}$ with carmine............... $.05 \quad .15 \quad .40$

Beauty. Scarlet and yellow...............

Chameleon. Mottled crimson, bronze

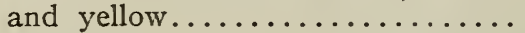

Crimson ............................ Sulphur-yellow spotted with carmine............

Empress of India. A splendid variety, with dark leaves and crimson flowers. ...................

$.05 \quad .15 \quad .40$

$.05 \quad .15 \quad .40$

$.05 \quad .15 \quad .40$

$.05 \quad .15 \quad .40$
DWARF NASTURTIUM-Continued

Golden Cloth. Golden yellow leaves, scarlet flowers................

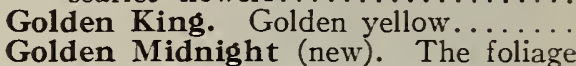

Plst. Oz. 1/4 lb. is a light yellowish-green, while the flowers are of such a dark maroon as to seem almost black.

$.05 \quad .15 \quad .40$

$.05 \quad .15 \quad .50$

King of Tom Thumbs. Dark foliage, scarlet flowers................

King Theodore. Intensely dark crimson or chocolate...............

Lady Bird. Yellow and red spotted....

Pearl. Creamy white...............

Prince Henry. Cream, marbled scarlet Queen of Tom Thumbs. Variegated foliage, bright crimson flowers......

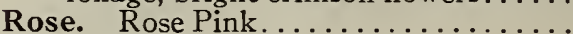

Ruby King. Crimson rose..........

Scarlet. Brilliant scarlet flowers......

Vesuvius. Salmon rose, dark foliage...

Extra Choice Mixture. $1 \mathrm{lb} . \$ 1.00$, 1/4 lb. 30c., 2 oz. 20c., oz. 10c.........

Collection of Six Varieties. Our

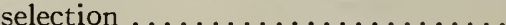

$.10 \quad .20 \quad .50$

$.05 \quad .15 \quad .40$

$\begin{array}{lll}05 & .15 & .40\end{array}$

$\begin{array}{lll}.05 & .15 & .40\end{array}$

$05 \quad .10-40$

$.05 \quad .10 \quad .40$

$\begin{array}{lll}.10 & .25 & .75\end{array}$

$.05 \quad .10 \quad .40$

$\begin{array}{lll}05 & .10 & .40\end{array}$

$\begin{array}{lll}05 & .10 & .40\end{array}$

$.05 \quad .15 \quad .40$

TALL OR CLIMBING VARIETIES

Height, 10 to 12 feet.

Coccineum. Scarlet............. Pkt. Oz. $1 / 4 \mathrm{lb}$.

Dark Crimson.................... $.05 \quad .10 \quad .40$

Dunnett's Orange Deep Orange .... $05-10$

Edward Otto. Brownish lilac........

Hemisphaericum. Orange-salmon and scarlet .......................

King Theodore. Dark red, extra fine.

$05 \quad .10 \quad 40$

$\begin{array}{lll}.05 & .10 & .40\end{array}$

$.05 \quad .10 \quad .40$
low flowers; very large foliage and strong growing; free-blooming......

Pearl. Creamy white..............

Prince Henry. Light yellow, marbled with scarlet. ..............

Scheuerianum. Straw-color, brown

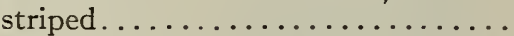

Scheuerianum Coccineum. Scarlet striped.................

Schillingi. Bright yellow, blotched with maroon.

Vesuvius. Brilliant salmon-rose, dark

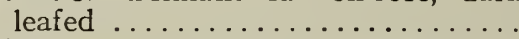

Yellow

Extra Choice Mixture. 1 ib. $\$ 1.00,1 / 4$ lb. 30c., 2 oz. 20c., oz. 10c.........

$.05 \quad .15 \quad .50$

$\begin{array}{lll}.05 & .10 & .40\end{array}$

$05 \quad .10$

.40

$0 \overline{0} \quad .10$

.40

$.05 \quad .10 \quad .40$

$05 \quad .10 \quad .40$

$05 \quad .10 \quad .40$

$05 \quad .10 \quad .40$

Collection of six varieties, our selection

05

.20

NEMOPHILA. A hardy annual, growing about 6 inches high; has small, cup-shaped blossoms in white and shades of blue.

Mixed

Per Pkt.

NEMESIA STRIMOSA SULTÖNI. Free-blooming plants for pot culture and open border. Sow the seed in March under glass or sow out of doors in May. Hardy annual. 1 foot. Blue,

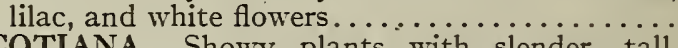

NICOTIANA. Showy plants with slender, tall, flowering stems and fragrant flowers; half-hardy annuals. About 3 feet high.

Affinis. White and very fragrant.........

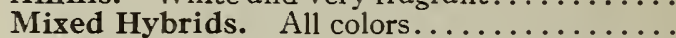
Sanderae. Flowers handsome carmine-red, very fragrant; hardy annual, easily grown .....

NIEREMBERGIA GRACILIS. Tender perennial. Suitable for house culture, or may be treated as a tender annual. Fine for baskets, vases, etc. Light blue, saucer-shaped flowers........ 


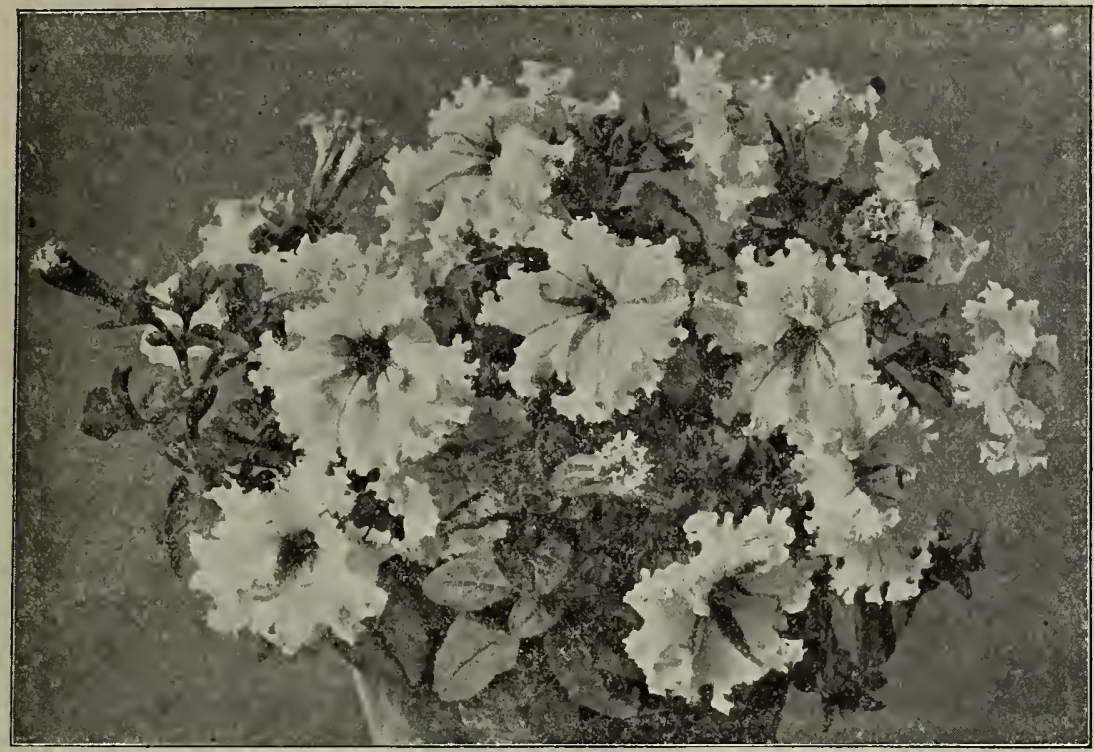

POLYANTHUS (Primula Ela-

Per Pkt. tior). Early spring freeflowering plants, fine for either pot or outdoor culture; hardy perennials; 9 inches.

Fine Mixed.

\section{PANSY}

Pansies thrive best in a moist, shady location and in rich, loamy soil. Seed should be sown in the autumn for early spring blossoms. If sown in the spring, get it in as early as possible, so as to secure flowers during the early rains. Seeds sown in a cool place in May or June, and well watered until up, will produce fall-flowering plants. To have good flowers, the plants must be vigorous and make a rapid growth; use manure liberally.

FRINGED PETUNIA

PETUNIA. Free-flowering and easily cultivated; well-known favorites. They thrive in almost any soil and produce a brilliant array of color throughout the season. The seed will germinate with little difficulty if a reasonable amount of care is used in sowing. Be sure that the soil is well pulverized; then sow the seeds on the surface, pressing them into the soil by using a small, smooth board, and cover very lightly with fine soil.

Per Pkt.

Large-Flowered Single, Fringed. Choice

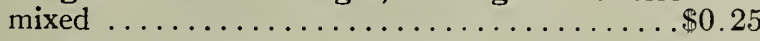

Large-Flowered Double, Fringed. Choice

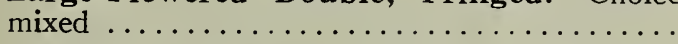
Giants of California. Flowers very large, and deeply fringed. A variety of colors......... Ruffled Giants. Flowers of enormous size, with ruffled edges and brilliant colors. .

Howard's Star. A beautiful free-flowering strain, color a rich, dark crimson, with fivepointed white star $\ldots \ldots \ldots \ldots \ldots \ldots$

Pure White................ 1/4 oz. 25c. Choice Mixed. Striped and blotched. $1 / 4$ oz. $50 \mathrm{c}$. Fine Mixed. All colors......... $1 / 4$ oz. 25c.

PASSION FLOWER (Passiflora). A half-hardy perennial climber, bearing attractive blue fringed flowers. Height 10 to 15 feet........

PRINCE'S FEATHER. Tall spikes of red flowers.

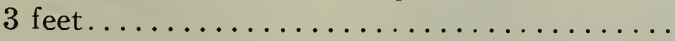

OXALIS. Beautiful small plants suitable for the greenhouse, rock work or outdoor culture, flowering the first year; half-hardy perennials; 9 inches.

White and Pink Mixed

\section{FREE DELIVERY}

To any address in the United States on all Flower Seeds by the packet, ounce, half-pound, and pound.

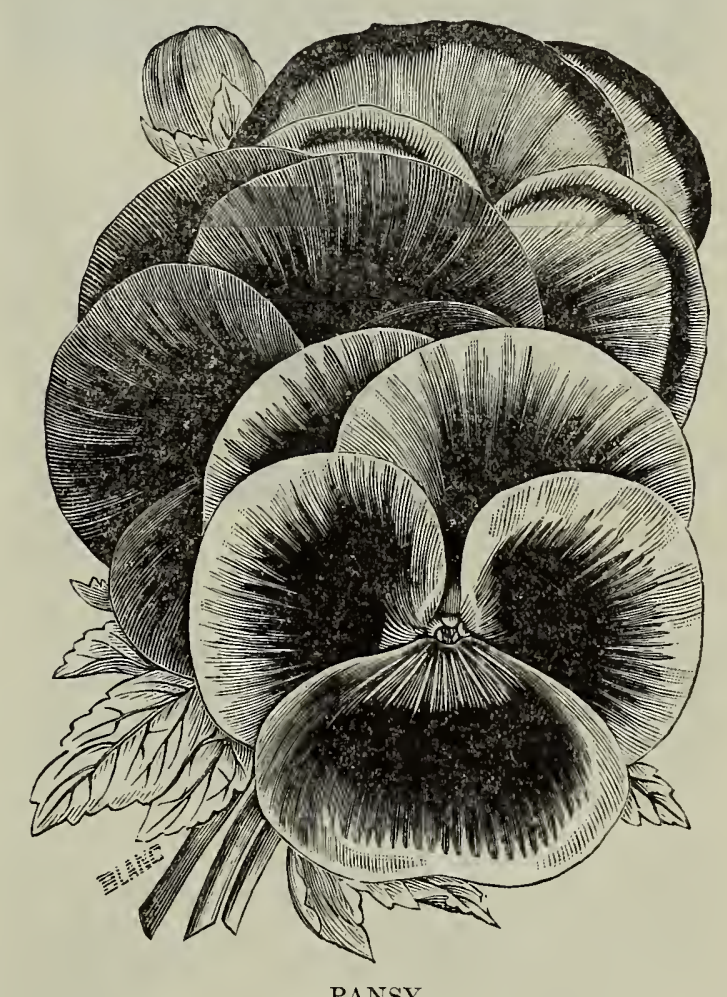

PANSY

Bugnot's Giant Spotted. Very large flowers and beautiful colors............... oz. 50 c. $\$ 0.15$

Odier or Blotched. A very showy variety, with dark blotches on the petals

Parisian Large Flowered Striped. Extra large

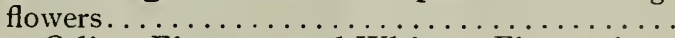

Giant Odier, Five-spotted White. Flowers large and perfectly round; the most attractive of all

Giant Odier, Five-spotted Golden-Yellow. Flowers extra large, perfectly round and exceedingly attractive; the most beautif ul of all yellow

Triumph of the Giants. Immense flowers of great brilliancy. The plants are of rapid growth, and form compact bushes of round shape, with strikingly large, healthy-looking foliage....... 


\section{PANSY - Continued}

Orchid-flowered Mixed. A distinct strain of pansies, showing combinations of colors including terra-cotta, pink, orange, lilac and rose.

$\frac{1}{8}$ oz. $50 \mathrm{c} . \ldots \ldots \ldots \ldots \ldots \ldots \ldots \ldots \ldots \ldots \ldots \ldots .15$

Carter's Peacock. Peacock-blue, white edge.....

Masterpiece. These pansies have a most beautiful combination of rich, velvety coloring and attractive wavy or ruffled petals. This wavy effect gives a graceful appearance rarely seen in pansies....................... $\frac{1}{8}$ oz. $50 \mathrm{c}$.

Adonis. Light blue............. $\frac{1}{8}$ oz. $25 \mathrm{c}$. Atropurpurea. Dark blue ........ $\frac{1}{8}$ oz. 25c. Golden Queen. Pure Yellow ....... $\frac{1}{8}$ oz. 25c. King of the Blacks. Velvety black ... $\frac{1}{8}$ oz. 25c. Lord Beaconsfield. Purple and lavender. $\frac{1}{8}$ oz. $25 \mathrm{c}$. Snowflake. Pure white .......... $\frac{1}{8}$ oz. 35c. "A., S. \& L." Choice mixed........ $\frac{1}{8}$ oz. 75c. Fine Mixed ................ $\frac{1}{8}$ oz. $20 \mathrm{c}$.

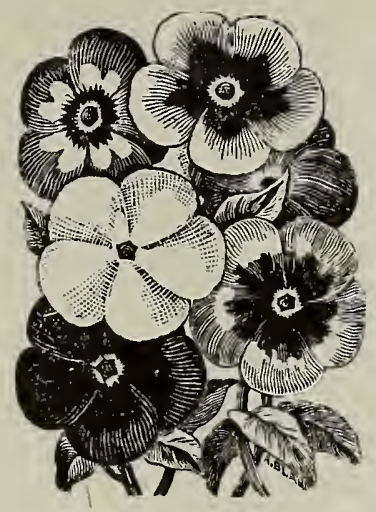

PHLOX DRUMMONDI

POPPY (Papaver). The seed should be sown as early in the spring as possible where they are to remain, as they do not stand transplanting. Thin 6 to 10 inches apart. If left thick the plants will be weak and the blossoms inferior. For beds and borders with a background of green there is nothing finer. The Shirley is beautiful for cutting.

Admiral. White, with broad, brilliant scarlet band, very effective .......... $1 / 4 \mathrm{oz} .20 \mathrm{c} . \$ 0.10$ Shirley. The most beautiful type of poppies, having soft foliage and an immense variety of single blossoms in white, pink, lavender, purple, shades of red and scarlet; the best and most showy of all single poppies........ $1 / 2 \mathrm{oz} .20 \mathrm{c}$.

Danebrog. Large flowers of brilliant scarlet, with a silver spot on each of the petals.

$1 / 4$ oz. 15c............................

Tulip. Dazzling scarlet tulip-shaped flowers. $x / 4$ oz. 15c..........................

\section{DOUBLE ANNUAL POPPIES}

Paeony Flowered. Large, showy flowers, with broad petals; colors range from white to pink, carmine, scarlet, crimson and maroon.

$\mathrm{x} / 2 \mathrm{oz}$. $10 \mathrm{c}$

Carnation, Double Mixed. Large, showy, double flowers of various colors..... $1 / 2 \mathrm{oz} .20 \mathrm{c}$. Carnation, Large Double. Scarlet $1 / 2$ oz. 20c. White Swan. Pure white, fringed. . $1 / 2$ oz. 20c.

\section{PERENNIAL POPPIES}

Orientale. One of the most striking and showy of the garden perennials; fowers large brilliant crimson with a black blotch on each petal......

Iceland. Brilliant colors. Blooms first year from seed ...................

\section{Primula-Chinese Primrose}

ing beautiful and brilliantly colored flowers. For brilliant effect and continuous blooming in the flower garden the Phlox cannot be surpassed. Excellent for masses of separate colors or for bouquets. Height 1 foot.

Alba Pura. Pure White............. . 05

Alba Occulata. Dark Purple, white eye.... . . 05

Brilliant. Bright scarlet.............. 05

Finest Mixed. Best large-flowered varieties.

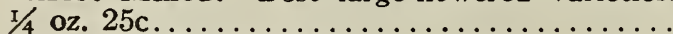

Finest Mixed Dwarf. $\quad \ldots \ldots \ldots \ldots \ldots \ldots \ldots$

Decussata (Perennial). Finest mixed......

PORTULACA. The plants are of low growth and spreading habit. The flowers of the double varieties are like small roses, and make a particularly brilliant show. Sow seed in the open ground as soon as the weather is warm, or in a hotbed earlier. The plants can be transplanted when in full flower. Annual.

Finest Double Mixed......... $\frac{1}{8}$ oz. 50c.

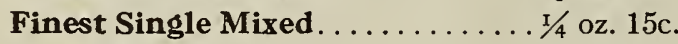

Single Rose.

Single Scarlet...................

Single White..................

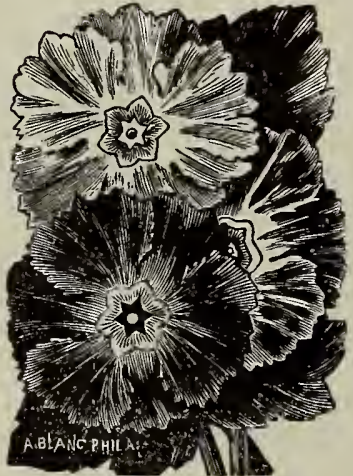

PRIMULA
PRIMULA (Chinese Primrose). A beautiful flowering plant for winter decoration in the home or conservatory. Sow the seed in well-drained shallow pans, from April to the last of July, to insure flowering the following winter. Use finely sifted leaf mold, loam and sand in equal parts.

Per Pkt.

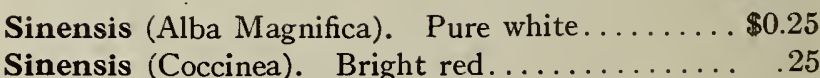

Sinensis. Double white............... . 50

Sinensis. Double fringed. Choicest mixed..... .50 Sinensis Fimbriata. Fringed varieties. Choice mixed...................... .25 
RICINUS (Castor Oil Bean). A half-hardy annual, growing from 6 to 15 feet high and bearing large, green, deep purple and brown leaves, and bright orange and scarlet flowers. Of the easiest culture. Fine for lawns, massing or center plants for beds.

Borboniensis. Green foliage; 15 feet..... Oz. 10c. $\$ 0.05$

Cambodgensis. Dark maroon; stems black; 6 to 8

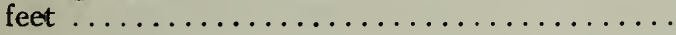

Gibsoni. Deep red foliage; 5 feet....... Oz. 10c.

Sanguineus. Red stems and seeds; 8 feet. . . . . .

Philippinensis. A variety from the Philippines; gigantic purple foliage; 10 feet....... Oz. 15c.

Zanzibarensis Mixed. A very large-leaved variety, light and dark green and bronze, foliage; 10 to 12 feet .............. $15 \mathrm{c}$. Mixed Varieties ............... 10z.

RHODANTHE. Fine for garden. Comes into flower early and continues a long time. One of the best everlastings for bouquets.

Fine Single Mixed ...............

ROSE CAMPION. Fine scarlet flowers; 2 feet. Hardy perennial..................

RUDBEGKIA (Cone-Flower). Robust-growing plants, very popular for border decoration.

Bicolor Superba. Bright yellow with black purple center; 3 feet. Annual............

SALVIA. Sow seed early indoors or in a frame in time to get good plants to set out of doors the latter part of May. Bloom from July to frost. Set plants 1 foot apart. Half-hardy annual.

Bonfire. Very compact, with long, erect spikes of brilliant scarlet flowers. The finest Salvia for bedding. 2 feet......... $\frac{2}{8}$ oz. 50c.

Splendens. Bright scarlet flower-spikes; $2 \mathrm{I} / 2$ feet................. $\frac{2}{8}$ oz. 25c.

Zurich. The earliest blooming variety; the plants are dwarf and compact, producing brilliant scarlet flowers. 1 foot........ $\frac{1}{8}$ oz. $75 \mathrm{c}$.

Patens. Bright blue, extra large flowers. Height $11 / 2$ to 2 feet. . . . . . . . . . . . . .

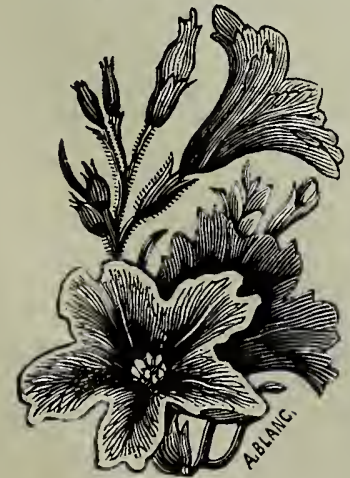

SALPIGLOSSIS. V e $\mathrm{r}$ y showy bedding or border plants with richly-colored flowers, which are purple, scarlet, crimson, yellow, buff, blue or almost black, beautifully marbled and pencilled. Hardy annual, 2 feet.

SALPIGLOSSIS

Grandiflora. Special mixture....... $\frac{1}{8}$ oz. 25 c. $\$ 0.10$ Emperor. Finest Mixed. Very large flowers. $\frac{1}{8}$ oz. $25 \mathrm{c} . \ldots \ldots \ldots \ldots \ldots \ldots \ldots \ldots \ldots \ldots \ldots . .10$

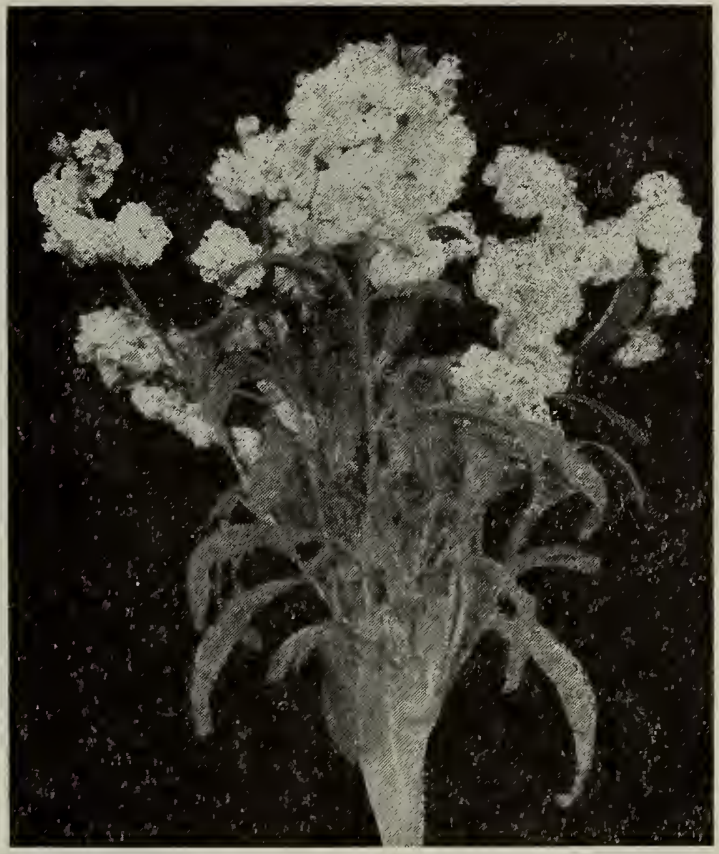

TEN WEEKS STOCKS

STOCKS. Hardy annuals, 2 feet high, with spikes densely covered with beautiful double flowers of almost every desirable tint. Seeds may be sown in the open ground, hotbed or cold frame, but transplanting should be done when the plants are just out of the seed leaf. Make the soil deep and rich, and set the plants a foot apart.

\section{LARGE-FLOWERING TEN WEEKS}

The best variety for bedding out for summer blooming, producing a large percentage of double flowers.

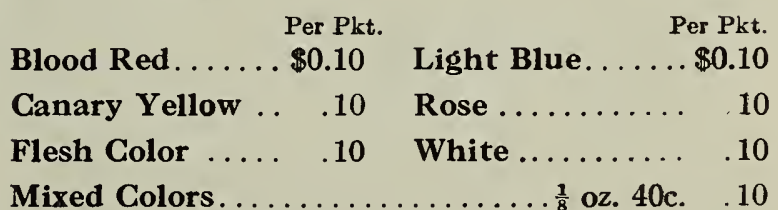

Dresden Perpetual. (Cut-and-Come-Again or Princess Alice). Pure white. Plants of robust growth and branching habit. Fine for cutting.

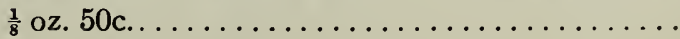

EARLY, LARGE-FLOWERING WINTER STOCKS

Beauty of Nice. Strong spikes, with large flowers of a delicate flesh pink ......... \$0.10

Queen Alexandra. Soft rosy lilac, similar to

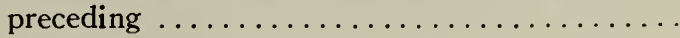




\section{SWEET PEAS}

The popularity of Sieet Peas is demonstrated by the many and beautiful varieties that are introduced each year. Our list includes all the best up-to-date varieties.

Sow as early as the ground can be prepared in a deep, rich moist soil, in drills 6 inches deep, covering about 2 inches deep. As the vines grow, fill up the trenches with soil and thin out to about 4 or 5 inches apart. A popular plan at the present time is to sow in double rows with a trellis or a row of brush between.

\section{SPENCER VARIETIES}

The Spencers have very large waved flowers which are produced abundantly on long, strong stems, and are most desirable for cutting.

America Spencer. Red flakes on white ground. Pkt. 5c., oz. 20c., $1 / 4$ lb. 65 c.

Apple Blossom Spencer. Standard bright rose, wings primrose with a flush of rose tint. Pkt. 5c., oz. 20c., $\mathrm{I} / 4 \mathrm{lb}$. $65 \mathrm{c}$.

Asta Ohn. The best lavender spencer, very large and wary. Pkt. 5̃c., oz. 20 c., $1 / 4$ lb. 65 c.

Aurora Spencer. White, with stripes and flakes of orange-pink. Pkt. 5c., oz. 20c., I/4 lb. 65 c.

Captain of the Blues Spencer. Deep blue. Pkt. 5c., oz. 20c., $1 / 4$ lb. $65 \mathrm{c}$.

Countess Spencer. The original giant-flowered Spencer. Clear Pink. Pkt. 5̃c., oz. 20c., I/4 lb. $65 \mathrm{c}$.

Dainty Spencer. White with rose-

pink edges. Pkt. כ̄c., oz. 20c., $1 / 4 \mathrm{lb} .65 \mathrm{c}$.

Dobbie's Cream. The finest primrose-yellow. Pkt. 10c., oz. 40 c., I $/ 4$ lb. $\$ 1.30$.

Edith Taylor. Salmon rose. Pkt. 5c., oz. 25c., I/4 Ib. $75 \mathrm{c}$.

Ethel Roosevelt. Primrose striped light pink. Pkt. 5c., oz. 20c., $1 / 4 \mathrm{lb} .65 \mathrm{c}$.

Etta Dyke. Large, wavy, pure white. Pkt. כ̌c., oz. $25 \mathrm{c}, \mathrm{1} / 4 \mathrm{lb} .75 \mathrm{c}$.

Evelyn Hemus. Buff and primrose with clear rose margin. Pkt. 5c., oz. 20c., 1/4 lb. $65 \mathrm{c}$.

Fiery Cross. A scorching fire-red or rich orange-scarlet. The beautifully waved and fluted flowers are borne freely in threes and fours on long, stout stems. Pkt. 15c., oz. $\$ 1.00$.

Florence Nightingale. Large, bluish lavender. Pkt. 5c., oz. 20c., 1/4 lb. 65 c.

Geo. Herbert. A large Spencer rose-crimson. Pkt. う̌c., oz. 20 c., $1 / 4$ lb. 65 c.

Helen Lewis. Orange-pink with bright orange standard. Pkt. 5c., oz. 20c., 1/4 lb. 65c.

King Edward. The best pure red Spencer, very large. Pkt. 5c., oz. 20c., 1/4 lb. 60c.

King Manoel. Largest deep, maroon. Pkt. 10c., oz. 40 c., I $/ 4$ lb. $\$ 1.50$.

King White. The grandest of all White Sweet Peas. Pkt. 10c., oz. 40c., 1/4 lb. $\$ 1.25$.

Margaret Atlee. A rosy salmon-pink on a creamy buff ground; a rich, soft color, and extremely attractive. Pkt., 10c. oz. 35c., 1/4 lb. \$1.25.

Marie Corelli. Rose-Carmine. Pkt. ǰc., oz. 10c., I/4 lb. 65 c.

Mary Garden. Bright cream rose-pink; inclined to double. Pkt. 5c., oz. 20c., 1/4 lb. 65c.

Mrs. Hugh Dickson. Buff, apricot and rose. Pkt. ǰc., oz. 20 c., I $1 / 4$ lb. 6 כ̌c.

Mrs. Routzahn. Straw-color tinted with blush pink. Pkt. 5c., oz. 20c., 1/4 lb. 65c.

Margaret Madison. A perfect Spencer of delicate azure blue. Pkt. 10c., oz. 35.c., 1/4 lb. $\$ 1.25$.

New Miriam Beaver. A bright apricot pink on a primrose ground. Pkt. 10c., oz. 50c., $\frac{1}{4}$ lb. $\$ 1.50$.
Othello Spencer. Deep, rich maroon. Pkt. う̌c., oz. 20 c., $1 / 4$ lb. 65 c.

Primrose Spencer. Clear primrose-color. Pkt. 5c., oz. 20c., $1 / 4$ lb. $65 \mathrm{c}$.

Thomas Stevenson. Bright orange scarlet. Plit. 10c., oz. 30c., I/4 lb. $\$ 1.00$.

White Spencer. Pure white. Pkt. 5c., oz. 20c., I/4 lb. $65 \mathrm{c}$.

Superb Spencer Mixed. A splendid mixture of true Spencer types only. Pkt. 5c., oz. $15 \mathrm{c}$., 1/4 lb. $50 \mathrm{c}$.

\section{Grandiflora-(Large Flowered) and Unwin Types}

These have large handsome flowers, but the petals are not waved like the Spencer varieties.

Price of any of the following varieties: Pkt. 5c., oz. 10c., $1 / 4$ lb. 20c., $1 / 2$ lb. 35 c., lb. 60 c.

One quarter of a pound of seed will sow fifty feet.

America. Bright red striped on white.

Aurora. Orange rose striped on white.

Apple Blossom. Shaded pink and white.

Black Knight. Deep Maroon.

Blanche Burpee. Large, pure white.

Blanche Ferry. Pink and white.

Coccinea. Cherry-red.

Countess of Radnor. Pale lavender.

Dainty. White with pink edge.

Dorothy Eckford. Fine pure white, large.

Duke of Westminster. Purple, tinted with violet.

Emily Henderson. White, large size.

Flora Norton. Bright blue with tint of purple.

Hon. Mrs. E. Kenyon. Primrose-yellow; a fine, large flower.

Hon. F. Bouverie. Standard and wings both deep pink shading to light pink.

Janet Scott. Deep bright pink.

Katherine Tracy. Brilliant Pink, large flowering.

King Edward VII. Crimson scarlet, very large.

Lady Grisel Hamilton. A pale lavender.

Lord Nelson. Deeper and richer shade than Navy Blue.

Lovely. Soft shell pink; large flowering.

Miss Wilmott. Orange pink; very large flowering.

Mrs Walter Wright. Deep mauve. 


\section{SWEET PEAS-Continued}

Navy Blue. Standard indigo and violet, wings violet and bright blue.

Prima Donna. Soft clear pink.

Prince of Wales. Rose Crimson.

Queen Alexandra. Flowers large. Brilliant scarlet.

"A., S. \& L." SPECIAL MIXTURE. This mixture is made up by ourselves from the best named varieties and cannot fail to give satisfaction. Pkt. 5c., oz. $10 \mathrm{c} ., 1 / 4 \mathrm{lb} .20 \mathrm{c} ., 1 / 2 \mathrm{lb} .35 \mathrm{c} ., 1 \mathrm{lb} .60 \mathrm{c}$.

EARLY FLOWERING OR CHRISTMAS VARIETIES

Earliest of All. Pink and White. Pkt. 5c., oz. 15c., $1 / 4 \mathrm{lb} .50 \mathrm{c}$

Mont Blanc. Pure white. Pkt 5c., oz. 15c., 1/4 lb. 50c.

Mrs. Chas. H. Totty. Lavender. Pkt. 5c., oz. 15c., $1 / 4 \mathrm{lb} .50$.

Mrs. F. J. Dalansky. Pink. Pkt. 5c., oz. 15c., 1/4 lb. 50c.

For 35c. we will mail ten 5 cent pkts. Sweet Peas.

For 70c. we will mail ten 10 cent pkts. Sweet Peas.

SCHIZANTHUS. Hardy annuals, growing $1 \frac{1}{2}$ to 2 feet high, and covered with bright, showy, butterfly-like blossoms. Mixed. Large flowering. $\$ 0.05$

SENSITIVE PLANT. Curious and interesting annuals, with pinkish-white flowers; the leaves close and droop when touched or shaken; $11 / 2$

feet ........................................ bright-green, glossy leaves, much esteemed for its long, delicate sprays of foliage. Largely used for decorating. It requires strings or wires

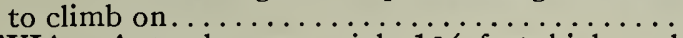

STEVIA. A tender perennial, $11 / 2$ feet high and bearing clusters of small, white, fragrant blossoms. Suitable for summer or winter blooming.

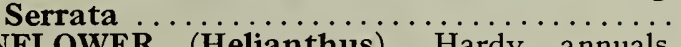

SUNFLOWER (Helianthus). Hardy annuals, growing from 3 to 6 feet high. Of the easiest culture and suitable for a stately row or background. Plant in light or sandy soil.

Californicus fi. pl. Splendid variety, with magnificent heads of double orange flowers. 5 feet. Oz. 20c.......................... Miniature. Small, single, rich yellow flowers, with black center. 4 feet........... Oz. 20c.

SUTTON'S RED. Single large red flowers, shading to yellow at tips of petals. $6 \mathrm{ft} . \ldots \ldots \ldots \ldots \ldots$. Mammoth Russian. Large yellow. Oz. 5c.

SWEET ROCKET. Fragrant, hardy perennial, growing freely in ordinary soils.

Mixed. Purple and white...............

SWEET SULTAN. Large, sweet-scented flowers on long stems, fine for cutting. 2 feet.

White

Pink, white Genter .....................

Dark Blue $\ldots \ldots \ldots \ldots \ldots \ldots \ldots \ldots \ldots$.

Light Blue $\ldots \ldots \ldots \ldots \ldots \ldots \ldots \ldots \ldots \ldots \ldots \ldots \ldots \ldots \ldots$

Finest Mixed

SWEET WILLIAM. An old-fashioned plant, producing large heads of beautifully colored, sweet-scented flowers. It is hardy and easily grown. Hardy perennial. $1 \frac{1}{2}$ feet.

\section{SWEET WILLIAM - Continued}

Per Pkt.

Holborn Glory. Large flowers of the most beautiful shades ................1/4 oz. 25 c. $\$ 0.05$ Auricula-Flowered. Single varieties, mixed.

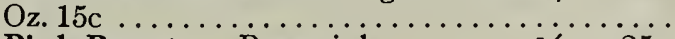
Pink Beauty. Rose pink......... 1/4 oz. 25c. Double Varieties. Mixed......... I/4 oz. 25c.

TASSEL FLOWER. An annual of easy culture, with tassel-shaped flowers, blooming profusely from July to October. 18 inches.............

THUNBERGIA. For house culture, baskets and vases, there are few plants superior to the Thunbergia, as they are beautiful, rapid-growing annual climbers, with pretty flowers (white, buff or orange, with dark eyes), borne in profusion. Mixed colors...................

VERBENA. A well-known annual for beds, and borders. Seed sown in March will bloom in June and continue until frost. Plants raised from seed are more vigorous and produce more flowers than those grown from cuttings.

Mammoth White .............. $1 / 8$ oz. 15c

Mammoth Pink .................

Mammoth Scarlet ............... $1 / 8$ oz. 15c

Mammoth Purple ............. $1 / 8$ oz. 15c

“A., S. \& L." Mammoth Mixed $1 / 4 \mathrm{oz}$. 30c

Fine Mixed ................. $1 / 8$ oz. 10c

Lemon Scented. Lemon scented foliage.....

VIOLET, Sweet-scented (Viola odorata). Fragrant, spring-blooming plants; hardy perennial. Single Mixed. Blue and white...

VIRGINIA STOCK. Sweet-scented hardy annual. Mixed $. . . \ldots \ldots \ldots \ldots \ldots \ldots \ldots \ldots . . . \ldots \ldots$.

WALLFLOWER. An old favorite garden flower. The large, massive spikes of the Wallflower are very conspicuous in beds and borders and are very useful in making bouquets. Height about $11 / 2$ feet.

Single Mixed. Perennial............... Double Mixed. Perennial ...................

Single Annual Mixed: Annual..............

WILD GUGUMBER (Echinocystis Lobata). This is a useful climber where a rapid and vigorous growth of vine is desired. The vine is thickly covered with white, fragrant flowers. Hardy annual. Oz. $15 \mathrm{c}$., $1 / 2 \mathrm{oz}$. 10c.

ZEA JAPONICA (Striped Japanese Maize). Very ornamental, variegated foliage...........

ZINNIA. A hardy annual, growing from 1 to 2 feet high. One of the most brilliant and showy plants. They flower early in the summer and keep on blooming until frost. Sow in boxes early and transplant.

\section{GIANT FLOWERING DOUBLE}

Giant Flesh- Per Pkt. Giant Golden- Per Pkt. color ....... $\$ 0.10$ yellow ......\$0.10

Giant Violet..... .10 Giant Scarlet ... $\quad .10$

Giant Crimson .10 Giant White .... $\quad .10$

Giant Mixed. All colors.......... 1/4 oz. 40c. .10

Haageana, dwarf, double golden........... . .05

Tall, Double Mixed.................... . .05

Dwarf, Double Mixed................ .05

WILD GARDEN FLOWER SEEDS. A mixture of easily grown varieties of Flower Seeds for Sowing broadcast, require very little care and produce a continual display of bloom throughout the season, and furnish an abundance of flowers for cutting. They are useful for sowing along fences and on unsightly bare spots of ground. Pkt. 5c., oz. 10c., $1 / 2$ lb. 30c.
10

10

10

05

10

10

05




\section{Summer=Flowering Bulbs}

BEGONIAS (Tuberous-Rooted). Unequalled for summer bedding, making a dazzling show throughout the entire season.

Single. Orange, rose, scarlet, white, yellow, pink, crimson, salmon. 5c. each, 60c. per doz., $\$ 3.75$ per 100.

A11 Colors Mixed. 5c. each, 60c. per doz., $\$ 3.75$ per 100.

Double. Red; rose, yellow, white, orange, salmon. 10c. each, $\$ 1.00$ per doz., $\$ 7.00$ per 100 .

Parcel Post prepaid.

CALADIUM ESCULENTUM (Elephant's Ear). Very effective and easily grown foliage plants for the lawn or border. Bulbs 6 to 8 inches in circumference. 10c. each, $\$ 1.00$ per doz., by Parcel Post, doz. $\$ 1.10$.

DAHLIAS. Popular summer and autumn-flowering plants. Named varieties, $15 \mathrm{c}$. each, $\$ 1.25$ doz., by Parcel Post doz. $\$ 1.35$

\section{GLADIOLUS}

Attractive summer-flowering bulbs. They will grow in any good garden soil. Single and dozen prices include postage.

America. Soft lavender-pink, very beautiful. 5c. each, 30c. doz., $\$ 1.50$ per $100, \$ 1.75$ per 100 by Parcel Post.

Augusta. Pure white with blue anthers, good for early forcing. 5c. each, 40c. doz., $\$ 2.50$ per 100 , $\$ 2.75$ per 100 by Parcel Post.

Baron Hulot. Rich, deep, indigo blue. 6c. each, 45c. doz., $\$ 2.50$ per $100, \$ 2.75$ per 100 by Parcel Post.

Brenchleyensis. Bright scarlet. 5c. each, 25c. doz., $\$ 1.50$ per 100 , $\$ 1.75$ per 100 by Parcel Post.

Empress of India. Deep velvety maroon. 6c. each, 60c. doz., $\$ 4.50$ per $100, \$ 4.75$ per 100 by Parcel Post.

Europe. Beautiful white with a faint tinge of lilac in the throat. 10c. each, $\$ 1.00$ doz., $\$ 7.00$ per 100 , $\$ 7.25$ per 100 by Parcel Post.

Glory of Holland. Large, pure white, tinted rose. 6c. each, 50c. per doz., $\$ 3.50$ per $100, \$ 3.75$ per 100 by Parcel Post.

Golden West. Orange-red overlaid with gold, spotted red on lower petals. 6c. each, 60c. doz., $\$ 4.50$ per $100, \$ 4.75$ per 100 by Parcel Post.

Halley. A large flower of salmon-pink tinged rose. 5c. each, 30c. doz., $\$ 1.50$ per $100, \$ 1.75$ per 100 by Parcel Post.

Hollandia. Pale buff color with red stripes. 4c. each, 30c. doz., $\$ 1.75$ per $100, \$ 2.00$ per 100 by Parcel Post.

Kunderdi Glory. Creamy pink with carmine stripe. 10c. each, $\$ 1.00$ doz., $\$ 7.00$ per $100, \$ 7.25$ per 100 by Parcel Post.

Liebesfeuer. Beautiful red. 20c. each, $\$ 1.75$ doz., $\$ 12.00$ per 100 .

Lily Lehman. Large, pure white flower with frilled edge. 5c. each, 45 c. doz., $\$ 3.00$ per $100, \$ 3.25$ per 100 by Parcel Post.
Loveliness. Cream, with apricot and primrose throat. 8 c. each, 75c. doz., $\$ 5.00$ per 100 , $\$ 5.25$ per 100 by Parcel Post.

Mrs. Francis King. Beautiful vermilion scarlet. $4 \mathrm{c}$ each, 30c. doz., $\$ 1.75$ per $100, \$ 2.00$ per 100 by Parcel Post.

Mrs. Frank Pendleton, Jr. Bright salmon-pink, very large flowers. 20c. each, $\$ 1.75$ doz., $\$ 12.00$ per 100.

Niagara. Large creamy white flowers, splashed with carmine. 10c. each, 85c. doz., $\$ 6.00$ per $100, \$ 6.25$ per 100 by Parcel Post.

Orion. Blush-yellow, brown-red. 5c. each, 30c. doz., $\$ 1.50$ per 100 , $\$ 1.75$ per 100 by Parcel Post.

Panama. A deeper pink than America, long, strong spike with large open flowers. 10c. each, $85 \mathrm{c}$. doz., $\$ 6.00$ per $100, \$ 6.25$ per 100 by Parcel Post.

Peace. Flowers large and of fine form; color, pure white, feathered with pale lilac. 10c. each, 85c. doz., $\$ 6.00$ per $100, \$ 6.25$ per 100 by Parcel Post.

Princeps. Large flowers of a rich, glowing crimson with white on lower petals. 10c. each, 85c. doz., $\$ 6.00$ per $100, \$ 6.25$ per 100 by Parcel Post.

Schwaben. Clear sulphur-yellow with small brown spot in the throat. 10c. each, $\$ 1.00$ doz., $\$ 7.00$ per 100.

War. Deep blood-red, shaded crimson-black. $15 \mathrm{c}$. each, $\$ 1.50$ doz., $\$ 9.00$ per 100 .

Willy Wigman. Delicate rose, tinted cream, with large carmine red blotch. 5c. each, 45c. doz., $\$ 3.00$ per $100, \$ 3.25$ per 100 by Parcel Post.

Pink and Rose Shades. Mixed. 3c. each, 20c. doz., $\$ 1.75$ per $100, \$ 2.00$ per 100 by Parcel Post.

Scarlet and Crimson Shades. Mixed. 3c. each, 20c. doz., $\$ 1.75$ per $100, \$ 2.00$ per 100 by Parcel Post.

White and Light Shades. Extra mixed. 3c. each, 20c. doz., $\$ 1.75$ per $100, \$ 2.00$ per 100 by Parcel Post.

Fine Mixed. 2c. each, 15c. doz., $\$ 1.50$ per 100 , $\$ 1.75$ per 100 by Parcel Post.

GLOXINIA. Showy, free-flowering plants; indoor culture. We have these in the following colors, viz.: Brilliant scarlet, violet, white, crimson, spotted, scarlet with border, blue with white border. $10 \mathrm{c}$. each, $\$ 1.00$ per doz. Postage Prepaid.

MADEIRA VINE. A popular climbing plant. 5c. each, 40c. per doz., 50c. per doz. by Parcel Post.

TUBEROSE. If planted in pots in March, and transplanted to the open ground when the weather becomes warm, flowers can be had much earlier.

Excelsior Pearl. Large, double, white flowers. 5c. each, 30c. per doz., 40c. per doz. by Parcel Post.

CANNAS. Fine ornamental plants, blooming from July until frost. Red-flowering, green-foliage Cannas; pink-flowering, orange-flowered, white and cream shades; red gold-edged, yellow shades; bronze-leaved, red-flowered; orchid-flowering. All the above varieties, 15c., each, per doz. $\$ 1.50$. 


\section{PLANT DEPARTMENT}

PLANTS BY EXPRESS. We use great care in the packing of plants to be sent by express, but cannot be responsible for delays or conditions when received by the purchaser. No plants sent $\mathrm{C}$. $\mathbf{O}$. $D$.

\section{Vegetable Plants}

\section{ASPARAGUS ROOTS}

We offer strong two-year old roots of the following varieties-Mammoth White, Palmetto and Conover's Colossal

25 roots, by express, at purchaser's expense.... . \$0.35

25 " by mail.................. .40

50 " by express, at purchaser's expense.... .50

50 " by mail .................... .65

100 " by express, at purchaser's expense.... 1.00

100 " by mail................... 1.25

1000 " by freight or express, at purchaser's

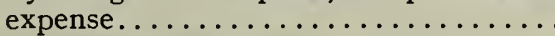

7.00

\section{GABBAGE PLANTS}

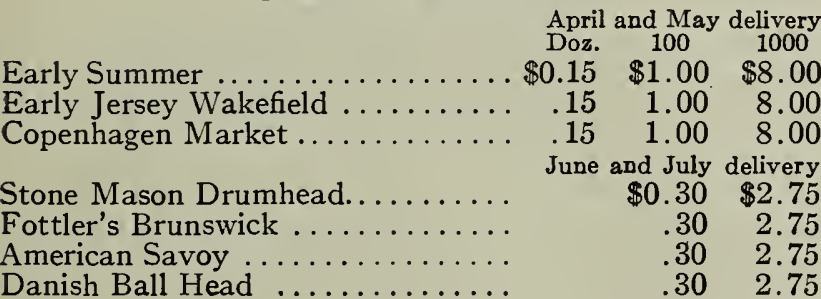

\section{CAULIFLOWER PLANTS}

May and June delivery

$\$ 0.20 \$ 1.25$

Snowball

$.20 \quad 1.25$

CELERY PLANTS

White Plume $\ldots \ldots \ldots \ldots \ldots \ldots \ldots \ldots . \$ 0.75 \quad \$ 6.00$

Golden Self-Blanching ................ $\quad .75 \quad 6.00$

Boston Market ....................... .75 6.00

LETTUCE

Boston Curled $\ldots \ldots \ldots \ldots \ldots \ldots \ldots \ldots \$ \$ \ldots .20 \quad \begin{array}{ll}\text { Doz. } & 100 \\ \$ 1.00 & 1.00\end{array}$

Black-seeded Tennisball ............... $\quad .20 \quad 1.00$

\section{PEPPER}

Large Bell ....................... \$0.20

Squash $\ldots \ldots \ldots \ldots \ldots \ldots \ldots \ldots \ldots \ldots . .20$

$\$ 1.25$

1.25

\section{RHUBARB ROOTS}

Each, $\$ 0.15 \$ 1.50 \quad \$ 10.00$

\section{TOMATO PLANTS}

\section{Pot Grown}

Earliana, Early Detroit, "John Baer" $\$ 0.50$

\section{Box Grown.}

"John Baer" Earliana, Chalk's Jewel, Early Detroit, Beauty Dwarf Stone, Bonny Best, Yellow Plum, Red Cherry....................... . 30

\section{Flowering and Foliage Plants for Summer Bedding}

\section{Bedding plants shipped by express only}

\begin{tabular}{|c|c|c|c|c|c|}
\hline & & $\begin{array}{r}\text { Doz. } \\
\$ 1.00\end{array}$ & & $\begin{array}{l}\text { Each } \\
\$ 0.20\end{array}$ & $\begin{array}{r}\text { Doz. } \\
\$ 1.75\end{array}$ \\
\hline $\begin{array}{l}\text { Ageratum. Dwarf, blue } \\
\text { Alternanthera. Dwarf . }\end{array}$ & & $\$ 1.00$ & $\begin{array}{l}\text { Geraniums. Assorted varieties, } 4 \text { in. Pots. } \\
\text { Geraniums. Assorted varieties, } 3 \text { in. Pots. }\end{array}$ & .10 & \\
\hline Alyssum. White ........ & .08 & .60 & Geraniums. Ivy-Leaved sorts, 4 in. Pots. . & .15 & \\
\hline gonia. Tuberous-rooted & .25 & 2.00 & Rose-scented, 4 in pots...... & .15 & \\
\hline dula. Deep yellow & .10 & & Heliotrope. Dark and light... & & \\
\hline nnas. Dwarf flow & & 1. & Hollyhock, Double. Assorted. & .15 & \\
\hline robusta. & .1 & 1.8 & & & \\
\hline ea candidissin & .1 & & - In variety & .10 & \\
\hline gy & & & erbe & .20 & 1.75 \\
\hline Scander & & 1.50 & . $\mathrm{Da}$ & .10 & .75 \\
\hline Fine varieties. Per $100 \$ 5.00$ & .08 & & ld. $F_{r}$ & .15 & 1.50 \\
\hline Bellis $\mathrm{F}$ & & & Doub & & \\
\hline in & .75 & 6.0 & Bingle. Ass & .10 & 1.00 \\
\hline kets & & & astor-oil Bec & .10 & 1.0 \\
\hline ew. Double & .10 & $1 .($ & ndens. $\mathrm{Be}$ & & \\
\hline rfew. Golden & & & ia, Trailing. & 10 & 1.00 \\
\hline Var & 20 & & & .25 & 2.50 \\
\hline
\end{tabular}

\section{FLOWER SEEDLINGS}

\section{Shipped by express only}

Per Doz.

$\$ 0.15$

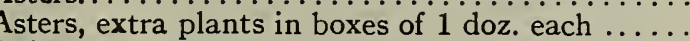

.25

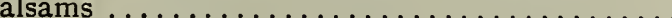

.15

Calendula

Coreopsis

.15

.15

.20

Gaillardia

Mignonette

Nasturtium.

Nasturtium.

Dwarf; assorted

Tall; assorted
Per Doz.

$\$ 0.30$

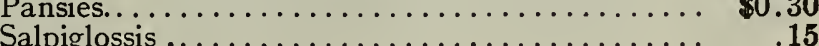

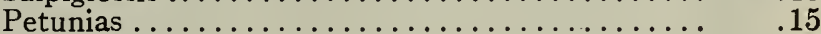

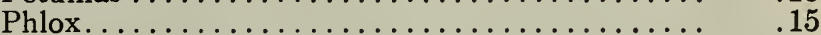

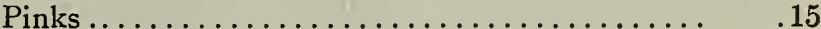

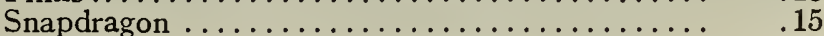

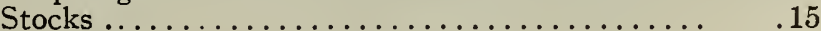

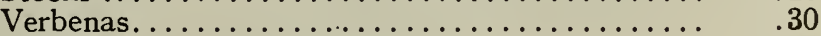

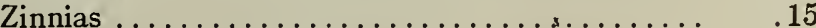




\section{BUCKEYE INCUBATORS}

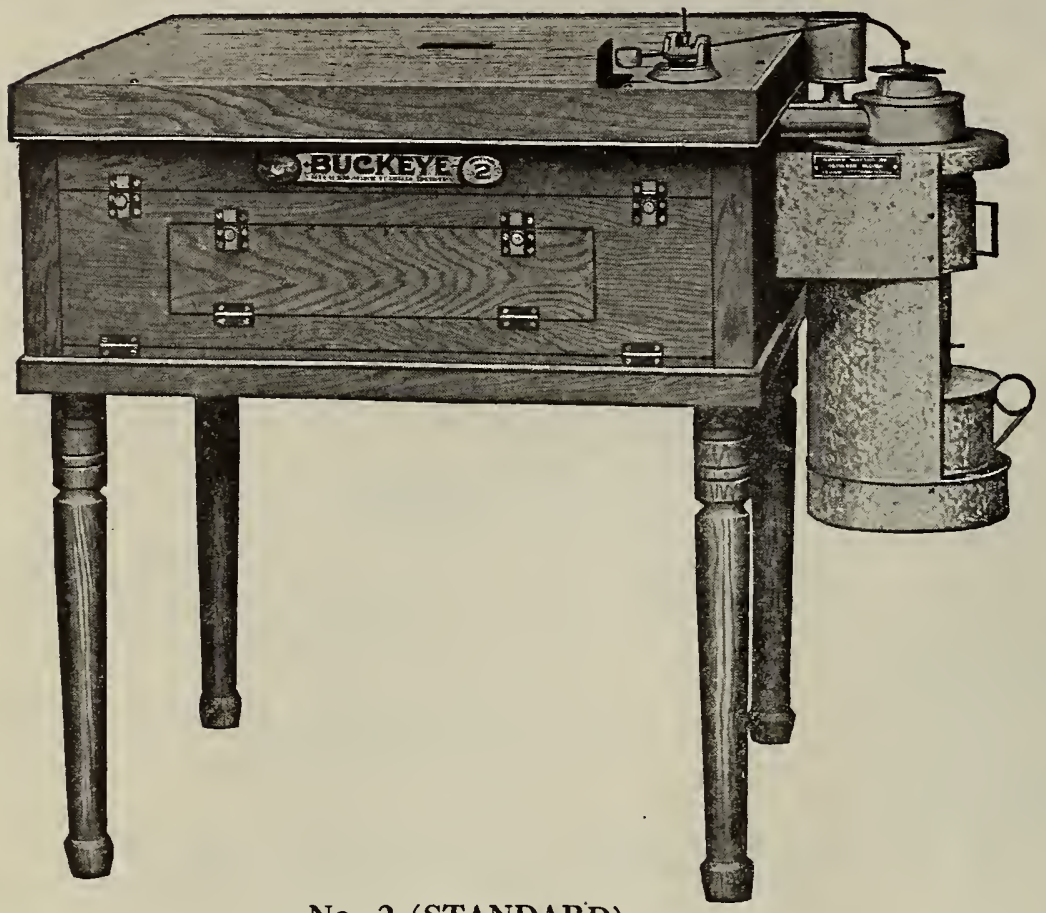

\section{THE "STANDARD” HOT WATER} HATCHING DEVICE

No. 2 (STANDARD)

Buckeye incubators are equipped with every desirable device that can possibly add to incubator efficiency and they are sold with an absolute guarantee to hatch a chick from every hatchable egg.

Buckeye incubators are so simple that the beginner can operate them just as successfully as the experienced poultryman-that's why they are so uniformly satisfactory.

... PRICES . . .

No. 1, Standard, Capacity 110 Eggs, $\$ 21.00 \quad$ No. 4, Standard, Capacity 350 Eggs, $\quad \$ 38.00$ No. 2, Standard, Capacity 175 Eggs, $\quad 26.00 \quad$ No. 5, Standard, Capacity 600 Eggs, $\quad 60.00$ No. 3, Standard, Capacity 250 Eggs, $\quad 33.00$

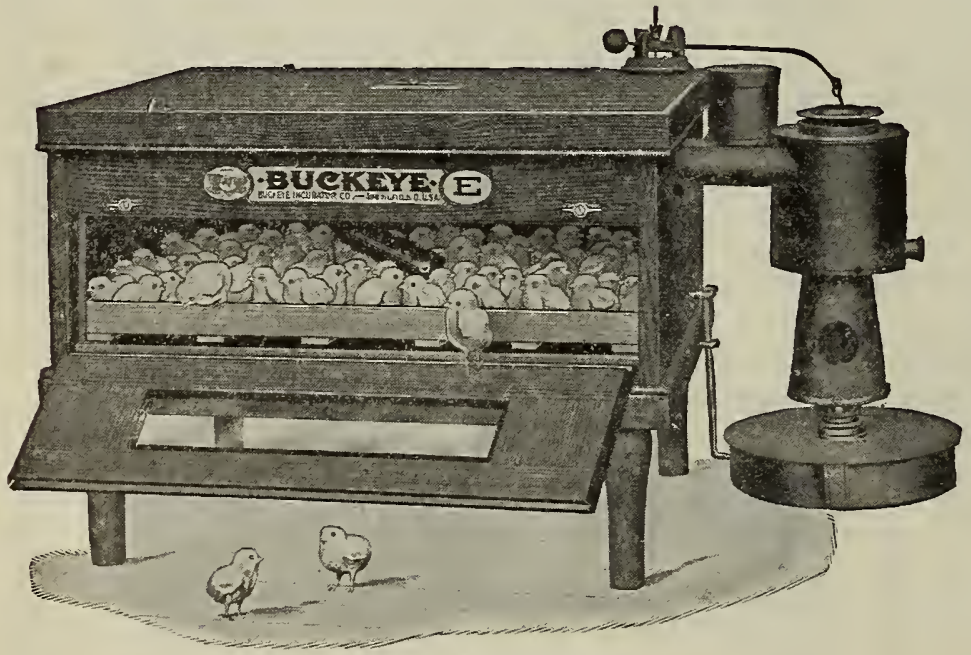

\section{Style E}

\section{A Remarkable Incubator}

\section{At a Remarkable Price}

With All the Desirable Buckeye Features

No. 14, Style E, Capacity, 60 Eggs,

$\$ 8.50$

No. 15, Style E, Capacity, 60 Eggs,

11.00

No. 16, Style E, Capacity, 110 Eggs,

15.00

No. 17, Style E, Capacity, 200 Eggs,

19.50

No. 14 (Style E)

Ask For Illustrated Catalogue of Buckeye Incubators. 


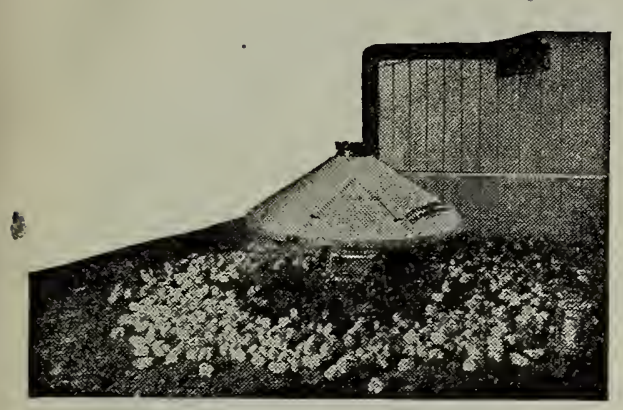

Moving toward or away from the heater, they get the temperature they prefer.
Newtown Giant Colony Brooder

"BUILT FOR LONGTIME SERVICE"

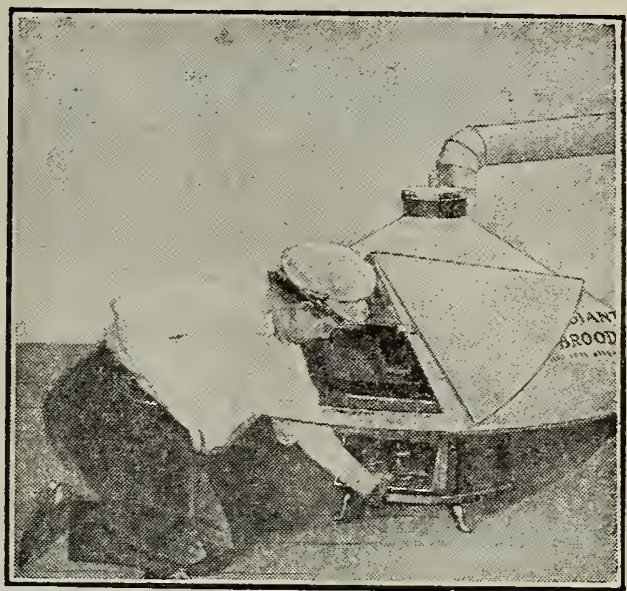

Shaking Grate--sliding door in Deflector raised.

\section{The Great Time, Labor, Fuel and Chick Saver Coal=Burning, Self=Regulating, Simple, Safe and Economical.}

Coal is recognized as the safest fuel to use to guard against the burning of property-the Newtown burns coal.

Every part of the Newtown Heater is cast iron with the exception of its heavy sheet metal casing around the fire bowl, which is a special safety feature. Air circulates between the heavy sheet metal casing and the hot fire bowl, which prevents over-heating of this part, so that there is no danger of the litter or buildings catching fire. The fire bowl is not exposed.

Prices, No 10, $\underset{\text { or less. }}{300 \text { Chicks }} \$ 20.00$; No. 11, $\underset{\text { or less. }}{500 \text { Chicks }} \$ 25.00 ;$ No. $12, \underset{\text { or less. }}{\text { For }} \mathbf{1 2 0 0 \text { Chicks }} \$ \mathbf{3 2 . 5 0}$.

Write for Descriptive Catalogue.
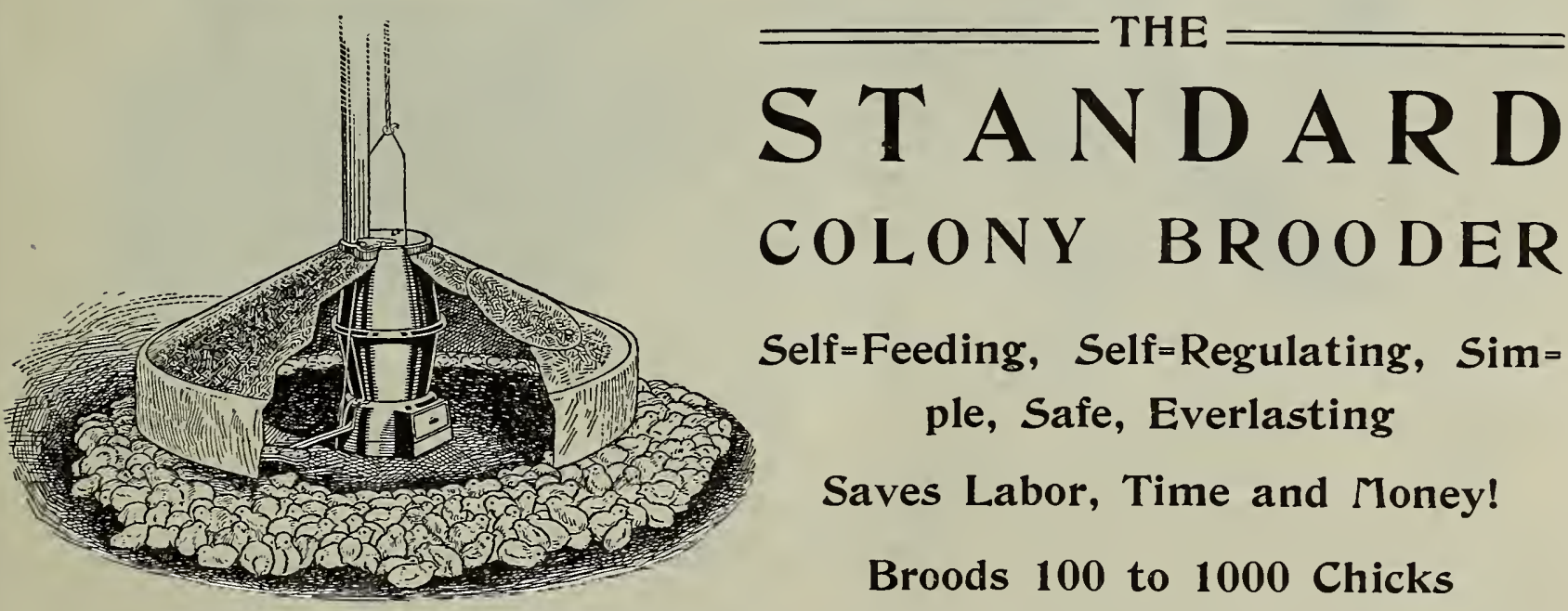

\section{Self=Feeding, Self=Regulating, Sim= ple, Safe, Everlasting}

\section{Saves Labor, Time and Money!}

\section{Broods 100 to 1000 Chicks}

ABSOLUTE COMFORT FOR THE CHICKS. It is a well-established fact that every chick is not entirely comfortable in the same temperature-some require a little more heat, while others require less. Under the conditions provided by the Standard Colony Brooder, every chick can seek the precise temperature that suits it best. If it needs plenty of warmth it moves closer to the stove, and if it requires less heat it moves farther away from the stove. They follow the natural inclinations of nature.

IT IS ECONOMICAL, as it burns but three to six cents' worth of coal in a day. In ordinary cool weather it cannot burn more than three cents' worth of coal, and with the weather below freezing it cannot burn more than six cents' worth in a day. 


\section{THE INTERNATIONAL SANITARY HOVER}

The Sanitary Hover can be used anywhere that there is protection for the chicks from wind and rain. It is not a center heat hover. It is warmest at the outer edge, which causes the chicks to distribute themselves near the curtain and prevents crowding and smothering the chicks.

It is a perfectly ventilated brooding device. It supplies plenty of fresh air for all the chicks, with no drafts. It can be carried around with ease and is ready for use wherever it may be dropped. No carpenter work is required to set it up-no cutting of holes nor building of platforms. All one has to do to set it up is set it down. A simple, safe, convenient, and dependable brooding device.

\section{Price, $\$ 8.50$}

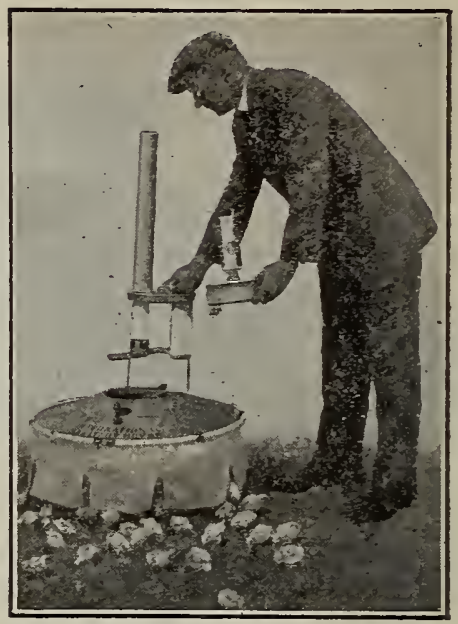

Write for Descriptive Catalogue
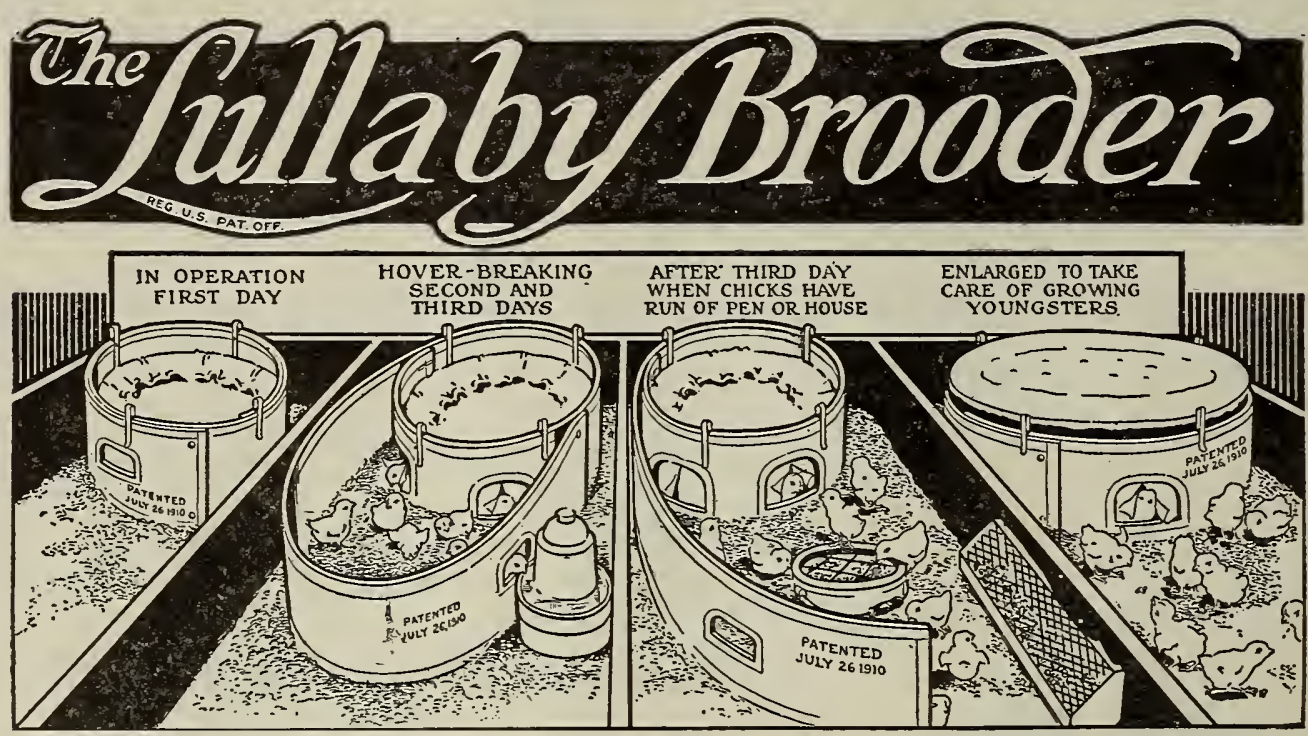

Get away from the old idea that you should keep fifty chickens in a lot. You will make almost, if not quite, as much profit with twenty-five chickens raised in the "Lullaby" way as with fifty raised in the old-fashioned way.

It is not a question of how many chicks you put together in the spring that tells the profit later. It is "How many did you raise out of every Ioo hatched?"

Price, $\$ 1$ each, F. O. B. Portland. (Parcel Post Charge, 1st and 2nd zones 6c., 3rd 8c.)

\section{BUCKEYE FIRELESS BROODERS}

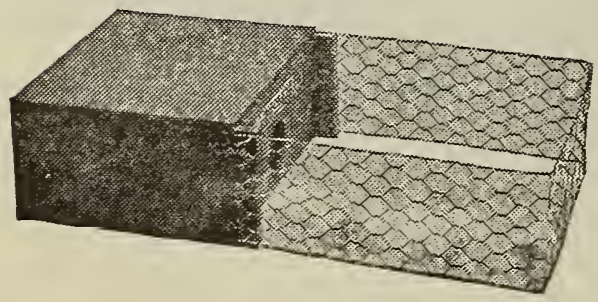

No. 5, Capacity 25 Chicks,

Price, $\$ 1.50$ Size of hover, $12 \mathrm{t} / 2$ inches long by 16 inches wide. Size of yard, 16 inches long by 16 inches wide.

No. 6, Capacity 50 Chicks,

Price, $\$ 2.50$ Size of hover, 20 inches long by 20 inches wide. Size of yard, 17 inches long by 20 inches wide. 
Eyrie

Egg

Shipping

Box

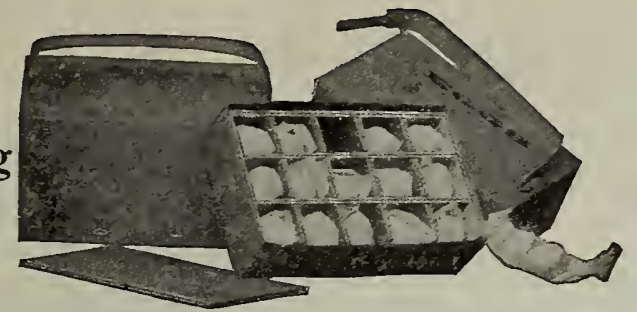

For shipping hatching eggs by express. Made of heavy corrugated cardboard, very strong, compact, light and convenient.

1 Setting, each 15c.; $\$ 1.50$ per doz.

2 Settings, each 20 c.; $\$ 2.00$ per doz.

\section{THE ANDERSON EGG BOX}

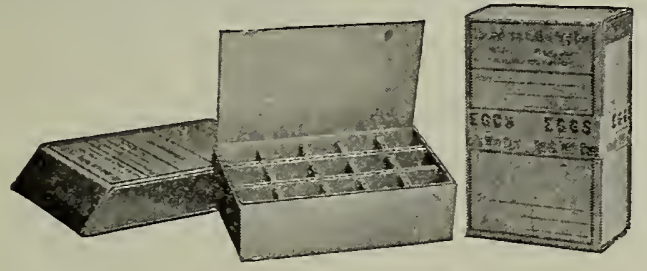

Made of corrugated paper with double faced corrugated paper partitions protecting each individual egg. Folded flat for Shipment.

$\begin{array}{lrrrrr} & \text { Each } & \text { Doz. } & & & \\ 1 \text { Setting } & \mathbf{\$ 0 . 2 0} & \mathbf{\$ 2 . 0 0} & 50 \mathrm{Egg} \text { Size } & \mathbf{\$ 0 . 3 8} & \mathbf{\$ 4 . 0 0} \\ 2 \text { Settings } & .30 & \mathbf{2 . 9 0} & 100 \mathrm{Egg} \text { Size } & \mathbf{. 6 0} & \mathbf{6 . 5 0}\end{array}$

\section{SEFTON LIVE CHICK BOX}

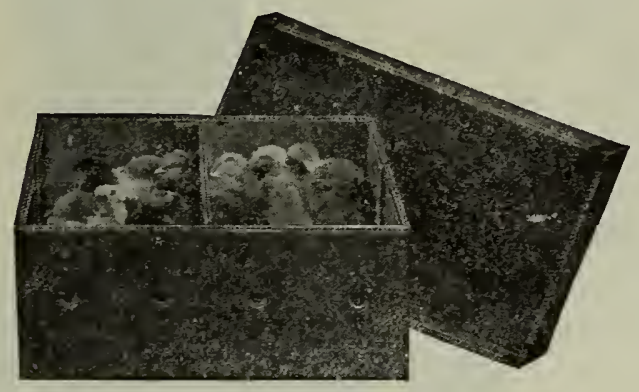

Made from best grade of corrugated paper. For shipment it is folded flat, but can be easily set up and made ready for use.

$\begin{array}{rlrr} & \text { Each } & \text { Doz. } \\ 25 \text { Chicks. } & \text { Size } 12 \times 6 \times 5 & \$ 0.20 & \$ 2.00 \\ 50 \text { Chicks. } & \text { Size } 12 \times 12 \times 5 & . \mathbf{2 5} & \mathbf{2 . 5 0} \\ 100 \text { Chicks. } & \text { Size } 24 \times 12 \times 5 & .38 & \mathbf{4 . 2 5}\end{array}$

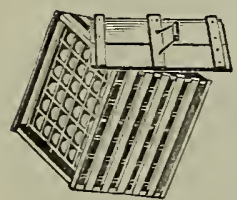

\section{Humpty Dumpty Folding Egg Crate}

A very light, strong and convenient egg crate and carrier.

$\begin{array}{rrr}\text { Size } & \text { Each } & \text { Per Doz. } \\ 3 \text { Doz. } & \$ \mathbf{\$ 0 . 2 5} & \$ 2.75 \\ 6 \text { Doz. } & .30 & \mathbf{3 . 0 0} \\ 9 \text { Doz. } & \mathbf{. 3 5} & \mathbf{3 . 2 5} \\ 12 \text { Doz. } & \mathbf{. 4 0} & \mathbf{3 . 5 0}\end{array}$

\section{“BERKSHIRE”' PAPER EGG BOXES}

These boxes are intended for use in delivering eggs to private families. They are of a very convenient size, are shipped knock-down and can be readily set up.

Net price per doz.

$\$ 0.15$

" " " 25

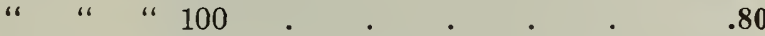

\section{EYRIE SHIPPING COOP}

A Strong, Light Weight Coop for Shipping Fancy Fowls

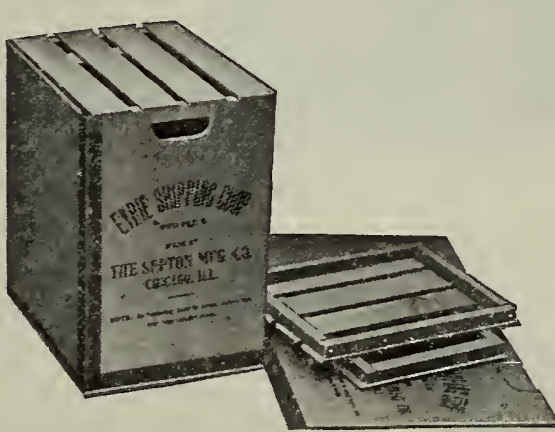

The body is made from extra heavy Corrugated Fibre Board, protecting the $f$ o w $1 \mathrm{~s}$ from draughts, heat and cold. The top and bottom are strongly constructed of wood. They are folded flat for shipment greatly reducing freight and express charges.

\begin{tabular}{|c|c|c|c|c|c|}
\hline No. A & Size & $12 \times 16 \times 18$ & inches & $\begin{array}{r}\text { Each } \\
\$ 0.50\end{array}$ & $\begin{array}{l}\text { Doz. } \\
\mathbf{\$ 5 . 5 0}\end{array}$ \\
\hline "B & & $12 \times 18 \times 22$ & & .60 & 6.25 \\
\hline$" \bar{C}$ & “ & $12 \times 22 \times 22$ & " & .65 & 6.75 \\
\hline$" D$ & " & $20 \times 22 \times 22$ & “ & .80 & 9.00 \\
\hline "E & " & $20 \times 24 \times 22$ & "6 & .90 & 10.00 \\
\hline
\end{tabular}

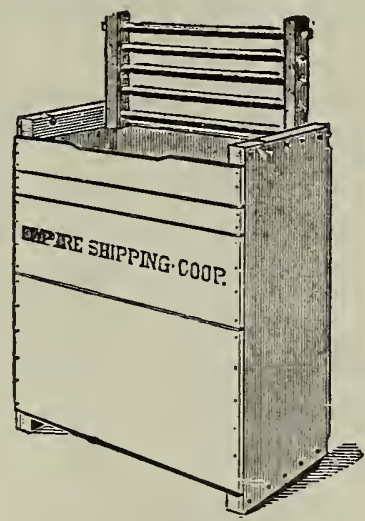

This cut represents the Empire Shipping Coop, with top ventilation. The openings for ventilation are so spaced that birds cannot pass their heads through. An important feature of the coop is the top lid or cover which does not require hammer, saw or nails to coop or uncoop your birds; no matter how often you open or close the coop the top lid or cover is always in position. Coops shipped knocked down can be easily put in position by purchaser.

Single Coop Size, $12 \times 22 \times 25$ inches.

Trio Size, $18 \times 22 \times 25$ inches.

Each

Pen Size, $22 \times 22 \times 25$ inches.

$\$ 0.90$

1.10

1.20

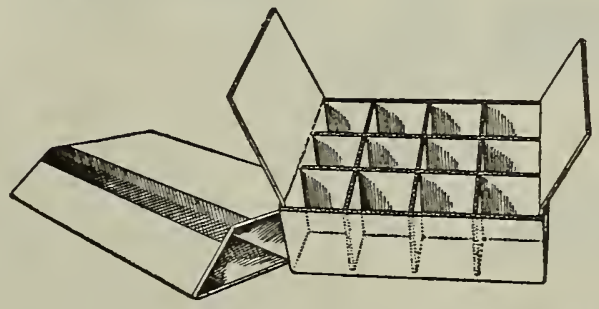

PARCEL POST EGG BOXES
1 Doz. Size. $7 \frac{5}{8} \times 5 \frac{5}{8} \times 2 \frac{5}{8}$ inches.

2 Doz. Size. $7 \frac{5}{8} \times 5 \frac{5}{8} \times 51 / 4$
Per 100 Per Doz.

$\$ 6.00 \$ 0.85$

$7.60 \quad 1.00$

$10.60 \quad 1.40$ 


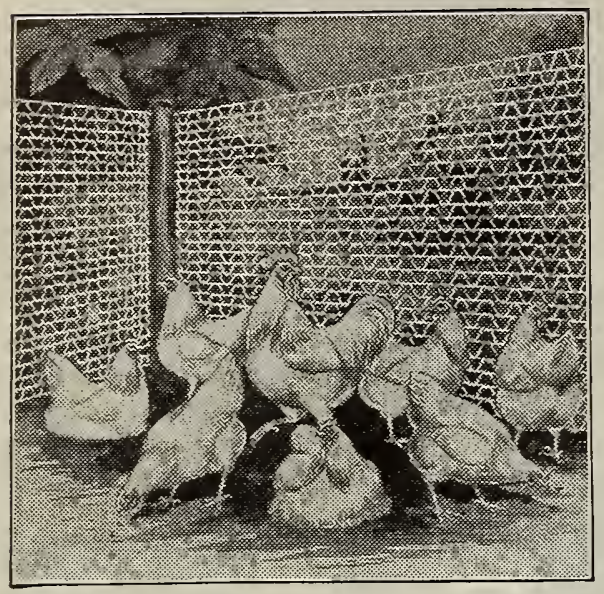

\title{
United States Poultry Fence
}

The United States Poultry Fence is galvanized after weaving and will not rust as Fencing galvanized before weaving.

The United States Poultry Fence has proven the best by test. It has long since established its superiority over other makes, and is in a class by itself. It is built to withstand use and abuse and is guaranteed to give satisfaction.

The United States Poultry Fence is strictly a"No-Sag" poultry fence, as the combination of line and mesh wires, closely woven, prevents any lengthening or narrowing between posts. In erecting United States Poultry Fence the line wires permit of being stretched to a high tension, which compels the fence to remain rigid and upright. These features place it a long stride beyond the Hex Mesh Netting, which never fails to narrow and lengthen if you attempt to stretch it to a tension required to prevent sagging.

No. 19. Wire Poultry Fence, 2-inch Mesh

$12 \mathrm{in.} \mathrm{high,} \mathrm{per} \mathrm{roll} \$ 1.22 \quad 48 \mathrm{in.} \mathrm{high,} \mathrm{per} \mathrm{roll} \$ 4.84$

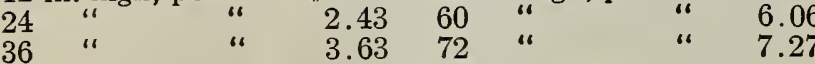

No. 19. Wire Chicken Fence, 1 -inch Mesh

12 in. high, per roll $\$ 2.67 \quad 24$ in. high, per roll $\$ 5.33$

SPECIAL AGENTS FOR PORTLAND

\section{Banner Root Cutter}

\author{
No. 7, Exclusively for Poultry
}

It cuts fast and is easy running. Leaves the feed in fine, brittle, ribbon-like strips that make choking impossible. Fowls large or small can safely eat the feed. The knives are adjustable and made of the very best of steel. An iron gate in bottom of hopper lets dirt and gravel escape before reaching the knives. In this cutter we offer the poultrymen a low-priced, high-grade, nicely finished and mechanically constructed machine. Two to five minutes will cut enough feed for a large flock of fowls.
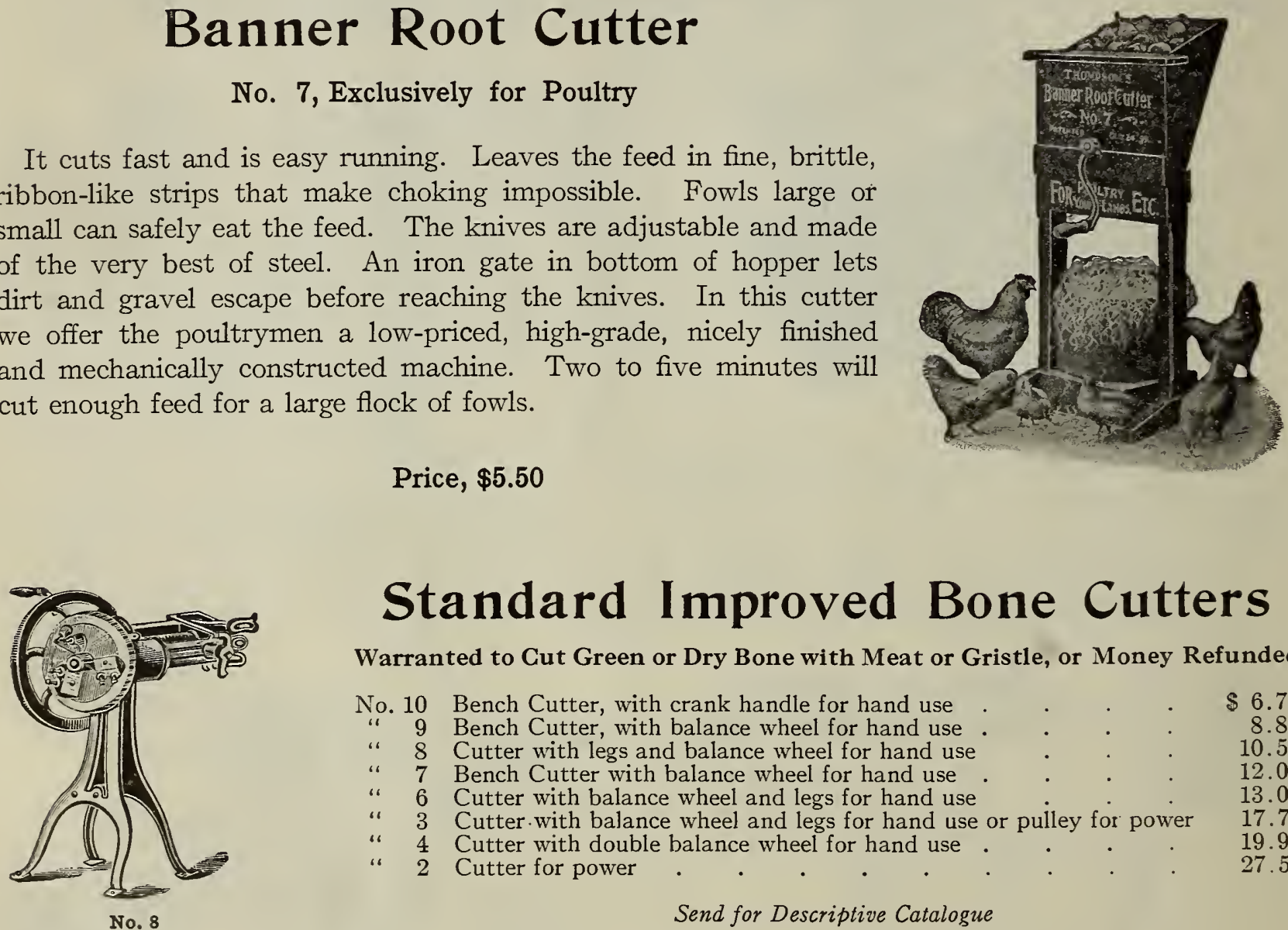

\section{Standard Improved Bone Cutters}

\section{Warranted to Gut Green or Dry Bone with Meat or Gristle, or Money Refunded}

No. 10 Bench Cutter, with crank handle for hand use

$\$ 6.75$

“ 9 Bench Cutter, with balance wheel for hand use

8.80

“ 8 Cutter with legs and balance wheel for hand use

10.50

“ 7 Bench Cutter with balance wheel for hand use .

12.00

" 6 Cutter with balance wheel and legs for hand use

" 3 Cutter.with balance wheel and legs for hand use or pulley for power

13.00

“ 4 Cutter with double balance wheel for hand use

17.75

19.90

" 2 Cutter for power

27.50

Send for Descriptive Catalogue 


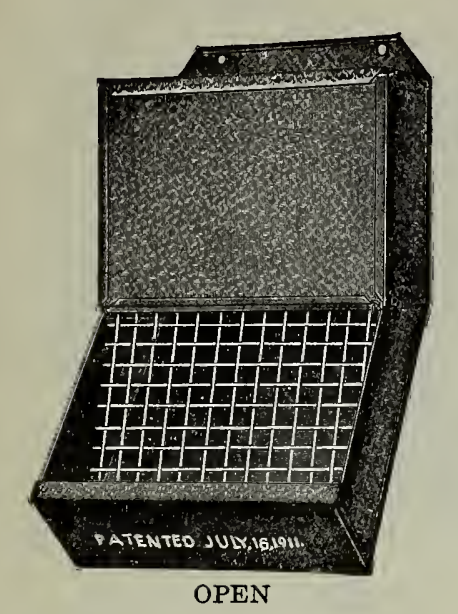

\section{Sexton's Dry Feed Hopper}

Easy to Fill. No Waste. Rat Proof. Dust-Proof.

The lower cover is so arranged that it is held up by locking the top cover of Hopper over same, and by raising the top cover the lower cover will fall in place.

This Hopper is arranged to hang on the wall the desired distance from the floor, and never need be removed from the wall to be refilled. It is impossible to waste any feed, as the pan at the bottom takes any feed that may be picked out and the last crumb can be used, therefore saving any waste. The body being covered keeps feed dust-proof and clean, and is always dry.

Body made of galvanized iron and the grating is of round galvanized wire, preventing the Poultry from cutting their bills. No. $\mathbf{1} \mathbf{\$ 1 . 0 0}$. No. $2, \$ 1.50$.

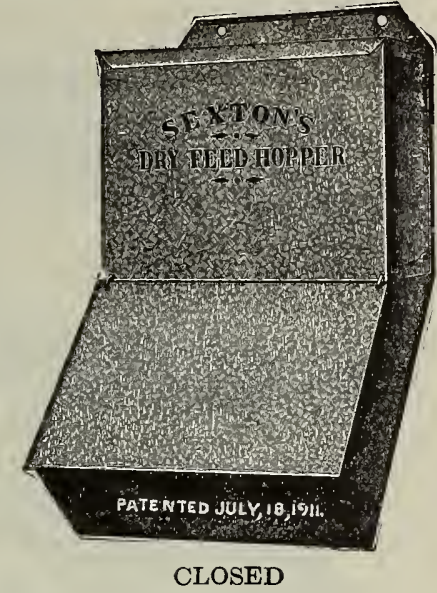

\section{Norwich Automatic Feeder}

Fill the Hopper with any dry grain feed, or any mixture of dry grain feed, and the revolving Bait Bar with cracked corn. Stand the Feeder anywhere in the yard, pen or house, and put any kind of litter under machine. Adjust valve to feed desired quantity. Adjust legs for required height.

The exercise given by the action of the machine is just sufficient to keep the flock in perfect condition. If you are not absolutely satisfied with the machine in every respect, or find one objectionable feature, return it at our expense and we will at once refund your money.

\section{PRICES}

No. 1- 8 Quart Hopper

$$
2-14
$$

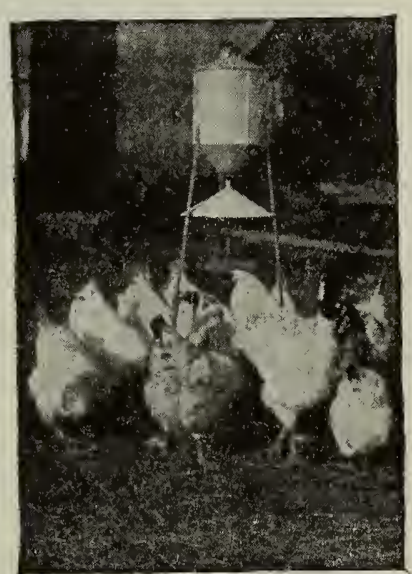

\section{The Apaco Poultry Feeder}

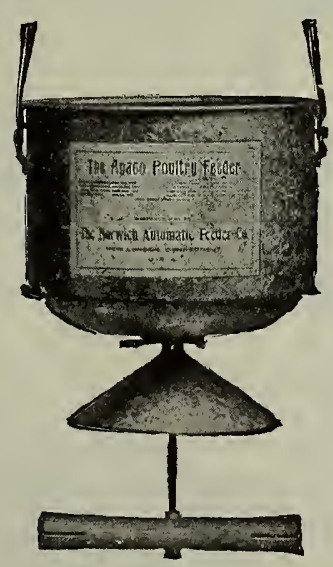

This Feeder in general design is built on the same lines as the well-known Norwich Automatic Feeder, but is a hanging machine rather than arranged with adjustable standard.

The machine is complete with the all-important adjusting valve for regulating the discharge from the hopper, and may be relied upon as a thoroughly dependable and practicable machine.

One size only. 12 quarts capacity. Price $\$ 1.25$ F. O. B. Portland. Parcel Post, weight 5 lbs.

\section{"Overall" Feeders}

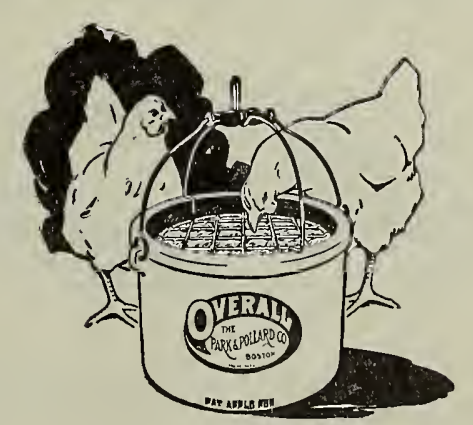

These feeders are made of heavy stoneware, are very strong and durable, easily cleaned and never clog, inexpensive, always accessible, and at the same time the birds cannot waste the feed.

6 quart size, 30c. each.

8 quart size, $40 \mathrm{c}$. each. 


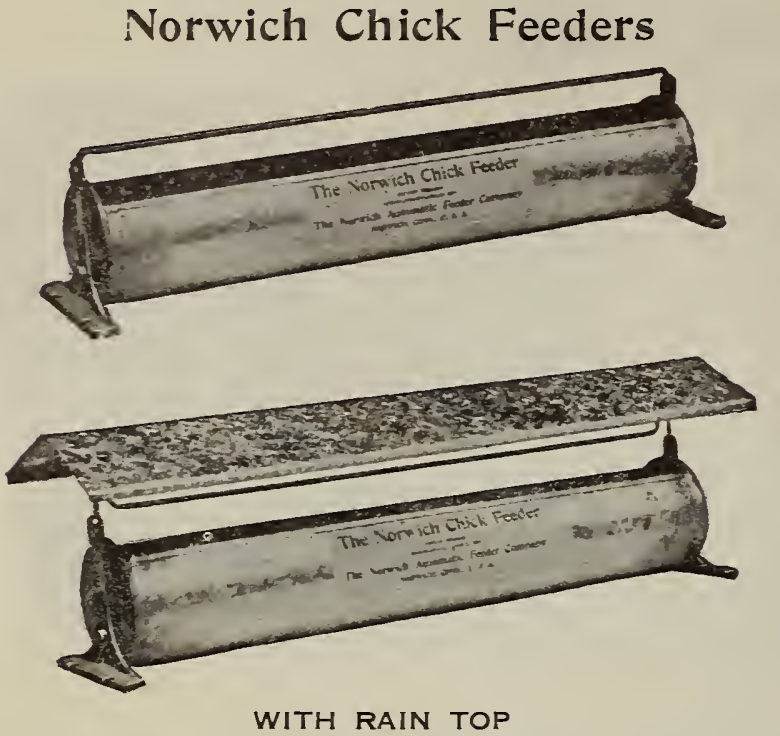

Positively prevents chicks from wasting the mash, and it is impossible for them to get into the feed, thus making it an absolutely sanitary feeder. Top rod removable.

\section{Price List.}

10 in. Parcel Post, weight 15 oz............\$0.25

15 in. Parcel Post, weight 19 oz................. .30

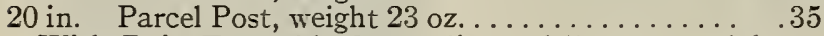

With Rain Top add 10c. to list and $7 \mathrm{oz}$. to weight.

\section{Junior Chick Feeder}

\section{FEEDS DRY MASH \\ OR HARD GRAIN}

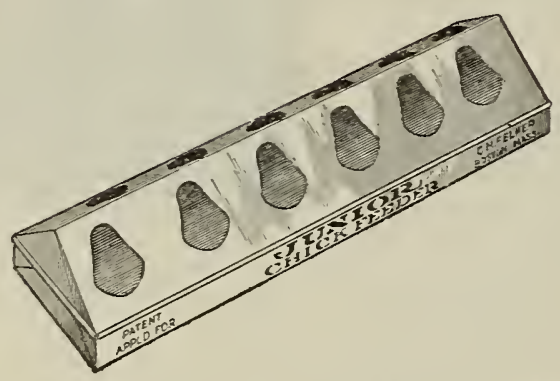

FEEDS SOUR MILK OR WATER

Price, 25c. each. By Parcel Post, 30c.

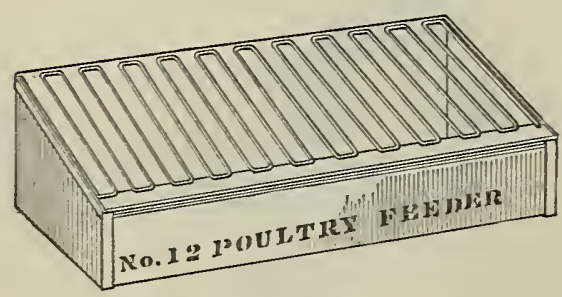

Can be used for any kind of grain and is protected from waste by a specially designed grid. Can be hung on the wall.

No. 12-12 inches Long, 35c. Parcel Post, weight 2 lbs. No. 24-24 inches Long, 50c. Parcel Post, weight 3 lbs.

\section{The Buckeye Self=Feeding Hopper}

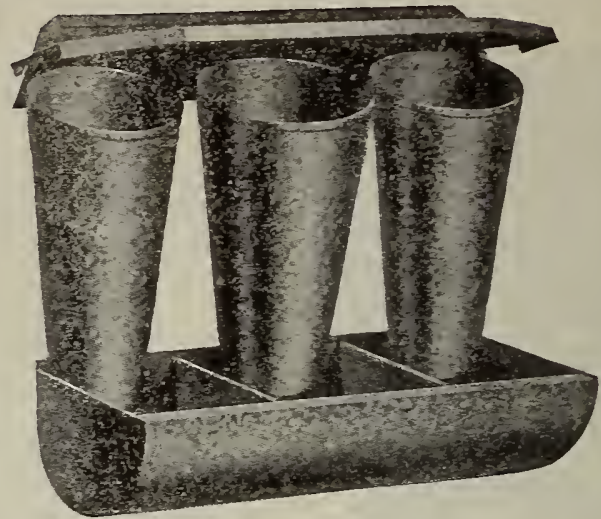

Miade of Galvanized Iron, with three compartmentsfor Shell, Grit and Charcoal. Will not clog. Price, \$1.00. Parcel Post, weight 5 lbs.

\section{"L R" Brooder Chicken Feeders}

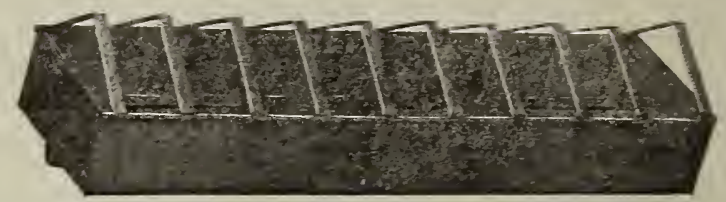

No. 1-10 in. Price 35̌c. Parcel Post, weight 2 lbs. No. 2-18 in. Price 55̃c. Parcel Post, weight 3 lbs.

\section{1=2-3 Poultry Feeder}

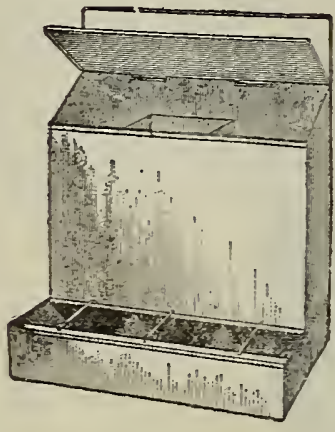

This Feeder is used -for dry mash, scraps, shells, grit, charcoal or any poultry feed.

When used for one kind of feed only, take out separator, two kinds, put separator in one end. When used for three kinds, put separator in middle and you have three separate feeders. Price 50c. Parcel Post, weight 3 lbs.

\section{Pettey's Poultry Punch}
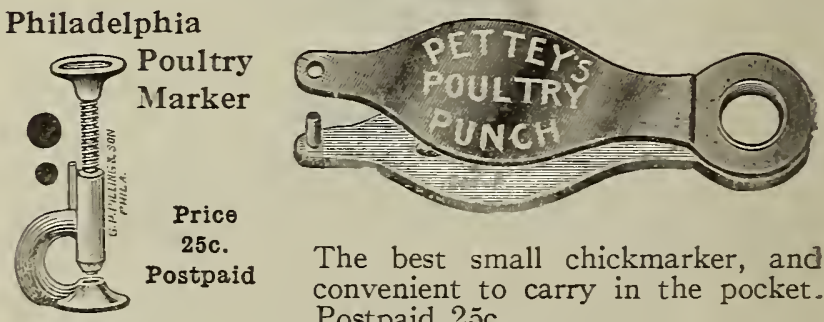

The best small chickmarker, and convenient to carry in the pocket. Postpaid 2j̃c. 

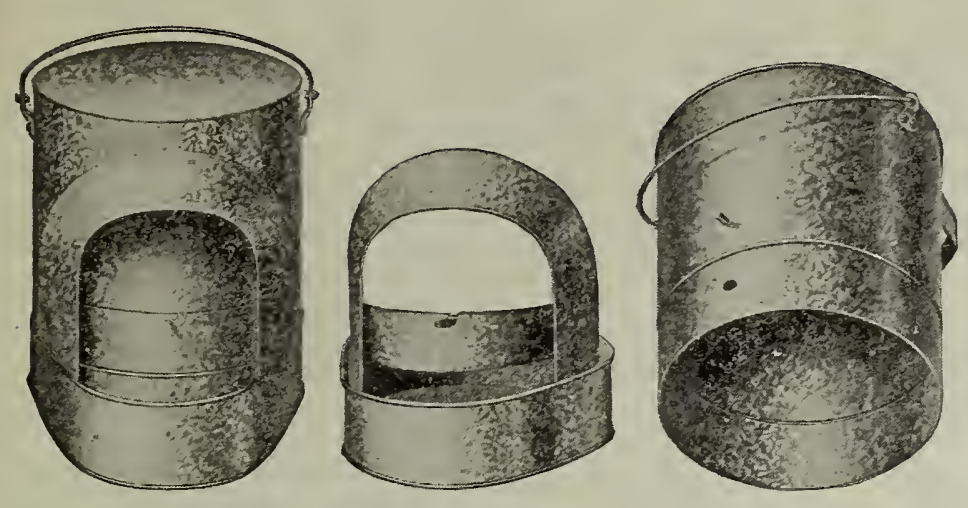

\section{EASY ACCESS POULTRY DRINKING FOUNTAIN}

\section{Made in Two Sections}

It can be easily taken apart and thoroughly cleaned inside; can be filled quickly and easily carried around after filling. Made of galvanized iron, extremely simple, and cannot get out of order. Price, 1 gal, 75c., Parcel Post, weight 3 lbs. 2 gal. $\$ 1.10$, Parcel Post, weight 4 lbs.

\section{THE DUPLEX FOUNTAIN}

\section{Norwich Automatic Air=Lock Fountain}

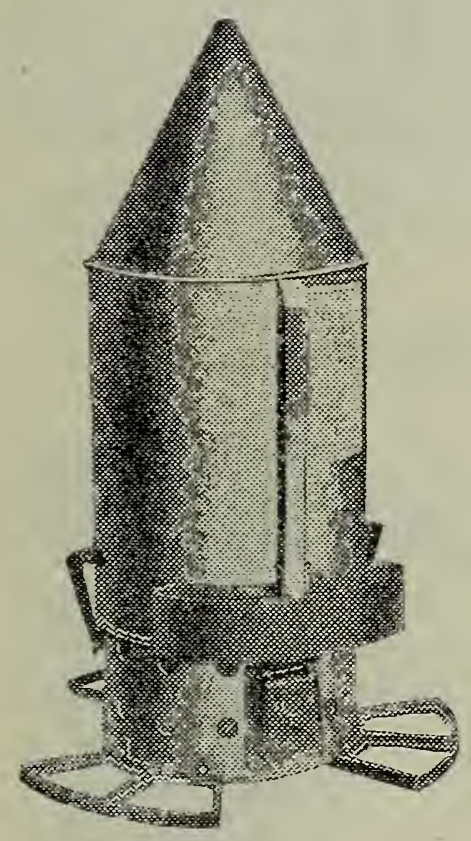

The most perfect device ever placed on the market for automatically supplying pure, fresh water in the poultry house. It is a physical and absolute impossibility to contaminate or pollute the water supply, and requires cleaning about once in three months, only.

Guaranteed frostproof to ten degrees below zero.

Made in one size only, 5 gallons capacity.

Complete with Burner Base, $\$ 4.00$.

Without Burner Base, $\$ 2.50$. lbs.

Mailing weight, 17

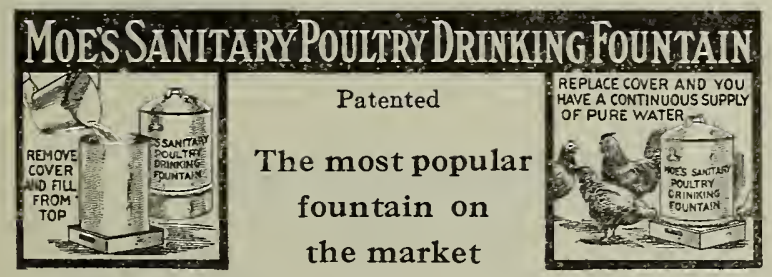

Fills from the top. Dead air space keeps water cool in summer and from freezing in winter.

No. 1, 1 gallon size, $\$ 1.00$. Mailing weight, 4 lbs.

No. 2, 2 gallon size, $\$ 1.50$. Mailing weight, $6 \mathrm{lbs}$.

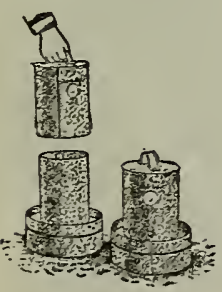

Andrews' Drinking Fountain. A sanitary and practical automatic fountain.

1 gallon size......... $\$ 1.00$

2 gallon size......... 1.60

Mailing weights 4 and 6 lbs.

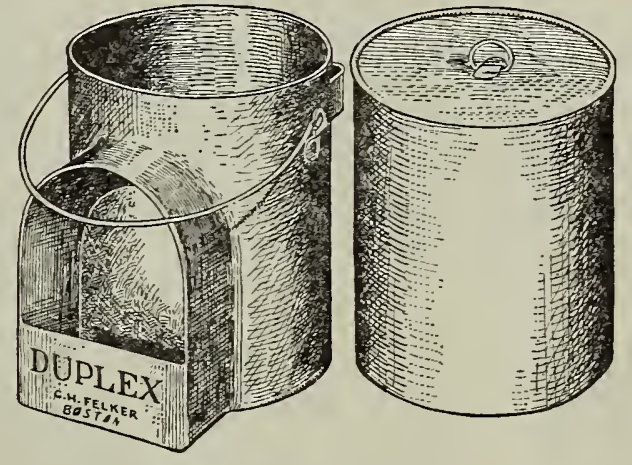

The latest and most practical sanitary fountain on the market. This is a double fount, keeps the water clean and pure. Easy to fill. Easy to care for. 4-qts. 60c., Parcel Post, weight 3 lbs. 8-qts. 85c., Parcel Post, weight 4 lbs.

\section{The Peerless Brooder Fountain}

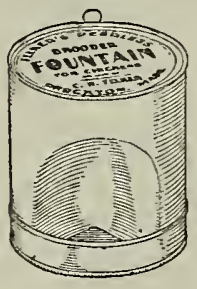

It is the ideal fountain for small chickens. Easy to fill and easy to clean.

Price, 30c.

Mailing weight, 2 lbs.

\section{Stoneware Fountains}

They keep the water cool, and it is impossible for chickens to get drowned. 1 qt. 25 c., 2 qts. 30 c.
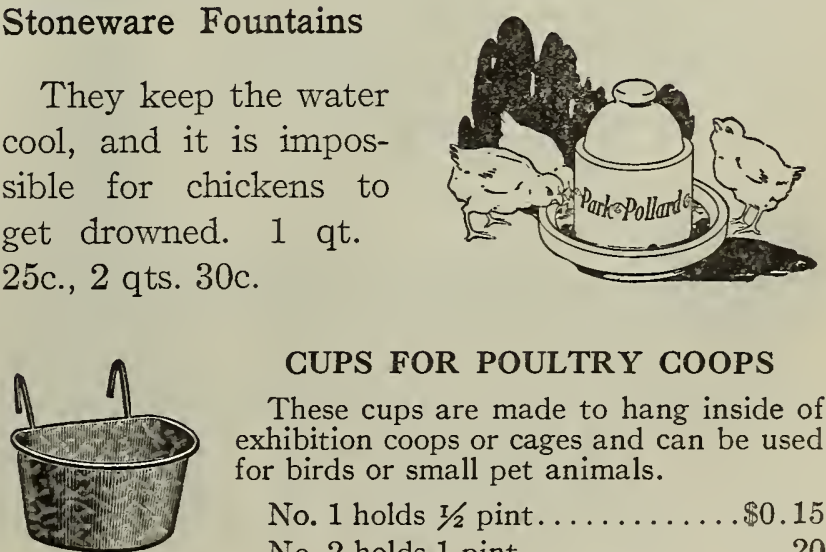

\section{CUPS FOR POULTRY COOPS}

These cups are made to hang inside of exhibition coops or cages and can be used for birds or small pet animals.

No. 1 holds $1 / 2$ pint.........\$0.15

No. 2 holds 1 pint. .......... . 20 


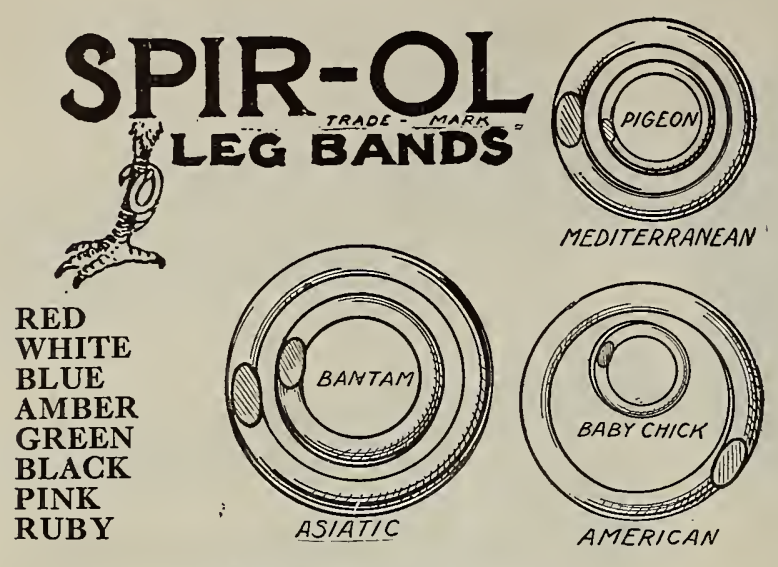

Made of Celluloid

Identify birds as far as you can distinguish colors. Indestructible and can be slipped on and off like a key ring. Sample free. Poultry sizes: 12 for $15 \mathrm{c}$., 25 for $30 \mathrm{c}$, 50 for $50 \mathrm{c}$., 100 for $75 \mathrm{c}$, postpaid. Baby Chick Bands: 25 for $20 \mathrm{c}$., 50 for $35 c ., 100$ for 50c., Postpaid.

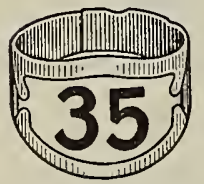

\section{THE VICTOR BAND}

\section{In Colors with numbers}

Made in celluloid and aluminum. Adjustable. Entirely new and different from all others. Large printed numbers, bright and clear colors. Red, blue, white, yellow and green. Prices: Prepaid by mail: 12 for 35 c., 25 for 60 c., 50 for $\$ 1.10,100$ for $\$ 2.00$.

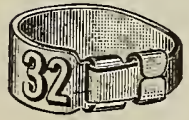

\section{CAPITAL LEG BAND Made in Celluloid}

It is instantly adjustable to the size of the leg. It locks with a double clamp, fits the leg perfectly, and once on, stays on, until you remove it. The Figures are Raised or Embossed and are always clear and distinct. Supplied in consecutive numbers to suit purchaser.

Prices: Prepaid by mail, 12 for $15 \mathrm{c}$., 25 for $25 \mathrm{c}$., 50 for 40 c., 100 for 65 c., 250 for $\$ 1.50$.

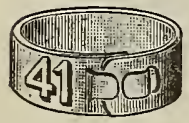

\section{FAVORITE LEG BAND}

This is a popular aluminum leg band with RAISED FIGURES, and can be supplied in consecutive numbers as desired. It is easily attached, and, when in place, cannot be lost off in continuous wear.

Prices: Prepaid by mail, 12 for 15 c., 25 for 25 c., 50 for $40 \mathrm{c}$., 100 for $65 \mathrm{c}$.

\section{Start Oats Sprouting}

The feeding of sprouted oats is no longer an experiment. By feeding sprouted oats through the winter, egg production can be kept up to a much larger degree than otherwise.

\section{ANDREWS' OAT SPROUTER}

The outer walls are constructed of the best grade of Poplar Lumber, lined with asbestos, and on the inner walls galvanized lining is used; thus where moisture and heat is prevalent on the inside, galvanized lining is used, but on the outside, where the sprouter is subject to change in weather, wood is used, with asbestos lining, to make the heat more uniform.

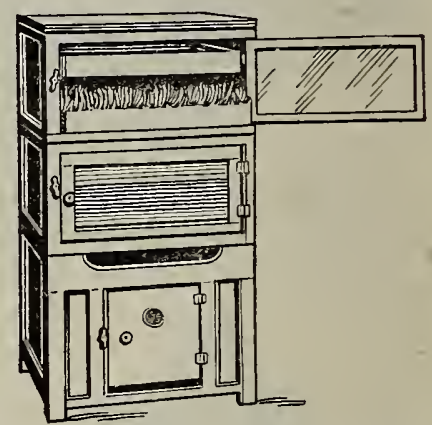

Capacity Outfit "B." Lamp Chamber; 2 sections; 4 trays; holds 20 quarts; recommended for flock of from 100 to 150 . Price, $\$ 10.75$.

\section{Economy Oat Sprouter}

This Sprouter employs the natural process for sprouting. No heat necessary.

The Tray contains five Sprouting Pans and one Drip Pan 16x17 inches.

Made of galvanized iron-will not rust.

Price ............... \$5.50

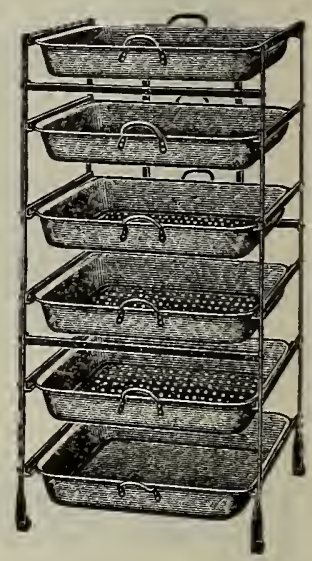

\section{NESCO BROOD COOP}

(Galvanized.)

Declared by chicken experts to be as near perfect as can be made in meeting poultry requirements.

This coop is specially fine for setting hens. It keeps them confined and undisturbed by other fowls or rats.

Bottom Diam. .20 in. Height.... 183/4 in. Price ....... $\$ 2.00$

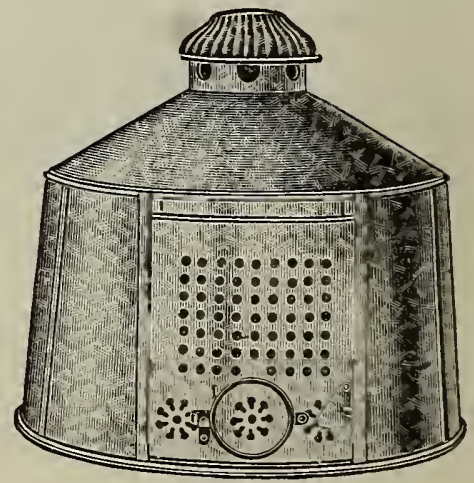




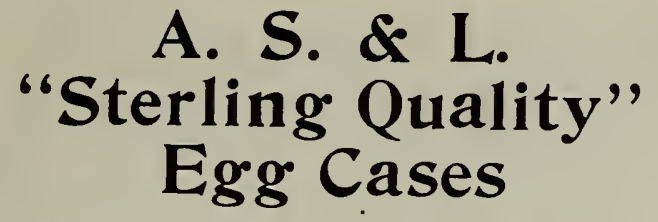

The most complete Egg Case on the market, largely used by shippers, and constructed to stand Rough Handling in Transit

\section{8 dozen \\ 15 " . . . . . . . 1.00 \\ 30 \\ 49 \\ 56 \\ "Pittsburgh Perfect" Chicken, Rabbit and Poultry Fences}

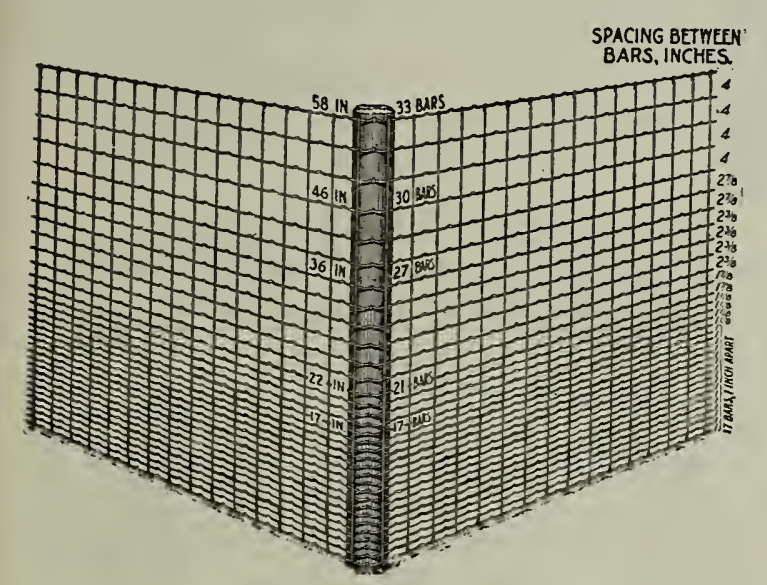

"Here is a combination of 'Pittsburgh Perfect' Fence styles whose field of usefulness and perfect adaptability outclass by far any other fences made for similar purposes."

"They give to poultry quarters, gardens, etc., a smart, up-todate appearance, and are the most durable and thoroughly satisfactory poultry fence possible to procure. It is unnecessary to use a top board with any of these fences, as we employ an extra heavy top and bottom wire, which also adds greatly to strength. A top board gives the chickens a chance to see how high they have to fly to get over, and if no board is used they will not fly over. For about a foot and a half from the ground the line wires are only an inch apart, while the stay wires are placed either four or six inches apart."

Made in six different heights, offering many economical advantages.

\section{Write 'for Prices}

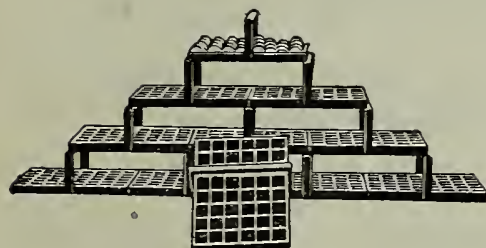

\section{Buckeye Egg Tester}

Made of tin to fit either B or C Burner.

Makes a strong, powerful light for the egg so that any person can easily determine the fertility. 25c. each, Postpaid.

\section{STERLINGWORTH WATER GLASS}

Put your eggs down in the spring and summer, when they are cheap, and keep them fresh for ten months. One gallon makes sufficient solution for 50 dozen. It has been thoroughly tested. Do not trust eggs to water glass of inferior strength. IVater glass must be pure and strong to safely protect eggs.

Sterlingworth Water Glass is first quality.

Prices: 1 quart 25̃c., mailing weight, 5 lbs.; 1 gallon 75c., mailing weight, 15 lbs.; 5 gal. cans $\$ 2.50$ each; 10 gal. cans $\$ 4.50$ each.

\section{Wire Hen's Nest}

Supported on Walls by hooking over two nails.

Each, 15c., Per doz. $\$ 1.25$
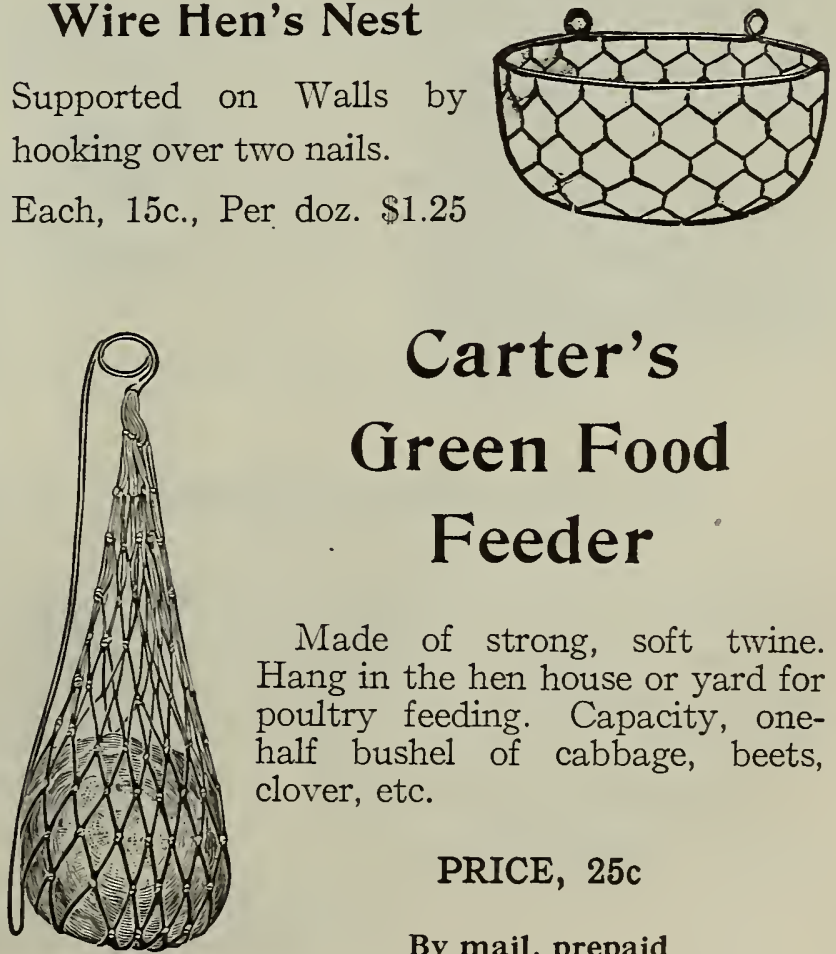

Made of strong, soft twine. Hang in the hen house or yard for poultry feeding. Capacity, onehalf bushel of cabbage, beets, clover, etc.

PRICE, 25c 


\section{DR. HESS POULTRY AND STOCK}

Prescriptions by Dr. Hess, M. D., D. V. S.

\section{Dr. Hess Poultry Pan $=\mathbf{a}=\mathbf{c e}=\mathbf{a}$}

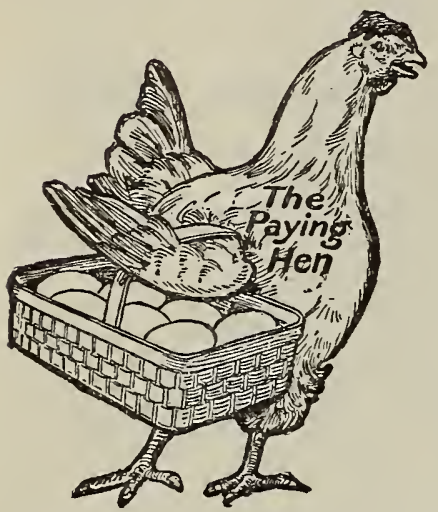

Makes p o u 1 t r y healthy; makes hens lay; not a stimulant, but a tonic that tones up the dormant egg organs, brings $\mathrm{b}$ a c $\mathrm{k}$ the scratch and cackle and compels each hen to put her share of eggs in the market basket.

It also contains internal antiseptics that

counteract disease; insures a healthy, singing poultry flock. Costs but a trifle-a penny's worth enough for thirty hens per day.

$1 \mathrm{~T} / 2$ 1bs. 25c.; 5 lbs. 60c.; 12 lbs. \$1.25;

25 lb. pail $\$ 2.50$

GUARANTEED

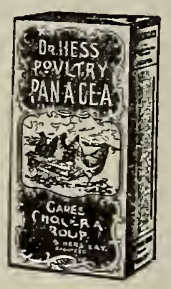

\section{Dr. Hess Stock Tonic}

Formula printed on every package

Every ingredient indorsed by the U. S. Dispensatory and other high medical authorities. It aids digestion, makes stock healthy, and expels worms. Helps stock convert more ration into milk, flesh, blood and muscle. Every pound backed by the Dr. Hess \& Clark unqualified guarantee.

PRICES, $251 \mathrm{lb}$. pail $\$ 2.00$

100 lb. drum $\$ 6.50$

\section{Dr. Hess Worm Powder}

For horses, sheep, cattle and hogs. It is highly concentrated and is an effective vermifuge. Dr. Hess own prescription that proved effective in his practice.

PRICE, 11/2 lbs. 50c.

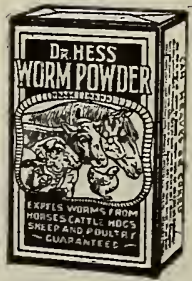

\section{Dr. Hess Instant Louse Killer}

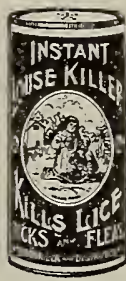

Kills lice on poultry, horses, cattle; sheep ticks; bugs on cucumber, squash and melon vines; cabbage worm, slugs on rose bushes, etc. Sold in siftingtop cans. Look for the word "Instant" before buying.

PRICE, $1 \mathrm{lb} .25 \mathrm{c}$. 3 1bs. 60c. GUARANTEED

\section{Dr. Hess Dip and Disinfectant}

Non-poisonous and non-irritating, and guaranteed to be absolutely uniform in strength at all times. One gallon of Dip makes from 70 to 100 gallons effective solution. Spray it on roosts. Sprinkle it over the runs and in all cracks and crevices. Spray it on cattle and horses.

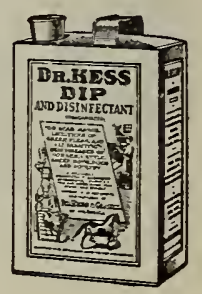
Makes a splendid dip for hogs and sheep. It's a sure parasite and disease germ destroyer. Purifies stables, troughs, sinks, drains.

Pt. 25c., Qt. 40c., 2 Qts. 60c., Gal. $\$ 1.00$ GUARANTEED

\section{Dr. Hess Healing Powder}

The modern gall cure. Cures galls,

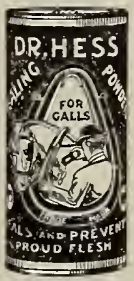
cuts, wounds, ulcers, grease heel. Antiseptic and soothing. Heals everything it touches by forming a coating, cleaning and closing up wounds.

Comes in sifting-top cans.

PRICE, 4 oz. 25c; 10 oz. 50c.

\section{Absolutely Guaranteed}

\section{Dr. Hess Heave Powder}

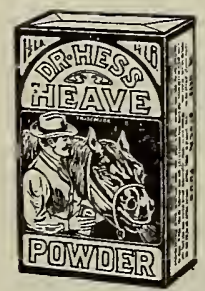

A dependable preparation for relieving horses of heaves, chronic coughs, asthma, bronchitis, etc ; with careful diet, the frequent use of this valuable preparation will afford permanent relief in the majority of cases.

PRICE, $11 / 2 \mathrm{lb}$. package $50 \mathrm{c}$.

\section{Dr. Hess Colic Remedy}

A reliable preparation for the treatment of spasmodic and flatulent colic, gripes, acute or chronic indigestion, impaction of the stomach, bowel inflammation, etc.

PRICE, 50c. and \$1.00. Guaranteed 


\section{Conkey's Buttermilk Starting Food}

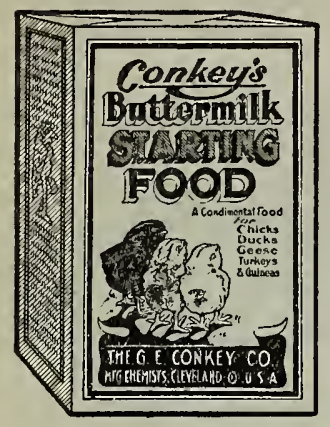

Buttermilk your baby chicks and make them grow like weeds. Put vim and vigor into them when they most need it; help them throw off disease and withstand exposure. Conkey's Buttermilk Starting Food provides buttermilk for the chicks in a dry, sanitary form. It makes a regular, uniform supply possible, and in addition to this it contains sweet, pure grains and just enough medication to start the organs working in a normal way. It is a nourishing, stamina-building food that makes the youngsters husky and strong. One pound will feed twelve chicks for three weeks.

Pkgs., 25c. and 50c.; bags-14 lbs. \$1.00, 25 lbs. $\$ 1.75,50$ lbs. $\$ 3.25$, 109 1bs. $\$ 6.00$.

\section{CONKEY'S ROUP REMEDY}

CONKEY'S GANKER SPECIAL

25c., 50c. and $\$ 1.00$

CONKEY'S CHOLERA REMEDY

50c. and $\$ 1.00$

25c. and 50c.

CONKEY'S SOREHEAD (Chickenpox)

REMEDY 25c. and 50c.

CONKEY'S BRONCHITIS REMEDY 50c.

CONKEY'S GAPE REMEDY 25c. and 50c.
CONKEY'S WHITE DIARRHOEA REMEDY

CONKEY'S POULTRY TONIC

25c. and 50c.

Pkgs. 25c., 50c. and $\$ 1.00$

CONKEY'S LICE POWDER

Pkgs. 10c., 25c. and 50c.

CONKEY'S LICE LIQUID

Qt. 35c., 2 qts. 60c.

CONKEY'S NOXICIDE

Pt. 35c., qt. 60c., 2 qts., 90c.

French's Poultry Mustard insures healthful and proper conditions at all times. This is not ordinary table mustard, but is prepared for poultry alone. Feed a teaspoonful for every six fowls; mix with dry meal, then add water. Price, 11/2-1b. pkg. 40c.; 3-1b. pkg. 70c.; 5-1b. pkg. \$1.10; 10-1b. pkg. $\$ 2.00 ; 25-1 b$. pail, $\$ 4.50$.

\section{JAPROID ROOFING}

This roofing in built on a base of heavy wool felt, thoroughly saturated and coated with pure Gilsonite Asphalt. The high grade quality of felt gives this roofing a tensile strength which renders it practically indestructible under ordinary conditions.

The heavy saturation of pure Gilsonite Asphalt, the best waterproofing product known, renders this roofing absolutely impervious to heat or cold, and waterproof to the most perfect degree.

It is made 36 inches wide, put up in rolls containing 108 square feet, sufficient to cover 100 square feet, allowing for a 2-inch lap.

Prices: Per Roll, 1 ply, $\$ 2.00 ; 2$ ply, $\$ 2.25 ; 3$ ply, $\$ 2.50$.

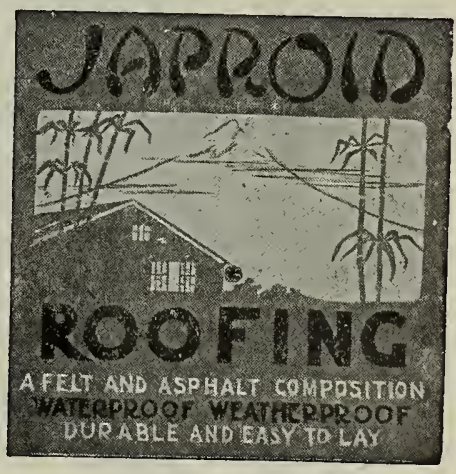

\section{STERLINGWORTH POULTRY GHARCOAL}

Charcoal aids digestion, promotes health, and is generally corrective of many poultry ills. No poultry raiser can afford to be without it.

XX (Fine Granulated) for Chicks and Chick Food Mixtures.

XXX (Medium Granulated) for Half-Grown Fowls, Pigeons, etc.

XXXX (Coarse Granulated) for Grown Fowls, Geese, Turkeys, etc.

Prices: 50-1b. paper lined burlap sacks, $\$ 1.00$ each. 2-1b. cartons, $15 \mathrm{c}$. each. 


\section{Andrews Efficiency Baby Chick Carriers}

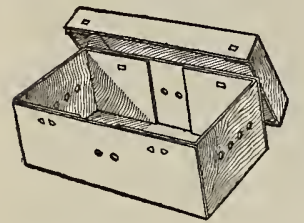

These boxes are made of jute fibre board, water-proof inside and out

$\begin{array}{rlrrr}25 \text { chicks } & \text { Size } 13 \frac{3}{4} \times 8 \times 5 \frac{3}{8} \text { inches } & \text { Each } & \text { Doz. } & \$ 1.20 \\ 50 \text { chicks } & \text { Size } 14 \frac{3}{4} \times 14 \times 5 \frac{3}{8} & \text { “ } & 15 \mathrm{c} & 1.70 \\ 100 \text { chicks } & \text { Size } 26 \frac{3}{4} \times 15 \times 5 \frac{3}{8} & & 25 \mathrm{c} & 2.90\end{array}$

Carbola. The Disinfectant that Paints.

Carbola is superior to lime, which loses what slight disinfecting qualities it ever had by slacking when exposed to the air. It is a snow white, cold water paint that will not blister, flake or peel off, combined with a germicide twenty times stronger than carbolic acid, but neither caustic nor poisonous. Can be applied with either sprayer or brush.

Price: Trial pkg., postpaid 35c., by express $25 \mathrm{c}$; $10 \mathrm{lb}$. pkg., by express $\$ 1.00 ; 20 \mathrm{lb}$. pkg., by express $\$ 2.00$; $50 \mathrm{lb}$. pkg. $\$ 4.00$.

\section{Russell Poultry Killing Knife}

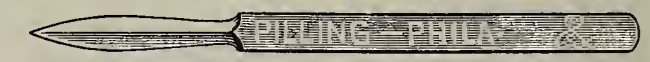

\section{French Poultry Killing Knife}

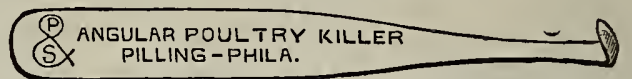

\section{Angular Poultry Killing Knife}

Price of each of the above Knives, 50c. postpaid.

\section{NEST EGGS}

Porcelain. Each, 3c., doz. 20c. Lime (medicated), each 3c., doz. 25c. Add 8c. per doz. if wanted sent by mail.

\section{YOUNG'S RAT DESTROYER}

Young's Rat Destroyer has a charm for rats the same as catnip has for cats. It has a corrosive effect on the linings of the stomach, and is harmless to larger animals in the small quantities eaten by rats or mice. Its action upon rats is slow, and they usually leave the premises in search of water.

Price, 25c. express collect; (cannot be sent by mail). 40c. by express prepaid.

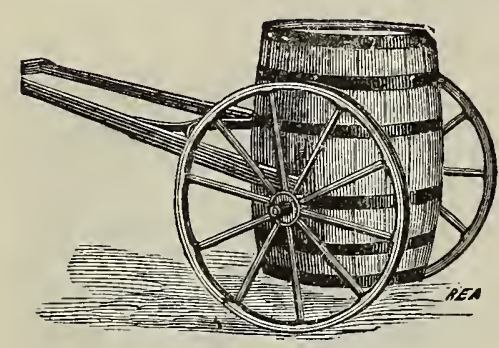

\section{Water Barrel Trucks}

\section{Water Barrel, Hand Cart, Leaf Rack}

Adjustable to One Truck

All easily attached

Truck with $1 \frac{1}{2}$ in. tire $\$ 8.00$

Truck with $2 \frac{1}{2}$ in. tire $\quad 8.50$

Truck with $3 \frac{1}{2}$ in. tire $\quad 10.75$

Sprinkler attachment $\$ 4.00$

\author{
Barrels \\ Box for cart \\ Leaf Rack
}

Extra trunnions, per pair $\$ .70$

\section{New England Root Cutter}

\section{With Separate Crank and Balance Wheel}

The great advantage of feeding cattle and sheep during the winter months partly on vegetables has become generally recognized. It is necessary, however, to properly cut the Roots so as to prevent choking, and to make them easy of digestion.

We have in this cutter one which will do the work in every way acceptably, and for which only a small price is charged.

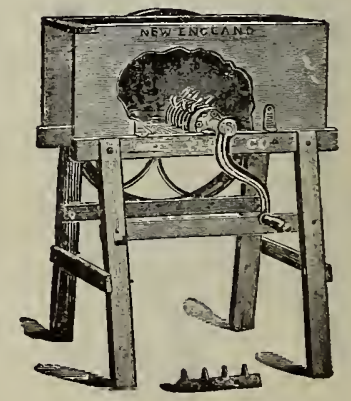




\section{EGGS FOR HATCHING}

At short notice we can furnish Eggs from reliable breeders

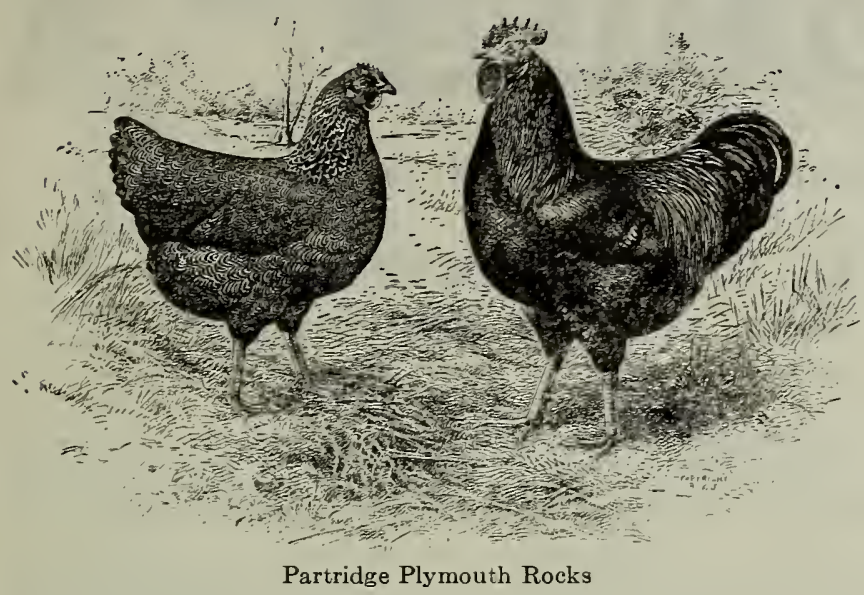

DAY OLD CHICKS

A great many poultry keepers, especially those in a small way, prefer to buy the young chicks to the trouble of hatching. To meet this demand we furnish good lively chicks in all the ordinary breeds at reasonable prices.

\section{WATERPROOF SHEETING}

Use waterproof sheeting in the windows of your hen house in place of glass. Then there will always be a circulation of pure, dry air and no steam, as caused by glass. You will notice that the Experiment Stations use it. 15c. per yard.

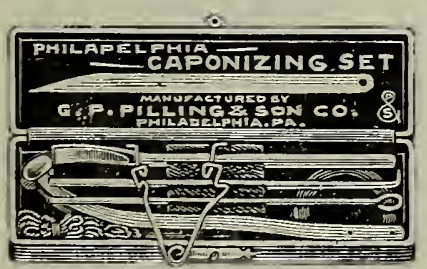

\section{The Philadelphia Caponizing Set}

Complete, with instructions.

Price, $\$ 2.50$
Plymouth Rock (Barred, Buff and White)

White Wyandotte

Rhode Island Red

Leghorn (White and Buff)

Orpington (Black, Buff and White)

Buttercups

Partridge Plymouth Rock

(The Beauty-Utility Breed)
Setting of $13 \mathrm{Eggs}$

$\$ 1.25$ to $\$ 3.00$

1.25 to 3.00

1.25 to 3.00

1.50 to 3.00

2.50 to 5.00

5.00

2.00 to 5.00
We shall be pleased to quote special prices for eggs in large quantities for incubators

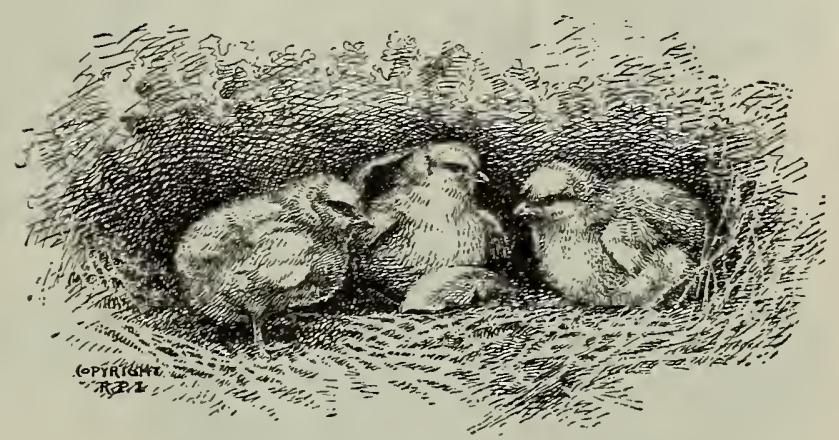

\section{Pine Tree Shipping Crates}

Made of Green Elm, then thoroughly dried. The round corners prevent injury and loss by crowding, so frequent in square cornered crates. Price, $\$ 1.25$.

\section{Sulphur Candles}

Kill insect pests and disease germs

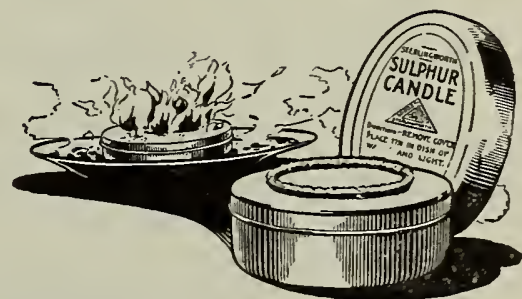

The Candles are especially useful in ridding poultry houses, dog kennels, etc., of insect pests, as the vapor from them penetrates crevices not reached by other means. Price, 10c. each; postpaid, 15c.

\section{STERLINGWORTH FISH FOOD}

An imported cereal wafer food prepared especially for feeding gold fish. Each wafer is $23 / 4 \times 33 / 4$ inches and about the thickness of blotting paper. Price, per box, (20 sheets), 10c., postpaid. Per doz., $\$ 1.00$ postpaid.

Box sufficient for several flocks, 50c., postpaid. 


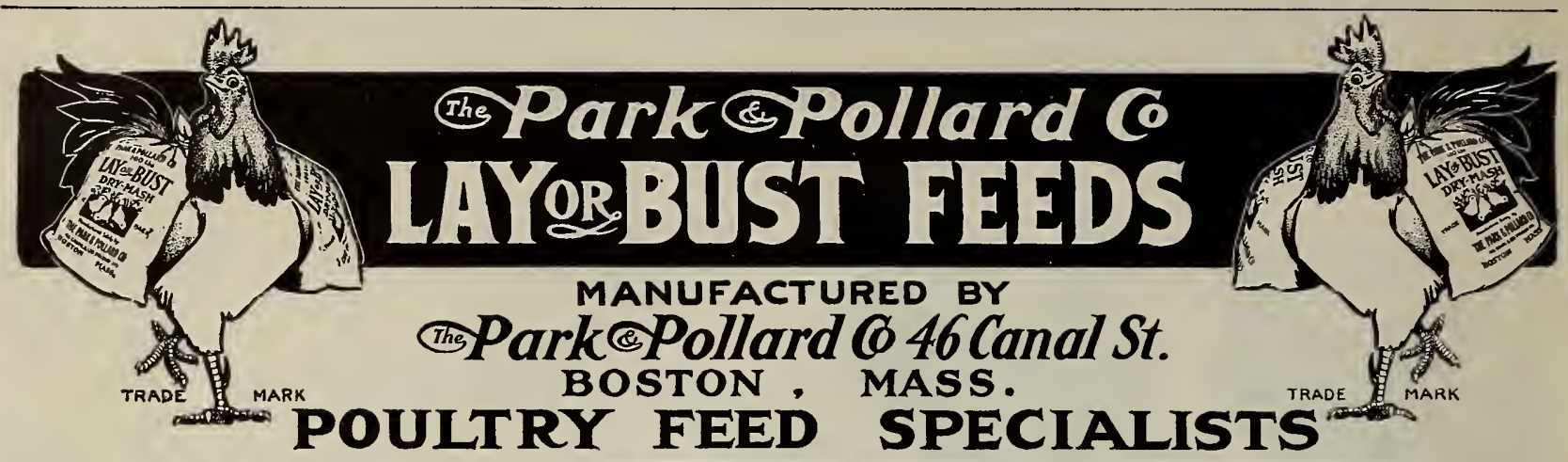

TAKEN FROM "THE PARK \& POLLARD CO., YEAR BOOK AND ALMANAC" (re) Park \& POII Ard C LAY OR BUST-Dry-Mash

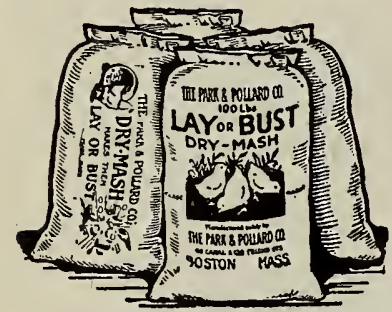

When we tell you that Park \& Pollard Dry-Mash makes them "lay or bust" every time, at all seasone of the year, we mean what we say. It is as impossible for a healthy ben to eat "Lay or Bust" and not lay as for half a dozen women to sweep back the tide in Boston Harbor. Not only does it produce eggs at a lower cost than any other feed, but it maintains the birds in better health and does away with more than one-half cost than any other feed, but

Many of the ailments of Poultrydom are directly traceable to improper feeding. Egg eating, feather pulling, too much broodiness, over-fatness, diarrhoea, constipation, crop-bound, slow moulting, pale combs. poor fertility, weak germs, low vitality in young chicks, soft-shelled eggs are all due to improper diet, and we have corrected the tendency to all of them in our mixtures, and have demonstrated that these ailments are largely overcome by the use of Park \& Pollard feeds. These points are given constant and careful consideration by us, and the requirements followed out regardless ot the cost of the proper materials.

A fluctuating grain market does not mean that high-priced ingredients necessary to the proper balancing of our feeds will be left out of our mixtures; this would be poor economy for you and for us.

Lay or Bust will give you the results you are looking for every day in the year

\section{שe Park \& POIIARd C SGREENED SGRATGH FEED}

Scratch Feed is a supplementary ration; that is to say, the eggs or the growth, are in the Lay or Bust and the growing Feed; the Scratch Feed, or hard feed. only serves to balance and fll out the ration

There is no question that by using Park \& Pollard Lay or Bust Feed in conncetion with most any Scratch Feed you will obtain better results than you have ever gained before, but if you wish to obtain the very highest egg yields and maintain your flock in the highest state of health by all means feed both Lay or Bust_and Park and Pollard screened scratch feed.
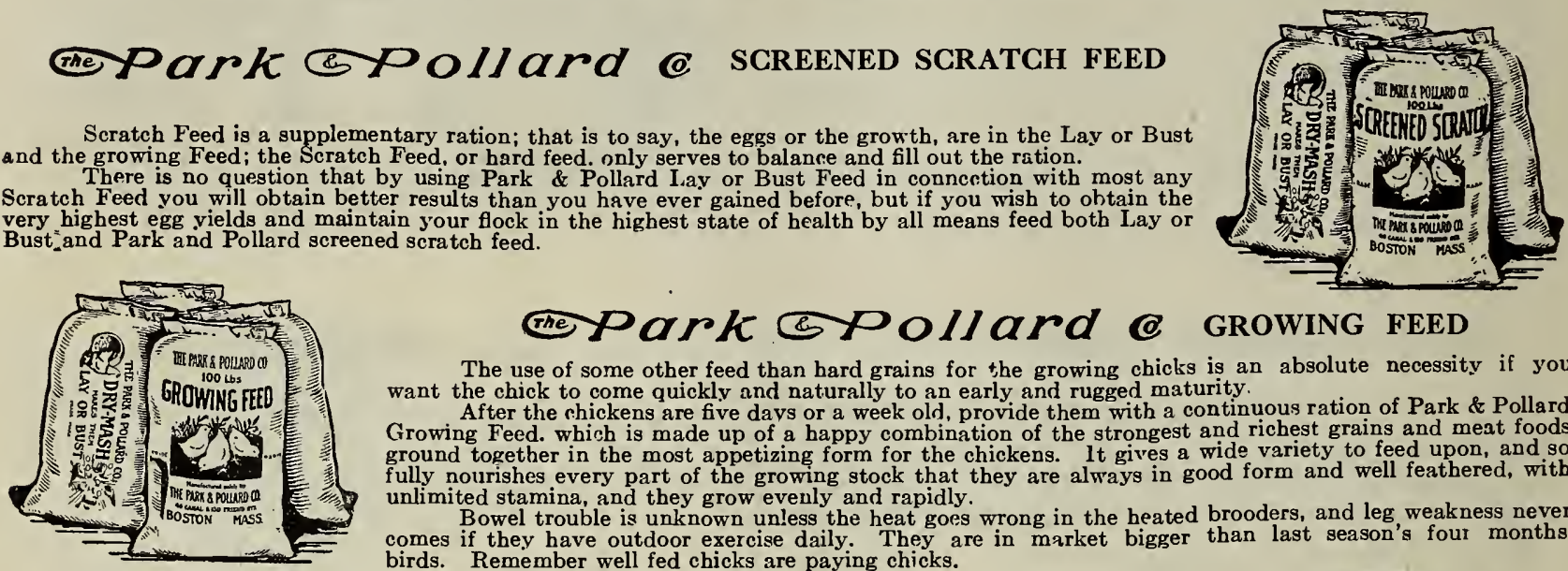
want the chick to come quickly and naturally to an early and rugged maturity. Growing Feed. which is made up of a happy combination of the strongest and richest grains and meat foods ground together in the most appetizing form for the chickens. lt gives a wide variety to feed upon, and so fully nourishes every part of the growing stock that they are always in good form and well feathered, with unlimited stamina, and they grow evenly and rapidly.

Bowel trouble is unknown unless the heat goes wrong in the heated brooders, and leg, weakness never comes if they have outdor exercise daily. They season's four months" birds. Remember well fed chicks are paying chicks.

\section{The Parkespollard e}

BABY BUSTER CHICK

FEED

If the chickens consumed the chick feed in the first month of their lives in the quantities they use when from three to five months of age, there might be a little excuse for poultrymen looking for less expensive rations, provided it did not imperil the lives of the youngsters, but when we consider that a pound of the best chick feed will put a chicken beyond the danger period, or up to three weeks of age, what excuse is there for the saving of a quarter of a ent a pound when it en, or the you save on one hundred chicks you would lose in the death of one. When you have so much at stake, why you save on one hundred chi
use any thing but the best?

This feed contains fish as in previous years, as, with each additional season, we have found that fish is a wonderful vitalizer and strength promoter in the youthful days of the chicken's life.

Order it by its name!- "Baby Buster" Chick Feed.

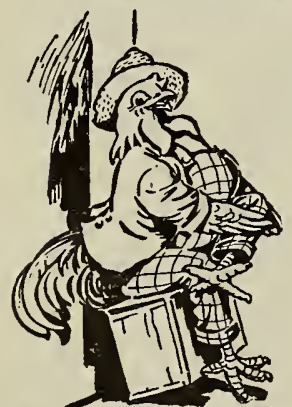

The Park \& Pollard Co.

Gentlemen: - I have been feeding your feed all the year and have had great success. I house my birds in open front houses and feed them according to your system.

Very truly yours,

(Signed) CHARLES E. OLIVER

R. F. D. 4. Box 6, Brunswick Me., May, 1915

The Park \& Pollard Co.

Gentlemen:- There is no use to question the value of your Growing Feed for young chicks here. I have a flock of $97 \mathrm{R}$. I. Reds and the smallest weight is $1 \mathrm{lb}$. and $9 \mathrm{oz}$. and only 5 weeks old. I think this is pretty good. All your feeds bave a large place in my feed room. They cannot be equalled.

Yours truly,

(Signed) ERNEST BARIBEAU.

Perth Amboy, N. J., Jan. 19, 1915

The Park \& Pollard Co.

Gentlemen:-As one who has from time to time used your "Lay or Bust" with excellent results, I would like to ask you for two of your Year Books and Almanacs. They have been to me in the past not only an excellent memo book but a guide and a companion in raising and caring for my birds. Thanking you, I remain Yours very truly 


\section{The Waters' Butter Worker}

The WATERS' Butter Worker is the best dairy worker manufactured and the favorite among dairymen. The tray has the bottom made of one clear piece of selected cypress board. It can be instantly removed and used as a butter bowl if desired. The castings are all heavily galvanized. The butter worker comes equipped with hardwood stand, as illustrated.

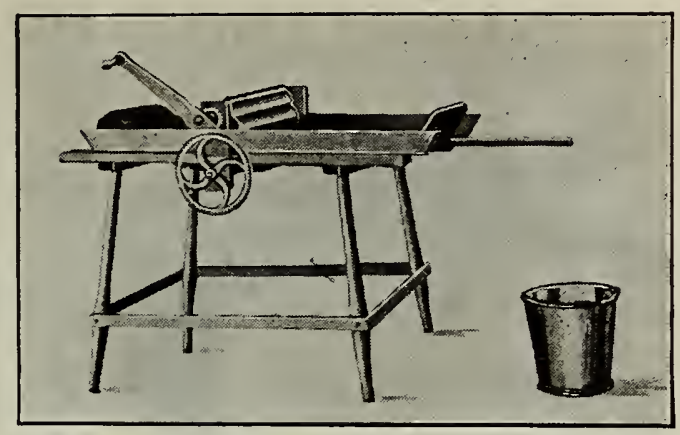

\begin{tabular}{|c|c|c|c|c|c|}
\hline Size & Length of Tray & Width of Tray & Lbs. Capacity & Cows & Price \\
\hline No. 0 & 27 inch & 14 inch & 1 to 15 & 1 to 4 & $\$ 7.00$ \\
\hline No. 1 & $36 “$ & $15 "$ & 5 to 30 & 4 to 8 & 8.00 \\
\hline No. 2 & $36 "$ & 18 “" & 5 to 40 & 8 to 12 & 9.00 \\
\hline No. 3 & 39 “ & 20 & 5 to 50 & 12 to 18 & 10.00 \\
\hline No. 4 & 48 “ & 22 & 10 to 75 & 18 to 30 & 12.00 \\
\hline
\end{tabular}

\section{The Kinerson Combination Butter Prints}

These Butter Prints are largely used and give perfect satisfaction; practical, simple and durable.

Prints engraved to order with simple design, initial or monogram, without extra charge.

For special design a small advance on the list will be charged.

A paddle and two cutters are furnished with each print.

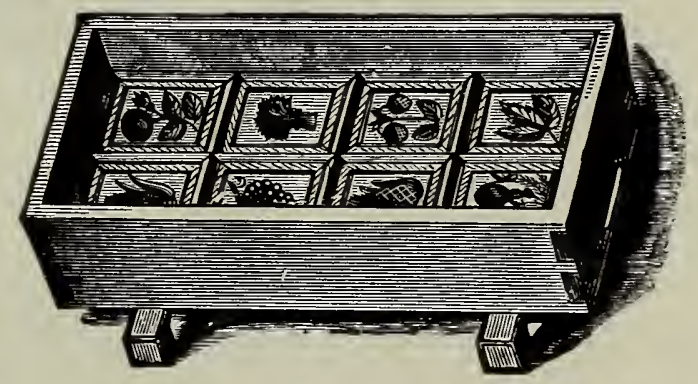

No. 6 Print

\begin{tabular}{|c|c|c|c|c|c|c|}
\hline No. of Print & No. of Cakes & $\begin{array}{l}\text { Capacity of } \\
\text { Moulds in lbs. }\end{array}$ & $\begin{array}{l}\text { Capacity of Each } \\
\text { Cake in ounces }\end{array}$ & $\begin{array}{l}\text { Dimensions of } \\
\text { Moulds in inches }\end{array}$ & $\begin{array}{c}\text { Dimensions of } \\
\text { Each Cake }\end{array}$ & Price \\
\hline 2 & 4 & 2 & 8 & $11 \times 33 / 4$ & $33 / 4 \times 23 / 4$ & $\$ 4.50$ \\
\hline 3 & 4 & 2 & 8 & $12 \times 3$ & $3 \times 3$ & 4.50 \\
\hline 4 & 4 & 1 & 4 & $41 / 2 \times 5$ & $2 \mathrm{I} / 4 \times 2 \mathrm{I} / 2$ & 4.25 \\
\hline 5 & 4 & 1 & 4 & $10 \times 2^{1 / 2}$ & $21 / 2 \times 21 / 2$ & 4.50 \\
\hline 6 & 8 & 2 & 4 & $10 \times 4^{1} / 2$ & $21 / 4 \times 21 / 2$ & 5.25 \\
\hline 10 & 24 & $11 / 2$ & 1 & $10 \times 4$ & $11 / 4 \times 1 \frac{1}{3}$ & 6.00 \\
\hline 12 & 8 & 4 & 8 & $11 \times 5$ & $23 / 4 \times 21 / 2$ & 5.25 \\
\hline
\end{tabular}

\section{Blanchard Butter Moulds}

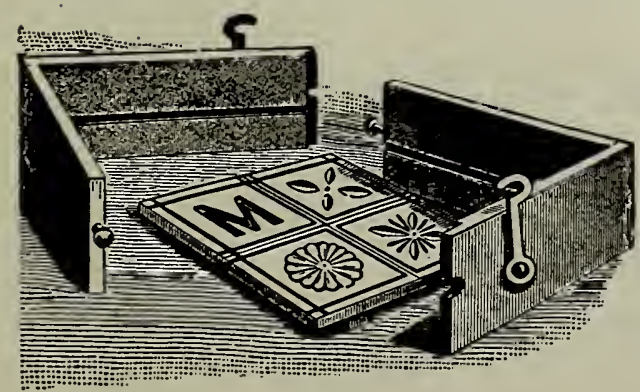

$1 / 2$ Pound, 2-1/4 lb. Prints, Parcel Post, Weight, $1 \mathrm{lb} . \quad \$ 0.40$

1 Pound, $4-\mathrm{r} / 4 \mathrm{lb}$. Prints, Parcel Post, weight 2 lbs. $\quad .50$

2 Pound, $8-\mathrm{I} / 4 \mathrm{lb}$. Prints, Parcel Post, weight 2 lbs. $\quad .75$

Initial Engraved, 25 cents extra 


\section{“STERLING” PRINT BUTTER CARRIERS}

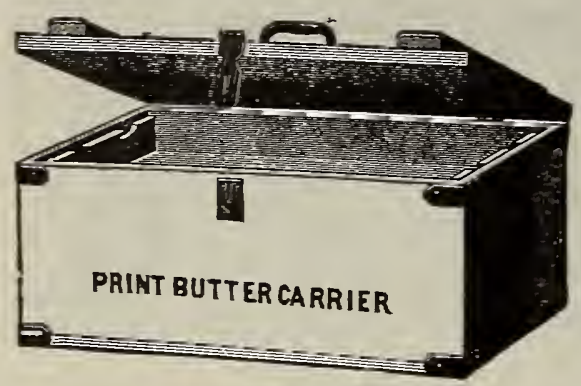

The boxes and trays are made of white wood, and have no taste or smell. They are strong and durable, and will carry the butter in good condition.

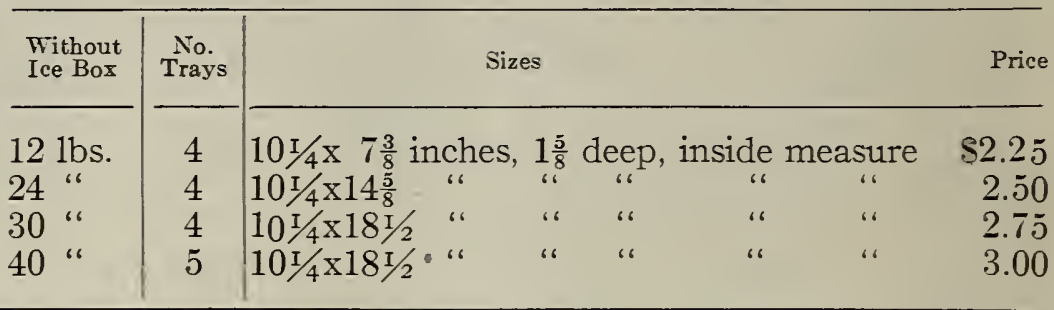

\section{Parchment Butter Paper}

For wrapping and covering butter, for layers and caps on top of tubs, jars, tumblers, etc.

Price, 25c. per lb. By parcel post, prepaid, 30c., per lb.

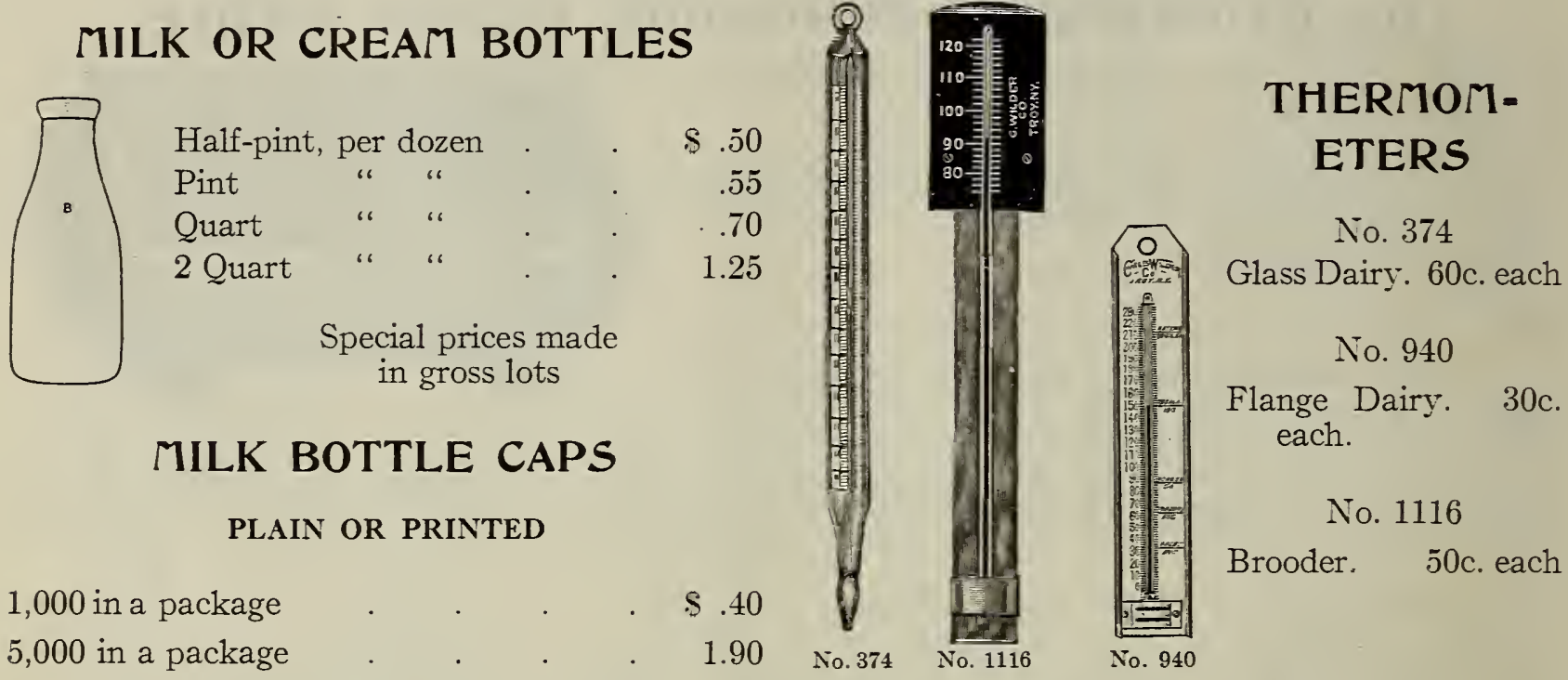

\section{Milk Bottle Carriers}

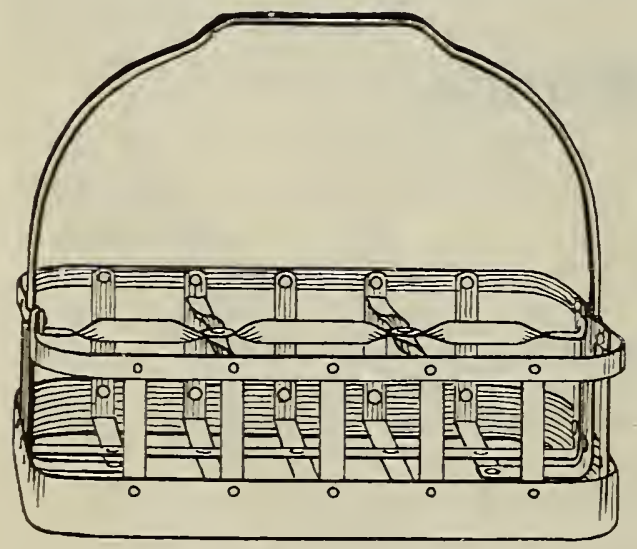

Style C, Milk Bottle Carrier
Style C Carriers are made of rolled ribbon steel with steel band around bottom, the edge of which is $1 / 4$ inch below the bottom of basket, which protects the bottom from wearing out as fast.

Price 6 Bottle (Quarts)Style C,

\footnotetext{
". . . . . . . . . 1.75

" (with lower partition for qts. or pts.) 1.75

" (with lower partition for qts. or pts.) 2.00

" (round wire) 


\section{THE STODDARD CHURN}

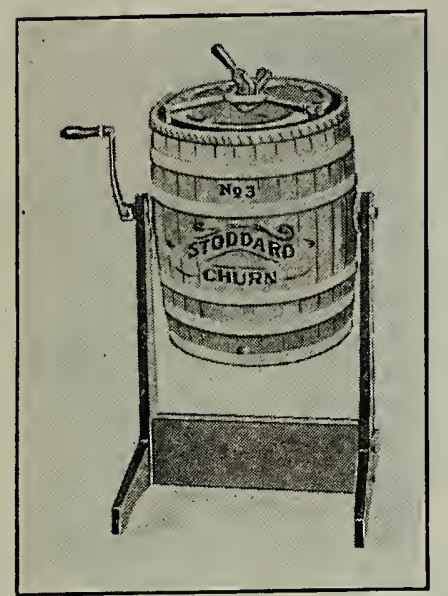

The STODDARD Barrel Churn is the Best and most popular dairy churn on the market. It is the only churn manufactured with all castings, including hoops, heavily galvanized so they will not rust.

\section{Prices, Dairy Sizes, Hand Power}

No. 1. 10 Gals., churns 2 to 4 gals. . . . . . . $\$ 10.00$

No. 2. 15 Gals., churns 2 to 7 gals. . . . . . . 10.50

No. 3. 20 Gals., churns 3 to 9 gals. . . . . . . 12.00

No. 4. 25 Gals., churns 4 to 12 gals. . . . . . . 14.00

No. 5. 35 Gals., churns 5 to 16 gals. . . . . . 16.00

No. $5 \frac{1}{2} 45$ Gals., churns 5 to 20 gals. . . . . . 20.00

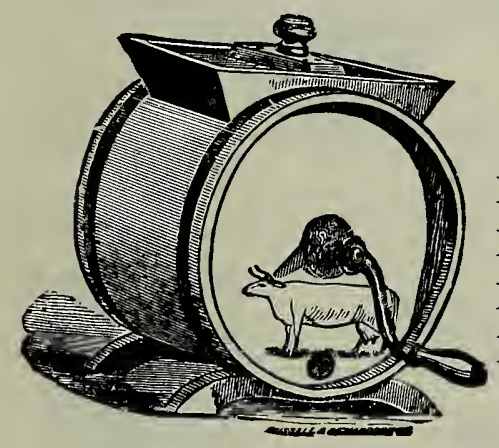

\section{Cylinder Churns}

No. 1. 3 Gallon Capacity

$\$ 2.00$

No. 2. 4 Gallon Capacity

2.50

No. 3. 7 Gallon Capacity

3.00

No. 4. 10 Gallon Capacity

3.50

Folding Paper Butter Boxes

1 Pound (2 Pieces)

Price, $\$ 1.00$ per 100

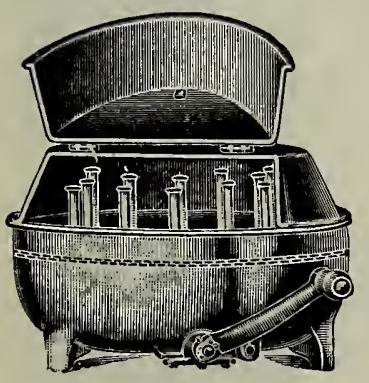

\section{The "Facile" Improved Babcock Milk Tester}

The "FACILE" Hand Tester is very compact, and is the most favored apparatus, in small compass, for testing milk: Price includes a full set of glass ware, comprising test bottles, pipette, acid measure; also bottle brush and bottle of test acid.
2-Bottle Machine
$\$ 4.00$
6-Bottle Machine
$\$ 9.00$
4-Bottle Machine
5.00
8-Bottle Machine
10.00

\section{Champion Milk Cooler and Aerator}

Milk cooled as soon as milked makes more and better butter and cheese. Not only cools the milk, but completely aerates it, removing all offensive flavors.
No. 2.
Capacity of Milk Receiver
Size of Dairy
18 Quarts
10 to 25 Cows
Takes Care of
Price
No. 3 .
34 Quarts
25 to 50 Cows
3 Milkers
$\$ 6.00$
5 Milkers
6.50

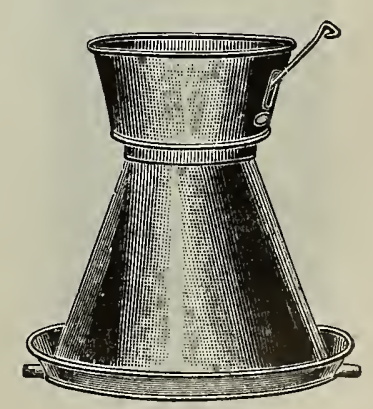




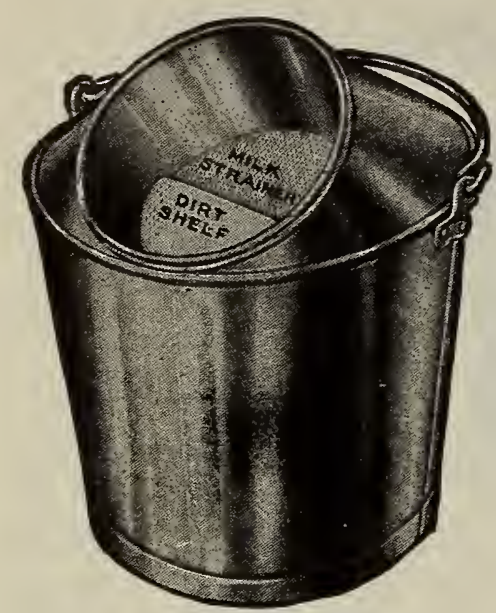

STERILAC SANITARY MILK PAIL

Note the strainer cloth on which the milk strikes.

Note the dirt shelf which catches the dirt falling from the udder. The projecting to $p$ shields the strainer cloth from falling dirt. It is easy to use, because the opening is of ample width.

It does not spatter. Price, $\$ 2.50$

Price, seamless $\$ 3.00$

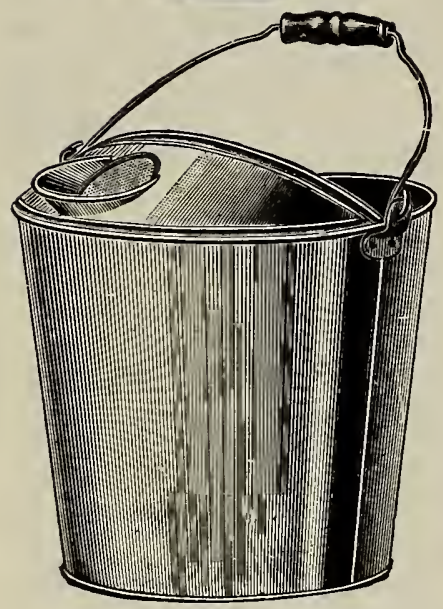

\section{Portland} Dairy Pail

14 Quart, Price, $\$ 1.00$

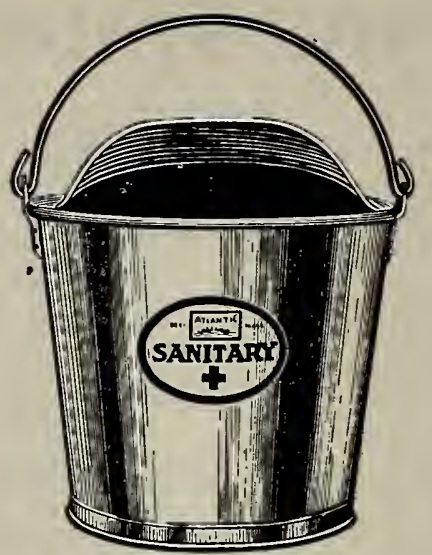

Atlantic "Sanitary" Dairy Pail

Soldered Inside and Outside

14 Quart, Price, $\$ 1.50$

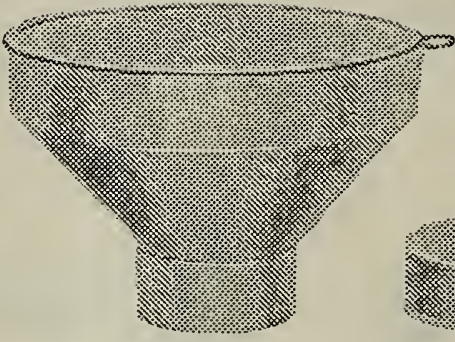

SANITARY

MILK STRAINERS

With extra slip foot for cloth.

$\begin{array}{rlllllll}3 \text { Quart } & - & - & - & - & - & - & \$ 0.75 \\ 6 \text { Quart } & - & - & - & - & - & - & 1.00 \\ 10 \text { Quart } & - & - & - & - & - & - & 1.25\end{array}$

\section{Milk and Cream Scale}

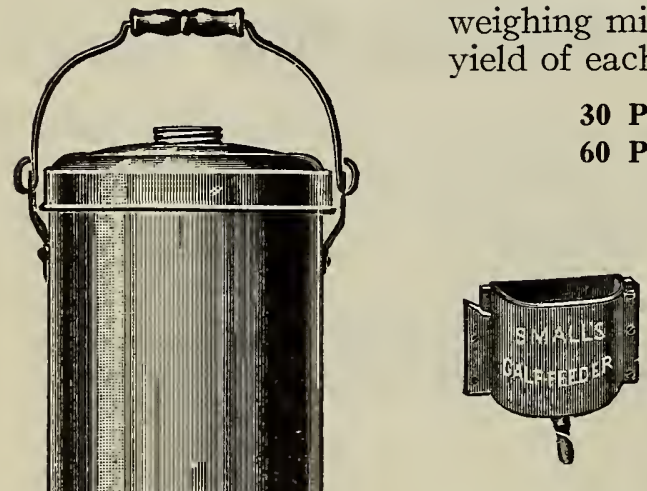

SMALL'S CALF FEEDER

Price, $\$ 2.50$

Extra Nipples 25c. each

\section{Milking Tubes}

For Sore and Obstructed Teats and Hard Milking Cows

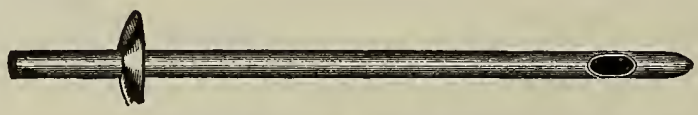

Price, Postpaid, 25c.

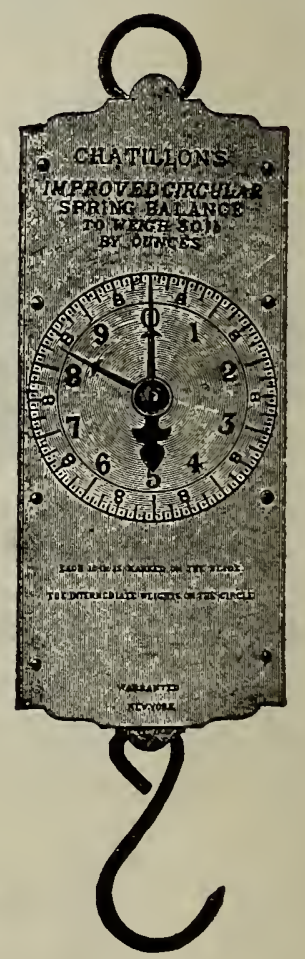

Milk Scale less. 70-Mesh Brass
Strainer Cloth. $\$ 0.75$ 1.25

Creamery Pail

Price, \$1.75 


\section{THE NEW}

\section{SHARPLES}

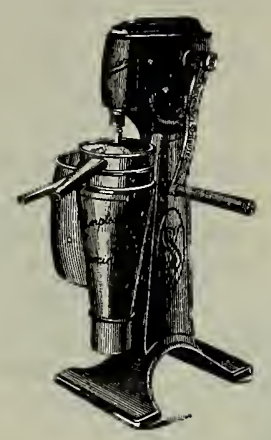

SUCTION-FEED

TUBULAR

CREAM SEPARATOR
The New Sharples Suction-feed Separator saves $50 \%$ in cost of operation, in labor of cleaning, in oil and in repairs and it saves $A L L$ the cream. The New Sharples requires no speed indicators. It skims clean and produces cream of uniform density at any speed. 28 new features never before used in cream separator construction are represented in the New Sharples Suction-feed Tubular. It is absolutely automatic in its feeding, skimming and separating functions and, even in the hands of a beginner, it cannot lose butterfat or produce uneven cream.

Handsome New Catalogue Sent Free On Request.

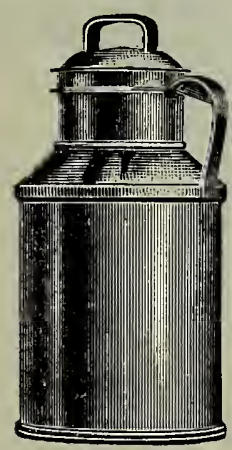

\section{MILK CANS}

We can furnish any style or size

Write for quotations

\section{GRANGE GARGET CURE}

Cures garget without in any way injuring the cow or lessening the flow of milk.

Price 50c. per can

\section{IDEAL EAR BUTTON}

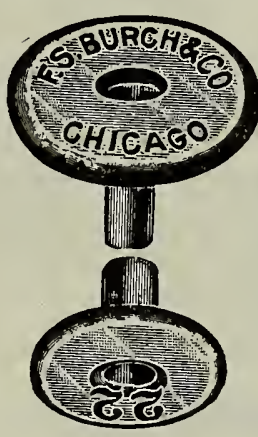

Absolutely the best on the market

Clinches tight. Does not come out. Double tube gives double strength. Name and address on top, as shown, and number on bottom. Pure aluminum.

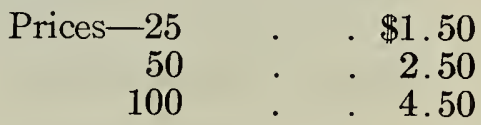

Postage prepaid

Name and address, not exceeding 18 letters, can be put on top cap.

\section{KOW=KURE}

\section{The Great Medicine for Cows only}

It acts upon the digestive, generating and milksecreting organs, keeping the entire system toned up and in perfect working order.

Price 50 c. and $\$ 1.00$ per can 
NOT AN

EXPERIMENT

BUT

PRACTICAL

AND

EFFICIENT

WRITE TO US

FOR EMPIRE CATALOGUE
THIS CUT SHOWS TWO-COW UNIT ONE-COW UNITS SUPPLIED IF PREFERRED

Only one pipe line needed. Pipe line easily run wherever conrenient along cow stalls.

Operated by small, simple, quiet, light running vacuum pump driven by any suitable power. No compressed air used. Pulsating action relieves and massages teats. No air, dust or odors come in contact with milk. Milk does not pass through pulsator.

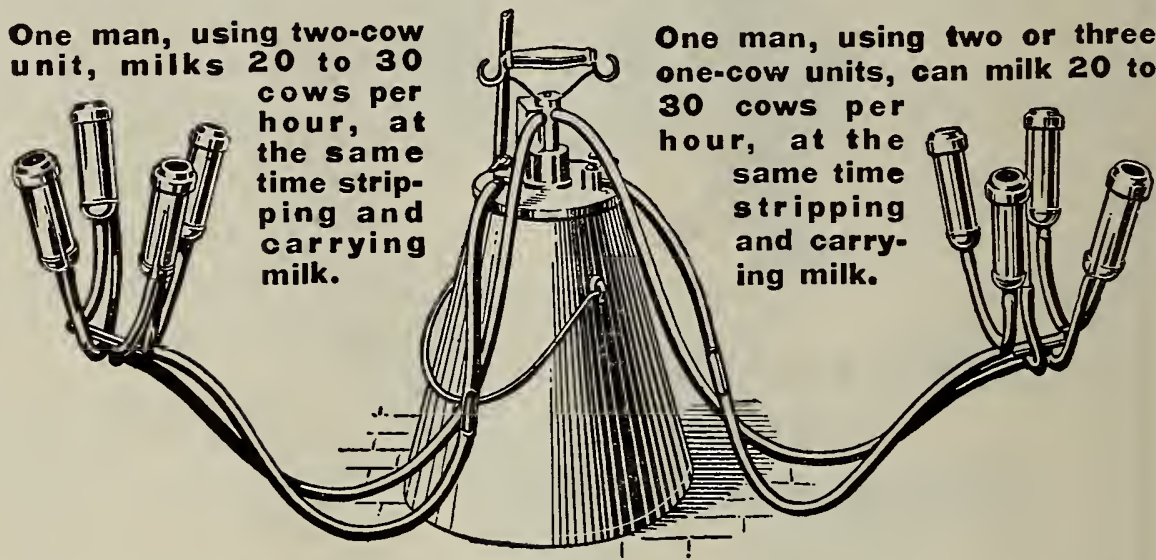

All metal parts, special non-corrosive nickel, the same color and composition all through. Teat cups universal---fit all teats.

All parts interchanqeab!e, accessible. easily cleaned and thoroughly sanitary.

\section{Royal Calf Food}

For Feeding Young Animals

This food is the result of extensive experiment and intelligent mixture of Protein, Fat and Gluten. Price, $25 \mathrm{lb}$. pail, $\$ 5.00 ; 13 \mathrm{lb}$. pail, $\$ 3.00$.

Write for Special Catalogue.

\section{The Hayden Sanitary Milking Stool}

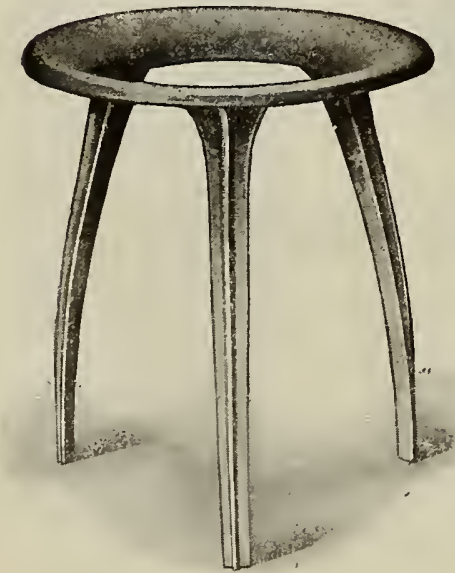

This Milking Stool is of galvanized iron, sanitary, strong, light and durablelasts a life time. Made to $\mathrm{d}$ isplace the filthy, wooden stool in the modern tie-up.

Price $\$ 1.25$

\section{WELLS, RICHARDSON \& CO.'S BUTTER COLOR}

Purely Vegetable. Always gives satisfaction. Small size $4 \mathrm{oz}$. $\quad 25 \mathrm{c}$ Medium size $10 \mathrm{oz} . \quad$. $\quad . \quad$. $50 \mathrm{c}$. Large size $24 \mathrm{oz} . \quad$. $\quad . \quad$. $\$ 1.00$ Cans, 1 gal. . . . . . . 2.50

\section{The Pilling Milk Fever Outfit}

For Air Treatment

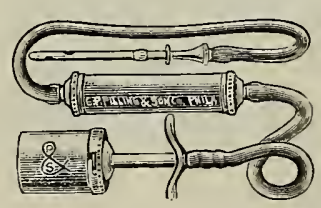

This treatment recommended by the Bureau of Animal Industry, United States Government, Department of Agriculture.

Price $\$ 3.00$ postpaid.

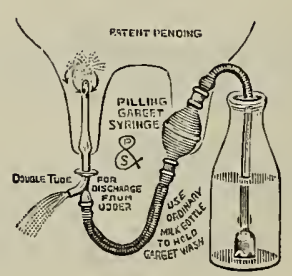

\section{Pilling Garget Outfit} Made on scientific principles.

The only proper and successful treatment of garget.

Price $\$ 3.00$ postpaid. 


\section{TO MODERNIZE YOUR FARM $===$ LOUDENIZE YOUR BARN}

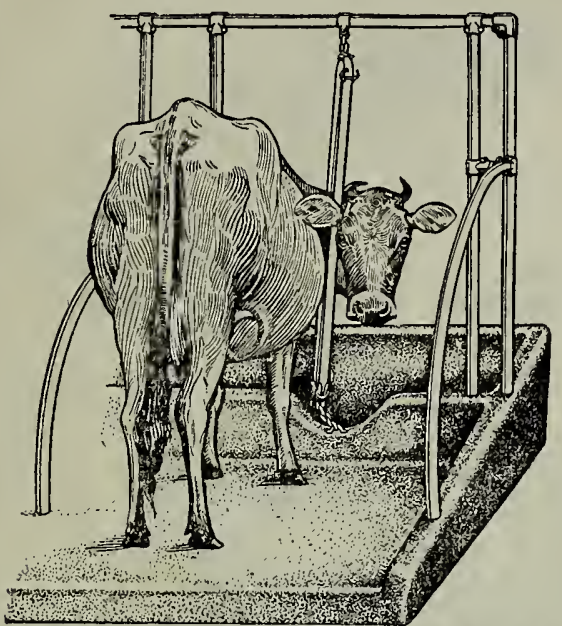

The Louden Steel Stall gives the cow the ame comfort and freedom of movement she would have in the field.

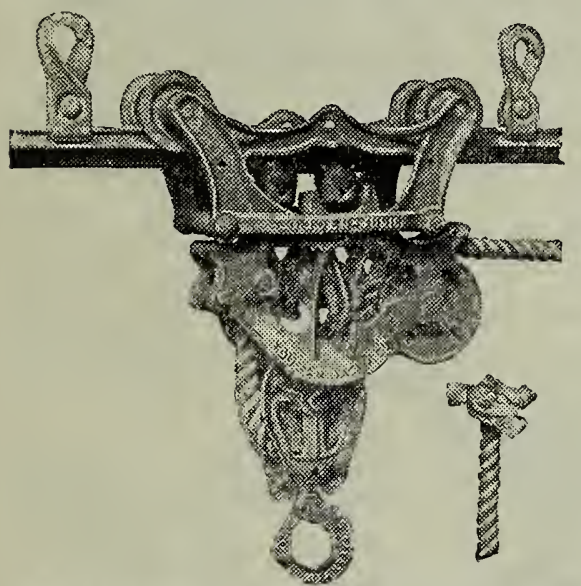

For fifty years Louden Hay Tools have been the world's standard for strength, simplicity and efficiency.

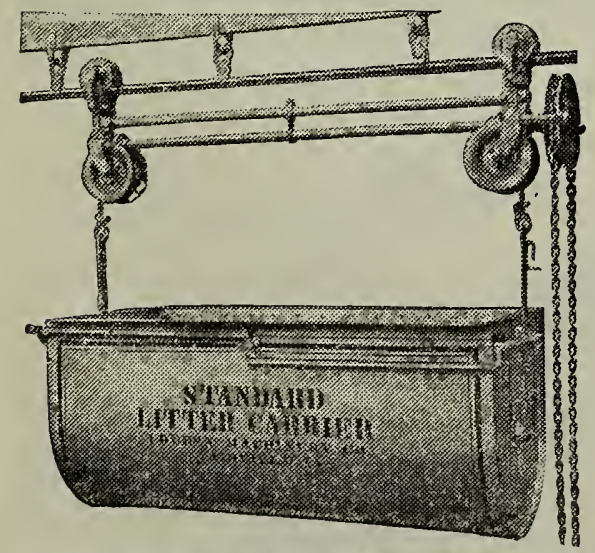

Your time is too valuable to be spent pushing a wheelbarrow. A Louden Overhead Litter Carrier solves the problem.

\section{We Can Fit Up Your Barn Complete With Louden Modern, Sanitary Equipment}

Louden equipment makes possible a clean, sanitary barn with a minimum of expense for upkeep.

When cows are transferred from dark, insanitary shelters to light, well ventilated, well equipped barns of the Louden type the milk flow invariably increases from 10 to 25 per cent., and the labor of caring for the herd is reduced by one-third or one-half.

The cost of installing Louden equipment is surprisingly small, and it is just as great an economy for the man with half a dozen head of cows as for the man who has to care for hundreds of animals. The percentage of labor saved is the same, and in either case it is 100 per cent. profitable.

We are prepared to quote you attractive prices on everything for your barn. The items illustrated are only a few products of the largest and most complete line of barn equipment made. Some of these products we carry in stock; others we can secure for you promptly.

\section{Going to Build or Remodel a Barn?}

If so we shall be glad to secure for you, free of cost to yourself, a copy of Louden's $\$ 1.00$ book of barn plans. It's the most valuable collection of practical plans and dollar-saving building information ever published. Contains more than 50 plans, with complete description and estimated cost of construction.

It is yours for the asking. 。

See us or write us in regard to your barn problems. We shall be glad to assist you, and to quote you lowest prices on your complete equipment.

\section{THE LOUDEN}

\section{LINE INGLUDES}

Hay Tools

Stalls and Stanchions

Steel Pens

Litter Carriers

Feed Carriers

Feed Trucks

Door Hangers

Horse Barn Equipment

Cupolas and Ventilators

Water Bowls

Specialities

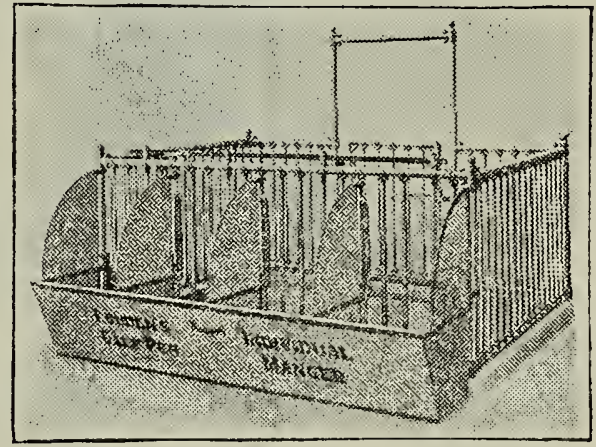

Louden Sanitary Steel Pens are made for cows, calves, bulls, sheep and hogs.

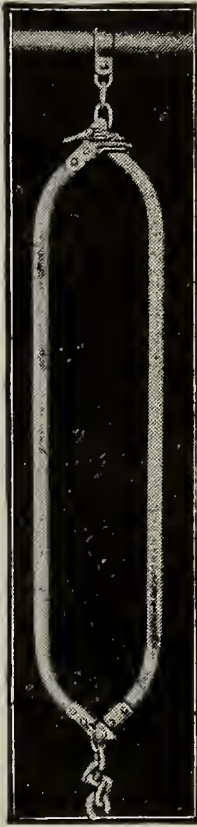

The Louden Tubular Steol Stanchion is the strongest, most comfortable cow tie made. 


\section{For Dairies, Creameries, Etc.}

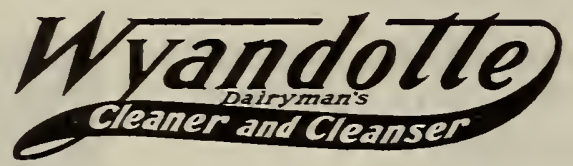

For cleaning vats, pasteurizers, strainers, cans, pipes, separators, and other articles in your plant that have become gummy or tainted with stale odors by the use of soap, soap porrder, or some similar washing compound, there is nothing that expense as Wyandotte Dairyman's Cleaner and Cleanser. A daily washing of the dairy or factory equipment will keep everything sweet and clean!

As you may already know, Wyandotte Dairyman's Cleaner and Cleanser is used by four out of every five butter and cheesemakers and by thousands of milk producers. It is the only cleaner recommended by State Dairy College Authorities. IVe know you will not be without it once you give it a thorough trial, and know what it does, and how little it costs to use.

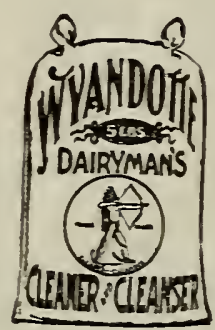

\section{Price, F. O. B. Portland}

Barrels (bulk) 280 lbs. per lb. . \$ 0.04 Kegs “ 80 “"

Barrels (50-5 lb. sacks) “" bbl. $5 \mathrm{lb}$. sack accomplishes this task so easily, and at such little

As a deodorizer and cleaner of everything about the hotel or home it is unsurpassed. We guarantee every claim and you assume no risks or fear of disappointment when you use Wyandotte Sanitary Cleaner and Cleanser.

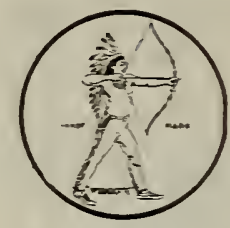

\section{Price List, F. O. B. Portland}

Barrels (bulk) $280 \mathrm{lbs}$. per lb. . \$0.04 Kegs " 80 " " . . . . . . . . . $5 \mathrm{lb}$. sacks " sack. . . 30

\section{Wyandotte Detergent}

\section{can be used to advantage in cases where a combined abrasive and cleaner are needed}

Wyandotte Detergent can be used to advantage in cases where a combined abrasive and cleaner are needed.

Wyandotte Detergent is quite different in its nature from the "Wyandotte" Dairy or Sanitary Cleaner. It contains a fine, flaky grit which makes it an abrasive and scourer. It also has the freshening and sweetening properties of the other "Wyandotte" products.

For cleaning marble, tile, painted walls, and other similar surfaces Tyandotte Detergent is unsurpassed. It scours clean, but does not scratch, mar or dull.

Rusty ice cream cans are easily scoured clean with Wyandotte Detergent, and although Wyandotte Detergent is not a metal polisher, for cleaning corroded iron and brass pipes, railings, dirty sinks, urinals, cuspidors and the like it has no equal.

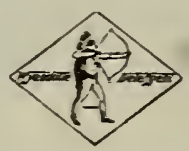

\section{Hotels and Restaurants}

Tyandotte Sanitary Cleaner and Cleanser when used for dish washing not only makes the dishes cleaner and brighter than is possible where soap is used, but it also makes the work easier. The same is true in the home.

Drain pipes, sinks, refrigerators, etc., are always kept free and open when Wyandotte Sanitary Cleaner and Cleanser is used.

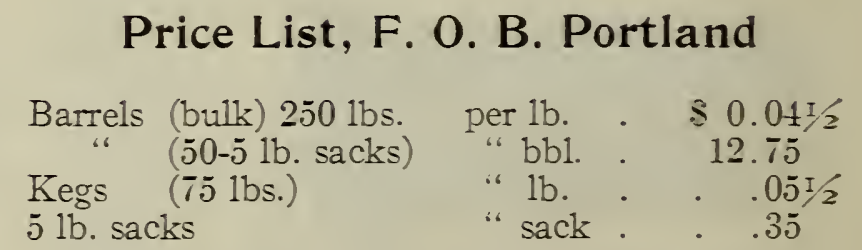

All prices subject to change without notice. 


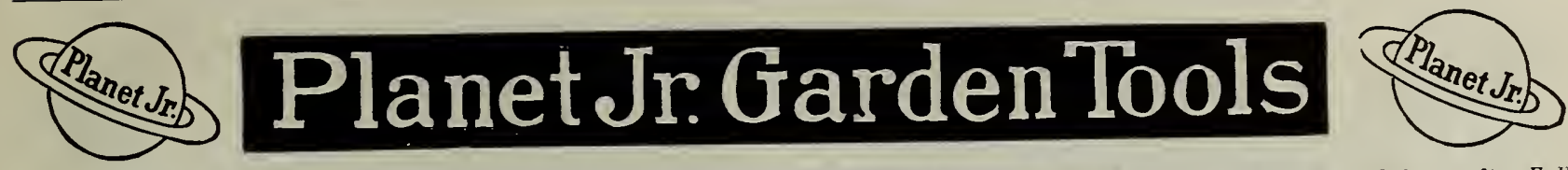

The "Planet Jr." Catalogue is the best and most instructive book ever issued on a similar subject. Full of little points that bring profit. Full of true and handsome illustrations. We mail it free to any address $(m$ application.

No. 4 Planet Jr. Combined Hill and Drill Seeder, Wheel Hoe, Cultivator and Plow

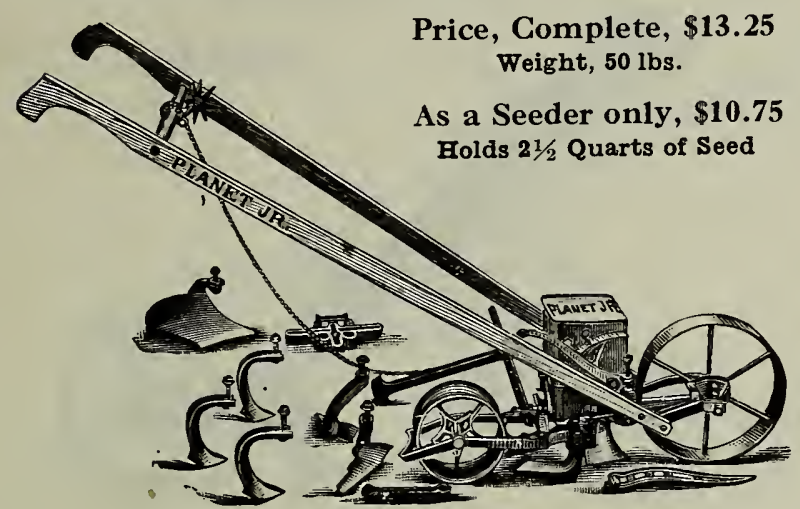

For use as a cultivator, the drill parts are removed and the tool frame substituted by changing but one bolt; it is then a perfect single wheel hoe, with a variety of tools.

No. 31 Planet Jr. Combined Drill Seeder and Single Wheel Hoe

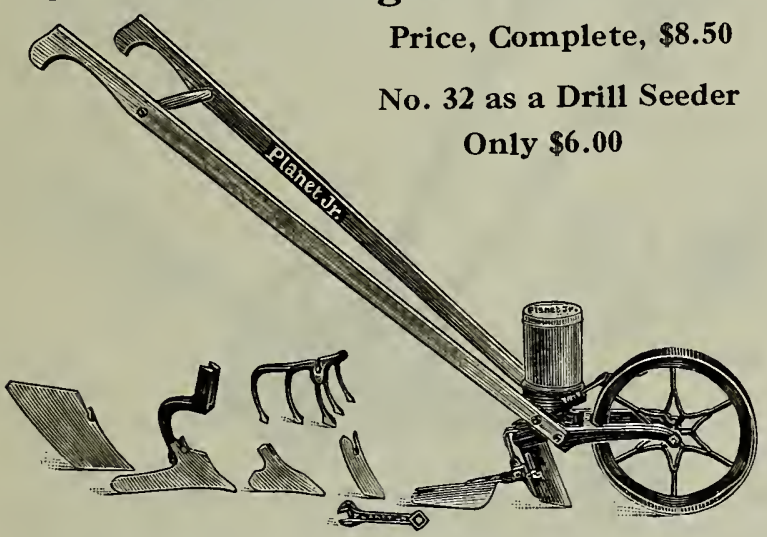

This new tool is of great value to gardeners who have never felt able to own either a seed drill or a wheel hoe. It will sow even a small packet of garden seed with great precision. Quickly changed to a splendid wheel hoe. A special machine for the small gardener.

\section{No. 3 Planet Jr. Hill and Drill Seeder}

Price, $\$ 12.50$

Holds 3 Quarts of Seed

A favorite among onion growers, market gardeners and seedsmen.

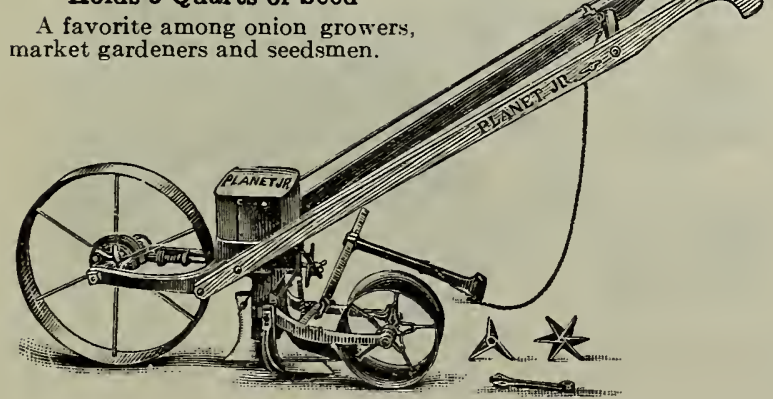

No. 25 Planet Jr. Combined Hill and Drill Seeder, Double Wheel Hoe, Cultivator and_Plow

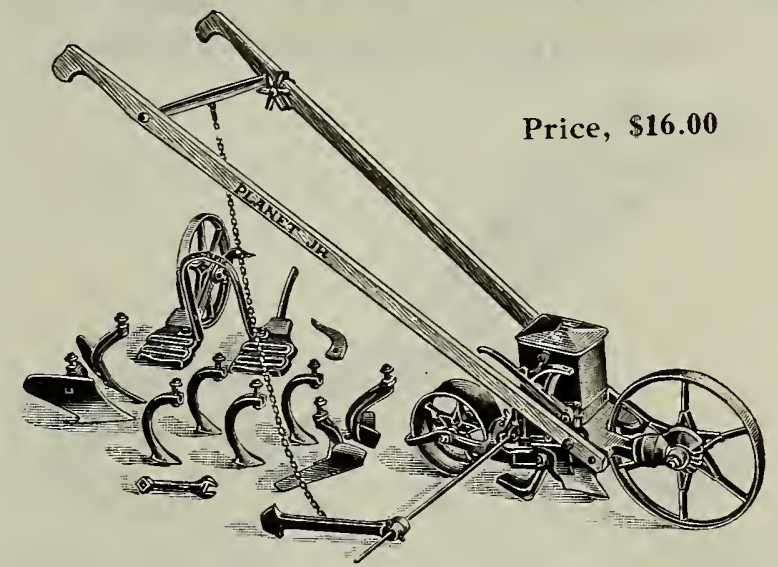

A splendid combination for the family garden, onion grower, or large gardener. It is a perfect seeder, and combined double and single wheel hoe.

No. 28 Planet Jr. Combined Hill and Drill Seeder,

Wheel Hoe Cultivator, Rake and Plow

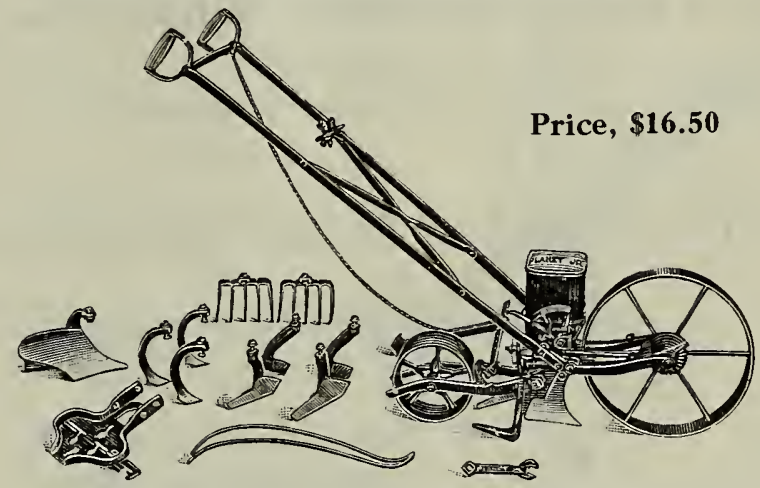

No. 28 is the best and most complete combined hill and drill seeder and single wheel hoe.

No. 12 Planet Jr. Double and Single Wheel Hoe

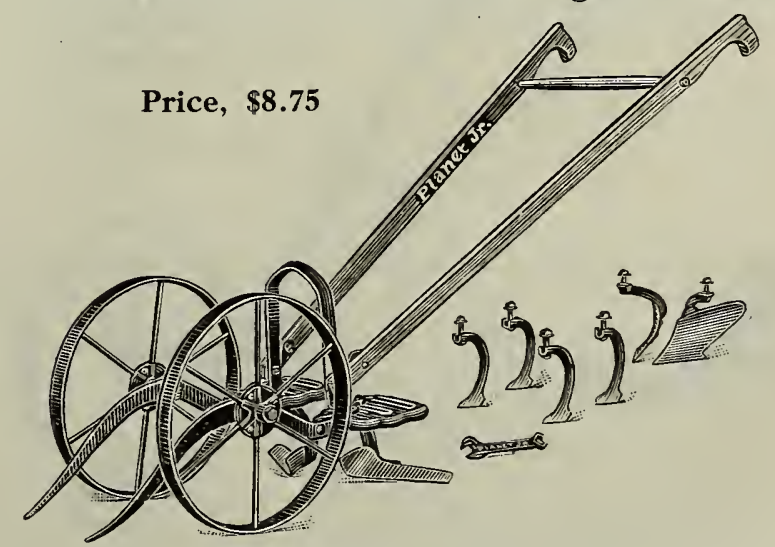

A single and double wheel hoe in one. Straddles crops till 20 inches high, then works between. Has steel frames and 14-inch steel wheels. 
60

Allen, Sterling \& Lothrop, Portland, Maine

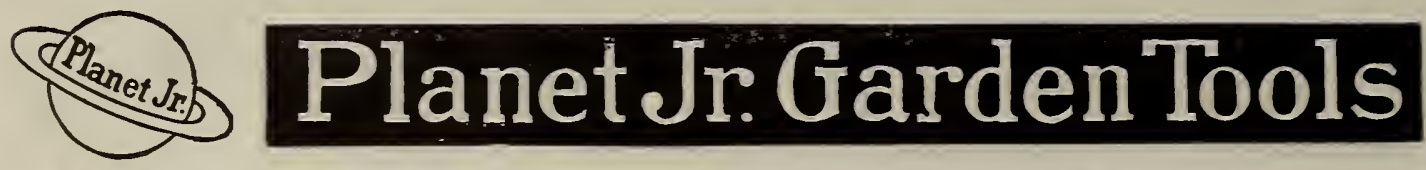

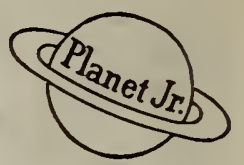

We offer these Tools as the highest type of their class. They have a great variety of attachments which adapt the implements to a large variety of work, and there is scarcely any garden culture of which they are not capable.

No. 16 Planet Jr. Single Wheel Hoe, No. 30 Planet Jr. Single Wheel Hoe, Cultivator, Rake and Plow Cultivator, Plow, Rake and Marker

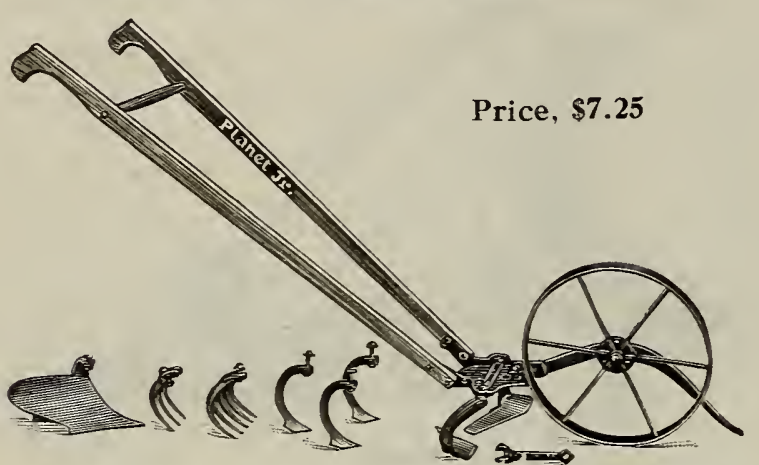

The highest type of Single Wheel Hoe made. Light, but strong, and can be used by man, woman or boy. Will do all the cultivation in your garden in the easiest, quickest, and best way.

Nos. 16,17 , and $171 / 2$ wheels, frames and handles are alike, but the attachments sold with each vary.

No. 17 Planet Jr. Single Wheel Hoe Price, $\$ 6.25$.

The No. 17 has a pair of 6 -inch hoes, a plow and a set of cultivator teeth.

No. 17 I $/ 2$ Planet Jr. Single Wheel Hoe Price, \$5.50

The pair of 6 -inch hoes, three cultivator teeth and leaf lifter which go with it, are all the finest of their kind.

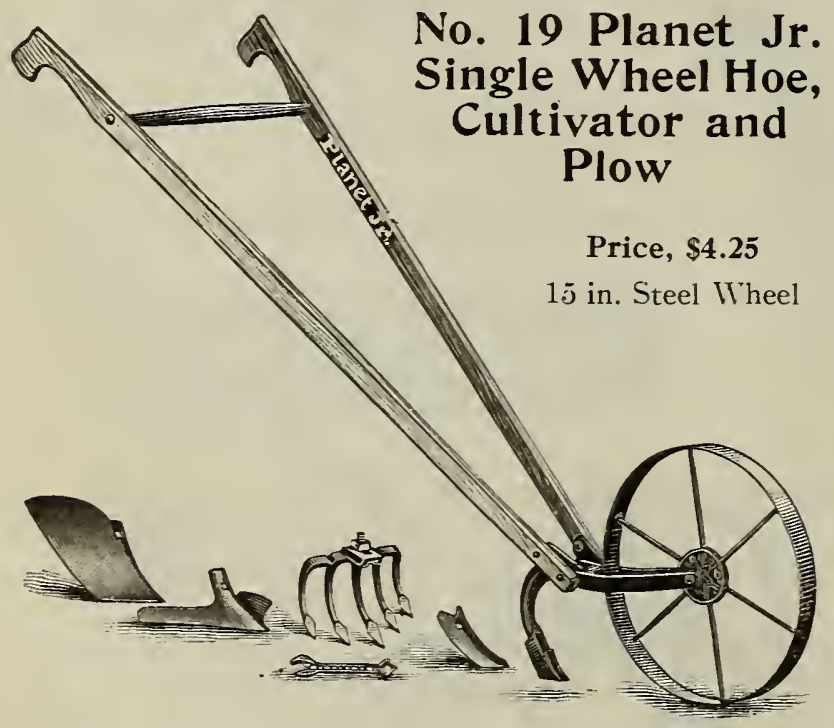

This attractive implement is especially designed for the farmer's garden work, though it offers to every one with either field or garden a cheap and effective tool for wheel-hoe operations. The high wheel makes easy pruning.

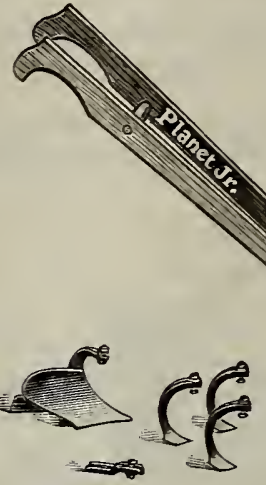

Price, \$7.50

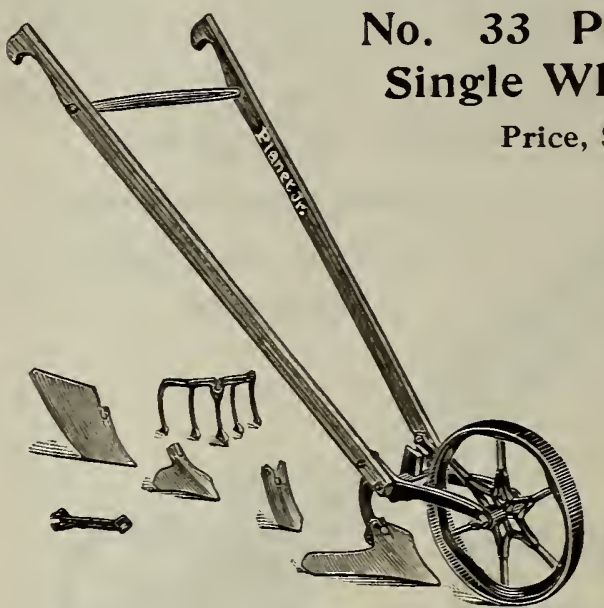

This combination will delight the suburbanite, the growing boy, women, younger or older, who will find it a light running wheel hoe that will save them hard work and help much to supply the table with fine vegetables.

No. 10 Planet Jr. Combination Farm and Garden Horse Hoe, Cultivator, Furrower, Plow and Vine Turner

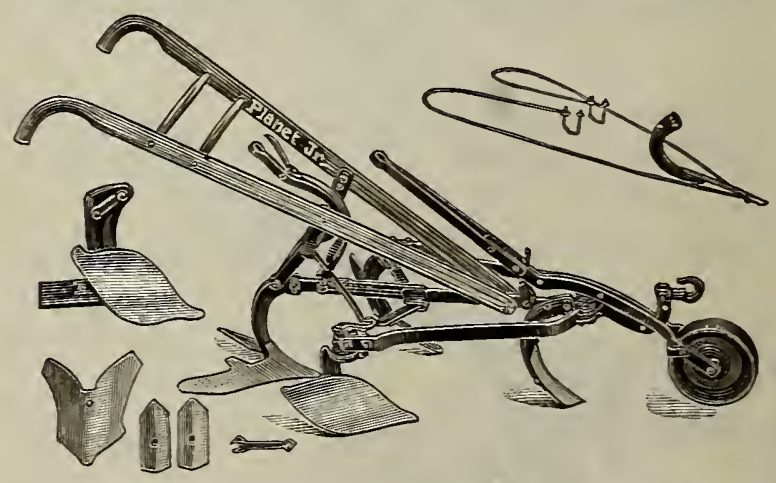

Price, complete, as in cut, $\$ 15.00$. Less Vine Turner, $\$ \mathbf{1 3 . 5 0}$. This implement is one of the best of Planet Jr. one-horse tools. 


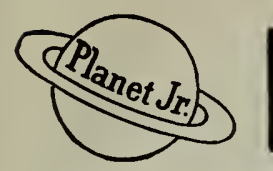

\section{Planet Jr. GardenTools}

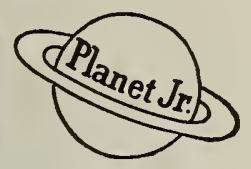

\section{No. 8 Planet Jr. Combined Horse Hoe and Cultivator}

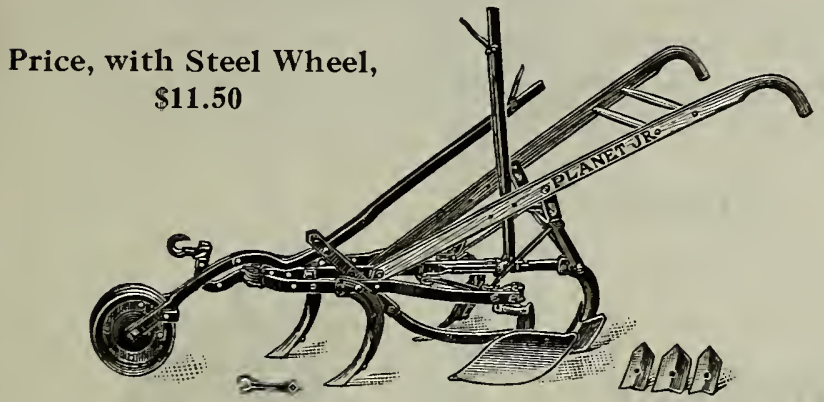

Equipment: Four $3 \times 8$-in. plates, one $4 \times 8$-in. plate, two 6 -in. side hoes, one 7 -in. shovel, lever wheel, lever expander. Depth regulator.

This is a general favorite, being easily understood and operated. The tool is especially strong, being braced so as to make a stiff, unyielding tool intended for long service.

\section{No. 9 Planet Jr. Combined Horse Hoe} Price, with Steel Wheel, $\$ 10.00$.

This Horse Hoe is identical with No. 8, except that it has no depth regulator and a plain wheel instead of lever wheel.

No. 9 Planet Jr. Plain Cultivator

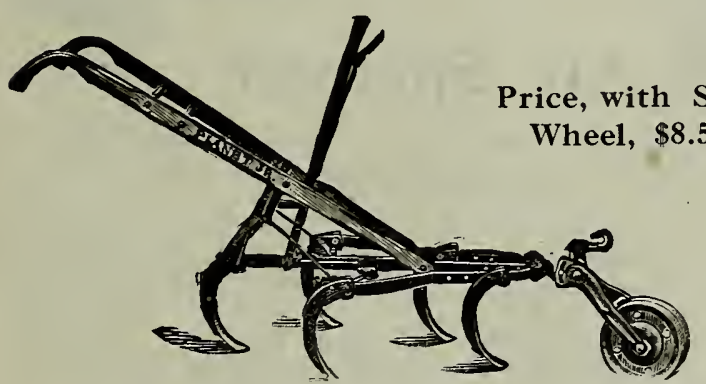

A light and strong tool, having improved patent hollow steel standards, parallel and extra high steel frame, patent lever expanders, handle braces and side adjustments for handles. Used with or without a wheel, the wheel being preferred.

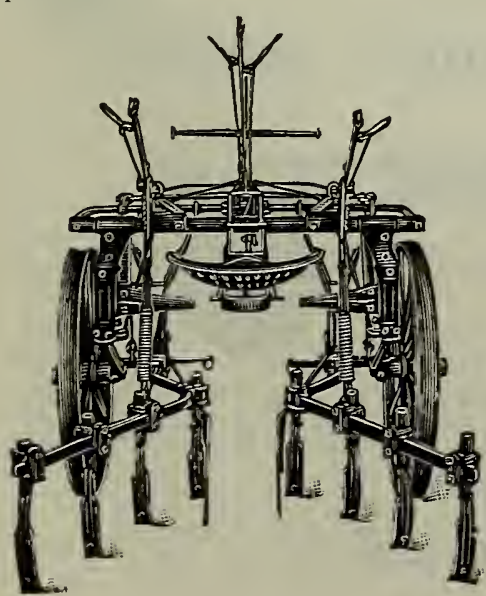

Price (fitted with spring-trip standards) $\$ 56.00$

Weight, $531 \mathrm{lbs}$

\section{No. 103 Planet Jr. Horse Hoe and Cultivator}

Price, $\$ 8.25$

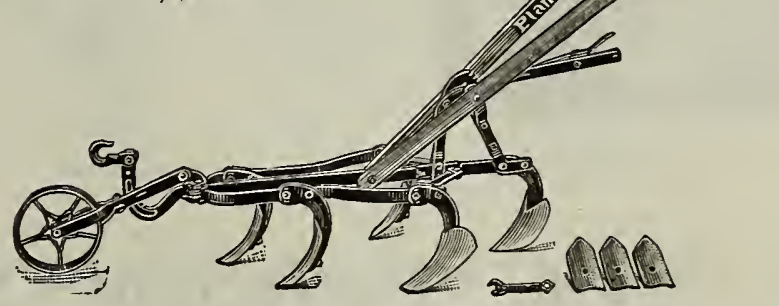

The Lever, instead of standing perpendicular, slants backward between the handles, free from danger of being bent or broken, and prevents injury to crops under cultivation. While the design is one of simplicity, it is very strong and most accurate in its work.

\section{No. 91 Planet Jr. Twelve-Tooth Harrow}

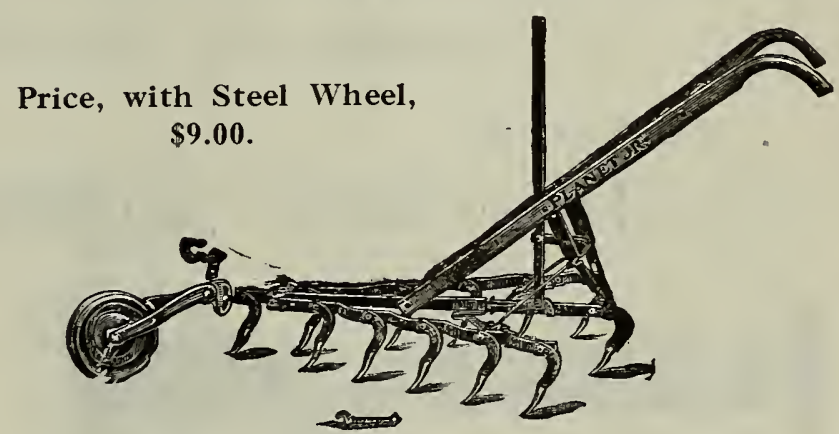

Gardeners cultivate better than formerly. It has been found to pay best. With the Twelve-Tooth Harrow you go as deep or shallow as you like, come up close to row without injuring plants, cut out all the weeds, stir the soil and mellow and fine it as with a garden rake. You widen and narrow as you please between 12 and 32 inches. It's a special favorite with strawberry growers, market gardeners and truckers.

\section{No. 76G Planet Jr. Pivot Wheel Riding Cultivator}

TheNo.76 G combines nearly all the advantages of other Planet Jr. riding cultivators. The combination of the best parts of these tools in one would seem to make a machine which would be without a rival in popularity and usefulness. The arch is high, frame and tongue are of steel and the change in width of the wheels is all that could be desired. It has powerful levers, and the gang frame is strong. The standards are adjustable for depth, and to throw to or from the row. The extra wide arch is very desirable. The draft is arranged to insure satisfactory work in all conditions of soil. 


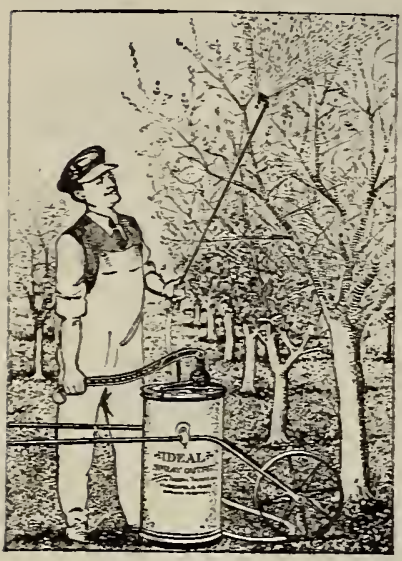

\section{“Ideal” Spray Outfit}

This outfit is light, compact and easy to operate. The tank holds fifteen gallons, is mounted so that the liquid will not slop or spill, and in a way that makes it easy to handle. The pump spreads across the top of the tank and is held firmly in place by a thumb nut. It has the largest air chamber of any spray pump of corresponding size. This enables the operator to keep a uniform pressure at the nozzle.

The pump cylinder is $1 \frac{3}{4}$ in. in diameter, 7 in. in length. The plunger is made of brass and is self-oiling. The packing is cotton wick, which will resist the action of the chemicals used for spraying and can be tightened without removing from the pump.

Each outfit has the following equipment: 10 feet $\frac{3}{8}$-inch 6-ply Pressure Hose; 8 feet Pipe Extension, in two pieces; 1 "Ideal" Nozzle; 1 Brass Shut-off Cock.

\section{Price, $\$ 17.00$}

\section{The "Perfection" Sprayer}

This is a Sprayer of high pressure type. It is larger, stronger and much more powerful than anything in its class.

For Spraying, Disinfecting or Whitewashing, on Plants, Bushes, Vines, etc. Pump has bronze ball valve, and is fastened to top of tank with heavy threads. Tank $7 \frac{1}{2}$ in. by 20 in., lock seamed with twenty-six rivets. Hose attached with clamps. All furnished with automatic shut-off nozzles which will handle whitewash and thin liquids without change of parts.

Galvanized Steel, \$5.50. Brass, \$7.50.

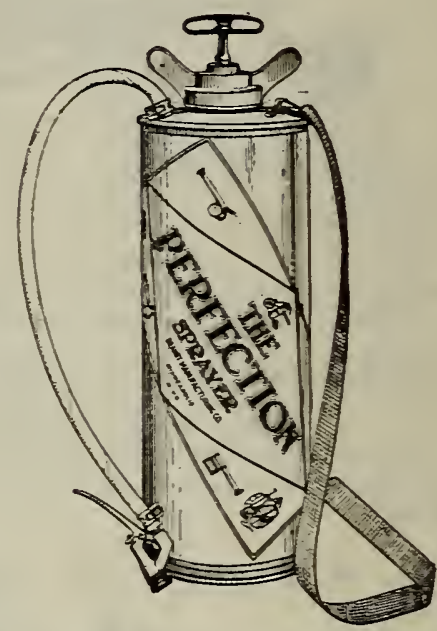

\section{The "Easy" Compressed Air Sprayer}

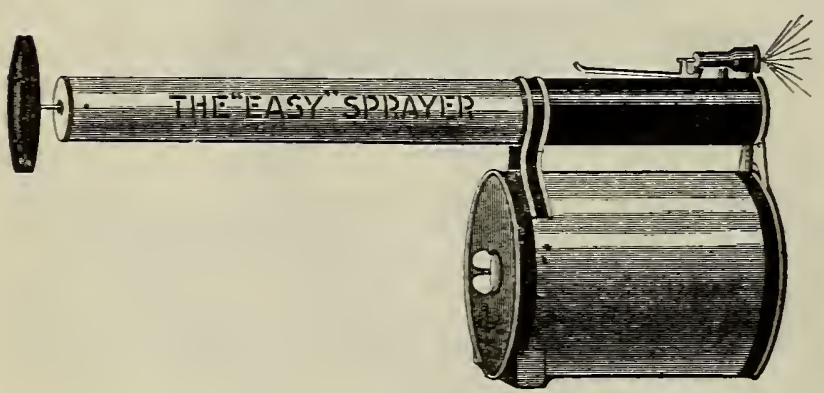

The only one of its kind on the market. Strong and durable.

Has a large and strong pump, automatic shutoff nozzle, legs under tank. Can be used for whitewashing, disinfecting and cleaning chicken houses, and is very desirable for large gardens, etc. It is made of galvanized steel. Holds one gallon.

Price, $\$ 1.75$

\section{The "MIDGET" Sprayer}

\section{The "NEW MISTY" Sprayer}

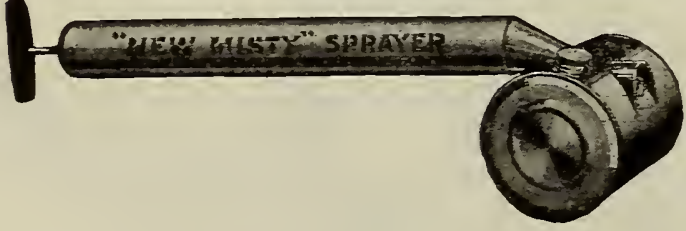

A general purpose Sprayer, for farm, stable or garden uses. Handles fly-oils, bug poisons and disinfectants. Made of heary tin. Holds one quart.

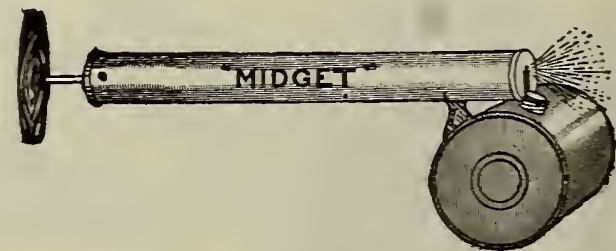

A small Sprayer for house use. Will handle disinfectants, bug poisons, etc., etc. Made of heavy tin. Holds one pint.

Price, 25c 


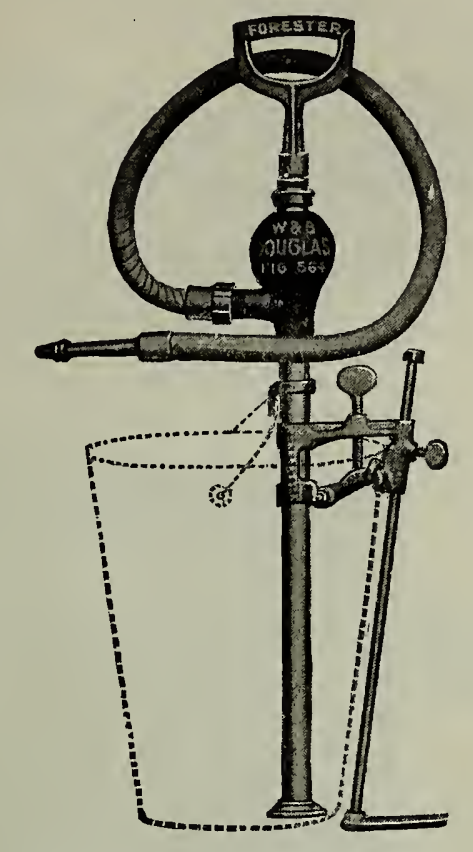

THE “FORESTER"

This pump is equipped with three feet of hose. One straight discharge tip and one rose sprinkler for garden use.

$$
\text { Price, } \$ 5.50
$$

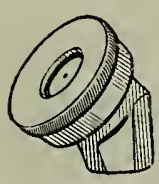

No. 66

\section{FOG NOZZLES}

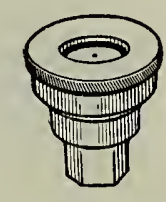

No. 68
Has removable discs, large openings and will not clog under any condition of liquid. Made in two forms, one for throwing the spray straight away, and one for throwing it at an angle. Fits $\frac{1}{4}$-inch pipe.

No. 66 or No. 68 , price each

$75 c$.

\section{PERFECTION NOZZLE}

Fits all makes of compressed air sprayers. Is automatic in action, very simple, and makes a wide coneshaped spray of finely beaded mist. Will handle whitewash or throw a straight strean without change of parts.

Price

$\$ 1.15$

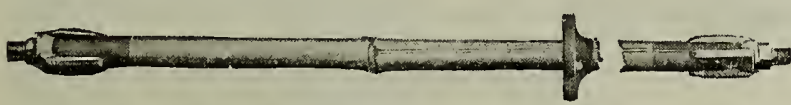

Bamboo brass lined spray poles, 8,10 , or $12-\mathrm{ft}$. long. The inner tube is all in one piece, locked to the pole at both ends and will not turn inside of the bamboo. It is fitted with adjustable drip shield and is furnished either with or without stop cock. Note the end castings.

No. 42, price complete with cock, 8-ft.

No. 43 , price complete with cock, $10-\mathrm{ft}$.

3.75

No. 44, price complete with cock, 12-ft.

\section{"MODOC" BUCKET PUMP}

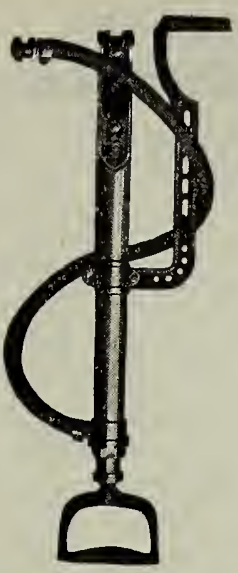

This pump has features and qualities never shown before or found in a bucket pump.

The cylinder is very large and is made of heavy seamless brass tubing. The plunger is hollow, thus forming an air chamber which insures a steady flow of liquid. The pump is equipped with 3 feet $1 / 2$-inch spray hose attached with clamps.

Price, $\$ 3.50$

\section{DICKEY BUG DEATH DUSTER}

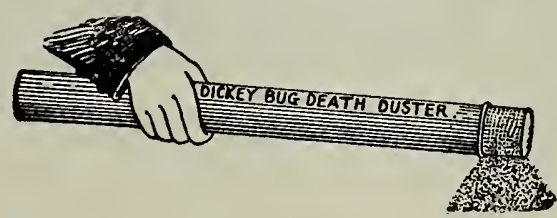

For use in applying BUG DEATH, DRY, to small flower or vegetable gardens.

Price, 25c

\section{FOR FARM USE}

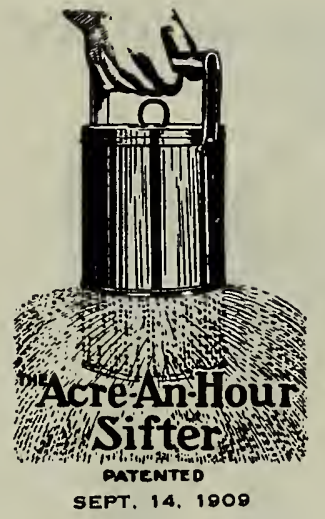

Is ideal for applying BUG DEATH DRY.

It is the very latest, a remarkably effective and distinctly economical method. Easy to operate and gives quick covering to all plants and vines requiring a top aplication.

Price, 60c.

\section{FIRE-FLY GARDEN PLOW}

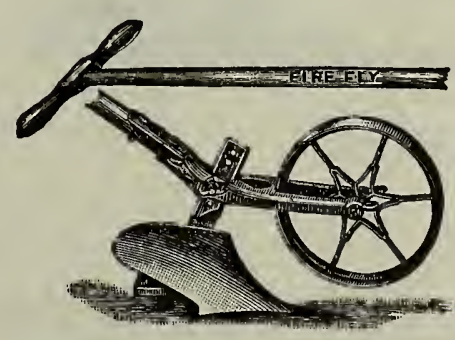

This tool is exceedingly useful to owners of small gardens. It will throw a furrow four to six inches wide and one to three inches deep, and deeper by going a second time in each furrow. Chicken raisers find it of great advantage in plowing up their scratching yards.

Price, $\$ 2.75$ 


\section{The Skinner System of Irrigation}

There are times in nearly every growing season when a crop could be saved or its value doubled if the grower could call down from the skies a soft, gentle rain of sufficient duration to abundantly water the crop. With the Skinner System of Irrigation the rainfall is at the command of the grower.

Not only will the Skinner System protect, against drought but it will distribute the water with a uniformity not otherwise possible. The moisture is applied in the way which is most advantageous to the soil and to the crop, without injury to the plant. Commercial fertilizers, insectides and fungicides can be distributed through the Skinner System. All of this is accomplished with a miminum of labor. The early maturity of the crop, securing the advantage of better prices, and the more luxuriant and uniformly developed growth mean greater returns per acre.

\section{Prices on Application}

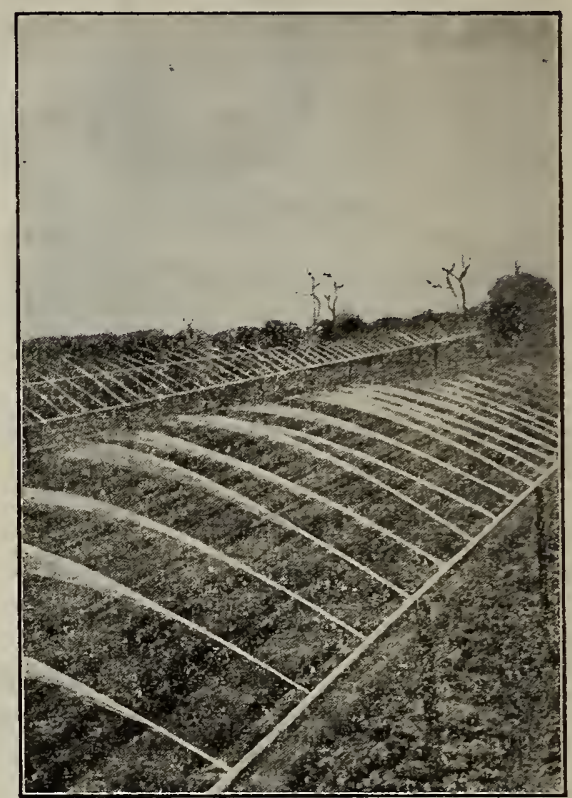

\section{Nonesuch Lever Cutter}

A simple and d u rable machine. The devicefor adjusting the lever, being removed from the pivot, enables us to have a stationary pivot firmly attached to the machine, and consequently not $1 \mathrm{iab} 1 \mathrm{e}$ to get loose, as in all machines where the pivot is adjustable.

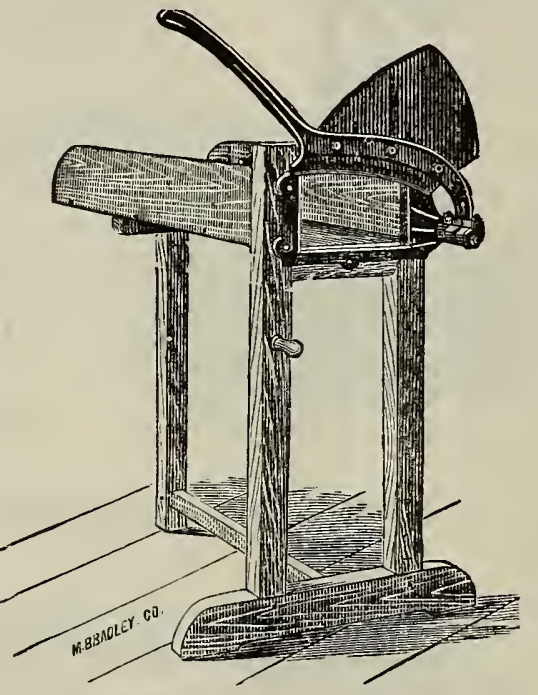

Price $\$ 4.50$
We Carry in Stock the Best Grades of Brushes for Cleaning

MILK BOTTLES, TEST BOTTLES, MILL CANS AND CREAM SEPARATORS

BUTTER LADLES

BUTTER SPADES

BUTTER BOWLS

ACID MEASURES

GRADUATING GLASSES MILK PIPETTES

SEPARATOR OIL 


\section{INSECTICIDES AND FUNGICIDES}

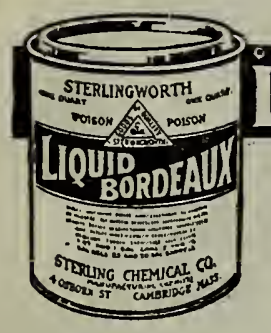

Prices: 1 qt. cans $40 \mathrm{c}$. each, mailing weight 4 lbs.; 1 gal. cans $\$ 1.25$ each, mailing weight 13 lbs.; 5 gal. kegs $\$ 4.50$; 10 gal. kegs $\$ 8.00$.

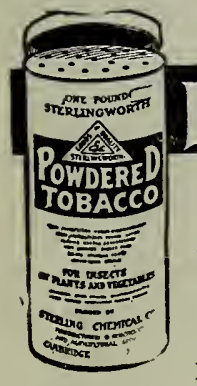

\section{POWDERED TOBACCO}

An effective and cheap remedy for many bugs, worms, lice and spiders on Cabbage, Squashes, Melons, Cucumbers, Potatoes, Plants, etc. It is for use while the vegetation is damp.

Prices: $1 \mathrm{lb}$. box 10c., mailing weight $2 \mathrm{lbs}$; 100 lb. sacks $\$ 3.50$ each. (Add 5 cents for packing when ordered by parcel post.)

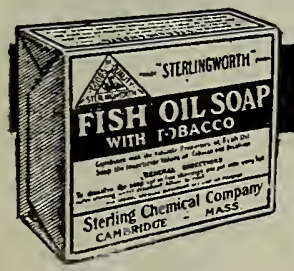

\section{FISH OIL SOAP}

It has the value of Fish or Whale Oil Soaps and the additional insect killing properties of tobacco. Useful against scale, plant lice, and all other sucking insects on trees, shrubs, plants, vines, etc. One pound makes 2 to 5 gallons of spray. Prices: $1 \mathrm{lb}$. box 20c., mailing weight 2 lbs.; 5 lb. box 70c., mailing weight $6 \mathrm{lbs}$; $10 \mathrm{lb}$. box $\$ 1.25$, mailing weight $11 \mathrm{lbs}$.

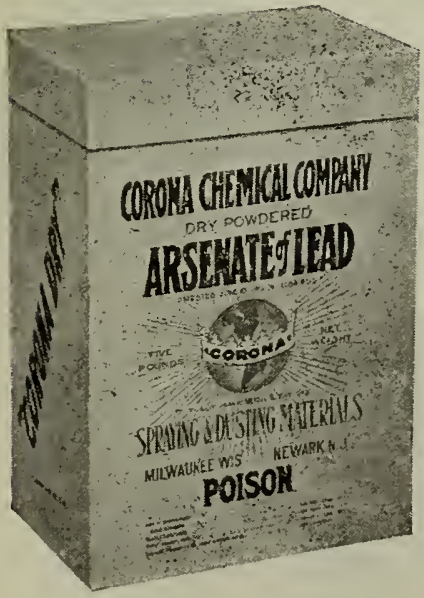
Portland.

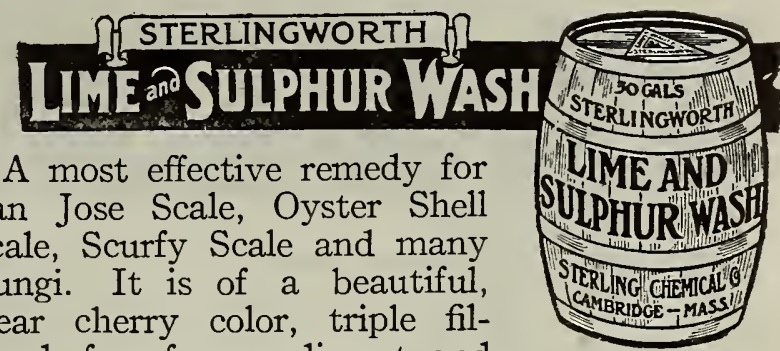
tered, free from sediment and will not clog the spraying apparatus. Sample mailed upon request. It is ready for use by adding cold water. No heating is necessary. Prices: 1 qt. cans $25 \mathrm{c}$., mailing weight 4 lbs.; 1 gallon cans 65c., mailing weight 13 lbs.; 5 gallon jacket cans $\$ 2.00$ each; 10 gallon jacket cans $\$ 3.50$ each; 25 gallon kegs $\$ 6.00$ each, 50 gallon bbls. $\$ 8.00$.

\section{ARSENATE OF LEAD}

For all leaf-eating insects.

Sterlingworth Arsenate of Lead has many advantages over many other arsenical preparations as ar. insecticide. Its chief advantages

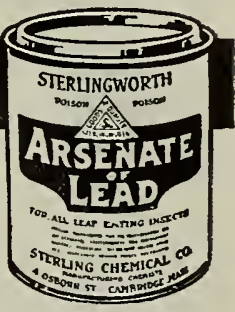
are its great adhesive power and its harmlessness to the foliage. Prices $1 \mathrm{lb} .20 \mathrm{c}$., mailing weight $2 \mathrm{lbs}$; $5 \mathrm{lbs}$. 90c., mailing weight 7 lbs.; 10 lbs. \$1.60, mailing weight 12 lbs.

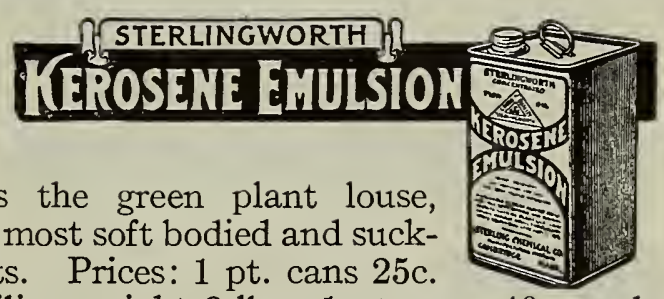

It kills the green plant louse, scale and most soft bodied and sucking insects. Prices: 1 pt. cans 25c. each, mailing weight 2 lbs.; 1 qt. cans $40 \mathrm{c}$. each, mailing weight 4 lbs.; 1 gallon cans $\$ 1.00$ each, mailing weight $11 \mathrm{lbs}$.

\section{"CORONA DRY"}

It has been demonstrated by large and practical usage that "Corona Dry" is the most successful Arsenate of Lead that has ever been produced.

It is the result of an extended period of investigation and research to obtain a powdered product superior to the old paste material and other dry Arsenates of Lead that are now on the market.

Mixes quickly and easily in water. There is no sediment, no lumps left over in the bottom, no waste. It will never clog the spray nozzle. I/2 lb. pkg. 25c. each, 1-lb. pkg. 40c., 5-lb. pkg. $\$ 1.85,10-1 b$. pkg. $\$ 3.50$, 25 -1b. drums $\$ 6.75$. 50-1b. drums $\$ 12.50,100-1 b$. drums $\$ 23.00$. Net f. o. b.

\section{BOWKER'S PYROX}

Kills all leaf-eating insects and prevents diseases. It serves the purposes for which two mixtures were previously used. It is a dense, heavy, yet creamy paste, is easily mixed with cold water, and sticks like paint to the foliage. Prices: 1 lb. 25c., 5 lbs. $\$ 1.00,10$ lbs. $\$ 1.75,25$ lbs. $\$ 4.00$, 50 lbs. $\$ 7.50,100$ lbs. $\$ 13.00$. 


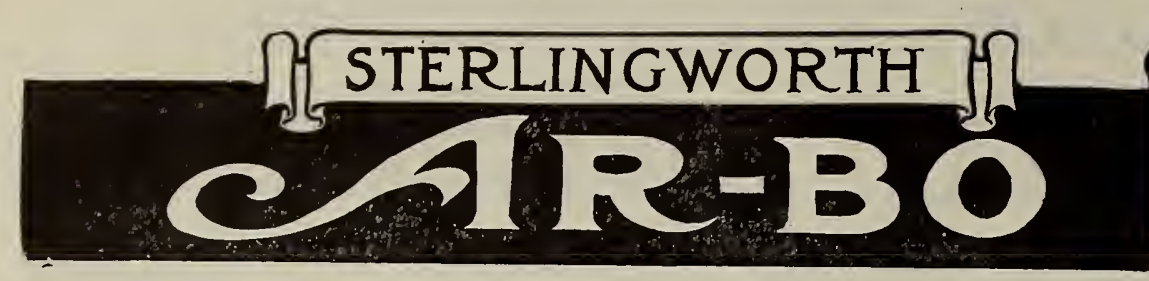

A practical and satisfactory all round spray. It kills leafeating insects, and prevents and remedies fungous diseases with one spraying. You kill two birds (fungi and bugs) with one stone by using this spray and get the stone back, for the increased crop pays for the material and labor. It sticks like glue. Used by mixing one pound to ten gallons of water. Prices: $11 \mathrm{~b} .25 \mathrm{c}$, , mailing weight 2 lbs.; 5 lbs. $\$ 1.00$, mailing weight 7 lbs.; 10 lbs. $\$ 1.75$, mailing weight $12 \mathrm{lbs}$; $25 \mathrm{lb}$. keg $\$ 4.00$, mailing weight $33 \mathrm{lbs}$.: 50 lb. kegs $\$ 7.50$ each; 100 lb. kegs $\$ 13.00$.

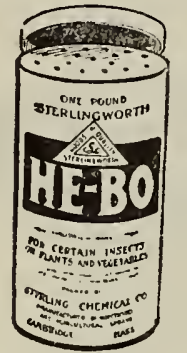
and many other leaf eating insects where a milder poison than Paris Green or Arsenate of Lead is desired.

Prices: $\frac{1}{2} 1 \mathrm{~b}$. box $15 \mathrm{c}$., mailing weight $1 \mathrm{lb} ; 1$ lb. box 25c, mailing weight 2 lbs. Add 5c. for packing to above prices if ordered by mail.

\section{STERLINGWORTH PLANT LICE KILLER}

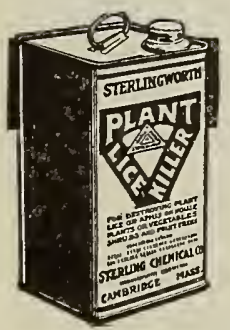

This is prepared exclusively for aphis or plant lice and spiders on house plants and vegetables. It is useful against most of the small sucking insects which infest house plants and greenhouse flowers. It is used by diluting one part of killer in fifteen parts of water, and may be applied by spraying or sprinkling.

Prices: Home size (one pint) 25c., mailing weight $3 \mathrm{lbs}$; greenhouse size (one gallon) $\$ 1.50$, mailing weight $11 \mathrm{lbs}$.

Aphine. The insecticide that kills aphis, green fly, thrip, red spider, etc. Full directions for use on each can. $1 / 4$ pt. can, $25 \mathrm{c}$., $1 / 2$ pt. $40 \mathrm{c}$., 1 pt. 65 c., 1 qt. $\$ 1.00,1$ gallon, $\$ 2.50$.

Nico-Fume Liquid. Used as a spray or as a vapor, Does not stain nor injure blooms, $1 / 4 \mathrm{lb}$. can 50 cts., 1 lb. can $\$ 1.50$,
"Black Leaf 40". Tobacco Extract is the strongest extract of tobacco made, being $40 \%$ pure nicotine.

Recommended for black Aphis and sucking insects of all kinds. Spraying directions on each package. $1 / 2 \mathrm{lb}$. cans $75 \mathrm{c}$. each, $2-1 \mathrm{~b}$ cans $\$ 2.50$ each, $10-1 b$. cans $\$ 10.75$ each.

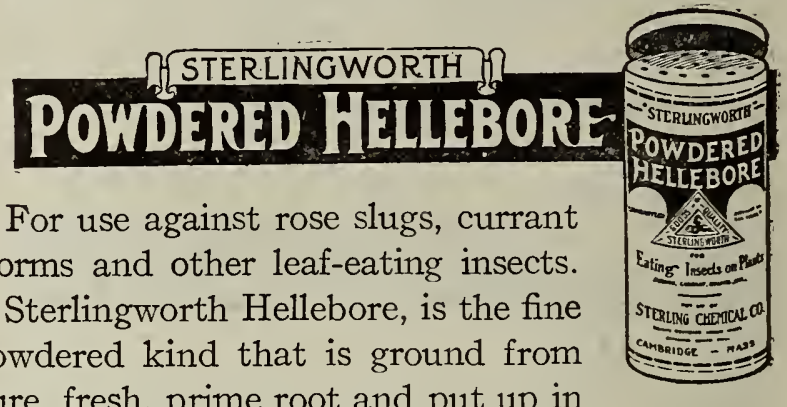
pure, fresh, prime root and put up in the round tight sifter-top box.

Price variable, owing to Euorpean conditions. Quotations upon application.

FOR SUBSTITUTE FOR HELLEBORE, SEE STERLINGWORTH HE-BO

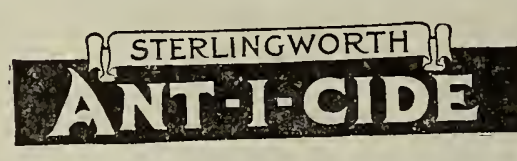

A powder for use against ants in lawns and gardens.

One pound covers about 200

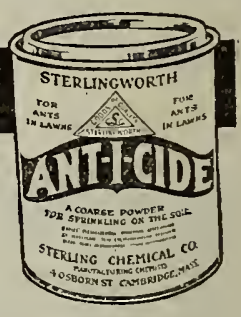
square feet. Prices: 1 lb. box 25c., Parcel Post weight 2 lbs., 5 lb. tins $\$ 1.00$, Parcel Post weight 6 lbs.

Paris Green. For potatoes, etc. Strictly pure. 1/2 1b. 25c., 1b. 35c. Subject to market changes.

Tobacco Dust. Stoothoff's "Fumigating Kind."

For burning. Lb. 10c., 5 lbs. 25c., 50 lbs.; $\$ 2.25,100$ lbs. $\$ 4.00$.

Tobacco Stems. For fumigating. Per $1 \mathrm{~b} .5 \mathrm{c}$., 5 lbs. 20c., 50-1b. sack, $\$ 1.50,100$ to $300 \mathrm{lbs}$. $\$ 2.00$ per 100 lbs. 
No long stories or big claims about this Fly Oil. We think it is the best one made. Buy a can. Use half of it. If you are not satisfied bring us the half-empty can and get your money back. Protects all day in ordinary weather. Flies hit by it are killed, others are kept off by the odor. Applied with a brush, rag or hand sprayer. It pays to protect. Prices: $1 \mathrm{qt}$. cans $25 \mathrm{c}$. each, mailing weight, 4 lbs., 1 gal. cans $75 \mathrm{c}$., each, mailing weight 11 lbs.

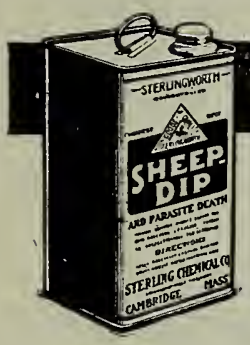

cattle and hogs.

\section{SHEZPTERLINGWORTH}

A standard article for preparing an effective and economical dip for ridding sheep of ticks, lice and scab, also kills certain fleas, lice and gnats on horses,

One gallon makes 56 gallons of strong dip by mixing with water.

Prices: 1 qt. 50c., Parcel Post weight 4 lbs., I/2 gal. 85c., Parcel Post weight 7 lbs., 1 gallon can $\$ 1.50$, Parcel Post weight 11 lbs.

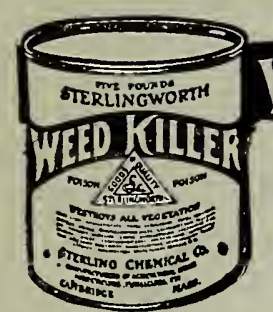

\section{STERLINGWORTH}

\section{WEED KILLER}

Kills weeds in walks, drives and tennis courts where no vegetation is wanted. A powder used by dissolving in water. $1 \mathrm{lb}$. makes 10 gallons. Prices, 1b. 50c., Parcel Post weight 2 lbs. 5 lb. pkg. $\$ 2.00$, Parcel Post weight $6 \mathrm{lbs}$

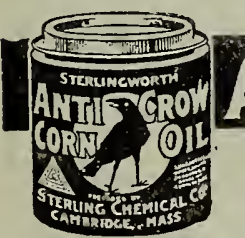
STIRELINGWORTIT: Giil Crow COR OIII

Protects newly planted corn from crows. Mix 1 part Anti Crow Corn Oil with 2 parts hot water. Prices: pt. 25c., Parcel Post weight 3 lbs., qt. 40c. Parcel Post weight 4 lbs., gal. $\$ 1.25$, Parcel Post weight 13 lbs.

\section{WARNCKE'S CUTWORM F.OOD}

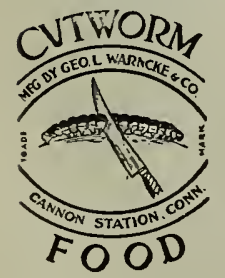

It consists of a material that is more delicious and is much more preferred by the cutworm than the plants themselves. It is sprinkled on the ground around the plant just as it is found in the package.

Prices: 1 lb. package, 25c., (by mail, 35c.); 5-1b. box, $\$ 1.00$.

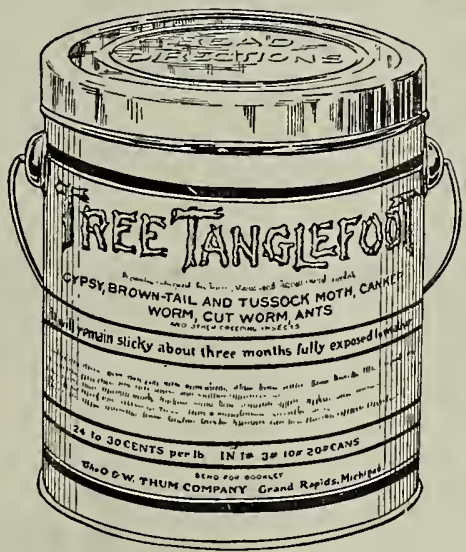

PRICES:

1-1b. can, 30c.; 3-1b. can, 85c.; 10-1b. can, $\$ 2.65 ; 20-1 b$ can $\$ 4.80$

\section{No $0=$ SCAB}

For preventing potato scab, oat, wheat and grain. Mixes one pound to fifteen gallons of water. Directions on label. Price: $1 \mathrm{lb}$., (1 pt.) $50 \mathrm{c}$.

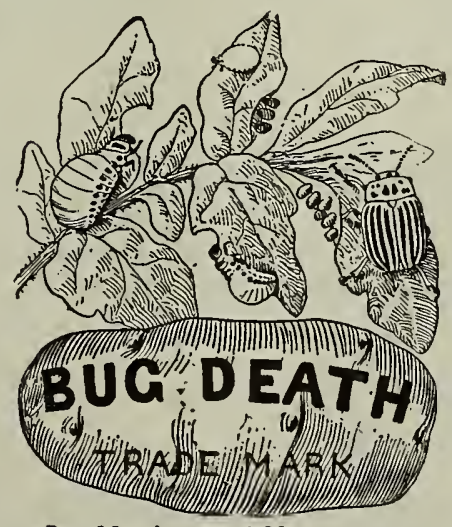

Pat. March 16 and Nov. 9, 189 i.
Bug Death is absolutely harmless to the life of the plant, and because this is so is just the reason it is so vastly superior to any other insect destroying preparation. Kills all bugs and worms that chew the leaves and foliage. Contains no Paris Green or Arsenic. May be used dry or in solution.

Prices: 1 lb. package, 15c., 3-lb. package, 40c. 5 -1b. package, 55c., 121/2-1b. package, $\$ 1.10,100$ lb. keg, $\$ 7.50$. 


\section{"SCALEC IDE"}

"SCALECIDE" is a mild, smooth, easily applied spray that will not clog your hose nor corrode your machinery. It keeps tree clean and healthy, and effectively takes care of the leaf roller, bud moth, case bearer, San Jose scale, and all kinds of scale. The fungicidal action of "SCALECIDE" will also check such deadly diseases as apple canker and collar rot, and it will also show an invigorating effect on tree growth.

"SCALECIDE" can be instantly prepared by simply adding 15 gallons of water to every gallon of the concentrated material. It will mix in almost any kind of water, but rain or soft water are best. "SCALECIDE" will not freeze before mixing with water, and you can apply it on any clear day when the thermometer is above 40 Fahrenheit, after the leaves begin to drop in the Fall, or until the buds begin to show green in the Spring.

Prices: 1 qt. can 35 c.; 1 gallon can, $\$ 1.00 ; 5$ gallon can, $\$ 3.25$. Special prices quoted on application for larger quantities.

\section{CARBOLA}

THE DISINFECTANT THAT PAINTS-Use It Instead of Whitewash.

A snow white cold water paint that will not blister, flake or peel off, combined with a germicide 20 times stronger than carbolic acid, but neither caustic nor poisonous.

Can be applied with a brush or sprayer.

Trial package, by parcel post .....30c.

Paints and disinfects 250 square feet. 10 pounds (10 gallons) . . . . . . \$1.00
20 pounds (10 gallons) . . . . $\$ 2.00$

50 pounds (50 gallons) . . . . . . 4.00

\section{BOWKER'S PLANTFOOD}

Made expressly for house plants, being entirely odorless. Small pkg., 15c., large pkg., 25c.

\section{CLAY'S FERTILIZERS IMPORTED}

Recommended to all who grow either fruit, flowers or vegetables. Should be used in potting soil.

Prices: $14-1$ b.: bag $\$ 1.25 ; 28-1 b$. bag $\$ 2.25$; $56-1 \mathrm{~b}$. bag $\$ 4.00$.

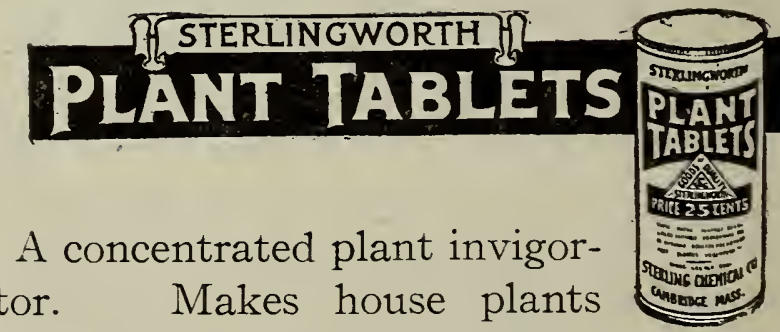

bloom luxuriantly. Dissolve in water and water soil. No odor. Clean, easily used. Prices: 10c., 25c., and 50c., postpaid. 


\section{AGENTS FOR \\ LISTER'S STANDARD FERTILIZERS}

A FERTILIZER FOR EVERY CROP AND DIFFERENT SOIL REQUIREMENTS

GUARANTEED ANALYSIS

Lister's Success

Lister's Corn and Potato -

Lister's High Grade Special - - -

Lister's Standard Super. of Lime - -

Lister's Potato Manure

Lister's Superior Ammoniated Superphosphate

Lister's Special Potato Fertilizer

WRITE US FOR QUOTATIONS

\begin{tabular}{|c|c|c|}
\hline Ammonia & Ava. P. A & \\
\hline $11 / 2$ & 10 & \\
\hline $2 \pi / 2$ & 8 & \\
\hline $21 / 2$ & 10 & \\
\hline 3 & 9 & \\
\hline 5 & 8 & \\
\hline 4 & 10 & \\
\hline 5 & 10 & \\
\hline
\end{tabular}

\section{Sheep's Head Brand Pulverized Sheep Manure}

A complete natural fertilizer, supplying all the necessary plant food elements-Nitrogen, Phosphoric Acid and Potash-in combination with organic matter or humus, and it is this natural combination that produces the peculiar action and effect in the soil which can only be had from animal manures. It can be used without fear of weeds and foreign grasses that always follow the application of ordinary stable manures.

Sheep manure is probably more largely used in greenhouse growing of flowers and vegetables for market than any other fertilizer, because it is safe, and can be relied upon for quick, sure results. It is unequalled for either dry or liquid top-dressing, especially for carnations, chrysanthemums, asters, and other hardy floral crops.

1 lb. 10c., 5 lbs. 25c., 10 lbs. 40c., 25. lbs. 75 c., 50 lbs. $\$ 1.25,100$ lbs. $\$ 2.00$.

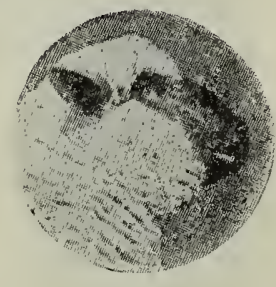

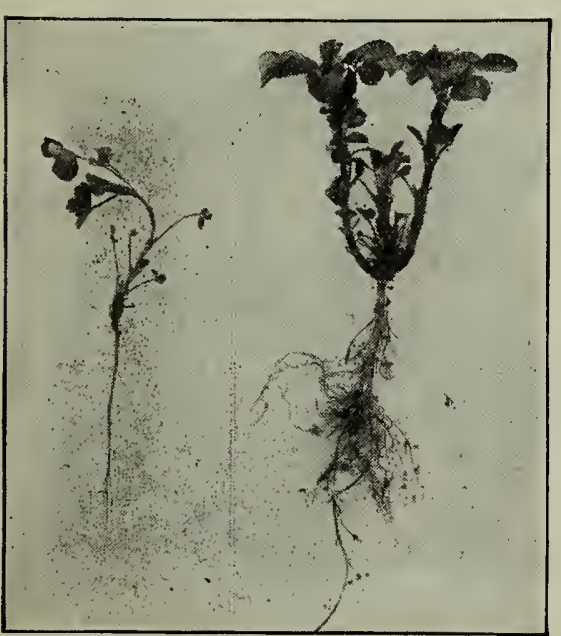

Uninoculated ALFALFA Inoculated The contrast speaks for itself.

Pure Ground Bone. Excellent for lawns, gardens, etc. Price, per 50 lbs., $\$ 1.50$, per $100 \mathrm{lbs}$., $\$ 2.50$.

Land Plaster. Price, per bag (100) lbs.),

Agricultural Lime. Price, per Bag (100 lbs.), $\quad .60$

Bordeaux Lime. Price, per Bag (100 lbs.),

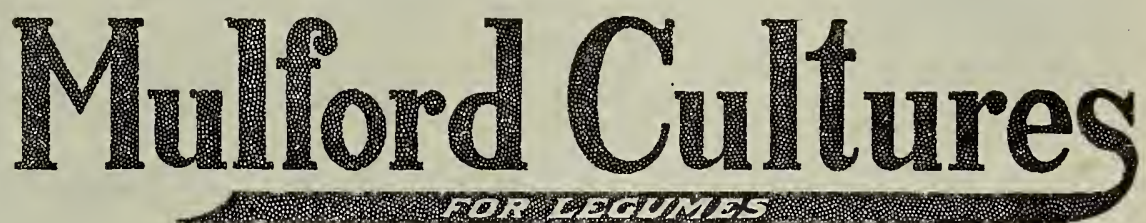

Mulford Cultures contain pure, tested strains of active, vigorous nitrogen-fixing bacteria for inoculating seeds of legumes or soil.

The United States Department of Agriculture and many State Agricultural Experiment Stations recommend inoculation of legumes with nitrogen-fixing bacteria to induce a prompt " catch" and increase your yield.

Mulford Cultures are prepared for

ALFALFA
CRIMSON CLOVER
SWEET CLOVER
RED CLOVER
ALSIKE CLOVER
COW PEAS

SOY BEANS
VETCH
VELVET BEANS
SWEET PEAS
GARDEN PEAS
GARDEN BEANS
LIMA BEANS

Be sure to specify the particular legume on which you desire to use the Mulford Cultures, otherwise we will not know how to fill your order. Prices: 5 -acre size $\$ 5.00,1$-acre size $\$ 1.50$, garden size $\left(\frac{1}{4}\right.$-acre) $50 \mathrm{c}$., trial size $25 \mathrm{c}$.

Free descriptive literature sent upon request. 


\section{Sterling Sanitary Wire Fencing}

\section{Style "F" Fabric}

is our most popular and closest mesh sanitary fence. Pickets full weight, full height, full guage No. 9 heavily galvanized wire spaced $1 \frac{3}{8}$ inches apart at bottom, $2 \frac{7}{8}$ inches at top, making fence absolutely chicken tight.

Best heights are 36,42 , and 48 inches. Other heights from 24 up to 84 inches made to order.

Style " $F$ ' Price per Lineal Foot

36-inch, 11c., 42-inch, 12c., 48-inch, $13 \mathrm{~s} / 2 \mathrm{c}$.

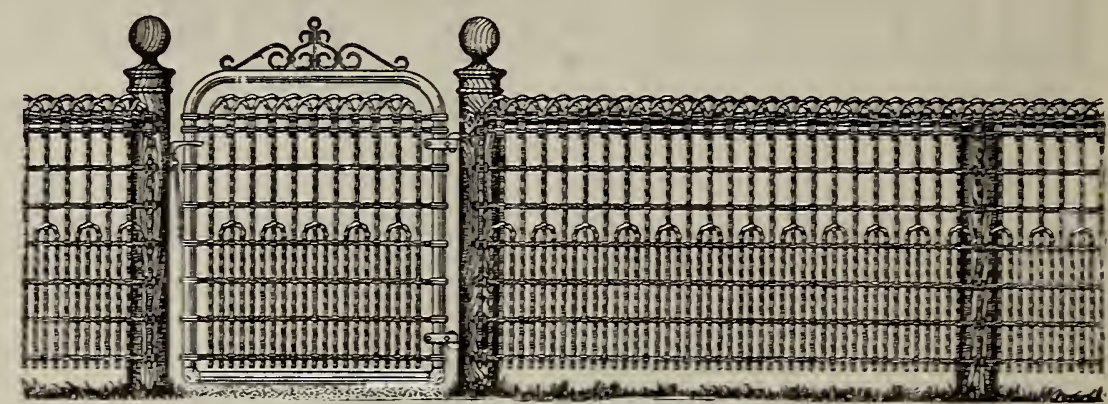

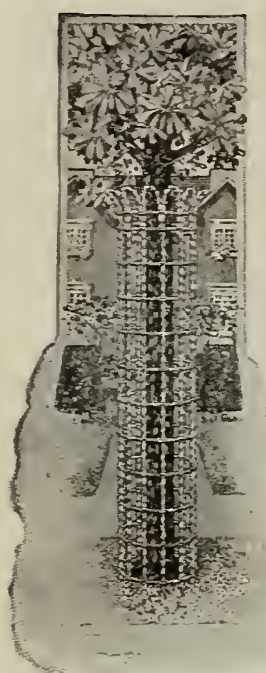

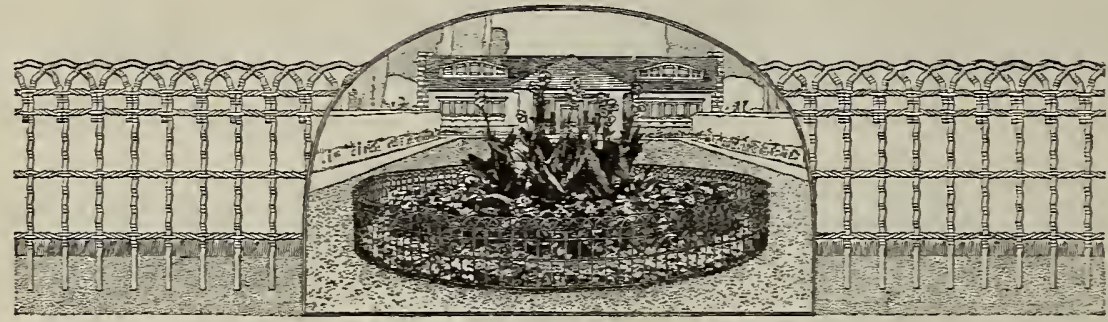

Sterling Tree Guards

let in fresh air and sunlight around the trees. Made 6 feet high of heavily galvanized wire in 3 diameters.

Price, each, 9-inch diameter, $\$ 1.00,12$-inch diameter, $\$ 1.10,15$ inch diameter, \$1.25.

\section{Sterling Flower Bed Sterling Vine Trellis} Border

fits any shape or form of flower bed. Ends left straight to be inserted in the ground. No posts neccables No. 13, heavily galcables No. 13
vanized wire.

Price per lineal foot, 16 inch height, $71 / 2 \mathrm{c}$., 22-inch beight, $81 / 2 \mathrm{c}$.

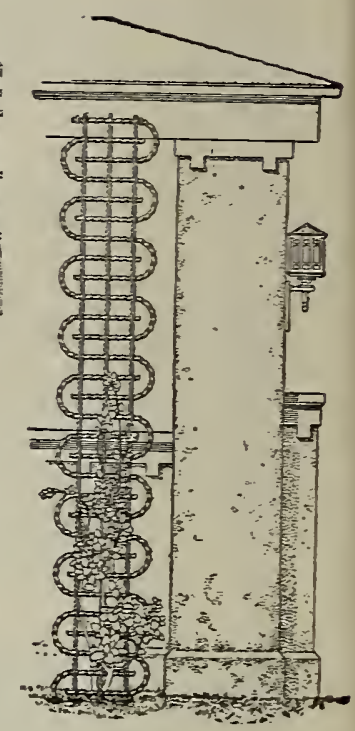

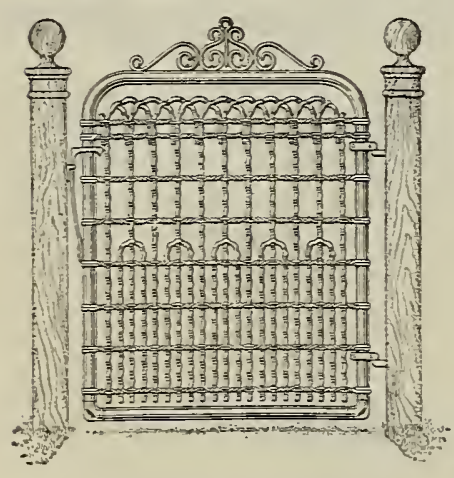

\section{Sterling Ornamental Walk Gates}

Frames made of heavy high grade steel tubing with ornamental scroll tops and style "F" Fabric; furnished with wood posts hinges and latch, ready to hang to posts.

Choice of 36,42 or 48 inch heights.

Price 3-foot opening, $\$ 3.00$, Price $31 / 2$-foot opening, $\$ 3.50$.

\section{Sterling Universal Gates}

Suitable for any home. Practical for front or back yards. Frames of heavy high carbon steel tubing $1 \frac{1}{8}$ inches in diameter; fabric style " $F$ ". Furnished with wood post hinges and latch. Choice of 36,42 or 48 -inch heights. Price 3-foot opening, $\$ 2.50$, Price, $31 / 2$ foot opening, $\$ 3.25$.

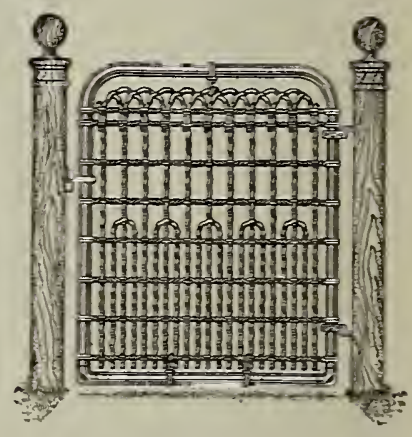

\section{Dutch Bulbs for Fall Planting}

Those beautiful early spring flowers you so much admire are the result of only a small amount of labor in the fall.

Our special Bulb Catalogue of Tulips, Hyacinths, Narcissus, Crocus, Lilies, etc., we issue September 1st. This catalogue we gladly mail to those interested. Send full name and address that we may send you a copy.

Special prices quoted on large orders to be packed separately at the grower's and shipped with our general consignment. These orders must be in our hands by July 1 st. 


\section{Genuine "Philadelphia" Lawn Mowers}

\section{Standard Mowers of the World}

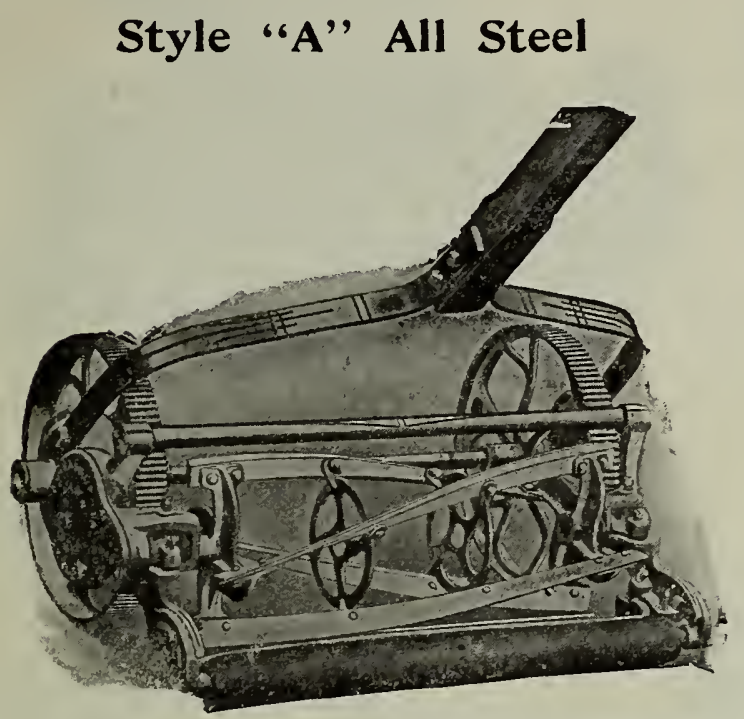

Superior in all points, being made entirely of steel, is much lighter in weight and draft. Having long and large bearings, is more durable and its construction perfect for fine work. 10-inch wheels, 4 blades, $6 \mathrm{r} / 2$-inch cylinder, Train of Three gears, double ratchet making both wheels drivers. Prices, 17-inch, $\$ 16.50,19$-inch, $\$ 17.50,21$-inch, $\$ 18.50$.

\section{Style "E" High Wheel}

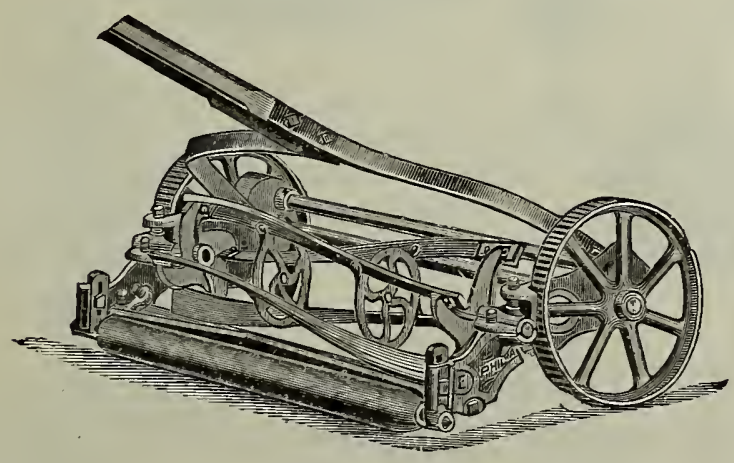

In construction it is simple, light in draft, and durable. Prices, 17 -inch, $\$ 12.50,19$-inch, $\$ 13.50$, 21-inch, $\$ 15.00$.
Style "K",

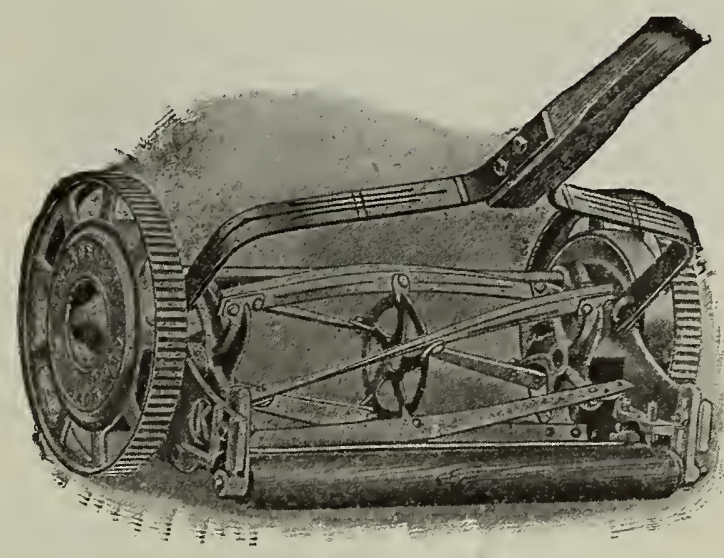

High wheels, it runs light, five knives, it cuts smooth and even. They always give satisfaction. Prices, 16 -inch, $\$ 10.50$, 18-inch, $\$ 11.50,20$ inch, $\$ 12.50$.

\section{Style ALL DAY}

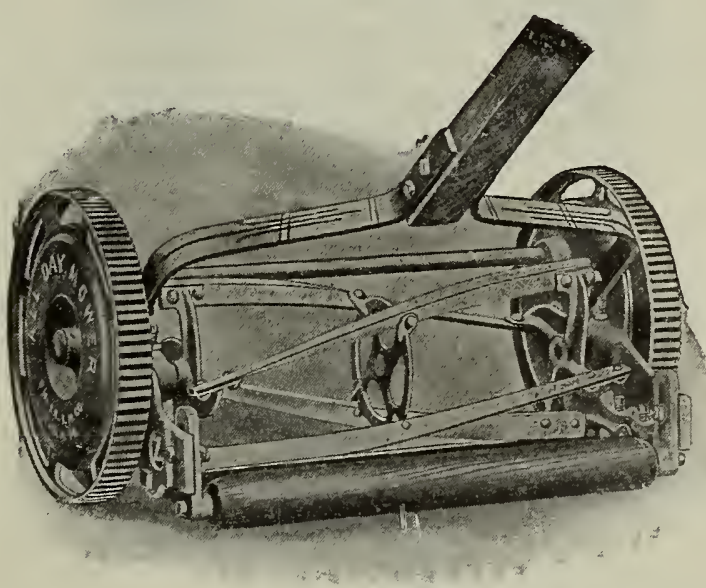

It is the superior of all others of its class. It is mechanically proportioned so as to run light and do fine work. 10-inch wheels, 4 blades, $61 / 2$-inch cylinder, single pinion, geared on both sides. Prices, 16-inch, $\$ 8.00$, 18-inch, $\$ 8.50$. 


\section{Genuine "Philadelphia" Lawn Mowers}

\section{Style UNIVERSITY}

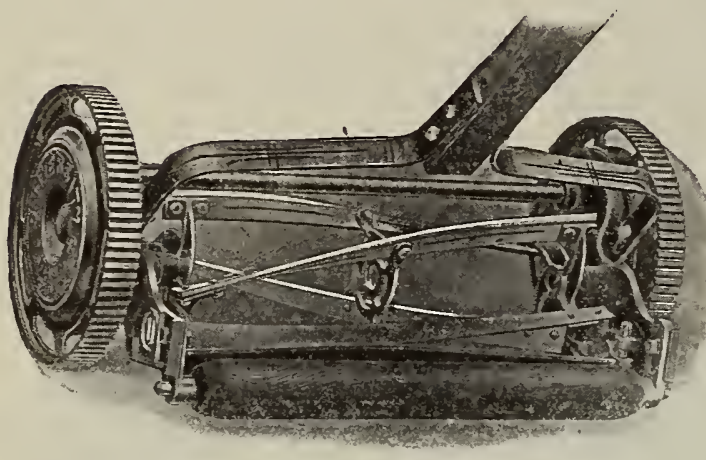

9-inch Open Wheels, 4 Blades, 5 1 2 -inch Cylinder, Single Pinion, Geared on both sides. Prices: 16-inch, $\$ 7.00$, 18-inch, $\$ 7.50$.

\section{Style DEWEY}

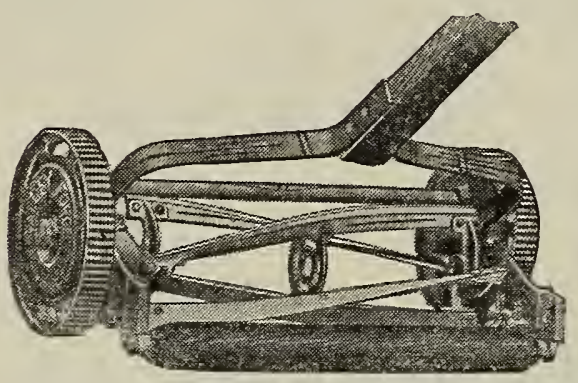

8-inch Wheels, 4 Blades, 51/4-inch Cylinder, Single Pinion, Geared on both sides. Prices: 14inch, $\$ 6.00,16$-inch, $\$ 6.50$.

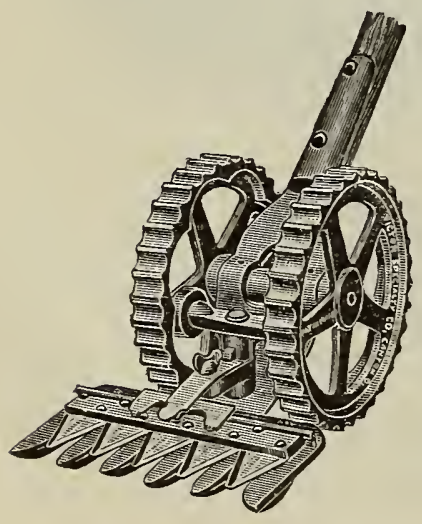

Style NEW

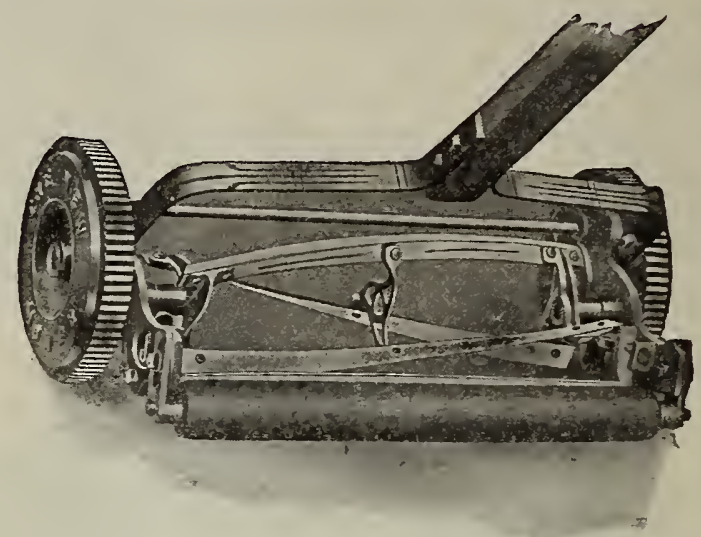

8-inch Wheels, 3 Blades, 51/4-inch Cylinder, Single Pinion, Geared on both sides. Prices: 14inch, $\$ 4.00,16$-inch, $\$ 4.25$.

\section{Philadelphia Improved EAGLE Horse Mower}

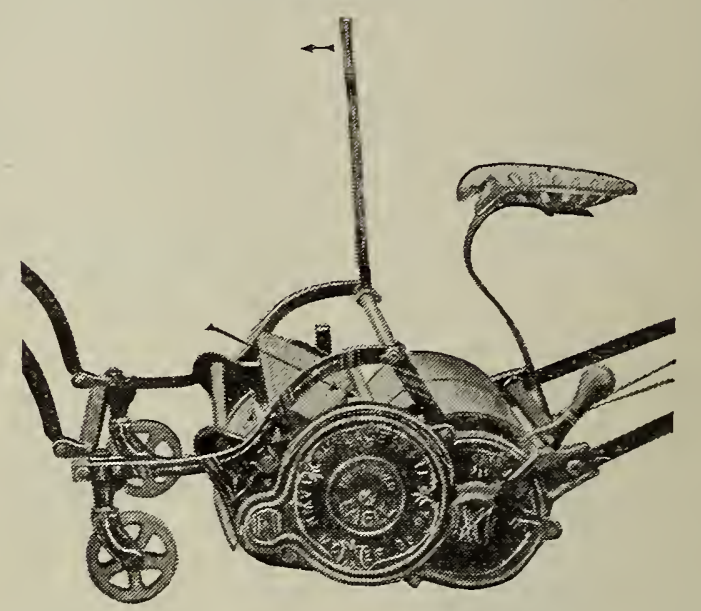

Illustration shows the Mower with Frame Raised so as to clear obstructions on lawns, walks, etc. Price, 30 -inch, 5 blades, $\$ 80.00$. With seat and shafts and draft pole and side draft attachment.

\section{The Victor Grass Clipper and Handy Lawn Trimmer}

Indispensable on every well-kept lawn. A perfect and convenient implement for trimming around trees and 'shrubbery and along walls and hedges and other places that cannot be reached with the lawn mower. 
RUBBER GARDEN HOSE

25 and 50 foot lengths coupled

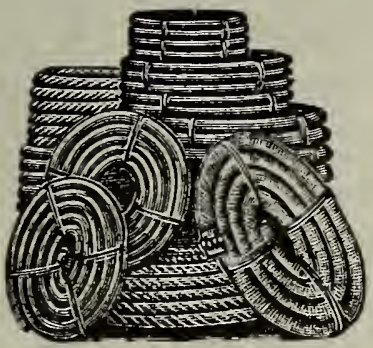

DUNHAM "WATER-WEIGHT" ROLLER

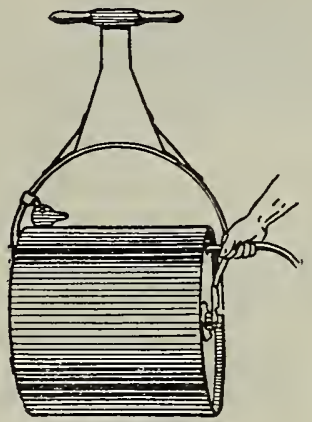

The Dunham "Water-Weight" Roller is electric welded, making the water section one solid drum. No rivets are used. It cannot leak. The rolling surface is perfectly smooth, and cannot cut up the lawn. They are roller bearing and easy to operate. Made in one section, as shown in cut, or with two sections. The handle lock attachment locks the handle to the drum when the roller is not in use, so that the handle remains upright. "Ask for a free copy of "Proper Care of Lawns."

$\begin{array}{llll}\text { Diam. } & \text { Length Sec- } & \text { Weight } & \text { Filled with } \\ \text { No. Inches Inches tions } & \text { Empty } & \text { Water } & \text { Price }\end{array}$ $9 \mathrm{r} / 2$ cents per foot $81 / 2$ " " " 12 " " 11 WB 3 Flushing- $3 / 4$-inch, 5-ply Tornado- $3 / 4$-inch, 5 -ply 1/2-inch, 5-ply Market-1/2-inch, 4-ply Princeton Cotton- $3 / 4$-inch $\mathrm{r} / 2$-inch

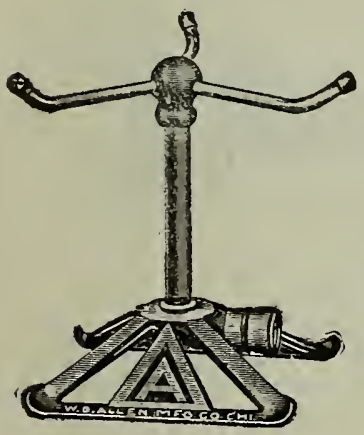

\section{"Mayflower" Lawn Sprinkler}

On sled base; 3-arm revolving.

Price, $\$ 1.25$.

By Parcel Post, $\$ 1.40$.

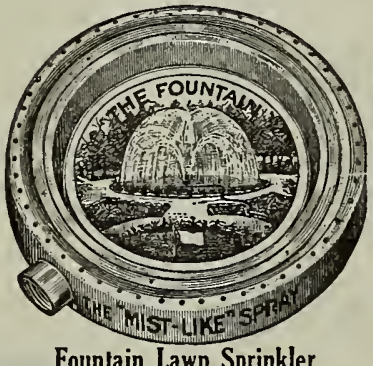

Founlain Lawn Sprinkler Made of heavy brass. Price, 50c., by Parcel Post, 55c.

WB 7

WB 9

WB 11

WB 13

$\begin{array}{lll}14 & 20 & 1 \\ 18 & 24 & 1 \\ 24 & 24 & 1 \\ 24 & 32 & 1 \\ 18 & 24 & 2 \\ 24 & 32 & 2\end{array}$

65 lbs.
80 “،
115
130 “.
100
260 “.

200 lbs.

310 "

500 “

650 "“

330 “

650 “

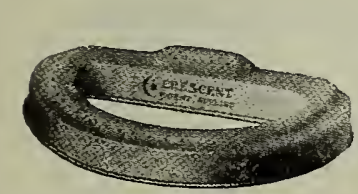

The "Crescent"

\section{The "Crescent" \\ Lawn Fountain Sprinkler \\ It throws all the water to the front and sides. \\ Price, 50c., by Parcel Post, pre- paid, 55c.}

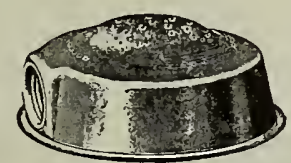

"Square Fountain"

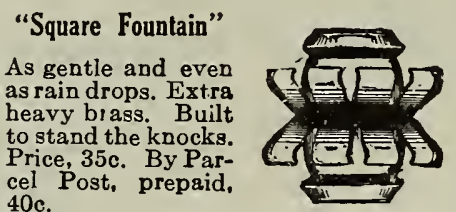

\section{Perfect Glinching Hose Mender}

It leaves the hose as smooth and strong and tight as a new hose.

$1 / 2$ and $3 / 4$-inch each. 10c. Doz. $\$ 1.00$.

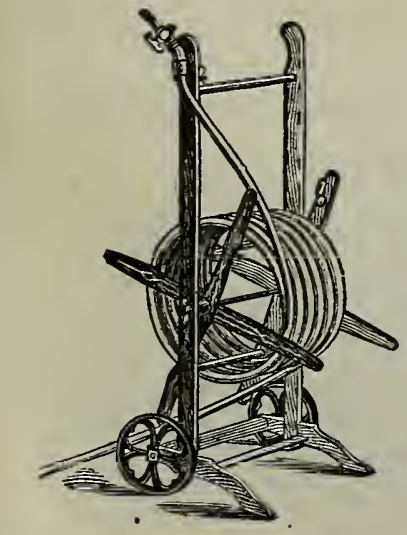

\section{Hose Reels}

Wood, $\$ 1.00$ each. All iron, $\$ 1.50$ and $\$ 2.50$

\section{Watering Pots}

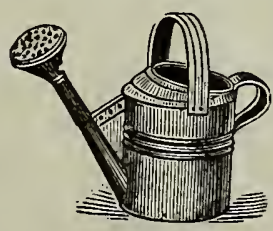

4 quart Galvanized Iron 40c. each

6 quart Galvanized Iron 50c. "“

8 quart Galvanized Iron 60c. “”

10 quart Galvanized Iron 70c. "

12 quart Galvanized Iron 85c.

16 quart Galvanized Iron $90 \mathrm{c}$.

1 quart Painted Tin Parlor 40c.

2 quart Painted Tin Parlor 45c.

4 quart Painted Tin Parlor 65c.

6 quart Painted Tin Parlor 80c.

8 quart Painted Tin Parlor $\$ 1.00$ “

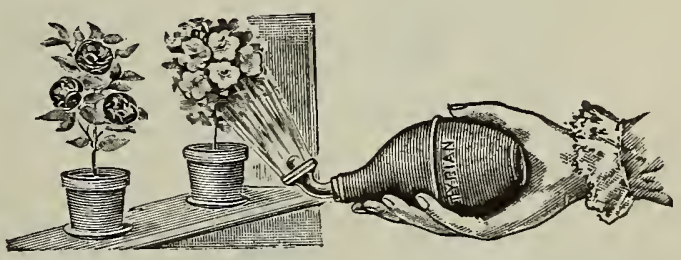

\section{“TYRIAN" Plant Sprinklers}

For sprinkling plants and flowers in house or garden.

4 oz. size, bent neck

6 oz. size, bent neck

8 oz. size, bent neck

$10 \mathrm{oz}$. size, bent neck

$4 \mathrm{oz}$. size, straight neck

6 oz. size, straight neck

8 oz. size, straight neck

10 oz. size, straight neck
$60 \mathrm{c}$. each

$70 \mathrm{c}$. “"

$80 \mathrm{c}$. "

90 c.

$50 \mathrm{c}$

60 c. "

$75 \mathrm{c}$.

$85 \mathrm{c}$. 


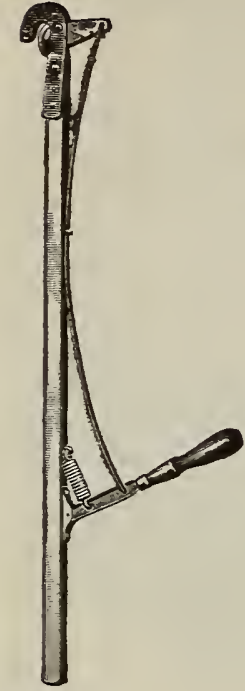

Standard Pruner

BUDDING AND PRUNING KNIVES

50 c., 75 c., $\$ 1.00$ each.

\section{PRUNING SHEARS}

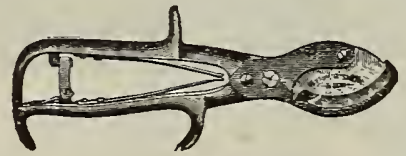

Taylor Pattern, with coil spring, 9 inches California Pattern, with volute spring

9 inches, - - - - - - $\quad$ - $\quad$ " 50

Swiss Pattern, polished, 9 inches - - - “ 1.50.

Levin Pattern, 7 inches, - $\quad$ - $\quad$ - $\quad$ - $\quad$ “ $\quad \mathbf{5 0}$

Sent by parcel post, prepaid.

\section{WIRE FRUIT PICKER}

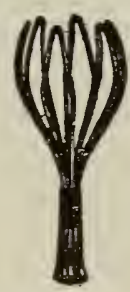

Each, 25c.

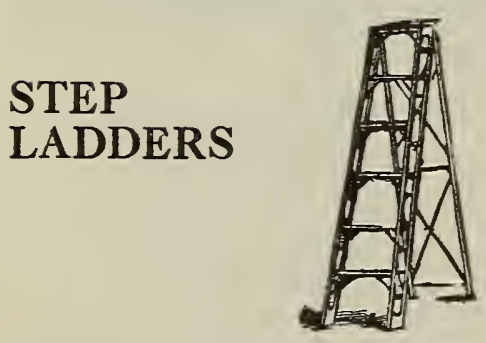

GARDEN LINE REEL

Hub, per foot - - 35c. Challenge, " " - - 45c. Imperial, “ " - - 35c.

\section{ASBESTOS TORCH}

It will be found $\mathrm{ex}$ ceedingly effective in destroying nests of caterpillars, so destructive to fruit and shade trees. Attach the torch to the end of a pole of suitable length; saturate with kerosene oil, light, and hold under the nests.

Price, 25c.

By Mail, 35c.

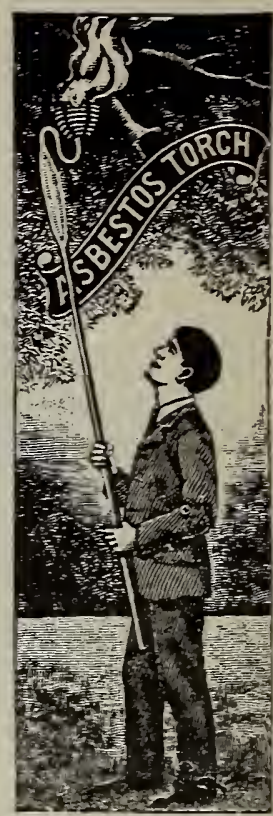

\section{UNIVERSAL PRUNING SAW}

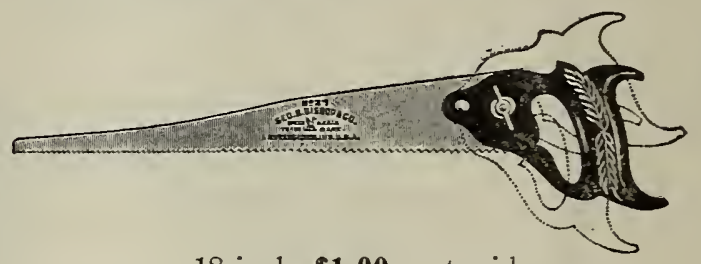

18 inch, $\$ 1.00$ postpaid

\section{TROW BRSDGES GRAFTING WAX,}

The best on the market. $\frac{1}{4}$ lb. pkg. 10c.; $\frac{1}{2} \mathrm{lb}$. pkg. $15 \mathrm{c}$.; $1 \mathrm{lb} . \mathrm{pkg} .25 \mathrm{c}$.

\section{GRAFTING GHISEL}

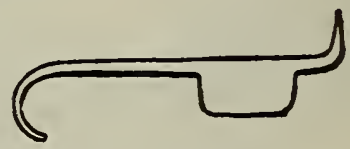

Made from the finest cast steel. Frice, each - - - - - 60c.

\section{Cahoon Broadcast Seeder}

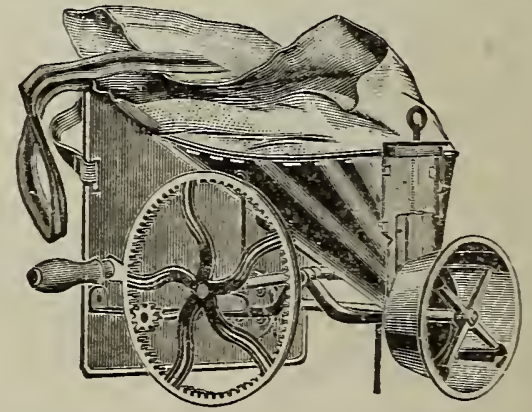

Sows all kinds of clover, grass and grain seeds; it will throw forty feet.

Parcel post weight, 9 lbs. Price, $\$ 3.00$ 

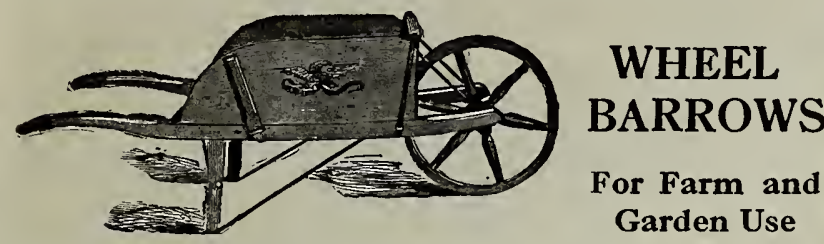

Chicopee Garden. This Barrow is made from the best seasoned timber. The end of the bottom is cut into the back sill, thus preventing the splitting or breaking of the bottom boards. The wheel has a cast iron hub with white oak or ash spokes and rims. The axle is wrought iron, with turned arbors.

Price: No. $1, \$ 4.50$; No. $2, \$ 5.50$; No. $3, \$ 6.50$.

\section{"AMES" BEST QUALITY}

Price: No. 3 , $\$ 4.50$; No. 4 , $\$ 4.75$; No. 5 , $\$ 5.50$; No. 6 , $\$ 6.00$.

\section{GHICOPEE LEAF RACK}

This can be attached to any size wheel-barrow. It is most convenient for gathering leaves, cut grass and rubbish. It can be taken apart, occupying but little space when not in use.

Price, $\$ 5.00$.

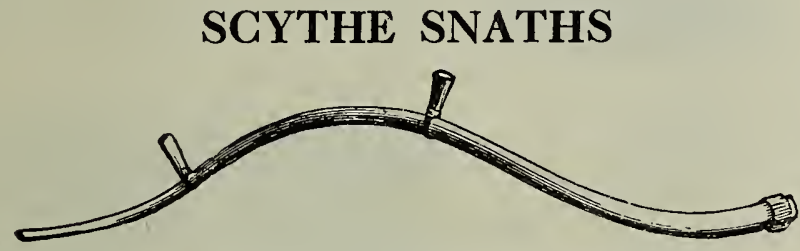

No. 50 Regular Scythe, - $\quad$ - $\quad$ - $\quad$ - 90c " 100 Bush. - $\quad$ - $\quad$ - $\quad$ - $\quad$ - $\$ 1.00$ SGYTHES

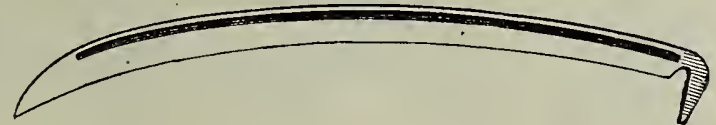

Little Giant, Solid Steel, $\$ 1.00$

Conqueror, - - 90c Clipper,

Heavy Bush, - - $\$ 1.00$ Bramble, or Light Bush, 1.00
Boothby Toothed Hoe

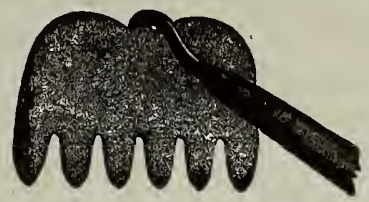

Price, each, 85c Arlington Scuffle Hoe 1

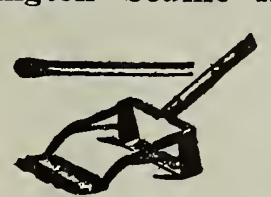

8 in. and 9 in. blades.

Each, $\$ 2.00$

\section{GARDEN HOES}

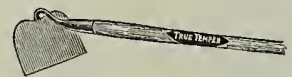

Socket, each, $\mathbf{6 5 c}$

Shank, each, 60c Automatic Selí-Cleaning Lawn Rake]

\section{Potato Hooks}
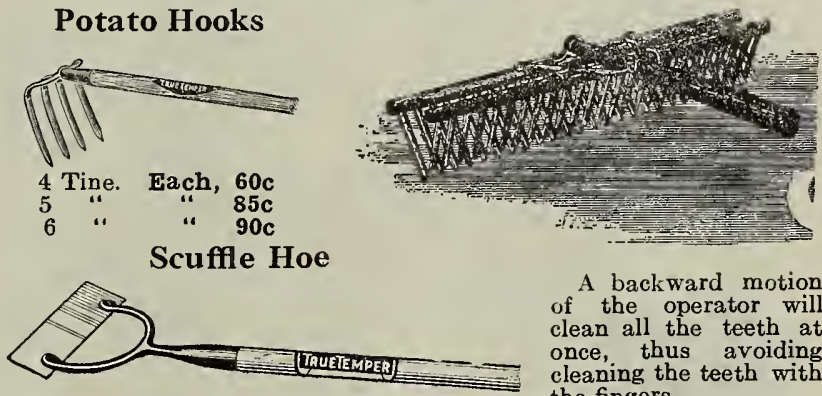

A backward motion of the operator will clean all the teeth at once, thus avoiding cleaning the teeth with the fingers.

8 in., $70 c$

26 teeth, 60c 52 teeth, 85c

MANURE FORKS

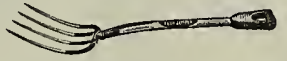

Each

4 Tine D handle, $\$ .90$

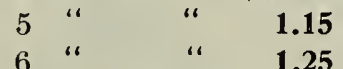

1.25

SPADING FORKS
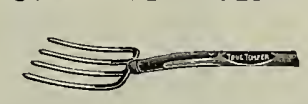

12 tooth, Malleable Iron, $30 \mathrm{c}$

14 " " " "

16 " " $" 75 c$

GIBBS' LAWN RAKE

Made of heavy tinned steel wire. These re excellent for lawn or walk work.

24 tooth. Each, 40c 36 " " $60 \mathrm{c}$

Each, $\$ 1.00$

4 Tine $D$ handle. 4 Tine long

SCYTHE RIFLES

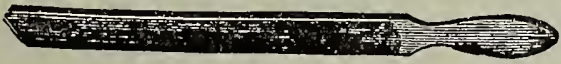

Meadow King, 8c Farmers' Friend, 8c

\section{SCYTHE STONES}
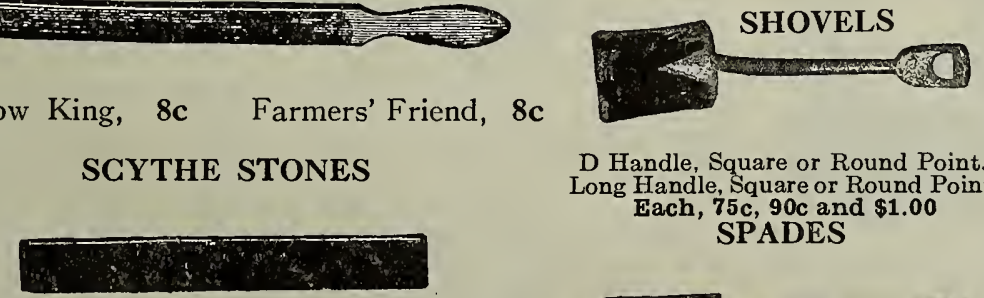

D Handle, Square or Round Point.
Long Handle, Square or Round Point. Long Handle, Square or Round Point. SPADES

.95

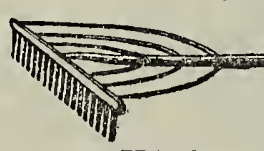

HAY FORKS

Wood Lawn

\section{Rakes}

26 teeth. Each, 50c

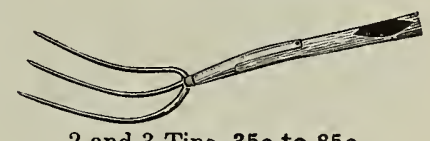
GRASS HOOKS

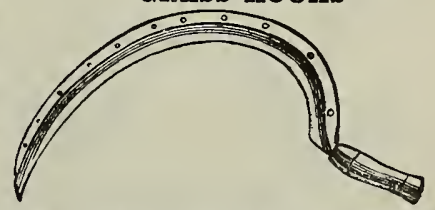

Village Boy, each, 50c Meadow King, each, 25c
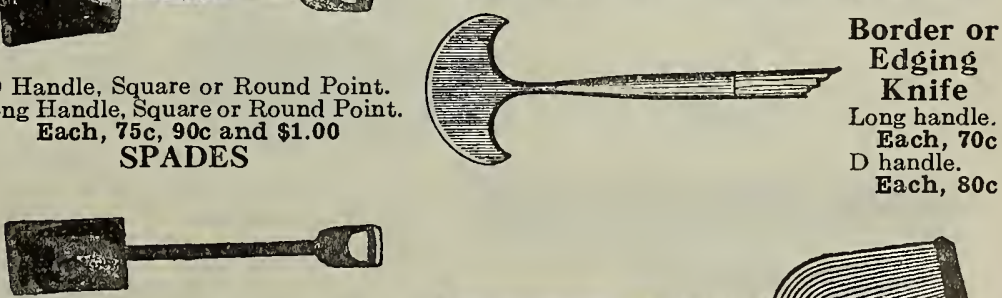

Crescent, - - - - - - - $8 \mathrm{c}$

Black Diamond, fine, - - - - $\quad-10 \mathrm{c}$

Imported English, round, - - - - 25c

Carborundum,

- $25 c$
D Handle. Each $85 \mathrm{c}$ Long, "

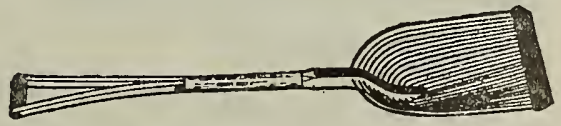

WIRE VEGETABLE SCOOP Price 75c 

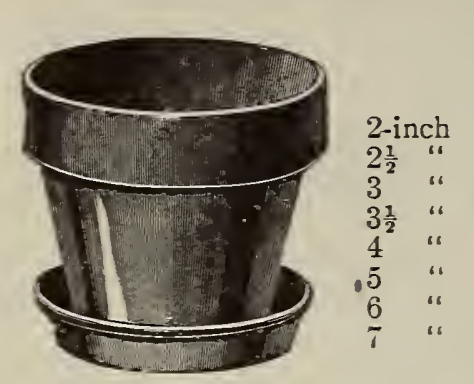

STANDARD FLOWER POTS

\section{Earthenware}

Each
$\vdots$
.
.03
.04
.05
.07
.10

\begin{tabular}{|c|c|}
\hline $\begin{array}{r}\text { Doz } \\
.10\end{array}$ & 8-inch \\
\hline & \\
\hline .15 & 10 “" \\
\hline .20 & $\begin{array}{ll}11 & \text { " } \\
12 & \end{array}$ \\
\hline .40 & 14 “ \\
\hline .65 & 16 \\
\hline 1.10 & $\begin{array}{l}18 \\
20\end{array}$ \\
\hline
\end{tabular}

Inside measurement, width and depth equal.
FLOWER POT SAUCERS

3 -inch \$ .02 ea.\$ .12 doz.

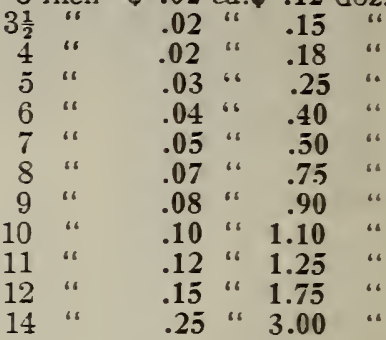

BULB PANS

Earthenware

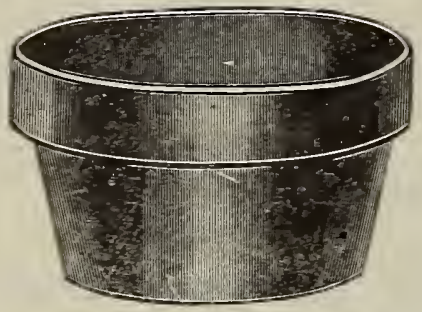

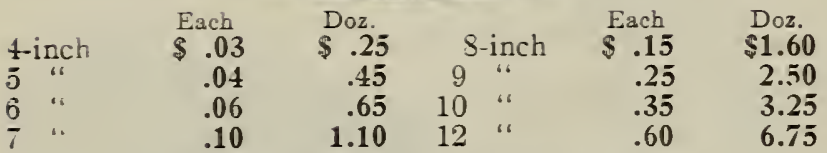

PEIRCE PAPER FLOWER POTS

The Peirce Paper Flower Pot is a

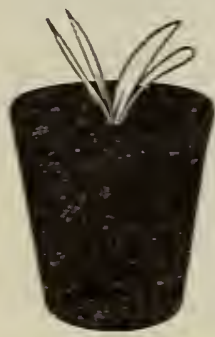

waterproof paper pot made from a tough fibre paper, and is especially adapted to the florist, gardener and nursery trade.

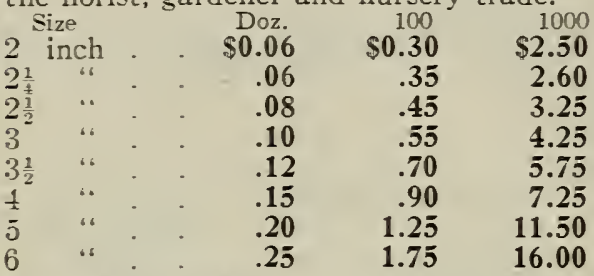

WIRE HANGING BASKETS
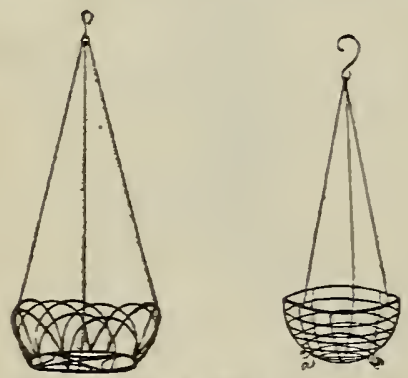

No. 35. No, 37 Moss Basket

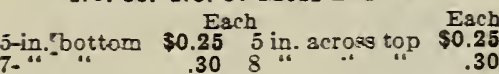
$9-. " . \quad .35$

\section{RAFFIA}

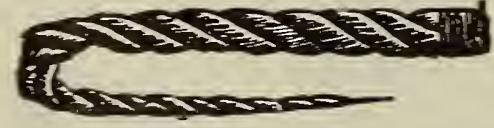

For tying plants.

Per lb., 25c.; 5 lbs., $\$ 1.10$
Garden Arch

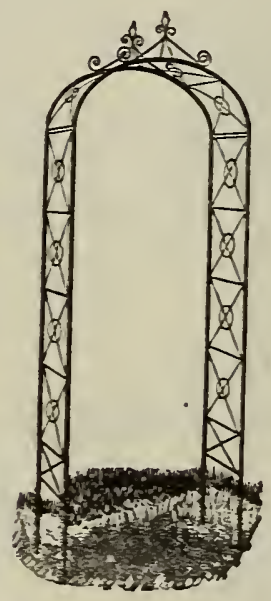

Whole Price 5 ft. 12 in. 21 ft $\$ 4.50$

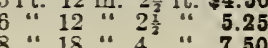

Made of Steel and Wre. Painted green

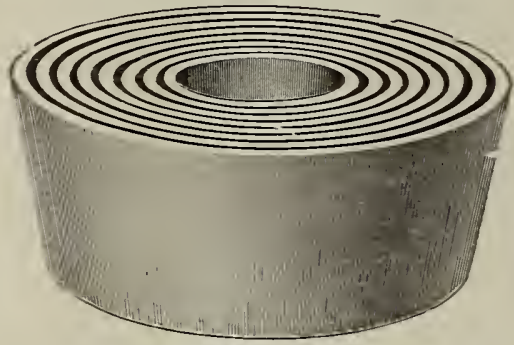

FERN PANS

Earthenware

Size Each Doz. $4 \times 1 \frac{7}{8}$ inches .04 .36 $4 \frac{3}{4} \times 2 \frac{1}{5}$ " $\quad .05 \quad .50$ $5 \frac{1}{2} \times 2 \frac{1}{4} \quad$ " $\quad .06 \quad .60$ $6 \frac{1}{4} \times 2 \frac{1}{2} \quad$ " $\quad .08 \quad .75$ $7 \times 2 \frac{5}{8} \quad$ " $\quad .09 \quad .90$ $8 \times 3 \frac{1}{8}$ “ .101 .20

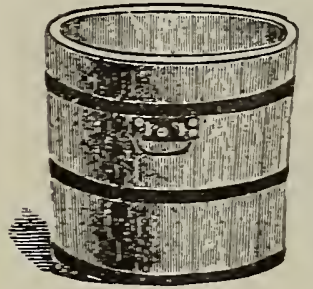

OAK PLANT TUBS

$12 \times 11$ inches

$14 \times 12$

$16 \times 13$

$18 \times 15$

$20 \times 17$

$24 \times 20$

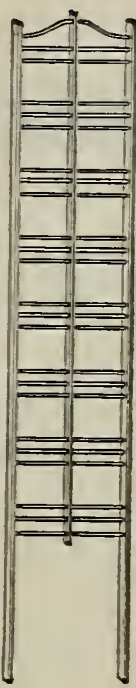

$1 \frac{1}{2} \mathrm{ft}$.

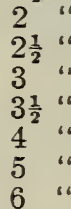

$2 \frac{1}{2}$
3
$3 \frac{1}{2}, "$
4
5
6

\section{WOOD DOWEL STAKES}

Length
24 inches
30 "
36

Diam.

Doz.

$\$ 0.15$

36
VERANDA TRELLISES

Made of Wood and Rattan, painted green

\begin{tabular}{|c|c|c|c|}
\hline 2 & feet & .60 & eacl \\
\hline 3 & 16 & .70 & $" 6$ \\
\hline 4 & "“ & .75 & ") \\
\hline $5 \times 1 \frac{1}{2}$ & “" & 1.15 & 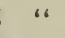 \\
\hline$\times 1 \frac{1}{2}$ & “" & 1.40 & \\
\hline x $1 \frac{1}{2}$ & “" & 1.65 & \\
\hline$\times 1 \frac{1}{2}$ & $"$ & 1.90 & \\
\hline$x 1 \frac{\tilde{z}}{3}$ & " & 2.15 & \\
\hline$\times 1 \frac{2}{3}$ & “ & 2.50 & \\
\hline 1 & " & 2.90 & \\
\hline & “" & 3.25 & \\
\hline
\end{tabular}

$\$ 6.00$ per dozen 7.00 " " 8.00 13.00 15.00 18.00 21.00 24.00

28.00 32.00 36.00

\section{PLANT STICKS}

For Greenhouse or Garden use. Square. Painted green.

$\begin{array}{rrr}\text { Each } & \text { Doz. } & 100 \\ \$ 0.03 & \$ 0.25 & \$ 1.35 \\ .04 & .30 & 2.00 \\ .05 & .42 & 3.00 \\ .07 & .65 & 4.75 \\ .08 & .75 & 5.50 \\ .09 & .85 & 6.50 \\ .12 & 1.20 & 8.50 \\ .15 & 1.40 & 10.50\end{array}$




\section{GALVANIZED STEEL PLANT BOX}

This box has a patented bottom which gives the plants perfect drainage, and at the same time does not leak. The water receptacle runs full length of the box, and gives the roots a plentiful supply of clean water. It is made of strong, galvanized iron, neatly enameled in dark green Convenient and practical for indoor or outdoor use. No staining of paint or disfiguring in any way.

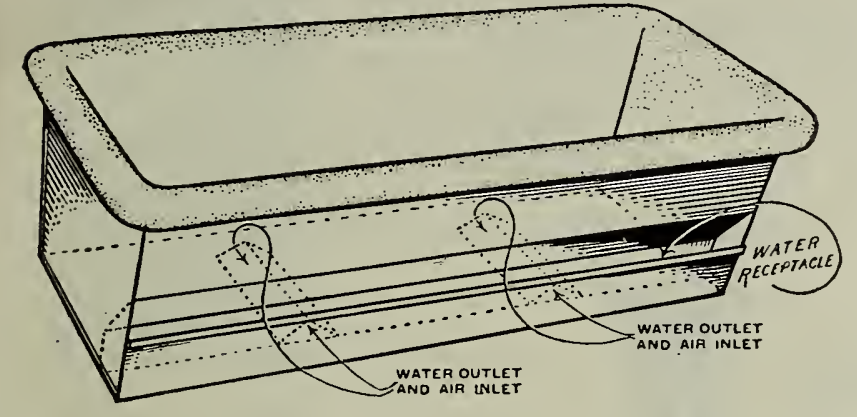

Length Width Depth Each Length Width Depth Each 12 in. $8 \frac{1}{2}$ in. $6 \frac{1}{4}$ in. $\$ 0.6532$ in. $8 \frac{1}{2}$ in. $6 \frac{1}{4}$ in. $\$ 1.50$ 18 “ $8 \frac{1}{2}$ “ $6 \frac{1}{4}$ “ $\quad .80 \quad 36$ “ $8 \frac{1}{2}$ “ $6 \frac{1}{4}$ “ 2.00

24 “ $8 \frac{1}{2}$ “ $6 \frac{1}{4}$ “ $\quad .90 \quad 38$ “ $8 \frac{1}{2}$ “ $6 \frac{1}{4}$ “ 2.25 28 “ $8 \frac{1}{2}$ “ $6 \frac{1}{4}$ “ 30 “ $8 \frac{1}{2}$ “ $6 \frac{1}{4}$ “ 1.1040 “ $8 \frac{1}{2}$ “ $6 \frac{1}{4}$ “ 1.2548 “ $8 \frac{1}{2}$ “ $6 \frac{1}{4}$ “

2.50

3.00

\section{WOOD LABELS}

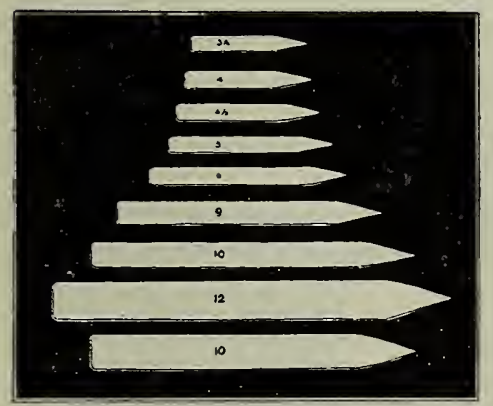

4- inch. Pot Label

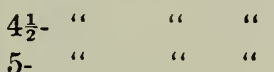

5- “ “ “ “ "

6- " " " "

8- " " Garden label

$10-$ " “ " " 12

$3 \frac{1}{2}-$ " Tree label, copper wired.

\section{GALVANIZED STEEL PLANT TUB}

Made on the same principle as the Plant Box.

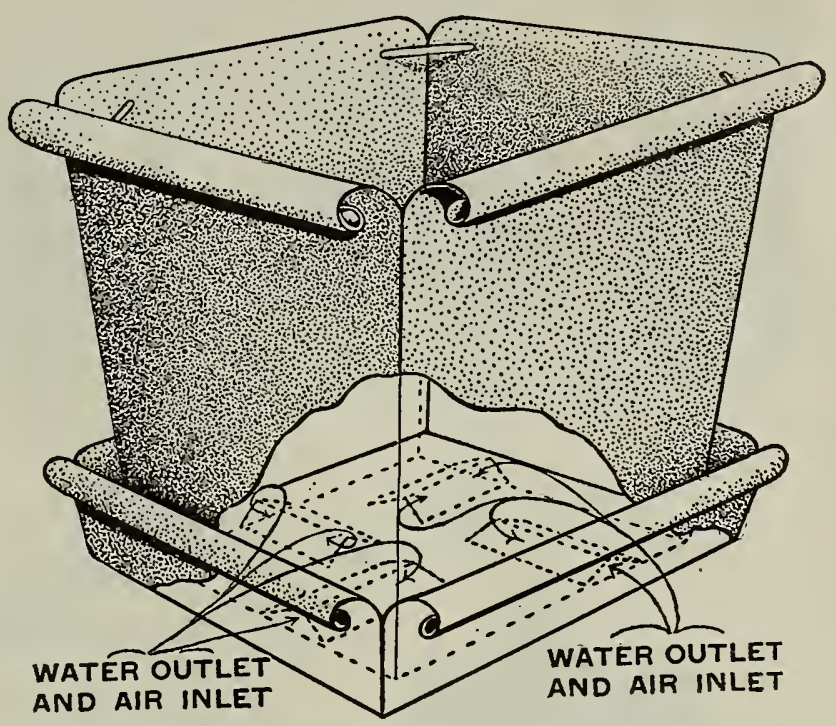

\begin{tabular}{|c|c|}
\hline Length & Width \\
\hline 10 inches & 10 inches \\
\hline $\begin{array}{ll}12 & \\
14 & \end{array}$ & $\begin{array}{l}12 \\
14\end{array}$ \\
\hline 16 & 16 \\
\hline
\end{tabular}

Price

$\$ 1.25$ each

1.50 "

2.00 "

2.50 "

3.00

\title{
THE SURE SHUT HOSE MENDER
}

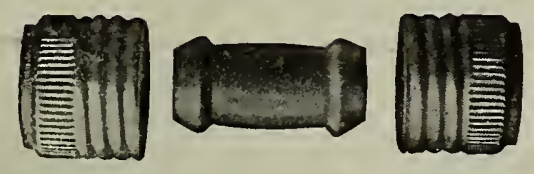

The simplest, strongest and best device on the market for repairing leaky hose.

No tools whatever are necessary to attach it.

Can be put on with the hands alone in less than a minute.

Makes an absolutely water-tight connection.

Is made entirely of brass, will not rust.

Will fit any make of hose.

Can be detached and used over and over again.

Price, 20c. Each, Parcel Post Prepaid.
Jumbo Powder Gun

\begin{tabular}{|c|c|c|}
\hline 100 & Plain 1000 & $\begin{array}{c}\text { Painted } \\
1000\end{array}$ \\
\hline$\$ 0.12$ & $\$ 0.60$ & $\$ 0.85$ \\
\hline .12 & .70 & .95 \\
\hline .15 & .80 & 1.10 \\
\hline .15 & 1.00 & 1.35 \\
\hline .50 & & 4.00 \\
\hline .60 & & 5.20 \\
\hline .75 & & 6.60 \\
\hline .20 & & 1.40 \\
\hline
\end{tabular}

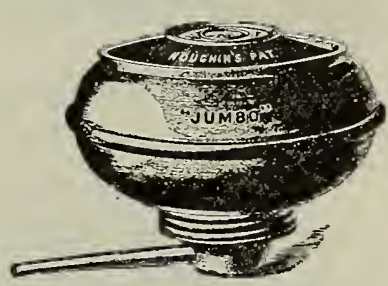

For applying insect powders on plants. Is 4 inches in diameter, holds about 4 oz. Price, 25c. each. By parcel post, 30c.

\section{BEAUTIFY YOUR LAWN}

\author{
WITH A PAIR OF
}

\section{REALISTIC LIFE SIZE}

\section{RABBITS}

Beautifully enameled in white with pink eyes and ears

Absolutely life like in appearance

PRICE, \$10.00 PER PAIR 


\section{FIBRE FLORISTS' VASES}

For displaying cut flowers

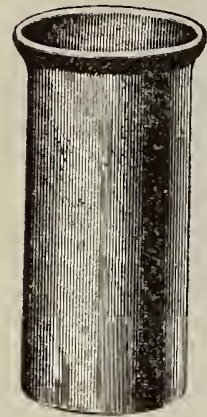

No.
0
1
2
3
4
00
11
22
33

\begin{tabular}{|c|c|c|c|c|}
\hline am. & \multicolumn{2}{|c|}{ Depth } & Each & Doz. \\
\hline & $13 \mathrm{i}$ & & $\$ 0.85$ & $\$ 10.00$ \\
\hline & $10 \frac{1}{2}$ & “ & .75 & 8.80 \\
\hline “" & 9 & “ & .65 & 7.60 \\
\hline " & $6 \frac{1}{2}$ & “ & .60 & 6.30 \\
\hline "6 & 5 & “" & .45 & \\
\hline 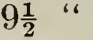 & 21 & " & 3.25 & 39.00 \\
\hline 6 & 18 & “" & .85 & 10.00 \\
\hline " & 15 & " & .75 & \\
\hline ‘ & 12 & " & .65 & \\
\hline & 9 & ، & .6 & \\
\hline
\end{tabular}

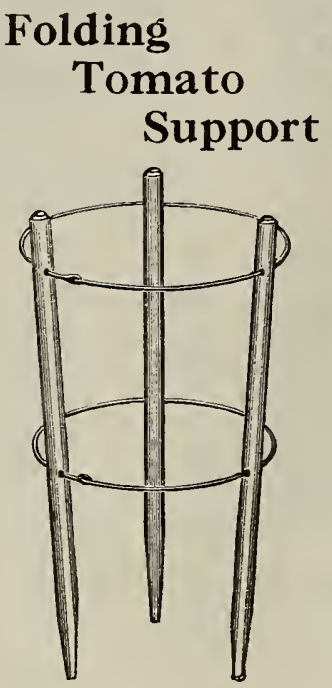

34 inches high. 20 inches in diamater at the top.

Goodell Double Point. P. P. Weight $1 \mathrm{lb}$.

\section{VERBENA BASKETS}

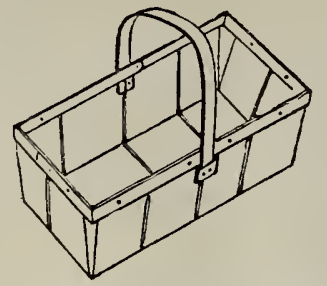

Size -12 inches long, 7 inches wide, 4 inches deep.

Adjustable wooden handles, with tin fastenings on the ends.

Per $100, \$ 3.00$; per $1,000, \$ 25.00$

Size-10 inches long, 5 inches wide, 3 inches deep.

Adjustable wooden handles, with tin fastenings on the ends. Per $100, \$ 2.00$; per $1,000, \$ 18.00$.

Size -10 inches long, 5 inches wide, 3 inches deep. Wire handle attached.

Per $100, \$ 2.00$; per $1,000, \$ 18.00$.

\section{BOUQUET HOLDERS-For Cemetery Use}

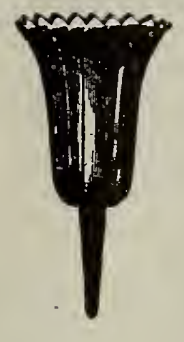

\section{Iron. Painted Green}

Small-Price, each, 25c.; doz., $\$ 2.50$

Med. " “ 30c.; “ $\mathbf{3 . 0 0}$

Large “ " 35c.; “ $\mathbf{3 . 5 0}$

Tin, painted green-Price, each, 10c.; doz., $\$ 1.00$

\section{GRASS SHEARS}

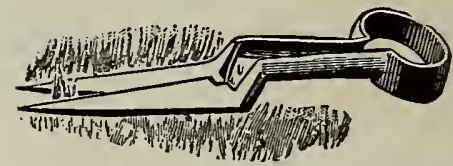

Lightning, 25c.; Sure Clip, 35c. each Parcel Post Weight, $1 \mathrm{lb}$.

\section{GARDEN TROWELS}

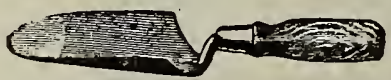

No. 25 Eagle . . . . 10c

No. 30 Socket Pattern : . 25c.

Keystone 6 inch . . . 40c.

Keystone 7 inch . . . 45c.
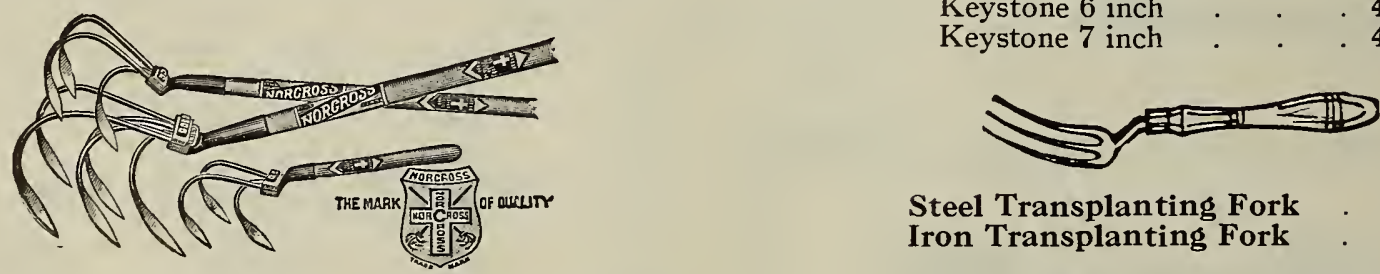

Steel Transplanting Fork . 35c. Iron Transplanting Fork . 10c.

MIDGET NORGROSS. Short handle for hand work.

Price, 25c.

3-PRONG NORGROSS. Light and can be used by women and children.

Price, 50c.

5-PRONG NORCROSS. The standard size. A wonderfully useful tool. Every man with a garden should have one.

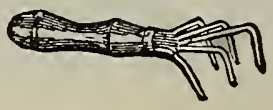

Excelsior Weeder

10c.

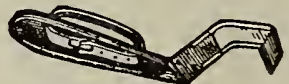

Haseltine Weeder

25c.

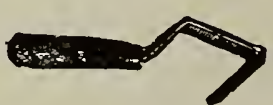

Lang Weeder

$25 c$. 


\section{Janitors' Sundries}

A complete stock of supplies for the janitor or for the household.

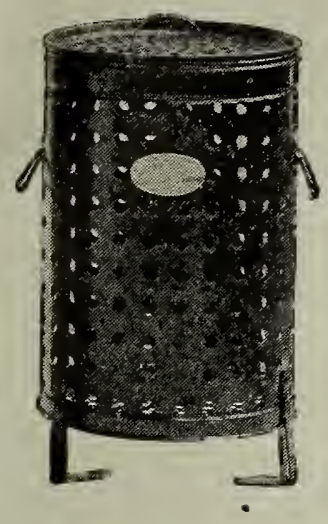

\section{SAFETY RUBBISH BURNERS}

Fire and sparks can't blow away and spread with these burners. The punched metal gives enough metal to hold the hot papers and ashes. Enough holes to burn up every bit. An easy way of disposing of rubbish that is always accumulating.

No. 1. Diam. $12 \frac{1}{2}$ in. Height 21 in. Price $\$ \mathbf{\$ 1 . 5 0}$

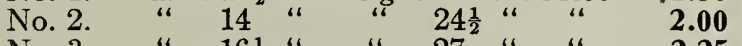

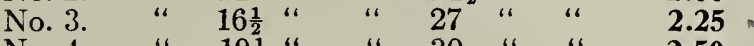

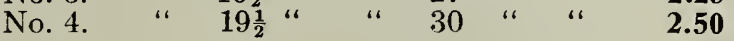

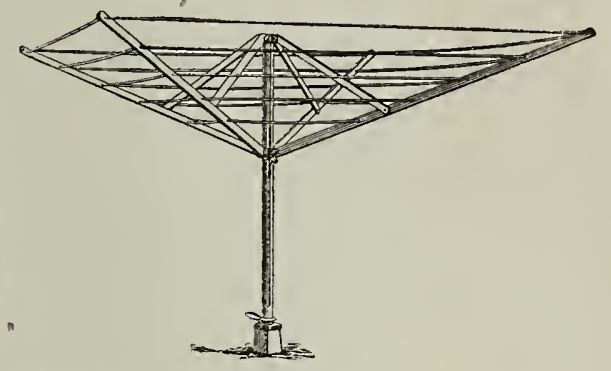

OUTDOOR CLOTHES DR YERS

Manilla or cotton line.

120 foot, 4-line. Each, \$3.50. 160 foot, 5-line. Each, \$3.75
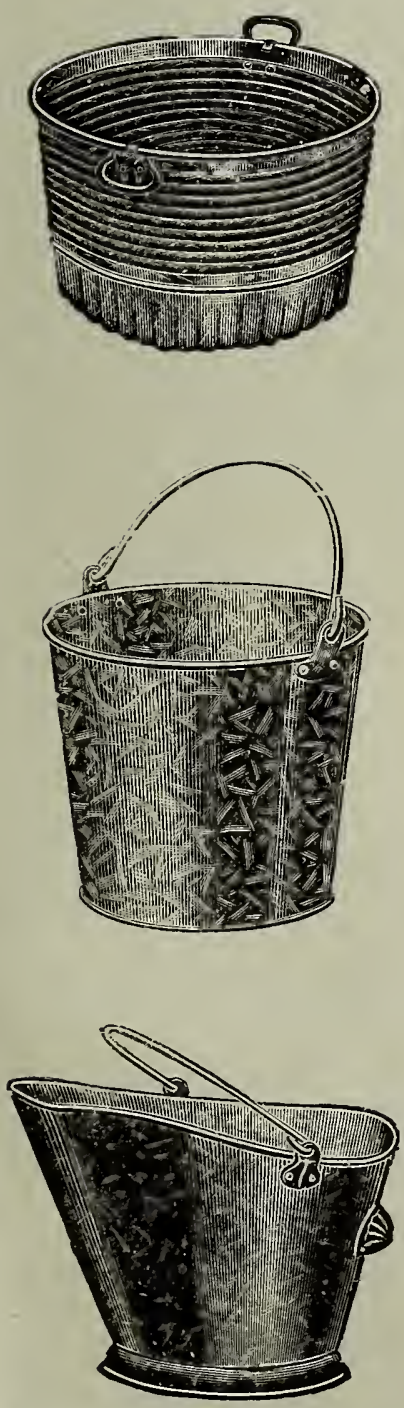

\section{Brooms}

Whisk Brooms

Floor Brushes

Dust Brushes

Furniture Brushes

Radiator Brushes

Scrub Brushes

Window Brushes

Nail Brushes

Dustless Mops

Mop Handles

Mop Wringers

Wash Tubs

Clothes Dryers

Clothes Line

Star Fibre Pails

$\begin{array}{ll}\text { Feather Dusters } & \text { Chamois Skins } \\ \text { Woven Down Dusters } & \text { Wooden Pails }\end{array}$

Dustless Dusters

Dust Pans

Cotton Mops

Metal Polish

Dry Mops

Liquid Cleaner

Sweeping Compound

Baskets for the Office and General Use

Galvanized Iron Pails

Galvanized Iron Garbage Cans

Galvanized Iron Ash Barrels

Wyandotte Detergent

Wyandotte Cleaner and Cleanser
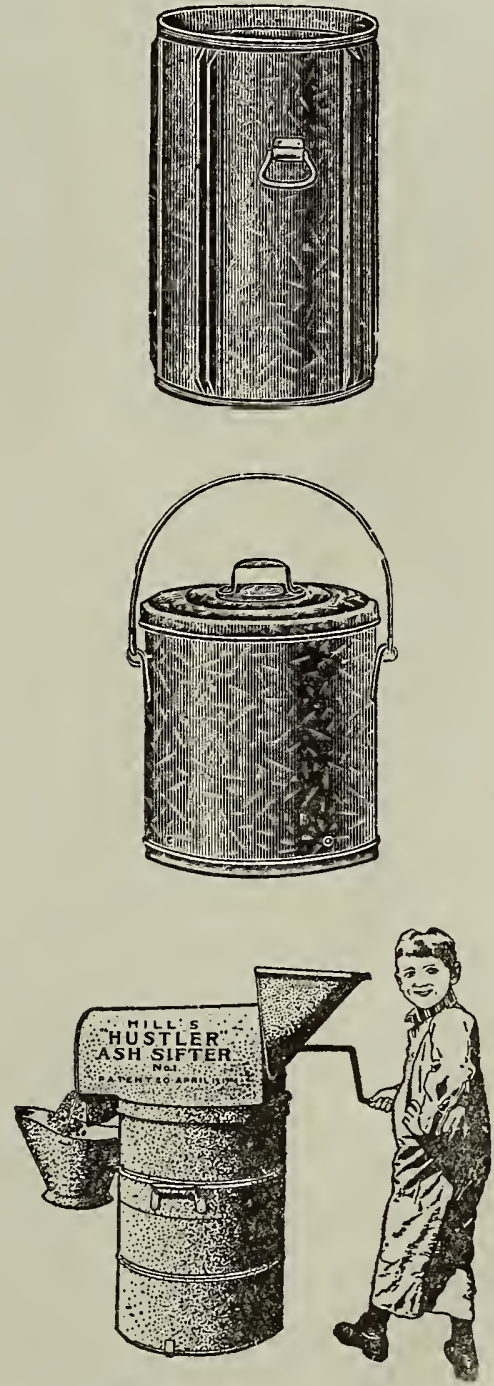


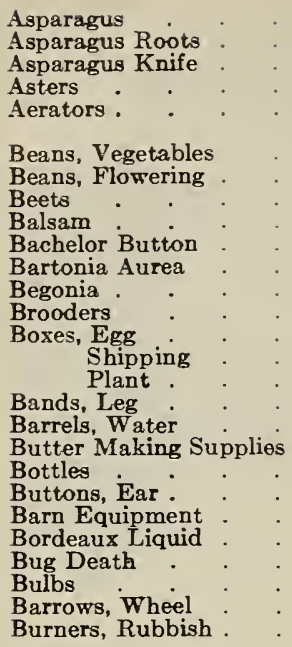

Cabbage

Cauliflower

Celery

Chervil

Chicory

Cress

Corn, Sweet

Cucumber

Carrot

Calendula

Canterbury Bells

Candytuft

Canna

Chrysanthemum

Cockscomb

Columbin

Cosmos

Cypress Vine

Coops

Cutters, Bone

Root

Crates

Cases, Egg

Conkey's Remedies and Foods

Charcoal

Carriers, Chick

Chicks, Day Old

Caponizing Sets

Cultivators

Coolers

Churn

Cans

Cleanser, Wyandotte

Cultures.

Clothes Dryers

Dandelion

Dahlis

Dairy Supplies

Egg Plant

Endive

Eggs, Hatching
Nest .

Florists' Vases

Flower Seeds

Forget-me-not

Feverfew

Foxglove

Fencing Wire

Feeders

Fountains

Fish Food

Feeds, Park \& Pollard

Fungicides

Fertilizers

Forks, Hay .

Grass Seeds

Grains

Gourds

Gloxinia

Garden Tools

Heliotrope

Hovers

Hopper.

C

E

$\mathrm{F}$

G
Page

Dr. Hess's Poultry and Stock Preparations

Hoes, Garden

Hose, Rubber

Household Supplies

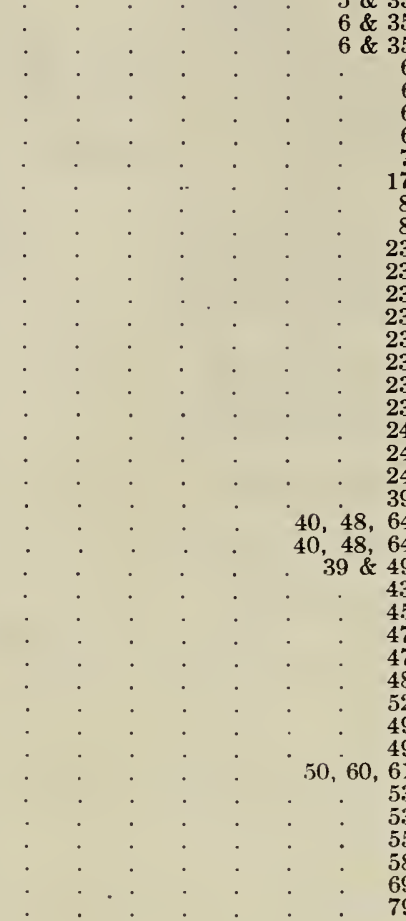

$\cdot \quad \cdot \quad \cdot \quad \cdot \quad \cdot \quad \cdot \quad \cdot \quad \begin{array}{r}94 \\ \cdot\end{array}$

$\cdot \quad \begin{array}{r}78 \\ 20-33\end{array}$

24

$40,45,70$

$41,42,45$

43
49
50

50

$65-68$
$68-69$
75
75

75

18,19

18, 19

25

59-61, 78

26

26
38

38
41,42
Incubators

Insecticides

Janitors' Supplies .

Kale

Kohl-Rabi

Knives, Pruning

Poultry

Labels, Garden and Pot

Lettuce.

Leek

Lawn Seed

Larkspur

Lobelia

Lawn Mowers

Melons

Mustard

Mushroom Spawn

Marigold

Mignonette

Milking Machines

Mowers

I

$\boldsymbol{J}$

$\mathbf{K}$

I.

tium

Nozzles, Hose

Okra

Oxalis

Plant Sprinklers

Pepper

Parsnip.

Pumpkin

Parsley

Peas, Vegetable

Plant Sweet

Punches

Pails

Pruning Shears

Pansy

Pinks

Primula

Poppies

Phlox

Pots, Flower

Poultry Supplie

Plant Sticks

Radish

Roofing

Remedies

Rat Killer

Reels

Rifles

Rakes

Raffia

Rollers, Garden

Rhubarb Roots

Spinach

Squash

Seeders

Seeding Table

Salvia

Salvia

Sprouters

Sheeting, Waterproof

Sulphur Candles

Scales

Separator

Stools

Sprayers

Scythe Snaths

Scythe Stones

Spades

Sickles

Tomato

Turnip

Thermometer

Tools, Garden and Farm

Trellises.

Tree Pruners

Water Glass

Wyandotte Cleansers

Watering Pots

Vegetable Seeds

M

$\mathbf{N}$

o

$\mathbf{R}$

S

$\mathbf{T}$
59, 60, 61, $\begin{array}{r}\text { Page } \\ 45,78 \\ 78 \\ 73 \\ 16\end{array}$

$65, \quad 68$

79

9
9
74
48

48

77

10

19

74

71,72

10

10

27

56

71,72

28
63

10

11
29

73

10

11

12,13

32,33

35

54
74

29, 30

24

30

30

36,50

13
47
47
48
73
75
75
76
73
35

14
14

59,74

59. 60,7 


\section{Fees for Money Orders drawn on Domestic Form}

Payable in the United States (which includes Guam, Mawaii, Porto Rico and Tutuila, Samoa); or payable in Bermuda, British Guiana, British Honduras, Canada, Canal Zone (Isthmus of Panama), Cuba, Newfoundland, at the United States Postal Agency at Shanghai (China), in the Philippine Islands, or the following islands in the West Indies: Antigua, Bahamas, Rarbados, Dominica, Grenada, Jamaica, Martinique, Montserrat, Nevis, St. Kitts, St. Lucia, St. Vincent, Trinidad and Tobago, and Virgin Islands.

$$
\begin{aligned}
& \text { For Orders From } \$ 0.01 \text { to } \$ 2.50 \quad \ldots . .3 \text { cents. } \\
& \text { From } \$ 2.51 \text { to } \$ 5.00 \quad \ldots . .5 \text { cents. } \\
& \text { From } \$ 5.01 \text { to } \$ 10.00 \quad \ldots . .88 \text { cents. } \\
& \text { From } \$ 10.01 \text { to } \$ 20.00 \quad \ldots . .10 \text { cents. } \\
& \text { From } \$ 20.01 \text { to } \$ 30.00 \quad \ldots . .12 \text { cents. } \\
& \text { From } \$ 30.01 \text { to } \$ 40.00 \quad \ldots . .15 \text { cents. } \\
& \text { From } \$ 10.01 \text { to } \$ 50.00 \quad \ldots . .18 \text { cents. } \\
& \text { From } \$ 50.01 \text { to } \$ 60.00 \quad \ldots . .20 \text { cents. } \\
& \text { From } \$ 60.01 \text { to } \$ 75.00 \quad \ldots . .255^{\circ} \text { cents. } \\
& \text { From } \$ 75.01 \text { to } \$ 100.00 \quad \ldots . .30 \text { cents. }
\end{aligned}
$$

Memoranda of Issuing Postmaster:

X'тқ.- The maximum amout for wbicb a single Money Order may he issued is $\$ 100$. When a larger sum is to be sent adlitiouil ()riters iuust be obtuined. Any number of Orders may be drawn on any Mouey (Order oftice on ang oue day.

A pplications must be preserved at the office of issue for three rears from date of issue.

(Emitron Feb., 1915.) 
(Form No. 6001)

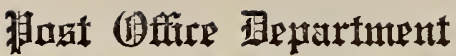

THIRD ASSISTANT POSTMASTER GENERAL DIVISION OF MONEY ORDERS

The Postmaster

will insert

\begin{tabular}{|l|l|}
\hline DOLLARS & CENTS \\
\hline & \\
\hline
\end{tabular}

bere

the effice drawn on, when the office named by

the remitter in the body of this application is not a Money Order Office.

Spaces above this line are for the Postmaster's record, to be filled in by him.

\section{Application for Domestic Money Order}

Spaces below to be filled in by purchaser, or, if necessary,

by another person for him

Amount

Dollars

Cents

Pay to
Order of ALLEN, STERLING \& LOTHROP

(Name of person or firm for whom order is intended)

$\left.\begin{array}{l}\text { Whose } \\ \text { Address }\end{array}\right\}$

49 EXCHANGE

$\left.\begin{array}{l}\text { Post } \\ \text { Office }\end{array}\right\}$

PORTLAND,

Street

\section{MAINE.}

State.

Sent by

Address )

$\left.\begin{array}{c}\text { of } \\ \text { sender }\end{array}\right\}$ No.

Street 


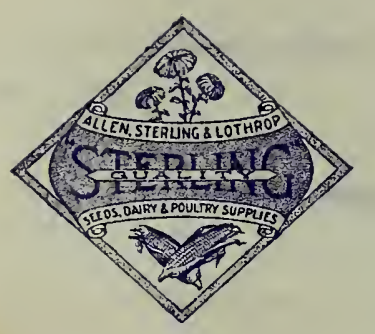

Amount Enclosed.

Name

\section{P.O. Address}

Street or

R. F. D.

State

\section{Express or Freight Station}

(If different from $P .0$.)

FROM

\section{ALLEN, STERLING \& LOTHROP}

49 Exchange Street

64 Market Street

:

Date

We give no warranty, express or implied, as to purity, description, quality, productiveness or any other matter of any seeds, bulbs or plants we send out, and we will not be in any way responsible for the crop. If the purchaser does not accept the goods on these terms, they are at once to be returned.

\begin{tabular}{l|ll} 
Quantity & NAME OF SEEDS
\end{tabular}




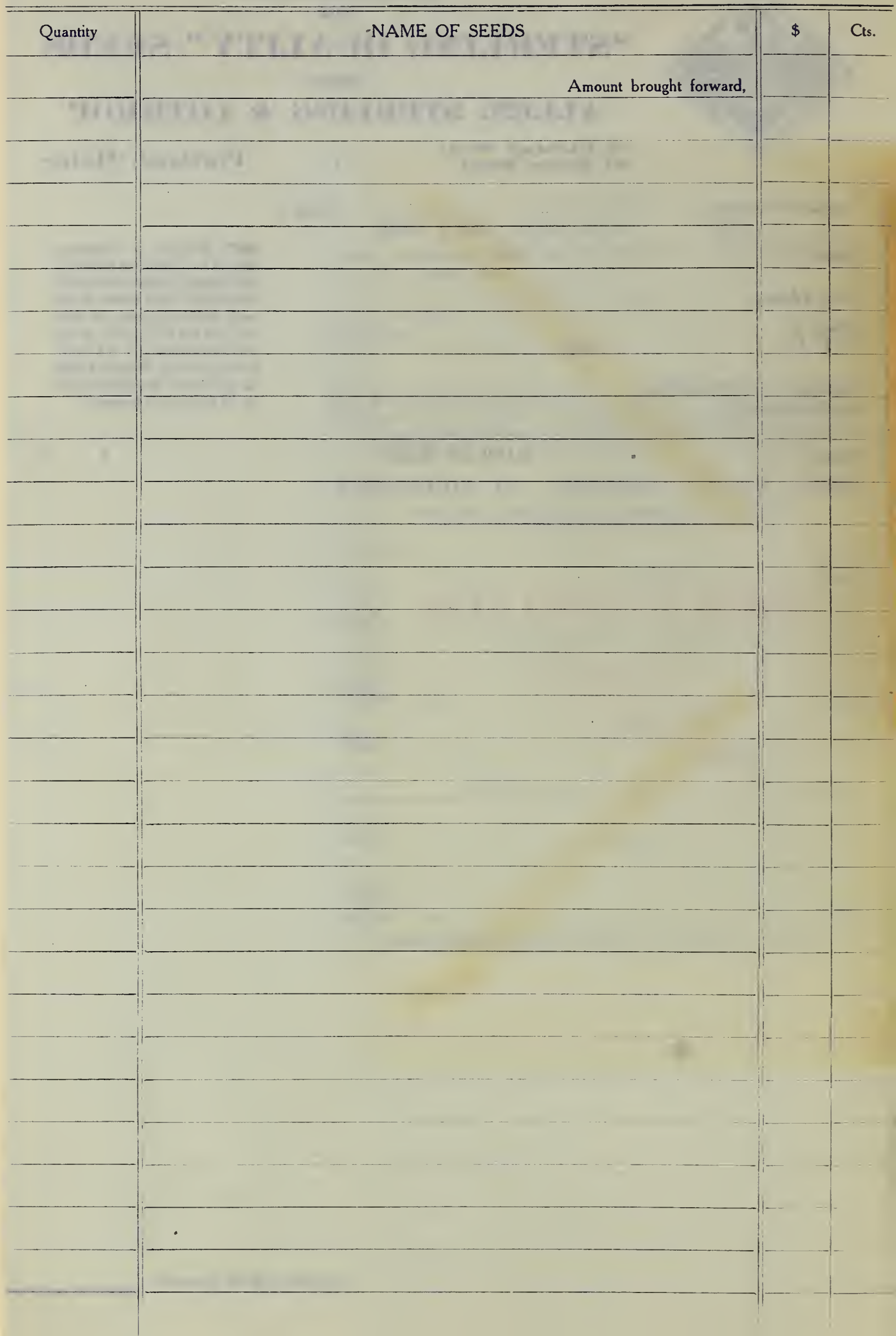




\section{Allen, Sterling \& Lothrop} "Sterling Quality" Seeds

\section{PORTLAND}

49 EXCHANGE ST. 



\section{Parcel Post Rates}

\begin{tabular}{|c|c|c|c|c|c|}
\hline & & & First Pound & $\begin{array}{c}\text { Each } \\
\text { Addultlonal } \\
\text { Pound }\end{array}$ & Welght LImilt : \\
\hline Portland and Rural Delivery & & Local & 5c. & $\frac{1}{3} c_{.}$ & 50 lbs. \\
\hline Within 150 miles & Zor & and 2 & 5c. & 1c. & 50 lbs. \\
\hline 150 to 300 miles & 6 & 3 & 6c. & 2c. & 20 lbs. \\
\hline 300 to 60066 & 66 & 4 & 7c. & $4 c$. & 20 lbs. \\
\hline 600 to 1,000 & 66 & 5 & $8 c$. & $6 c$. & 20 lbs. \\
\hline 1,000 to 1,400 & 6 & 6 & 9c. & 8c. & 20 lbs. \\
\hline 1,400 to 1,800 & 66 & 7 & 11c. & 10c. & 20 lbs. \\
\hline 1,800 miles and over & 6 & $\overline{8}$ & 12c. & 12c. & 20 lbs. \\
\hline
\end{tabular}

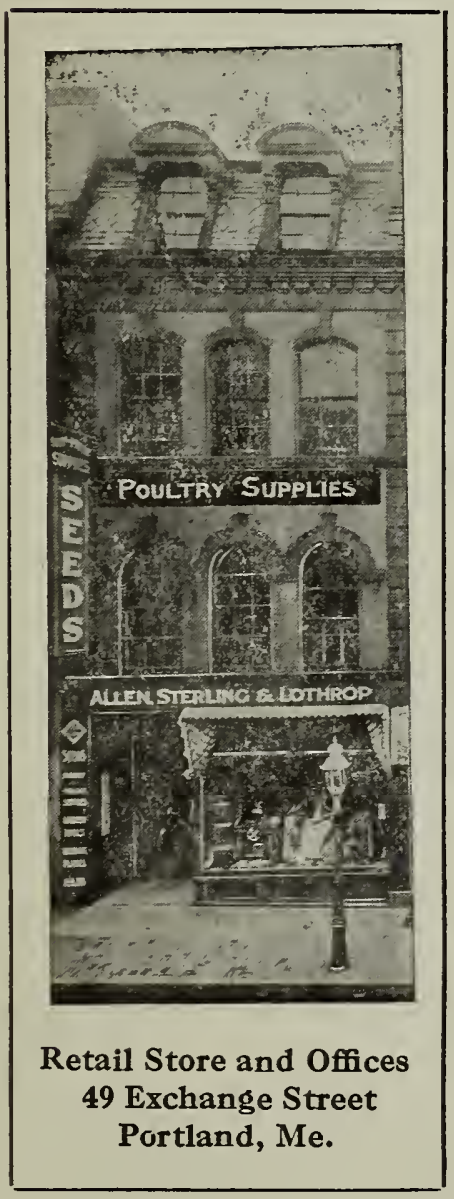

\section{The Latch String is Always Out to Our Customers}

We extend to you a most cordial invitation to make our store your headquarters when in Portland. Come in real often-see the new articles which we are constantly offering (we like to show them whether you purchase or not) use our telephone-leave your bundles with us-in fact, just COME IN and make yourselves at home.

ALLEN, STERLING \& LOTHROP. 


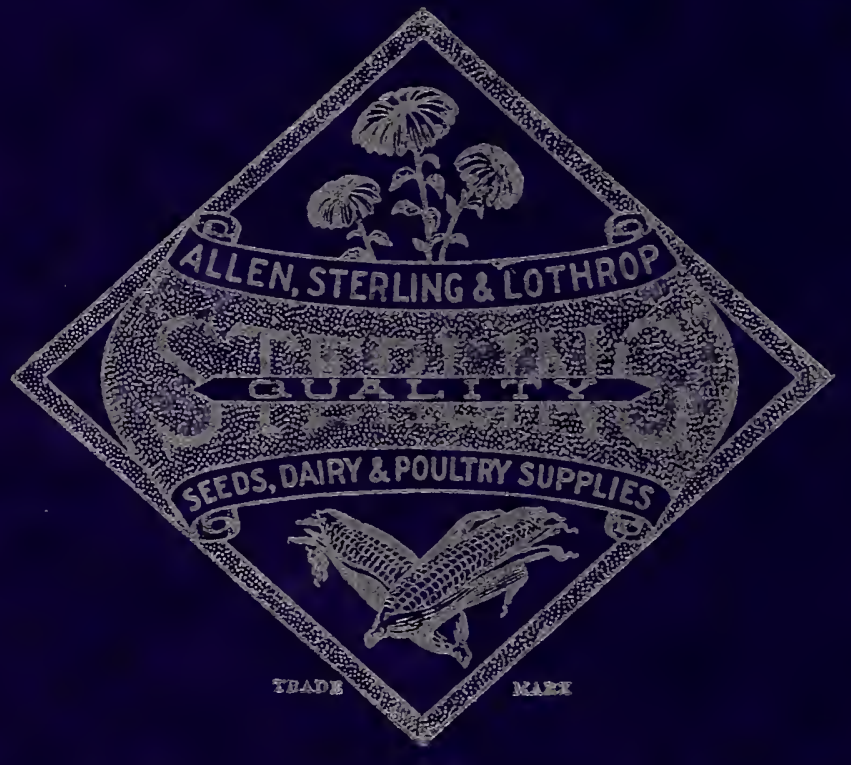

